\title{
Micro Cooling, Heating, and Power (Micro-CHP) and Bio-Fuel Center Mississippi State University
}

\section{THERMOECONOMIC MODELING OF MICRO-CHP (MICRO-COOLING, HEATING, AND POWER) FOR SMALL COMMERCIAL APPLICATIONS}

\section{INTRODUCTION}

The term CHP (Cooling, Heating, and Power) describes all electrical power generation systems that utilize recoverable waste heat for space heating, cooling, and domestic hot water purposes. CHP has proven beneficial in many large-scale applications (hospitals, etc.) by providing higher quality, more reliable power while generating high total energy efficiencies. Applying CHP to small-scale applications is an attractive option because of a large potential market.

Micro-CHP encompasses all systems in the range of $15 \mathrm{~kW}$ to $35 \mathrm{~kW}$ of electrical production or less. These systems range from single family homes to small apartment complexes to small office buildings. In a typical micro-CHP system, electricity is generated on-site from the combustion of a fuel source in an electrical generation set (prime mover and generator). This combustion produces recoverable heat in the form of heated engine coolant and high temperature exhaust. The use of the recoverable thermal energy for space heating and cooling purposes is the driving factor behind the increased overall energy usage from conventional power generation systems.

Feasibility studies for the use of micro-CHP in Europe began in the early 1990s and since that time, several micro-CHP technologies have been developed and investigated. However, since micro-CHP is viewed differently in Europe and because differences in markets and climatic conditions exist in Europe, the technologies developed and used in Europe may not be directly applicable to the U.S. market [1-3]. Common challenges have been identified in the European market. Three major obstacles currently existing to market penetration are cost, the requirement for market transformation, and developing the necessary maintenance skill base [4]. Some of these challenges also exist for the U.S. market.

The use of micro-CHP systems has many advantages as well as disadvantages. MicroCHP systems increase efficiency of fuel. Approximately $85 \%$ of the energy put into a system is used for either electrical power or heating and cooling purposes. A traditional power plant will generally only convert $30 \%$ of the energy put into the system into electrical energy. The other $70 \%$ may be released into the atmosphere as waste heat. One major disadvantage of micro-CHP systems is the high initial costs of the equipment that make up the systems. Another advantage that micro-CHP systems have over traditional central power plants is the difference in energy costs. The only energy cost involved in a micro-CHP system is the cost to supply the fuel necessary to run the prime mover, whereas, in a traditional system the energy consumer has to pay monthly power demand and electrical energy usage charges for all electrical power. 
Jalalzadeh-Azar et al. [5] performed an evaluation based on a nondimensional analysis of energy cost and primary energy consumption of CHP systems for office buildings using two CHP scenarios for an office building in three different geographical locations. He used gas-fired micro-turbine generators in all cases to provide on-line electricity and thermal energy for the building. He reported the effect of power generator efficiency on the total primary energy consumption and cost.

Initially, most micro-CHP systems will likely be designed as constant-power output or base-load systems. This implies that at some point the power requirement will not be met, or that the requirement will be exceeded. Realistically, both cases will occur within a 24-hour period. For example, in the United States, the base electrical load for the average home is approximately $2 \mathrm{~kW}$ while the peak electrical demand is slightly over $4 \mathrm{~kW}$. If a $3 \mathrm{kWe}$ microCHP system were installed in this situation, part of the time more energy will be provided than could be used and for a portion of the time more energy will be required than could be provided. Jalalzadeh-Azar [6] investigated this situation and presented a comparison of electrical- and thermal-load-following CHP systems. In his investigation he included in a parametric analysis addressing the influence of the subsystem efficiencies on the total primary energy consumption as well as an economic analysis of these systems. He found that an increase in the efficiencies of the on-site power generation and electrical equipment reduced the total monthly import of electricity.

A methodology for calculating performance characteristics of different micro-CHP system components will be introduced in this article. Thermodynamic cycles are used to model each individual prime mover. The prime movers modeled in this article are a spark-ignition internal combustion engine (Otto cycle) and a diesel engine (Diesel cycle). Calculations for heat exchanger, absorption chiller, and boiler modeling are also presented. The individual component models are then linked together to calculate total system performance values.

Performance characteristics that will be observed for each system include maximum fuel flow rate, total monthly fuel consumption, and system energy (electrical, thermal, and total) efficiencies. Also, whether or not both the required electrical and thermal loads can sufficiently be accounted for within the system specifications is observed.

Case study data for various micro-CHP system configurations have been discussed and compared. Comparisons are made of the different prime mover/fuel combinations. Also, microCHP monthly energy cost results are compared for each system configuration to conventional monthly utility costs for equivalent monthly building power, heating, and cooling requirements.

\section{NOMENCLATURE}

$\begin{array}{ll}A F & \text { air-fuel ratio } \\ c_{p} & \text { specific heat at constant pressure }(\mathrm{kJ} / \mathrm{kg}-\mathrm{K}) \\ c_{v} & \text { specific heat at constant volume }(\mathrm{kJ} / \mathrm{kg}-\mathrm{K}) \\ C & \text { cost } \\ C O P & \text { coefficient of performance } \\ E & \text { electricity }(\mathrm{kJ}) \\ \dot{E} & \text { electrical power }(\mathrm{kW}) \\ E_{e, \text { usage }} & \text { monthly electrical usage for the lighting and office equipment } \\ E_{\text {hc,usage }} & \text { monthly electrical usage required to power an electric heat pump }\end{array}$




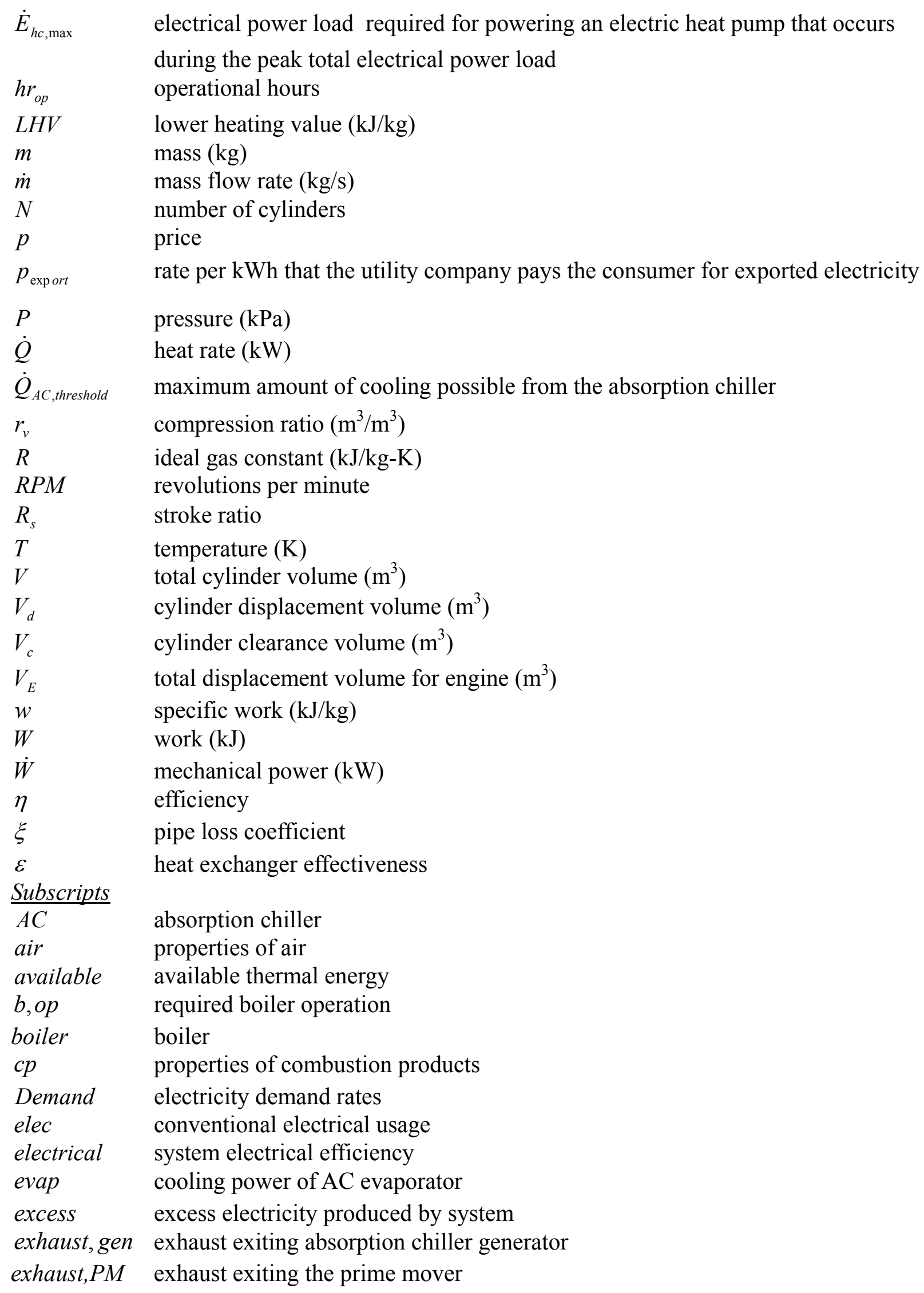




$\begin{array}{ll}\text { fuel } & \text { properties or flow rates of fuel } \\ \text { gen } & \text { generator } \\ \text { generated } & \text { electricity generated by micro CHP system } \\ \text { max } & \text { maximum } \\ \text { mech } & \text { mechanical work or power } \\ \text { mix } & \text { flow rates or mass values of mixture } \\ \text { net } & \text { net specific work or power } \\ \text { ng } & \text { natural gas } \\ T & \text { prime mover thermal efficiency } \\ \text { thermal } & \text { system thermal efficiency } \\ \text { total } & \text { system total efficiency } \\ \text { usage } & \text { electrical usage requirements } \\ \text { water } & \text { properties or flow rates of water } \\ \text { w,in,HX } & \text { water entering heat exchanger } \\ w, \text { in }, \text { gen } & \text { water entering the absorption chiller generator } \\ \text { w,out,gen } & \text { water exiting absorption chiller generator } \\ \text { w,outHX } & \text { water exiting heat exchanger }\end{array}$

\section{ANALYSIS}

To evaluate the performance of CHP systems, thermodynamic models of the different components have to be developed. Although the analysis of simplified thermodynamic models generally leads only to qualitative conclusion about the system performance, these models allow to evaluate how the changes in operating parameters affect the actual system performance. Also, different parameters can be evaluated to improve the system overall performance by utilizing these models. An illustration of the micro-CHP system analyzed in this paper is shown in Figure 1. The equations used to model each individual component are presented in this section. 


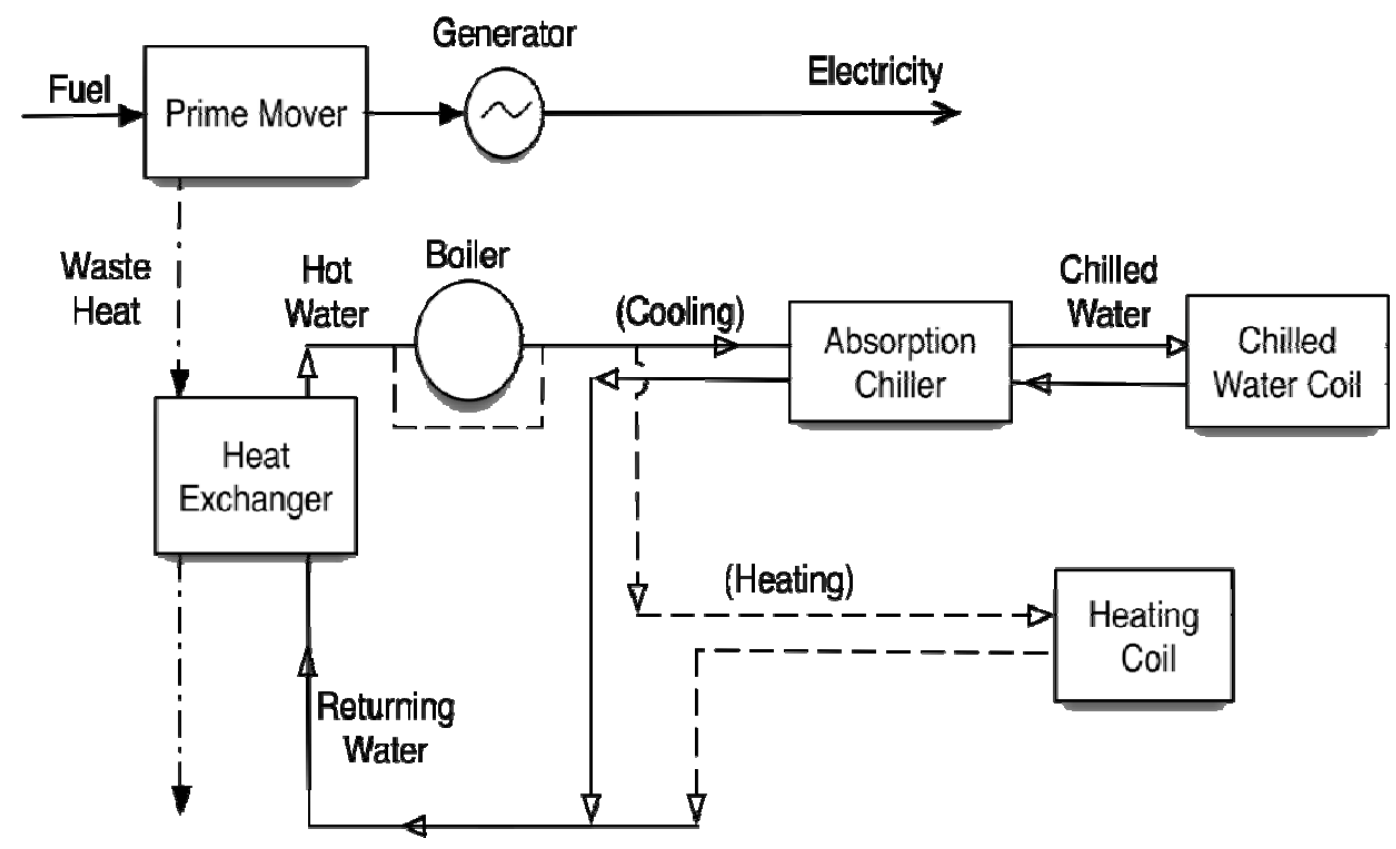

Figure 1. Micro-CHP Case Study Schematic

\section{$\underline{\text { Electric Power }}$}

In a micro-CHP system, electricity is supplied to a specific building or buildings by a generator. This electricity is used for lighting, home, or office equipment. In this investigation, the generator is specifically the device that converts mechanical shaft energy from the prime mover into electrical energy supplied to the building. This definition is given in order to separate the two devices for modeling purposes. Generally, prime movers and generators are packaged and sold together as generator sets. If the micro-CHP system is to be used as the sole electrical power source, then the prime mover/generator set has to be rated for at least the peak electrical power demand of the building. If the primary generator set is not able to produce the requirement for the maximum electrical power load, additional prime movers can be added to the system to account for any intermediate or peak electrical power loads. Electricity can also be imported from the grid to account for any system electricity production shortages.

Some of the important parameters that have to be considered for CHP applications are the peak electrical demand and the total electrical energy usage. The peak electrical demand of a system is the maximum electrical power load that is required for each month. This quantity defines a load at an instantaneous point in time. The total electrical energy usage is the total amount of electricity that is required for a system over a time period.

If the system is electrical load-following, then all of the system outputs will depend on the continuously changing required electrical load of the building. Each time interval (time intervals are dependent upon the level of accuracy needed) would have to have its own separate calculations and performance outputs. If the time intervals were small, these calculations would prove to be more time-consuming than is necessary in the scope of this research. 
Generally residential heating and cooling load requirements are much larger than required electrical loads. Therefore, when following the electrical load, the prime mover may not be able to produce enough recoverable thermal energy to satisfy the heating and cooling load requirements.

For the purposes of comparing how different prime movers affect a system's performance, each of the systems will be modeled as if they were operating at constant maximum power. Therefore, there will potentially be excess electricity that can either be exported to the grid or stored in a battery. In either case, the electrical energy efficiency calculation for the entire system must include this exported or stored electricity. The total generated electricity and total excess electricity for a month are calculated in Equations (1) and (2), respectively.

$$
\begin{aligned}
& E_{\text {generated }}=\dot{E}_{\text {max }} \cdot h r_{o p} \\
& E_{\text {excess }}=E_{\text {generated }}-E_{\text {usage }}
\end{aligned}
$$

where $E_{\text {generated }}$ is the total electricity generated by the prime mover/generator for the month, $\dot{E}_{\max }$ is the constant maximum electrical power output of the generator, $h r_{o p}$ is the operational hours, $E_{\text {excess }}$ is the monthly excess electricity produced, and $E_{\text {usage }}$ is the total monthly electrical usage for the building.

Energy losses occur in a generator during the transformation of mechanical shaft energy into electricity. These losses are accounted for using the generator efficiency value, which is defined in Equation (3) as the ratio of electrical power produced by the generator to the mechanical shaft power produced by the prime mover and supplied to the generator.

$$
\eta_{\text {gen }}=\frac{\dot{E}_{\text {generated }}}{\dot{W}_{\text {mech }}}
$$

$\dot{W}_{\text {mech }}$ is the mechanical shaft power produced by the prime mover, and $\dot{E}_{\text {generated }}$ is the electrical power output of the generator.

\section{Thermodynamic Cycle Assumptions}

The models described in this paper use thermodynamic cycles to model the different prime movers. The models are better suited for comparing the effects of changing different components and variables and finding the trends that may lead to optimum system performance than providing exact system performance quantities. While the numerical values that are obtained are used to compare different configurations, the actual system processes may result in performance quantities that are somehow different. Assumptions made throughout the models for thermodynamic cycles include:

- Either air or an air/fuel mixture is the working fluid and is modeled as an ideal gas.

- Heat transfer from an external source replaces the combustion process in the Otto and Diesel cycles.

- Heat rejection to the surroundings replaces the exhaust processes in the Otto and Diesel cycles. 
Important parameters such as: boiler efficiency, heat exchanger effectiveness, chiller coefficient of performance (COP), and pipe loss coefficient are used throughout the calculations to account for and irreversibilities that may occur in the actual process.

\section{Prime Movers}

This investigation includes two internal combustion engine prime movers: a sparkignition combustion engine and a compression-ignition combustion engine. Various micro-CHP systems and on-site power generation systems that are powered by internal combustion engines are currently available for the consumer. Drawbacks of using internal combustion engines include higher noise levels, frequent maintenance, and higher environmentally harmful emissions [9]. Internal combustion engines are separated into two categories describing the different fuel combustion processes. In a spark-ignition combustion engine, an air-fuel mixture enters the cylinder, and the mixture is compressed to a temperature below the fuel auto-ignition temperature. A spark then ignites the mixture in the combustion process. In a compressionignition combustion engine, air is compressed in the cylinder to a temperature higher than the fuel auto-ignition temperature, and combustion takes place when the fuel is injected into the cylinder.

- Spark-Ignition Combustion Engine

Spark-ignition combustion engines are modeled using the processes of the Otto cycle. In the Otto cycle, the air-fuel mixture inside the cylinder is initially adiabatically compressed by the engine piston. A spark from the spark plug then ignites the compressed mixture and causes the pressure inside the cylinder to rise in the constant volume process. The combustion products are then adiabatically expanded in the power stroke of the piston. The power stroke creates the mechanical work output. The pressure-specific volume and temperature-entropy diagrams for the Otto cycle are depicted in Figure 2a.

The work into and out of the system per unit mass during the assumed isentropic compression and expansion processes are both equal to the changes in the system internal energies. These values are calculated with the following Equations (4) and (5) [10]

$$
\begin{aligned}
& w_{12}=c_{v, \text { air }} \cdot\left(T_{1}-T_{2}\right) \\
& w_{34}=c_{v, \text { air }} \cdot\left(T_{3}-T_{4}\right)
\end{aligned}
$$

where $c_{v, \text { air }}$ is the specific heat of air, $T_{1}$ is the inlet temperature of the engine, $T_{2}$ is the fluid temperature after compression, $T_{3}$ is the maximum cycle temperature after combustion, $T_{4}$ is the exhaust temperature of the combustion products, and $r_{v}$ is the compression ratio.

The net work output per unit mass of the system is calculated by the addition of both the specific work values of the compression and power strokes given in Equation (6).

$$
w_{\text {net }}=w_{12}+w_{34}
$$

An important quantity in modeling an internal combustion engine is the amount of airfuel mixture that is present in the cylinder during the cycle. Using the ideal gas law, the required mass of the air-fuel mixture can be calculated as [10] 


$$
m_{m i x}=\frac{P_{1} \cdot V}{R \cdot T_{1}}
$$

where $T_{1}$ and $P_{1}$ are the inlet conditions of the air into the cylinder, $R$ is the ideal gas constant, and $V$ is the total volume of the cylinder. The total volume of the cylinder, $V$, is found from Equation (8) when the total displacement volume for the entire engine, $V_{E}$, is known. Equation (9) calculates the displacement volume of each cylinder from the known total displacement volume.

$$
V=V_{d}+V_{c}
$$

where

$$
V_{d}=\frac{V_{E}}{N}
$$

where $N$ is the number of cylinders in the engine, and $V_{c}$ can be solved using Equation (10) for a known compression ratio, $r_{v}$.

$$
r_{v}=\frac{V_{c}+V_{d}}{V_{c}}
$$

The total work output of the engine for each cycle of each cylinder is given in Equation (11),

$$
W_{n e t}=m_{m i x} \cdot w_{n e t}
$$

and the total mechanical power output of the engine is calculated using Equation (12).

$$
\dot{W}_{\text {mech }}=W_{n e t} \cdot N \cdot \frac{R P M}{R_{S}}
$$

where $R P M$ is the speed of the engine and $R_{S}$ is the number of revolutions of the engine to complete each cycle. For a 4 -stroke engine, $R_{S}=2$.

The Otto cycle constant volume heat input per cylinder per cycle can be calculated using either Equation (13) or Equation (14) [10]. The three unknowns that are possible for the two Equations (13) and (14) are the air-fuel ratio, $A F$, the maximum cycle temperature, $T_{3}$, and the mass of the fuel present in each cylinder for each cycle, $m_{f}$. One of these values have to be either known or assumed to solve for the other two unknowns.

$$
\begin{gathered}
Q_{23}=Q_{h}=m_{f} \cdot(A F+1) \cdot c_{v, \text { air }} \cdot\left(T_{3}-T_{2}\right) \\
Q_{23}=Q_{h}=m_{f} \cdot L H V
\end{gathered}
$$

where $m_{f}$ is the mass of fuel mixed with air in each cylinder for each cycle. The heat rejected in the Otto cycle (representing the exhaust process) is

$$
Q_{l}=Q_{41}=c_{v, \text { air }} \cdot\left(m_{\text {mix }}\right) \cdot\left(T_{1}-T_{4}\right)
$$


Equations (13), (14), and (15) give the heat addition and heat rejection terms of the cycle in terms of $\mathrm{kJ} /$ cyl-cycle. In order to find approximate total heat addition or rejection rates, the heat inputs and outputs of Equations (13)-(15) must be converted as in the following Equations (16) and (17). In Equations (16) and (17) The number of cycles per minute and the total number of cylinders of the engine are used to calculate an approximate heat addition or rejection "rate."

$$
\begin{gathered}
\dot{Q}_{23}=\dot{Q}_{h}=Q_{h} \cdot N \cdot \frac{R P M}{R_{S}} \\
\dot{Q}_{l}=\dot{Q}_{41}=Q_{l} \cdot N \cdot \frac{R P M}{R_{S}}
\end{gathered}
$$

The thermal efficiency of the cycle is calculated in Equation (18).

$$
\eta_{T}=\frac{W_{n e t}}{Q_{h}}
$$

\section{-Compression-Ignition Combustion Engine}

A compression-ignition, or diesel, engine can be modeled by the principles of the Diesel cycle. The cycle is broken up into four processes:

$1-2$ : adiabatic compression

$2-3$ : constant pressure heat addition

3 - 4: adiabatic expansion

$4-1$ : constant volume heat rejection

Figure $2 \mathrm{~b}$ depicts the pressure-specific volume and temperature-entropy diagrams for the Diesel cycle.

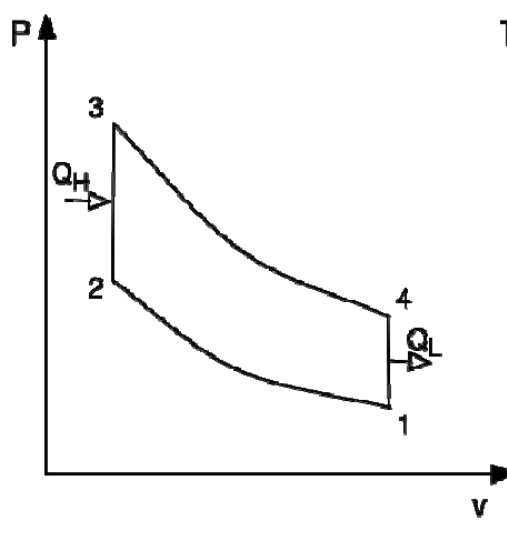

(i)

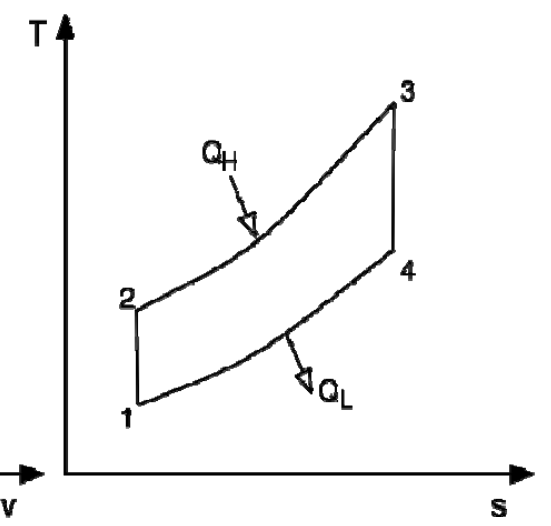

(ii)

(a) 


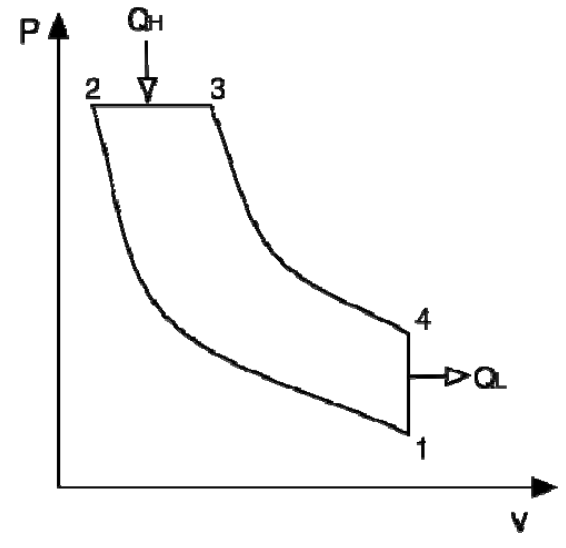

(iii)

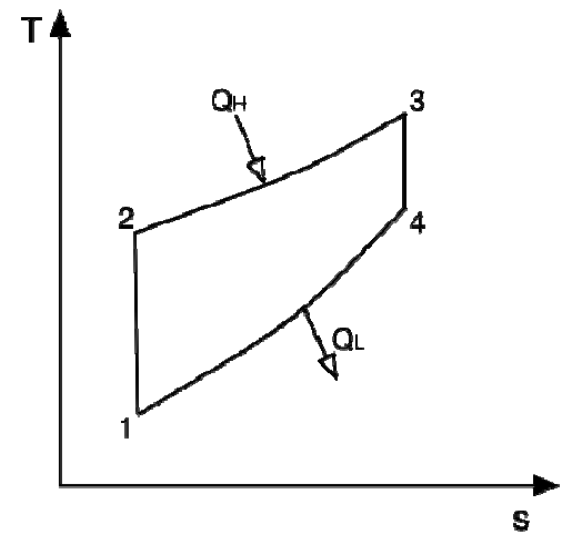

(iv)

(b)

Figure 2. Prime movers: (a) Otto Cycle: i) Pressure-Specific Volume Diagram, ii) TemperatureEntropy Diagram, (b) Diesel Cycle: iii) Pressure-Specific Volume Diagram, iv) TemperatureEntropy Diagram

All of the equations used for the spark-ignition model are used to model the diesel engine except for the differences in the combustion process. The equation for the total heat rate addition representing the combustion process is shown as Equation (19).

$$
\dot{Q}_{23}=\dot{Q}_{h}=c_{p} \cdot\left(m_{\text {air }}+m_{\text {fuel }}\right) \cdot\left(T_{2}-T_{3}\right) \cdot N \cdot \frac{R P M}{R_{S}}
$$

where $T_{2}$ and $T_{3}$ are the temperatures at the beginning and end of the combustion process, respectively. Work is also done during the combustion process and is represented from the First Law as the difference of the change in enthalpy and change in internal energies from State 2 to State 3. The specific work done during the combustion process, $w_{23}$, is calculated in Equation (20) and also included in the equation for the net specific work of the cycle [10].

$$
\left.w_{23}=\boldsymbol{c}_{p} \cdot\left(T_{3}-T_{2}\right)\right\rfloor\left[c_{v} \cdot\left(T_{3}-T_{2}\right)\right]
$$

Also, fuel is not present during the initial compression process which leads to the following calculation in Equation (21) for net mechanical work of the cycle.

$$
W_{\text {net }}=m_{\text {air }} \cdot w_{12}+m_{\text {mix }} \cdot\left(w_{23}+w_{34}\right)
$$

\section{Waste Heat Utilization}

The maximum available heat for input to either a direct-fired absorption chiller or an exhaust-water heat exchanger is found from the heat rejection rate value found from each of the thermodynamic cycles: 


$$
\dot{Q}_{\text {available }}=\xi \cdot \dot{Q}_{l}
$$

where $\xi$ is the pipe loss coefficient and is always less than 1 .

The available heat rate for a water-fired absorption chiller takes into account any energy losses that occur in the exhaust-water heat exchanger as in Equation (23) [11]

$$
\dot{Q}_{A C, \text { available }}=\varepsilon \cdot \dot{Q}_{\text {available }}
$$

where $\varepsilon$ is the heat exchanger effectiveness.

An absorption chiller has a set minimum inlet water temperature into the generator for operation. The mass flow rate of water required to achieve the inlet water temperature required by the absorption chiller generator can be determined as follows:

$$
\dot{m}_{\text {water }}=\frac{\dot{Q}_{\text {available }}}{c_{p w a t e r}\left(T_{w, o u t, H E}-T_{w, i n, H E}\right)}
$$

where $T_{w, o u t, H X}$ and $T_{w, i n, H X}$ are the exit and inlet water temperatures of the heat exchanger, respectively, and $c_{\text {pwater }}$ is the specific heat of the water.

\section{Absorption Chiller}

The available heat modeled by a heat rejection process from the prime mover drives the absorption chiller. The heated water or exhaust enters the absorption chiller generator, which acts as a heat exchanger and evaporates the working fluid out of the generator solution. With a known outlet temperature of the exhaust or water from the absorption chiller generator, the heat rate dissipated in the generator is the difference in the heat rate available from the exhaust or water heat rate still available in ambient conditions after leaving the generator. The heat rate dissipated in the generator is calculated using either Equations (25) or (26) for direct-fired or water-fired absorption chillers, respectively.

$$
\begin{aligned}
& \dot{Q}_{\text {gen }}=\dot{m}_{\text {mix }} \cdot c_{p, c p}\left(T_{\text {exhaust,gen }}-T_{\text {exhaust }, P M}\right) \\
& \dot{Q}_{\text {gen }}=\dot{m}_{\text {water }} \cdot c_{p w a t e r} \cdot\left(T_{w, \text { in, gen }}-T_{w, \text { out }, \text { gen }}\right)
\end{aligned}
$$

$T_{\text {exhaust, gen }}$ is the temperature of the exhaust exiting the absorption chiller generator and $T_{\text {exhaust }, P M}$ is the temperature of the exhaust exiting the prime mover. $T_{w, \text { in }, \text { gen }}$ and $T_{w, \text { out,gen }}$ are the temperatures of the water entering and exiting the absorption chiller generator, respectively.

The coefficient of performance ( $C O P$ ) of an absorption chiller when the pump work of the unit is neglected is the ratio of thermal power (cooling) produced by the absorption chiller evaporator to the thermal power required to drive the absorption chiller generator. The $C O P$ is defined in Equation (27) when pump work is neglected [12]

$$
C O P=\frac{\dot{Q}_{\text {evap }}}{\dot{Q}_{\text {gen }}}
$$

where $\dot{Q}_{\text {evap }}$ is the cooling power output of the absorption chiller evaporator. 


\section{System Efficiencies}

Three different efficiencies that represent important system characteristic values can be calculated for micro-CHP systems: the system thermal efficiency, the system electrical efficiency, and the system total energy efficiency. These three efficiencies give a quantitative description of how much and for what purposes the energy (in the form of combustible fuel) being supplied to the system is used. Energy in a micro CHP system is lost in the form of low temperature heat within exhaust and as radiation and convection from all components [8].

The system thermal efficiency is the ratio of the total usable thermal energy (in the form of heating and cooling) produced by the system to the total energy supplied to the system. This relationship is described in Equation (28) as

$$
\eta_{\text {thermal }}=\frac{\dot{Q}_{\text {thermal }}}{\dot{Q}_{\text {in }}}
$$

The system electrical efficiency is the ratio of the total electrical energy (electrical power) produced by the system to the total energy supplied to the system and it can be expressed as:

$$
\eta_{\text {electrical }}=\frac{\dot{W}_{\text {elec }}}{\dot{Q}_{\text {in }}}
$$

In both Equations (28) and (29) $\dot{Q}_{\text {in }}$ can be calculated by finding the sum of $\dot{Q}_{h}$ from either Equation (16) or (19) for the cases of the spark-ignition internal combustion engine and diesel engine, respectively and $\dot{Q}_{\text {boiler }}$ from Equation (32). The total system efficiency is the ratio of the total usable energy produced by the system to the total energy supplied to the system. This value is found by adding the system electrical efficiency and the system thermal efficiency as follows:

$$
\eta_{\text {total }}=\eta_{\text {electrical }}+\eta_{\text {thermal }}=\frac{\dot{Q}_{\text {thermal }}+\dot{W}_{\text {elec }}}{\dot{Q}_{\text {in }}}
$$

\section{Required Fuel Flow Rates}

A primary goal of each model is to determine how much fuel is required to run the microCHP system. The mass of the fuel required during the combustion process to produce certain power at specific engine speeds can be determined as

$$
\dot{m}_{\text {fuel }}=\frac{\dot{Q}_{h}}{L H V}
$$

If the prime mover is not able to produce enough recoverable thermal energy to account for the space heating or cooling loads then a boiler may be necessary. The amount of fuel energy input required for a natural gas-fired boiler can be calculated by Equation (32) as

$$
\dot{Q}_{\text {boiler }}=\frac{\dot{Q}_{\text {req }}}{\eta_{\text {boiler }}}
$$


where $\eta_{\text {boiler }}$ is the boiler efficiency and the required boiler thermal energy output for heating or cooling, $\dot{Q}_{\text {req }}$, is calculated by Equation (40) or (41).

$$
\begin{aligned}
& \dot{Q}_{\text {req }}=\dot{Q}_{\text {heat }}-\dot{Q}_{\text {available }} \\
& \dot{Q}_{\text {req }}=\dot{Q}_{\text {cool }}-\dot{Q}_{A C \text {,threshold }}
\end{aligned}
$$

$\dot{Q}_{A C, \text { threshold }}$ is the maximum amount of cooling possible from the absorption chiller for the previously determined amount of heat rejected from the prime mover.

\section{Economic Comparison}

The costs of implementing a micro-CHP system include capital costs of equipment, installation costs, and ongoing maintenance and fuel costs. The driving factor for the economic feasibility of a micro-CHP system is whether or not the energy savings of the system can payback the initial and installation costs of micro-CHP components in a short period of time. The energy savings discussed in this section are the monthly differences between the net energy costs of the micro-CHP system and the energy costs of using conventional central power plant electricity for cooling, heating, and power. The only energy cost involved in running a micro CHP system is the cost to supply the fuel necessary to run the prime mover; whereas, in a traditional system, the consumer has to pay monthly power demand and electrical energy usage charges for all electrical power. On top of these charges, the consumer may also have to pay monthly natural gas or propane charges depending on whether or not these are needed by the consumer for heating purposes.

To fully describe the cost analysis comparison of using a micro-CHP system versus using conventional electricity production, an in-depth economic payback analysis would have to be done with a known initial and installation cost and periodic maintenance costs. The focus of this research is only to observe the different monthly energy input savings that can be obtained by different prime movers. Therefore, only monthly net energy costs will be discussed in this section.

\section{Conventional Electricity Production Costs}

If an office is powered, heated, and cooled with conventional electricity (electric heat pump) from a centrally-located power plant, monthly electricity costs are present. Monthly electricity costs are calculated using two monthly charges: energy consumption and demand. The monthly electrical energy charge is the cost of electrical usage in kilowatt-hours. The monthly electrical demand charge is the price that is charged for the maximum electrical load, expressed in $\mathrm{kW}$. The cost of electricity for conventional electric power along with an electric heat pump for heating and cooling purpose can be calculated as

$$
C_{\text {elec }}=E_{e, \text { usage }} \cdot p_{\text {elec }}+E_{h c, \text { usage }} \cdot p_{\text {elec }}+\dot{E}_{e, \text { max }} \cdot C_{\text {Demand }}+\dot{E}_{h c \text {, max }} \cdot C_{\text {Demand }}
$$

where $E_{e, \text { usage }}$ is the monthly electrical usage for the lighting and office equipment, $E_{h c, \text { usage }}$ is the monthly electrical usage required to power an electric heat pump, $\dot{E}_{\max }$ is the electrical power load for lighting and office equipment that occurs during the peak total electrical power load, $\dot{E}_{h c, \max }$ is the electrical power load required for powering an electric heat pump that occurs 
during the peak total electrical power load, $p_{\text {elec }}$ is the usage rate for electricity, and $C_{\text {Demand }}$ is the demand cost of the electricity per $\mathrm{kW}$.

\section{Micro-CHP Costs}

The only energy cost associated with the use of a micro-CHP system is the cost of supplying fuel to the prime mover and the boiler, if a boiler is necessary. Equation (36) gives the calculation for monthly micro CHP energy cost.

$$
C_{\text {Fuel }}=\dot{m}_{\text {fuel }} \cdot L H V \cdot p_{\text {fuel }} \cdot h r_{o p}+\dot{Q}_{\text {boiler }} \cdot p_{n g} \cdot h r_{b, o p}
$$

where $p_{\text {fuel }}$ is the price of fuel into the prime mover per unit of fuel energy, $p_{n g}$ is the price of natural gas per unit of fuel energy, and $h r_{b, o p}$ is the number of full-load hours required of boiler operation.

Excess electricity that is exported to the grid must also be taken into consideration, when calculating monthly energy costs. Therefore, the net energy cost of using a micro-CHP system is calculated using Equation (37).

$$
C_{\text {net }}=C_{\text {Fuel }}-E_{\text {excess }} \cdot p_{\text {exp ort }}
$$

where $p_{\text {export }}$ is the rate per $\mathrm{kWh}$ that the utility company pays the consumer for exported electricity.

The individual models discussed in this chapter were linked together to create a microCHP model using Microsoft Excel software. System performance outputs of the model include prime mover monthly fuel and energy consumptions, boiler monthly fuel and energy consumptions, baseline monthly utility electricity costs, micro-CHP system monthly fuel energy costs, and micro-CHP monthly energy savings. System electrical, thermal, and total energy efficiencies are also calculated from the model.

\section{SIMULATION RESULTS}

This section of the paper presents a case study to evaluate the developed model. The case study includes the use of different prime movers in the same system setup to establish a comparison between the system performance of each. The case study simulates an office building that is powered, heated, and cooled by two different $10-\mathrm{kW}$ electric rated micro-CHP system configurations. The first system in comparison is powered by a spark ignition (SI) internal combustion engine, and the second system is powered by a compression ignition internal combustion engine. The prime mover/generator set will provide electrical power for normal office equipment and lighting during office hours. Waste heat from the prime mover will be used to heat water to operate either the absorption chiller for cooling or the heating coil. A waterfired absorption chiller is used with a rated cooling capacity of 10 tons and an average COP of 0.8 for all case studies. For both simulation cases the boiler efficiency, heat exchanger effectiveness, and pipe loss coefficient are assumed as $0.9,0.8$, and 0.95 , respectively. Figure 1 illustrates the schematic of the micro-CHP system used for all case studies. All monthly energy costs required for micro-CHP system operation are compared to the costs of buying electricity from the utilities for electric power and to operate an electric heat pump for heating and cooling purposes. 


\section{Building Specifications and Energy Requirements}

The following case study specifications are for an office space powered, heated, and cooled by a micro-CHP system located in Meridian, MS. The office space consists of a floor area of $4300 \mathrm{ft}^{2}$ and an average ceiling of $9 \mathrm{ft}$. Windows and glazings comprise of about $30 \%$ of the total wall area. The office building is in operation from 7:00 am to 7:00 pm for Monday through Friday.

Trace Load 700 [13] was used to predict energy load requirements for the previouslystated specifications. Figure 3a presents the total electrical energy usage and the average electrical load of approximately $7 \mathrm{~kW}$ required from the system for each month, and Figure $3 \mathrm{~b}$ shows the monthly heating and cooling loads required of the system. As expected the peak heating loads occur in the winter months of December through February, and the peak cooling loads occur during July and August. The maximum average heating load occurring in January is $10.9 \mathrm{~kW}$, and the maximum average cooling load occurring in August is $15.1 \mathrm{~kW} .10-\mathrm{kW}$ Rated Systems

The first prime mover simulated is a $10-\mathrm{kW}$ natural gas-fired internal combustion engine running at full capacity during office operational hours. When the building is closed, the microCHP system itself is turned off. The 4-cylinder 4-stroke engine has a cylinder volume of $0.00182 \mathrm{~m}^{3}$, a compression ratio of $8.5: 1$, and is run at $1800 \mathrm{RPM}$ at rated power. The rated airfuel ratio of the engine is 25 . For comparison purposes, a $10-\mathrm{kW}$ diesel engine is also simulated for the same building and energy loads. The 4-cylinder 4-stroke diesel engine has a cylinder volume of $0.001327 \mathrm{~m}^{3}$, a compression ratio of $19.5: 1$, a rated air-fuel ratio of 35 , and is also run at $1800 \mathrm{RPM}$ at rated power.

Figure 4 illustrates the fluctuations in the monthly fuel consumptions of the SI and diesel engines, respectively. Both monthly fuel mass consumptions and monthly fuel energy

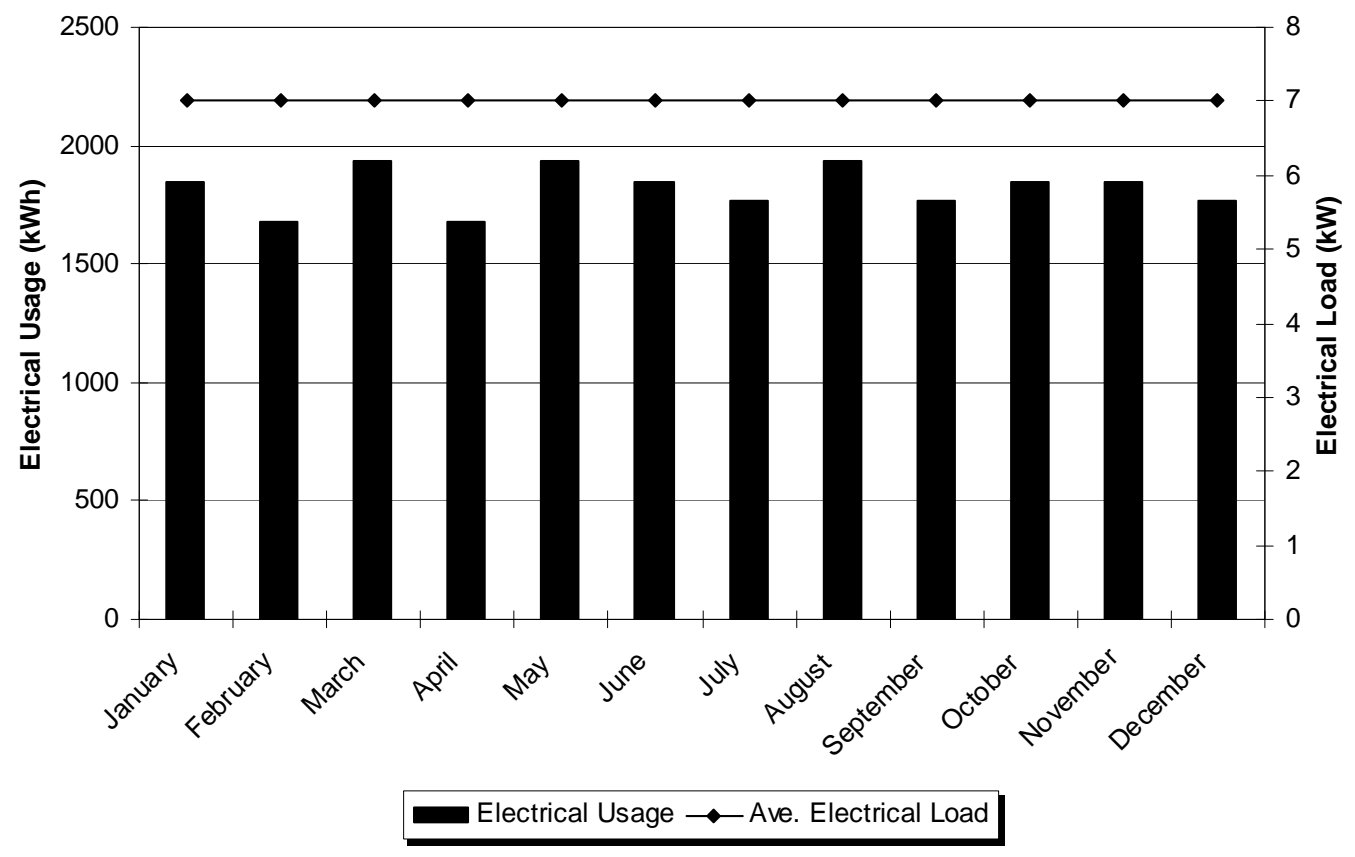

(a) 


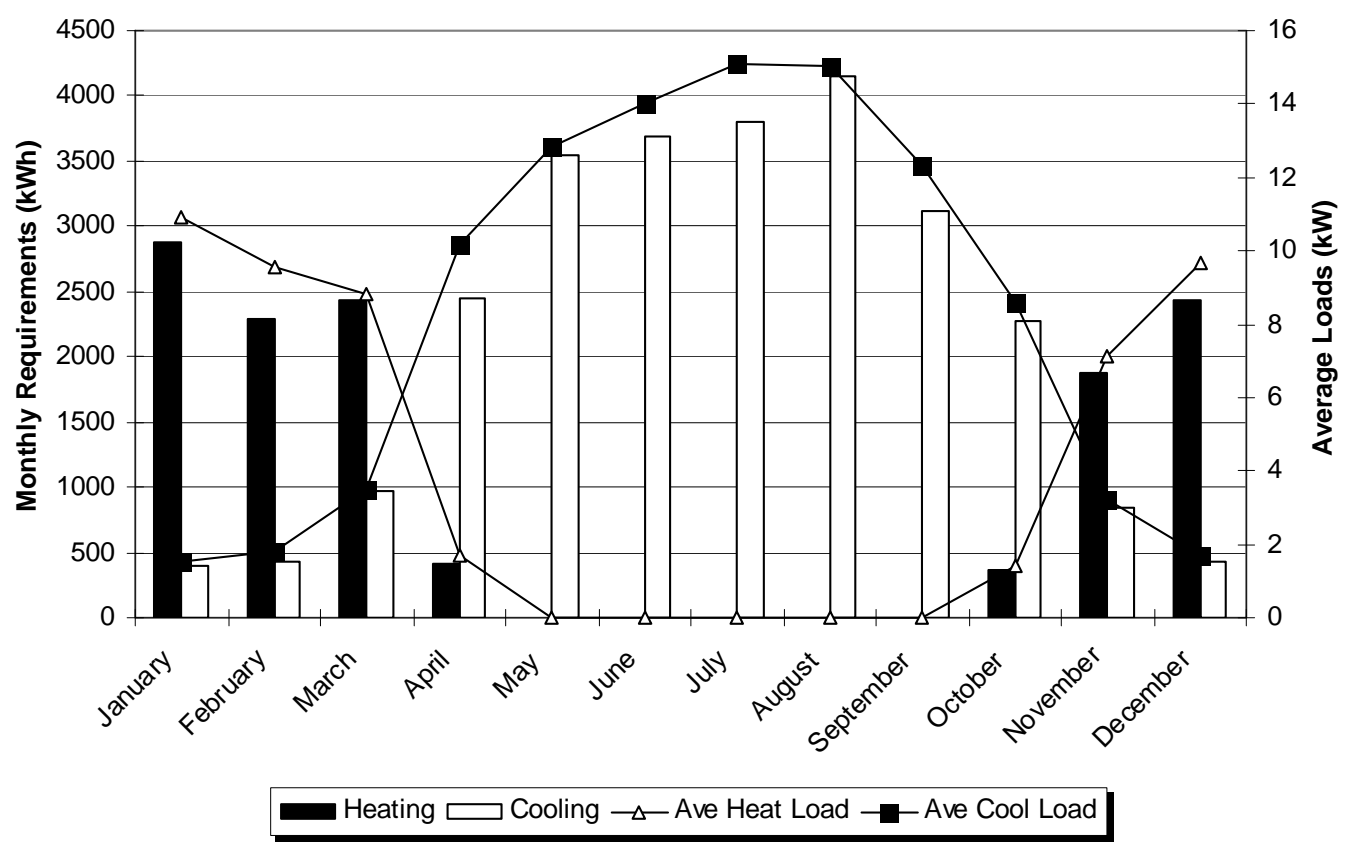

(b)

Figure 3. Case Study: (a) Monthly Electrical Requirements, (b) Monthly Heating and Cooling Requirements

consumptions are shown in the figure. Since both engines are modeled as running at rated power whenever in operation, the driving force behind any fluctuations in the monthly fuel consumption is the number of days that the system is in use for each month. From Figure 4, the monthly fuel consumptions as well as the monthly fuel energy consumptions required of the SI engine are higher than those of the diesel engine system. Figure 5 illustrates the monthly natural gas consumption required of the boiler in the system to account for high heating or cooling loads which cannot be satisfied by the recovered thermal energy of the prime mover. 


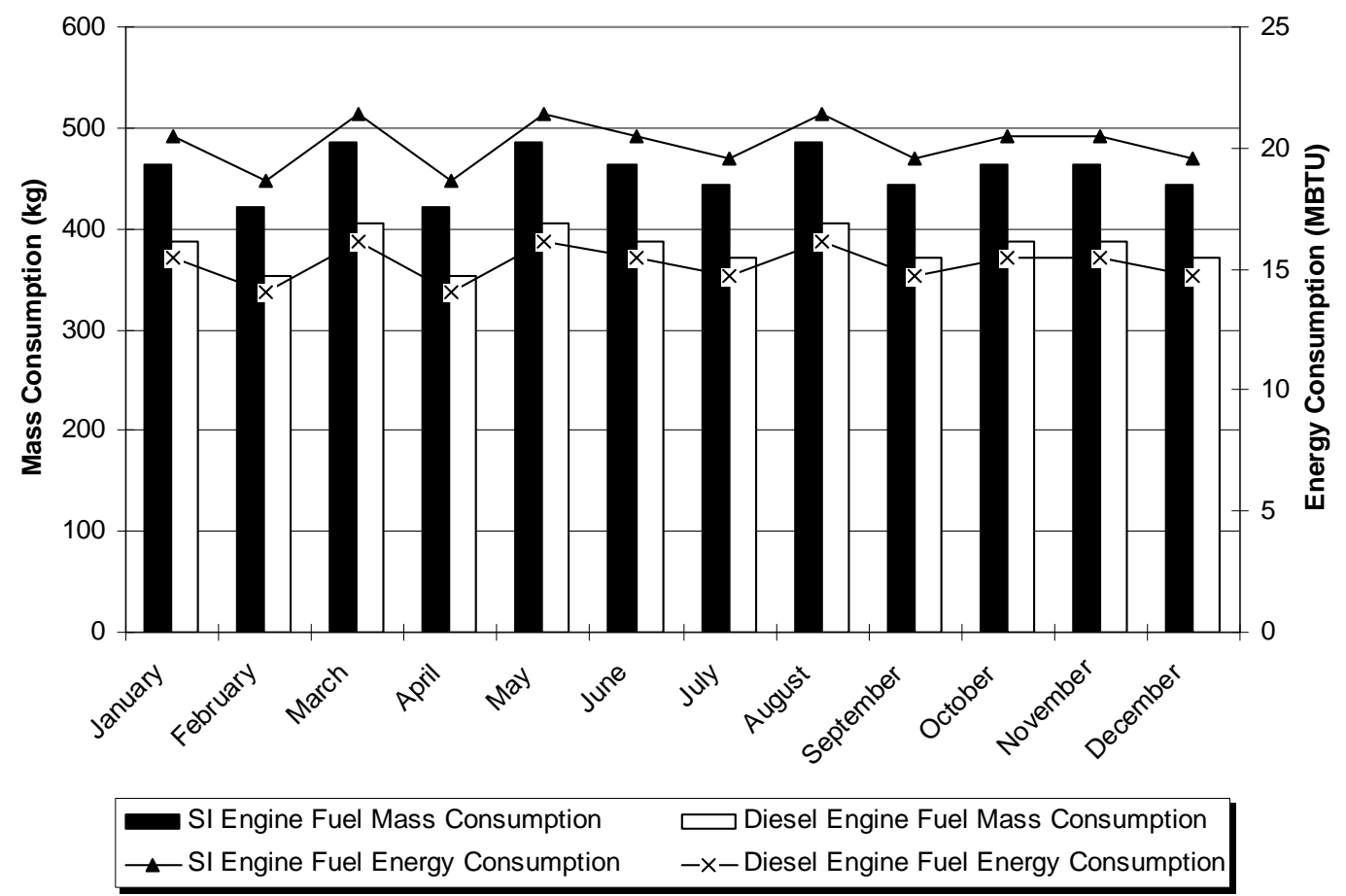

Figure 4. Prime Mover Monthly Fuel Consumption

As expected, the system powered by the diesel engine requires less fuel energy than a spark ignition combustion engine for an equivalent power output. A diesel engine generally has a better fuel combustion efficiency because of their higher compression ratios and leaner operating conditions. Therefore, a diesel engine will have a higher thermal efficiency than a SI engine and can meet the electrical power requirements with less fuel input. Since a SI engine presents lower fuel combustion efficiency, it has more waste heat, and can meet higher heating and cooling requirements than a diesel engine. For this reason, the diesel engine requires larger monthly boiler fuel consumption. Also, the largest boiler loads are necessary during the summer months when the absorption chiller is in constant use.

The monthly system electrical, thermal, and total efficiencies for both systems are given in Figure 6. The thermal efficiencies of both the SI engine system and diesel engine system are between $38 \%$ and $45 \%$, and the electrical efficiency of both systems fluctuates from $26 \%$ to $35 \%$. The drop in the electrical efficiency during the summer months is caused by the operation of a boiler to meet the high cooling needs that cannot be met by the recovered thermal energy of the engine, which, therefore, increases the total energy input into the system. An examination of 


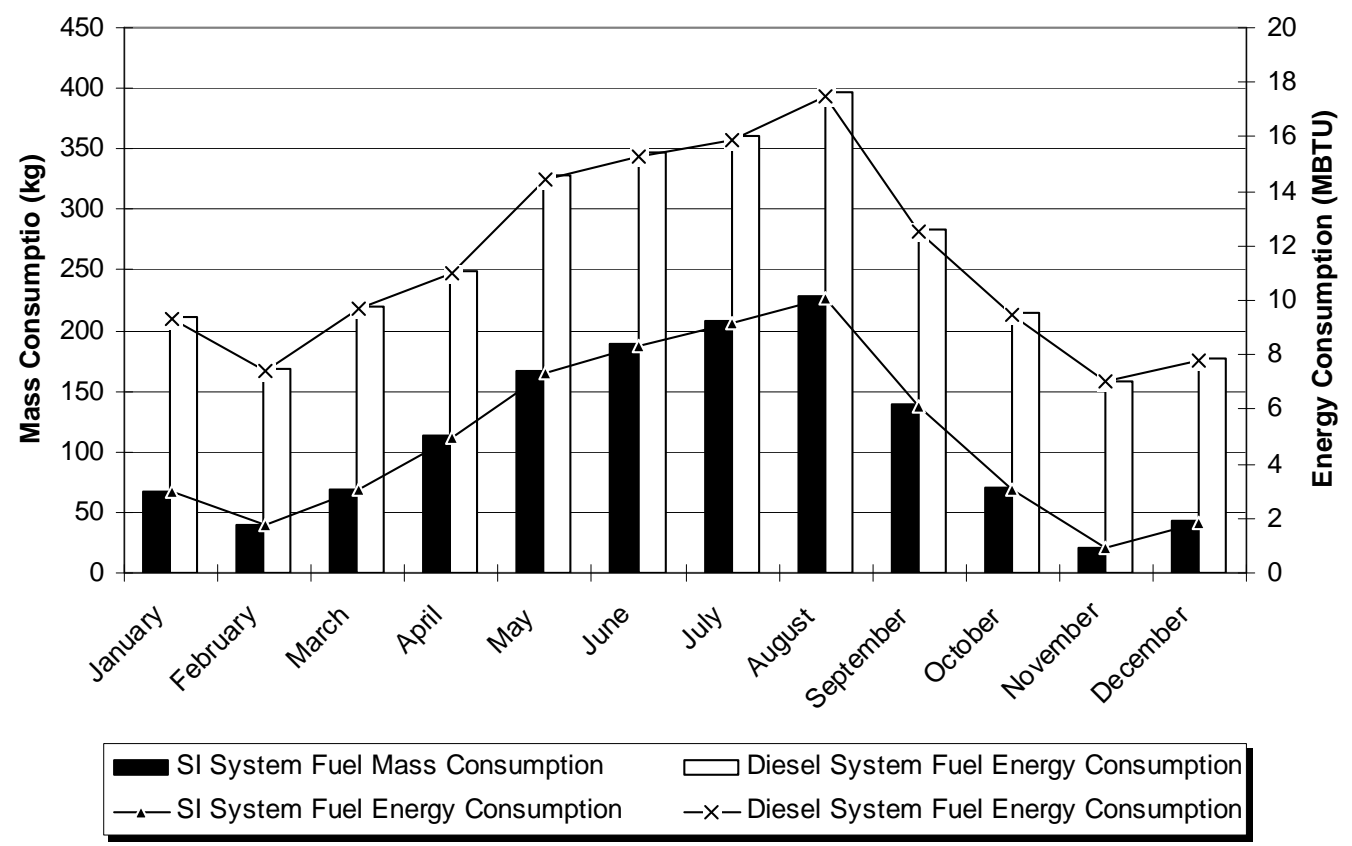

Figure 5. Boiler Monthly Fuel Consumption

the system schematic in Figure 1 reveals that the absorption chiller is used for cooling, and, therefore, increases the energy losses of the system; whereas, the heated water bypasses the absorption chiller and is sent straight to the heating coil when heating is required. The maximum system total efficiency of approximately $80 \%$ occurs in the colder months when the thermal loads nearly match the recoverable heat available from the prime mover. The highest total efficiencies from Figures $6 \mathrm{a}$ and $6 \mathrm{~b}$ coincide with the lowest boiler fuel consumption requirements from Figure 5 in the months of November through March.

The monthly energy costs of both of the micro-CHP systems and conventional electric power, heating, and cooling system are compared in Figure 7. For this comparison, natural gas rates are set at $\$ 8 / \mathrm{MMBTU}$ and the electric utility charges $\$ 0.075 / \mathrm{kWh}$ for usage and $\$ 6 / \mathrm{kW}$ month demand. The maximum monthly savings of the spark ignition micro-CHP system are found in the months of November through February and are in excess of $\$ 100 /$ month. The total energy cost savings for the entire year for the SI and diesel systems are $\$ 1140$ and $\$ 995$, respectively. The minimum savings occur during the hottest months of July and August. This minimum is caused by the boiler operation during these months to satisfy the high cooling loads.

For this case study, the fuel prices of both natural gas and no. 2 diesel were set at \$8/MMBTU. Fuel prices are continuously fluctuating, and, therefore, a fuel price will not remain constant for an entire year. Figures 8 and 9 illustrate the monthly savings (or costs including the fuel used in the engine and in the boiler) that are possible for different fuel prices for the two systems simulated. This In Figure 9, the legend labels the lines in pairs of fuel prices since both diesel fuel and natural gas are required by the system. The first value is the diesel price, and the second value is the natural gas price. Monthly energy savings for the SI-engine system disappear when the natural gas cost is between \$10/MMBTU and \$12/MMBTU. Savings do not occur when one of the following three situations happen for the diesel engine system: 
Diesel - \$4/MBTUNatural Gas - \$16/MBTU

Diesel-\$10/MBTU Natural Gas-\$10/MBTU

Diesel-\$16/MBTU Natural Gas-\$4/MBTU

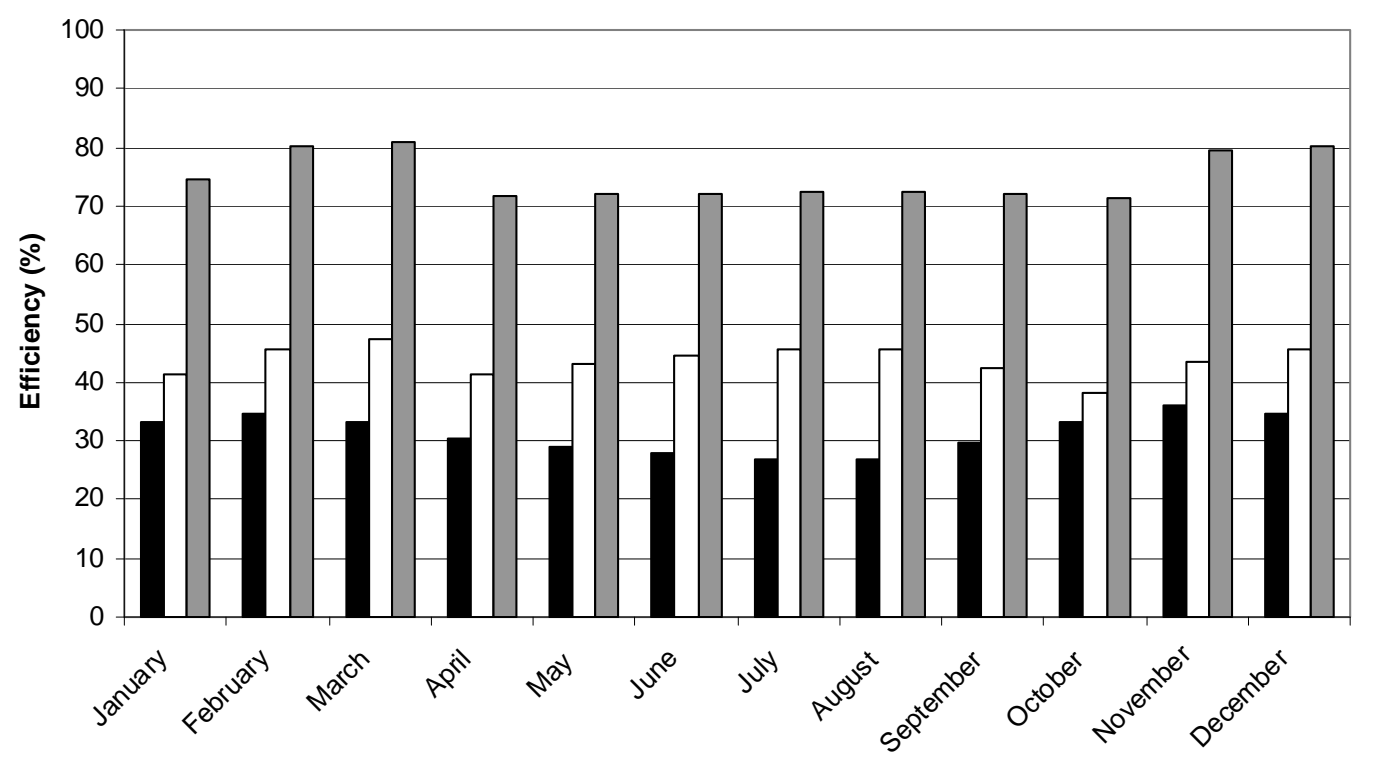

- Electrical $\square$ Thermal $\square$ Total

(a)

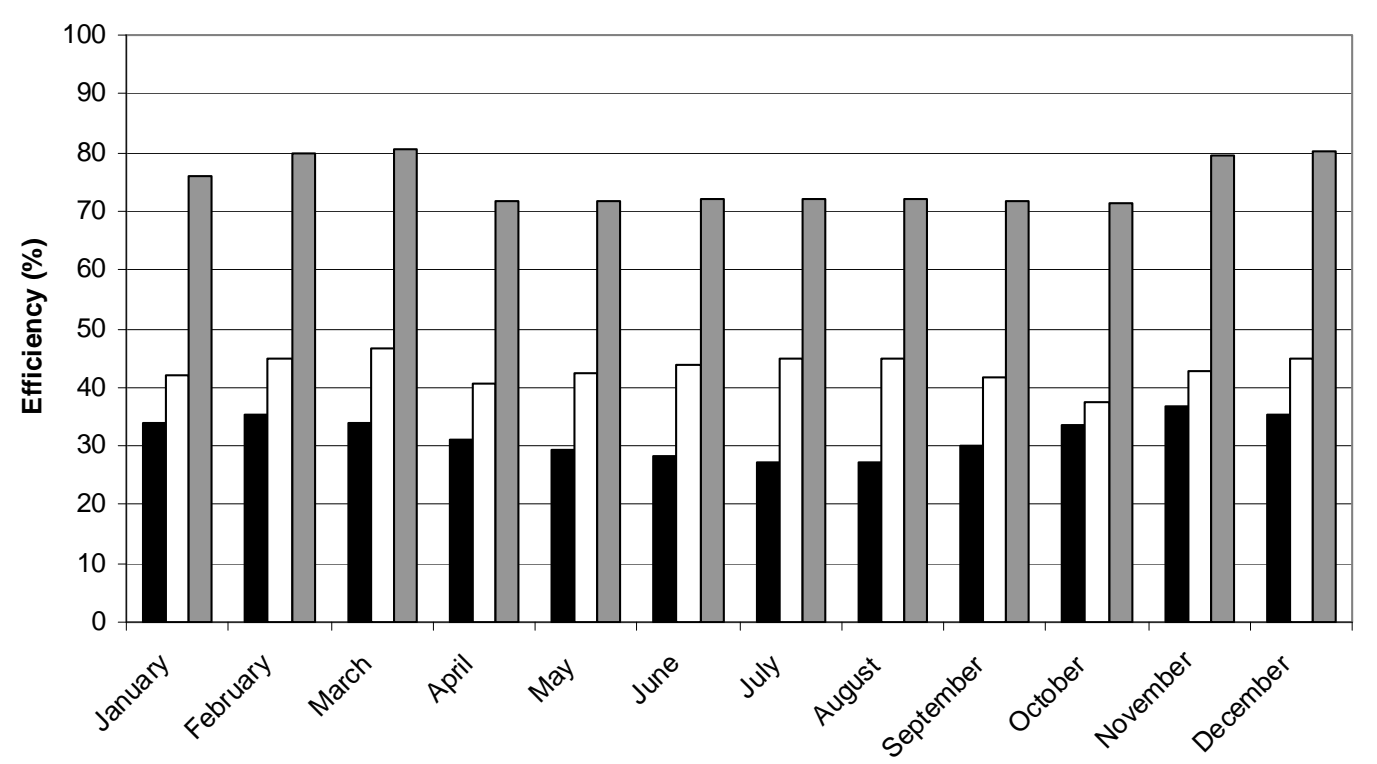

- Electrical $\square$ Thermal $\square$ Total

(b)

Figure 6. Case Study: (a) SI Engine Micro-CHP System Efficiencies, (b) Diesel Engine MicroCHP System Efficiencies 


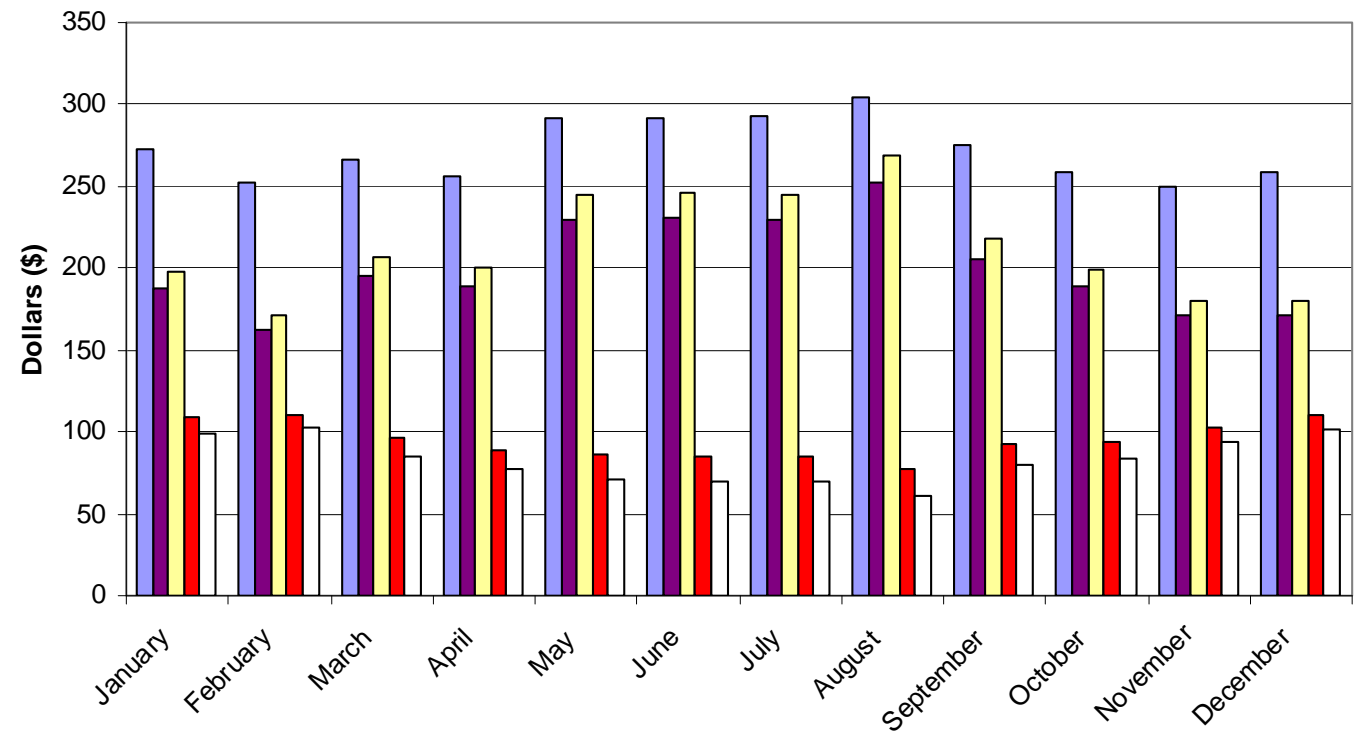

$\square$ Conventional Costs $\square$ SI Engine Costs $\square$ Diesel Engine Costs $\square$ SI Engine Savings $\square$ Diesel Engine Savings

Figure 7. Micro-CHP versus Conventional Energy Costs

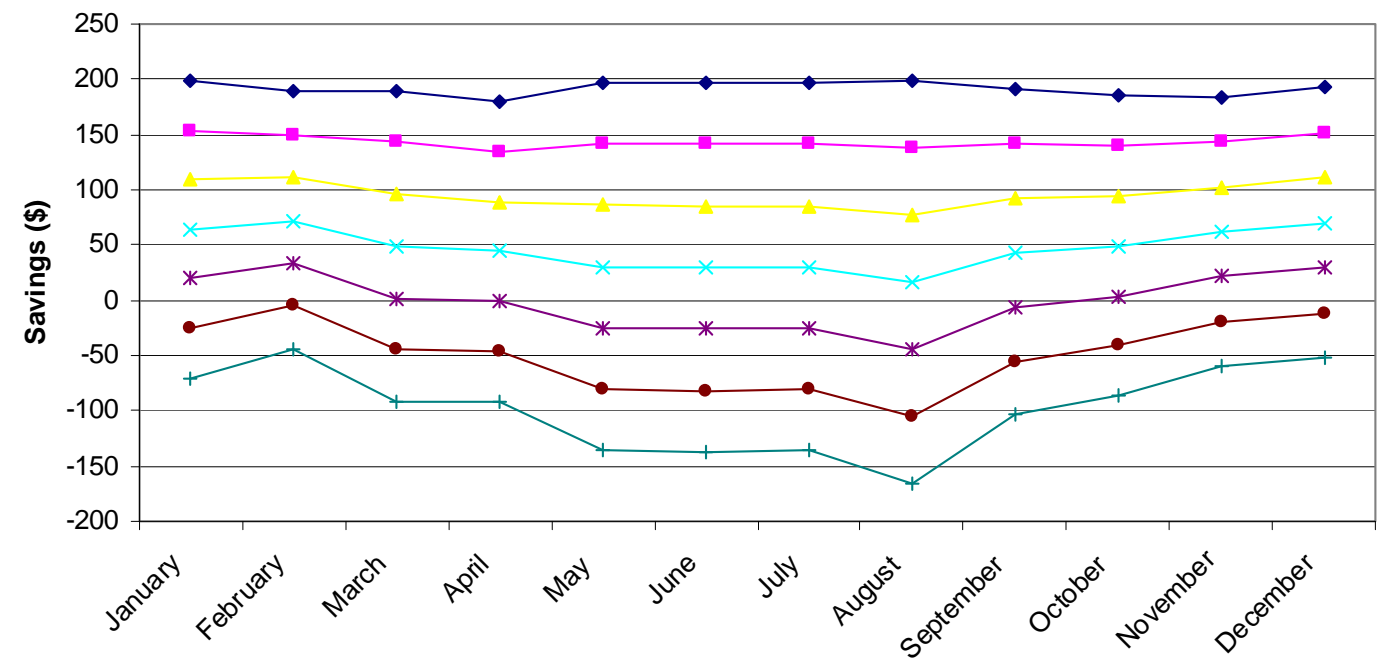

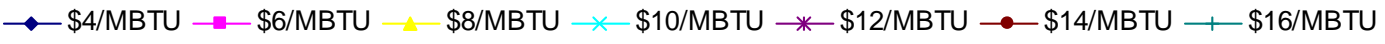

Figure 8. SI Engine Micro-CHP Energy Savings 


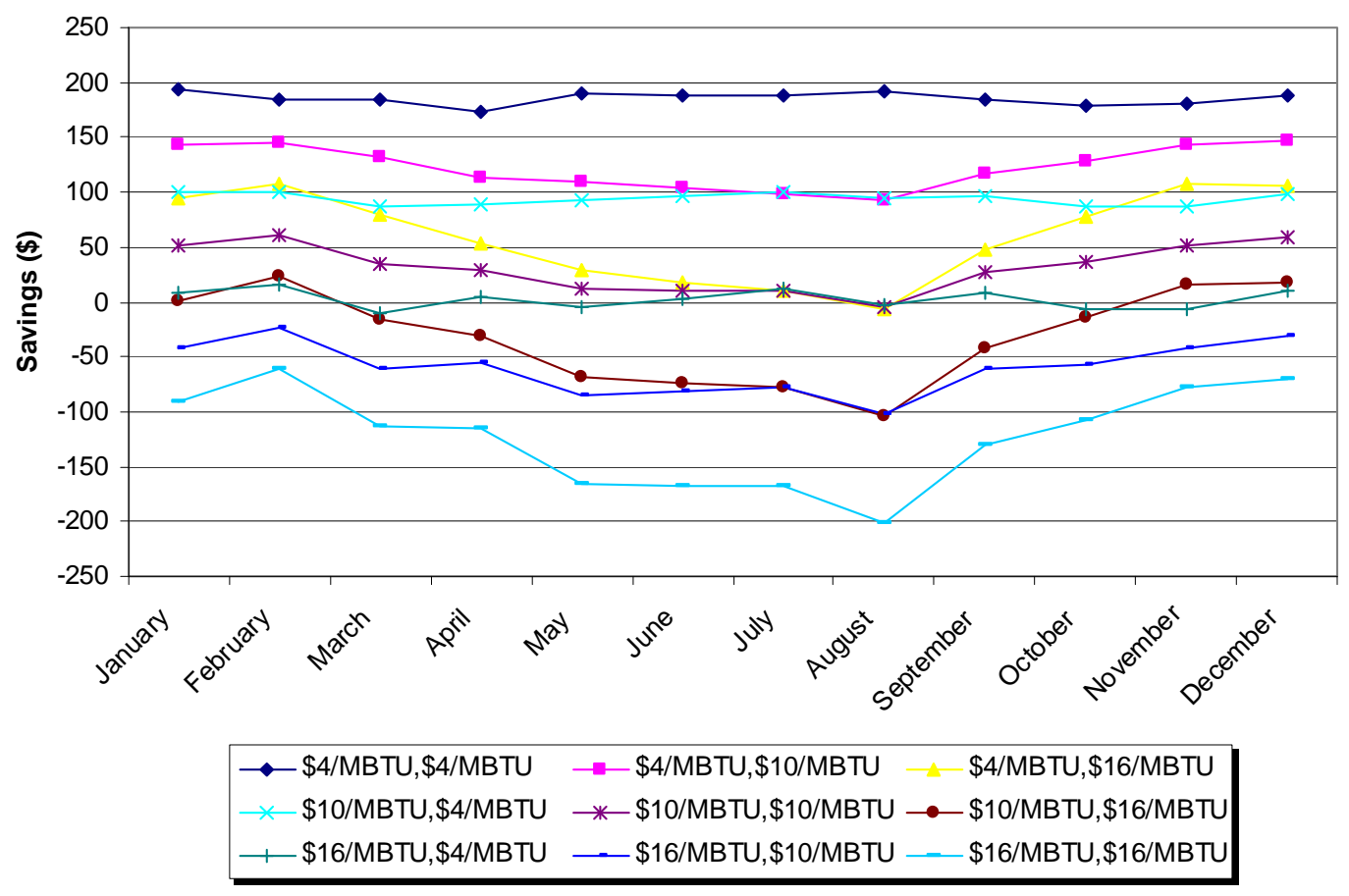

Figure 9. Diesel Engine Micro-CHP Energy Savings

\section{CONCLUSION}

This article presents a micro-CHP model composed of individual component models. Two micro-CHP systems were simulated. A case study was used to demonstrate differences in the system performances of micro-CHP systems driven by different prime movers. Prime movers simulated include a $10-\mathrm{kW}$ natural gas internal combustion engine and a $10-\mathrm{kW}$ diesel engine. The 10-kW systems had similar performance outputs, and total system efficiencies in cooler months of up to $80 \%$ were obtained. The simulation established that the more efficient diesel engine produced smaller savings at $\$ 8 / \mathrm{MMBTU}$. The diesel engine has less rejected heat than the natural gas internal combustion engine, and it cannot satisfy as much of the heating and cooling loads without the use of the boiler than can the natural gas internal combustion engine.

An important issue of prime mover selection and sizing is raised from this investigation. The ratio of required heating and cooling loads compared to the required electrical loads must be taken into consideration when choosing a prime mover. If a prime mover is selected that cannot accommodate high heating and cooling loads, then a boiler which will raise monthly fuel consumption is required. A prime mover should be chosen to handle both electrical and thermal loads (or as close as may be possible) at whatever power is necessary. Also, a thermal loadfollowing system should be picked and sized so that large amounts of excess electricity are not produced unless selling the excess electricity back to the grid is an economical option. The high prime mover thermal efficiency of diesel engines makes them best suited for micro-CHP applications that have a lower ratio of required thermal to electrical loads.

Micro-CHP systems are observed in the models to have better input energy utilization than conventional power plants that only utilize a maximum of $50 \%$ of their fuel input. Conventional power plants reject the thermal energy into the atmosphere and, therefore, have 
higher harmful emissions to the atmosphere than does a micro-CHP system per $\mathrm{kWh}$ energy requirement, which can utilize up to $80 \%$ of its input fuel energy. Also, micro-CHP systems have higher fuel flexibility and are capable of using more "environmentally friendly" fuels than conventional coal power plants. The models also show that at certain fuel price and electricity rate conditions, micro-CHP systems can produce noticeable savings in monthly energy costs. Conditions that are required for a micro-CHP system to produce monthly energy savings include low micro-CHP system fuel costs, high electricity rates, and needs for both electrical and thermal energy for the building or space to correlate with the ratio of electrical and thermal energy production of the prime mover. For the specified utility rate conditions, the case study showed that fuel priced at $\$ 11 / \mathrm{MBTU}$ is the limit to micro-CHP savings production.

Average electrical, heating, and cooling loads required from the system for each month are used as inputs for the micro-CHP model, and the prime movers are run at maximum power. While these average loads and constant power settings are useful in making comparisons of different prime movers, a model with load-following capabilities would increase the accuracy of system performance predictions. Hourly predictive energy load data could be input to the system and give a better indication of actual system performance.

\section{REFERENCES}

[1] Harrison, J., 2003, "Micro CHP in Rural Areas," EarthScan James \& James. 1 January, 2003.

[2] Harrison, J. 2003, "Micro CHP in Europe" EA Technology. Presentation at the 2003 National Micro CHP Technology Pathways Workshop.

[3] Harrison, J., 2003, “Towards a Strategy for micro CHP in the USA Domestic Markets," EA Technology (C) June 2003.

[4] Flin, D., 2005, "Domestic CHP in Europe," Cogeneration and On-Site Power Production, Jan. - Feb. 2005, pp. $43-49$.

[5] Jalalzadeh-Azar, A., Slayzak, S., and Ryan, J., 2002, "Evaluation of Cooling, Heating, and Power (CHP) for Office Buildings," ASHRAE Transactions, 108 (1), pp. 1045-1051

[6] Jalalzadeh-Azar, A., 2004, "A Comparison of Electrical- and Thermal-Load-Following CHP Systems." AHSRAE Transactions, 110 (1), pp. 85-94.

[7] U.S. Department of Energy. Energy Efficiency and Renewable Energy. Available at www.eere.energy.gov.

[8] Onovwiona, H. and Ugursal, V. "Residential cogeneration systems: a review of the current technology," Renewable and Sustainable Energy Reviews 10 (2006): 389-431.

[9] Oliver, J. "A micro-Cooling, Heating, and Power (m-CHP) Instructional Module," Thesis. Mississippi State University, 2005.

[10] Pulkrabek, W. W. Engineering Fundamentals of the Internal Combustion Engine. $2^{\text {nd }}$ ed. Upper Saddle River, NJ: Prentice-Hall, 2004.

[11] Incropera, F. P., and Dewitt, D. P. Fundamentals of Heat and Mass Transfer. $5^{\text {th }}$ ed. New York: Wiley \& Sons, 2002. 
[12] Kuehn, T. H., Ramsey, J. W., and Threlkeld, J. L. Thermal Environmental Engineering. $3^{\text {rd }}$ ed. Upper Saddle River, NJ: Prentice Hall, 1998.

[13] TRACE 700 Load Design. Trane. Available at www.trane.com/commercial/software/load700/

[14] California Energy Commission. California Distributed Energy Resource Guide. Oct 2004. Available at www.energy.ca.gov/distgen

\section{SENSITIVITY ANALYSIS AND UNCERTAINTY QUANTIFICATION FOR A MICRO-CHP MODEL}

\section{INTRODUCTION}

The term CHP (Cooling, Heating, and Power) describes all electrical power generation systems that utilize recoverable waste heat for space heating, cooling, and domestic hot water purposes. CHP has proven beneficial in many large-scale applications (hospitals, etc.) by providing higher quality, more reliable power while generating high total energy efficiencies. Micro-CHP systems can be applied in single family homes, small apartment complexes, or small office buildings. In a typical micro-CHP system, electricity is generated on-site from the combustion of a fuel source in an electrical generation set (prime mover and generator). This combustion produces recoverable heat in the form of heated engine coolant and high temperature exhaust. The use of the recoverable thermal energy for space heating and cooling purposes is the driving factor behind the increased overall energy usage from conventional power generation systems. Approximately $85 \%$ of the energy put into a system is used for either electrical power or heating and cooling purposes. A traditional power plant will generally only convert $30 \%$ of the system energy input to electrical energy. The other $70 \%$ may be released into the atmosphere as waste heat. Another advantage that micro-CHP systems have over traditional central power plants is the difference in energy costs. The only energy cost involved in a micro-CHP system is the cost to supply the fuel necessary to run the prime mover, whereas, in a traditional system, the energy consumer has to pay monthly power demand and electrical energy usage charges for all electrical power. Jalalzadeh-Azar et al. [1] performed an evaluation based on a nondimensional analysis of energy cost and primary energy consumption of CHP systems for office buildings using two CHP scenarios for an office building in three different geographical locations. He used gas-fired micro-turbine generators in all cases to provide on-line electricity and thermal energy for the building. He reported the effect of power generator efficiency on the total primary energy consumption and cost.

A methodology for calculating performance characteristics of different micro-CHP system components is introduced in this paper. In this paper, a spark-ignition internal combustion engine is modeled using the Otto cycle. Calculations using heat exchanger, absorption chiller, and boiler modeling are also presented. The individual component models are then linked together to calculate total system performance values.

Performance characteristics that are observed for the system include total monthly fuel consumption and system energy (electrical, thermal, and total) efficiencies. Also, whether or not both the required electrical and thermal loads can sufficiently be accounted for within the system specifications is observed. In addition to these observations, uncertainties associated with model 
inputs are of great importance. Therefore, a complete sensitivity and uncertainty analysis must be performed to determine simulation uncertainty. The purpose of this quantitative uncertainty analysis is to use currently available information in order to determine the degree of confidence in the presented data and model simulations. For problems where data are limited and where simplifying assumptions have been used, quantitative uncertainty analysis can provide an illuminating role, to help identify how strong the conclusions about model results are, and to help target data gathering efforts [2]. Moreover, A detailed uncertainty analysis provides insight into the level of confidence in model simulations, and can aid in assessing how various possible model input uncertainties should be weighed. An uncertainty analysis can lead to the identification of the key sources of uncertainty, which merit further research, as well as the sources of uncertainty that are not important with respect to a given response. In order to perform the uncertainty analysis of the presented model, a case study for a micro-CHP system has been discussed and compared. The objective of this study is to perform a detailed uncertainty analysis on simulation results of the overall micro-CHP efficiency and the amount of fuel required to operate the system. Of course, many times, experimental data are used to validate model simulations. In this type of analysis, the model inputs with associated uncertainties are measured during the experiments utilized in the validation exercise. In order to provide a quantitative answer as to the fidelity of the model simulations when compared to experimental data, these inputs and uncertainties must be used in the model uncertainty analysis so that the comparison is made at similar conditions. In this paper, methodology needed to estimate the uncertainty associated with simulation results is performed and discussed in detail.

\section{NOMENCLATURE}

$\begin{array}{ll}A F & \text { Air-fuel ratio } \\ c_{p} & \text { Specific heat at constant pressure }(\mathrm{kJ} / \mathrm{kg}-\mathrm{K}) \\ c_{v} & \text { Specific heat at constant volume }(\mathrm{kJ} / \mathrm{kg}-\mathrm{K}) \\ C & \text { Cost } \\ C O P & \text { Coefficient of performance } \\ E & \text { Electricity }(\mathrm{kJ}) \\ \dot{E} & \text { Electrical power }(\mathrm{kW}) \\ h r_{o p} & \text { Operational hours } \\ L H V & \text { Lower heating value }(\mathrm{kJ} / \mathrm{kg}) \\ m & \text { Mass }(\mathrm{kg}) \\ \dot{m} & \text { Mass flow rate }(\mathrm{kg} / \mathrm{s}) \\ N & \text { Number of cylinders } \\ P & \text { Pressure }(\mathrm{kPa}) \\ \dot{Q} & \text { Heat transfer rate }(\mathrm{kW}) \\ \dot{Q}_{A C, \text { threshold }} & \text { Maximum amount of cooling possible from the absorption chiller } \\ r_{v} & \text { Compression ratio }\left(\mathrm{m}^{3} / \mathrm{m}^{3}\right) \\ R & \text { Ideal gas constant }(\mathrm{kJ} / \mathrm{kg}-\mathrm{K}) \\ R P M & \text { Revolutions per minute } \\ R_{s} & \text { Stroke ratio } \\ T & \text { Temperature }(\mathrm{K}) \\ V & \text { Total cylinder volume }\left(\mathrm{m}^{3}\right)\end{array}$




\begin{tabular}{|c|c|}
\hline$V_{d}$ & Cylinder displacement volume $\left(\mathrm{m}^{3}\right)$ \\
\hline$V_{c}$ & Cylinder clearance volume $\left(\mathrm{m}^{3}\right)$ \\
\hline$V_{E}$ & Total displacement volume for engine $\left(\mathrm{m}^{3}\right)$ \\
\hline$w$ & Specific work $(\mathrm{kJ} / \mathrm{kg})$ \\
\hline$W$ & Work $(\mathrm{kJ})$ \\
\hline$\dot{W}$ & Mechanical power $(\mathrm{kW})$ \\
\hline$\eta$ & Efficiency \\
\hline$\xi$ & Pipe loss coefficient \\
\hline$\varepsilon$ & Heat exchanger effectiveness \\
\hline \multicolumn{2}{|l|}{ Subscripts } \\
\hline$A C$ & Absorption chiller \\
\hline air & Properties of air \\
\hline available & Available thermal energy \\
\hline$b, o p$ & Required boiler operation \\
\hline boiler & Boiler \\
\hline$c p$ & Properties of combustion products \\
\hline elec & Conventional electrical usage \\
\hline electrical & System electrical efficiency \\
\hline evap & Cooling power of $\mathrm{AC}$ evaporator \\
\hline excess & Excess electricity produced by system \\
\hline exhaust, gen & Exhaust exiting absorption chiller generator \\
\hline exhaust,PM & Exhaust exiting the prime mover \\
\hline fuel & Properties or flow rates of fuel \\
\hline gen & Generator \\
\hline generated & Electricity generated by micro-CHP system \\
\hline mech & Mechanical work or power \\
\hline $\operatorname{mix}$ & Flow rates or mass values of mixture \\
\hline net & Net specific work or power \\
\hline thermal & System thermal efficiency \\
\hline total & System total efficiency \\
\hline usage & Electrical usage requirements \\
\hline water & Properties or flow rates of water \\
\hline$w$, in,$H X$ & Water entering heat exchanger \\
\hline$w$, in, gen & Water entering the absorption chiller generator \\
\hline$w$, out, gen & Water exiting absorption chiller generator \\
\hline$w$, outHX & Water exiting heat exchanger \\
\hline
\end{tabular}

\section{ANALYSIS}

To study and evaluate the performance of micro-CHP systems, thermodynamic models of the different components have to be developed. Although the analysis of simplified thermodynamic models generally leads only to qualitative conclusions about the system performance, these models allow the evaluation of how the changes in operating parameters affect the actual system 
performance. A schematic of the micro-CHP system analyzed in this paper is shown in Figure 1. The equations used to model each individual component are presented in Section 1.

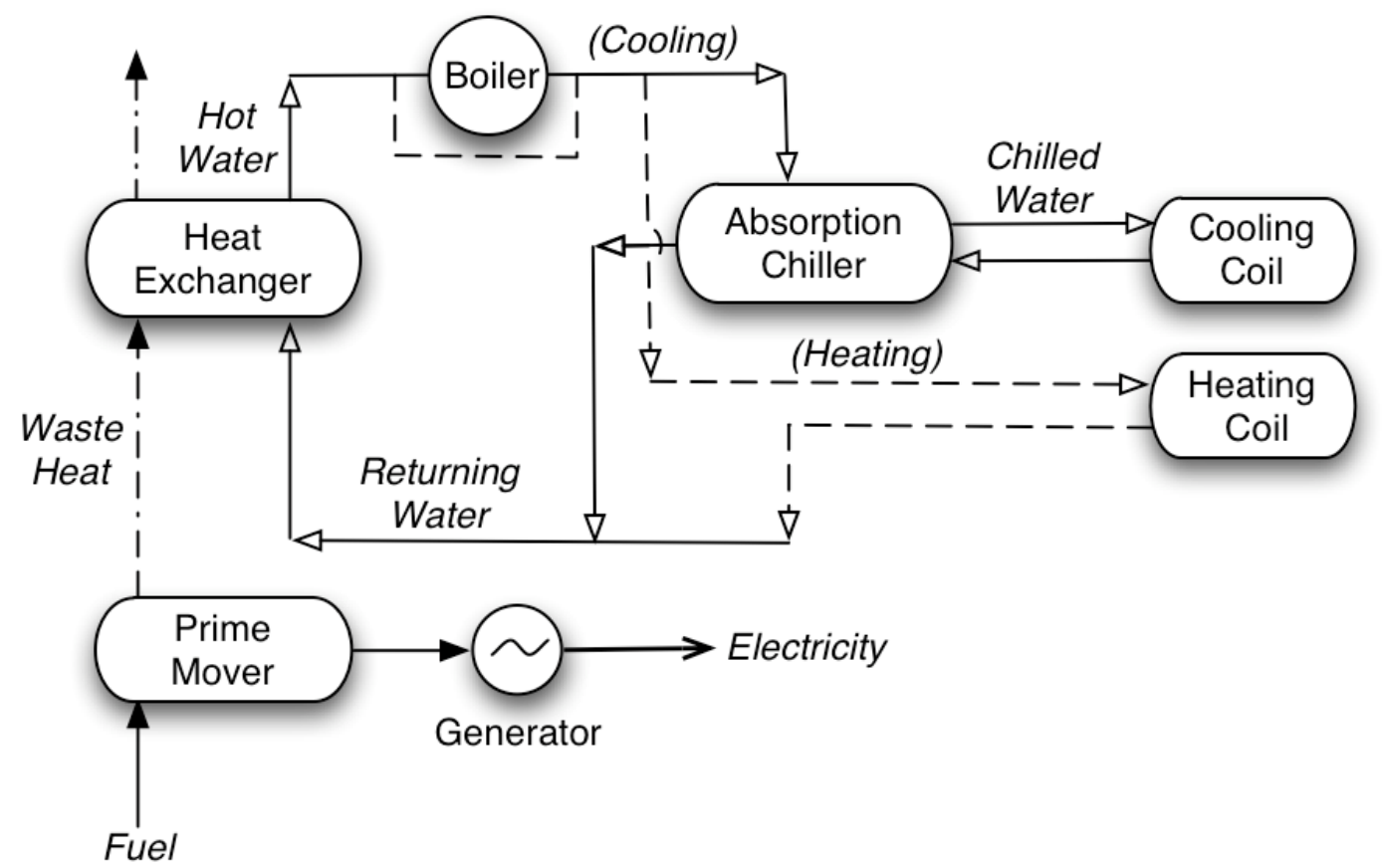

Figure 1. Micro-CHP Case Study Schematic

\section{MODEL UNCERTAINTY}

In order to predict the performance of the micro-CHP model developed in this investigation, a complete sensitivity and uncertainty analysis was performed for the simulation results. Ideally, simulation results have to be compared with experimental results in order to complete a Verification and Validation (V\&V) effort. This paper presents the first part of a V\&V process which includes the determination of the uncertainty in the simulation results. This paper focuses on the uncertainty analysis for the simulation results of overall system efficiency and fuel mass consumption. In order to conduct an appropriate uncertainty analysis, all of the important parameters and their associated uncertainties must be identified. For each variable, the uncertainties were calculated using a combination of manufacturer's specifications, engineering judgment and experience, analytical models, and previous data.

The simulation uncertainty was determined using the uncertainty propagation equation [8]

$\frac{U_{S}}{S}=\left[\left(\frac{Y_{1}}{S} \frac{\partial S}{\partial Y_{1}}\right)^{2}\left(\frac{U_{Y_{1}}}{Y_{1}}\right)^{2}+\left(\frac{Y_{2}}{S} \frac{\partial S}{\partial Y_{2}}\right)^{2}\left(\frac{U_{Y_{2}}}{Y_{2}}\right)^{2}+\ldots+\left(\frac{Y_{J}}{S} \frac{\partial S}{\partial Y_{J}}\right)^{2}\left(\frac{U_{Y_{J}}}{Y_{J}}\right)^{2}\right]^{0.5}$

where the $Y_{i}$ terms represent the input variables to the model. For this analysis, the derivatives were determined numerically using a forward-differencing finite-difference approach which is presented in the equation below 


$$
\left.\frac{\partial S}{\partial Y_{1}}\right|_{Y_{2}, \ldots, Y_{\text {Jonsis }}}=\frac{\Delta S}{\Delta Y_{1}}=\frac{S_{Y_{1}+\Delta Y_{1}, Y_{2}, \ldots, Y_{\text {Sconst }}}-S_{Y_{1}, Y_{2}, \ldots, Y_{\text {Sonst }}}}{\Delta Y_{1}}
$$

with similar expressions for the derivatives with respect to $Y_{2}$ and $Y_{j}$.

In addition to the simulation uncertainty calculated using Equation (2), other useful information such as the Uncertainty Magnification Factor $(U M F)$ and Uncertainty Percentage Contribution $(U P C)$ for each variable can be obtained using Equations (3) and (4).

$$
\begin{aligned}
U M F_{i} & =\frac{Y_{i}}{m} \frac{\partial m}{\partial Y_{i}} \\
U P C_{i} & =\frac{\left(\partial m / \partial Y_{i}\right)^{2} U_{Y_{i}}^{2}}{U_{m}^{2}} 100
\end{aligned}
$$

The $U M F$ indicates the influence of the uncertainty in variable $Y_{i}$ on the uncertainty in the model. The UPC is the percentage contribution that each variable uncertainty has on the simulation uncertainty.

\section{SIMULATION RESULTS}

This section of the paper presents a case study to evaluate the developed model and its respective uncertainty. The case study simulates an office building that is powered, heated, and cooled by a $10-\mathrm{kW}$ electric rated micro-CHP system configuration. This system is powered by a spark ignition internal combustion engine. The prime mover/generator set provides electrical power for normal office equipment and lighting during office hours. Waste heat from the prime mover will be used to heat water to operate either the absorption chiller for cooling or the heating coil. A water-fired absorption chiller is used with a rated cooling capacity of 10 tons and an average COP of 0.75 for all case studies. For this simulation case, the boiler efficiency, heat exchanger effectiveness, and pipe loss coefficient are assumed as 0.9, 0.75, and 0.90, respectively. Figure 1 illustrates the schematic of the micro-CHP system used for this case study.

\section{Building and Prime Mover Specifications and Energy Requirements}

The following case study specifications are for an office space powered, heated, and cooled by a micro-CHP system located in Meridian, MS. The office space consists of a floor area of $4300 \mathrm{ft}^{2}$ and an average ceiling of $9 \mathrm{ft}$. Windows and glazings comprise of about $30 \%$ of the total wall area. The office building is in operation from 7:00 am to 7:00 pm for Monday through Friday. Trace Load 700 [9] was used to predict energy load requirements. Figure 2a presents the total electrical energy usage and the average electrical load of approximately $7 \mathrm{~kW}$ required from the system for each month, and Figure $2 \mathrm{~b}$ illustrates the monthly heating and cooling loads required of the system. The peak heating loads occur in the winter months of December through February, and the peak cooling loads occur during July and August. The maximum average heating load occurs in January $(10.9 \mathrm{~kW})$, and the maximum average cooling load occurs in August (15.1 kW).

The prime mover simulated is a $10-\mathrm{kW}$ natural gas-fired internal combustion engine running at full-load during operational office hours. When the building is closed, the micro-CHP system itself is turned off. The 4-cylinder 4-stroke engine has a cylinder volume of $0.00182 \mathrm{~m}^{3}$, a compression ratio of $8.5: 1$, and is run at $1800 \mathrm{RPM}$ at rated power. The rated air-fuel ratio of the engine is 16 . 
The model inputs and associated uncertainties used in the simulation uncertainty calculations are presented in Table 1. As mentioned before, the value of the uncertainty for each variable was calculated using a combination of manufacturer's specifications, engineering judgment and experience, analytical models, and previous data published in the literature. Some of the literature used to determine the uncertainties of the variables include: [10-15].

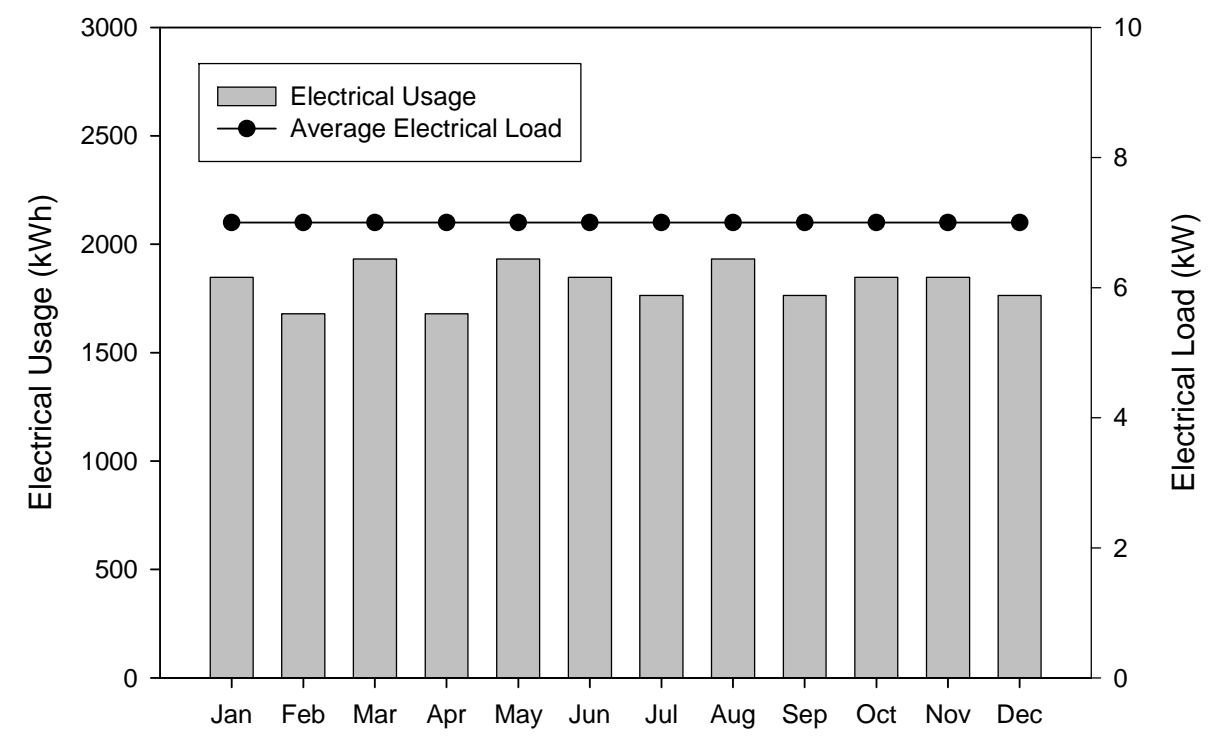

(a)

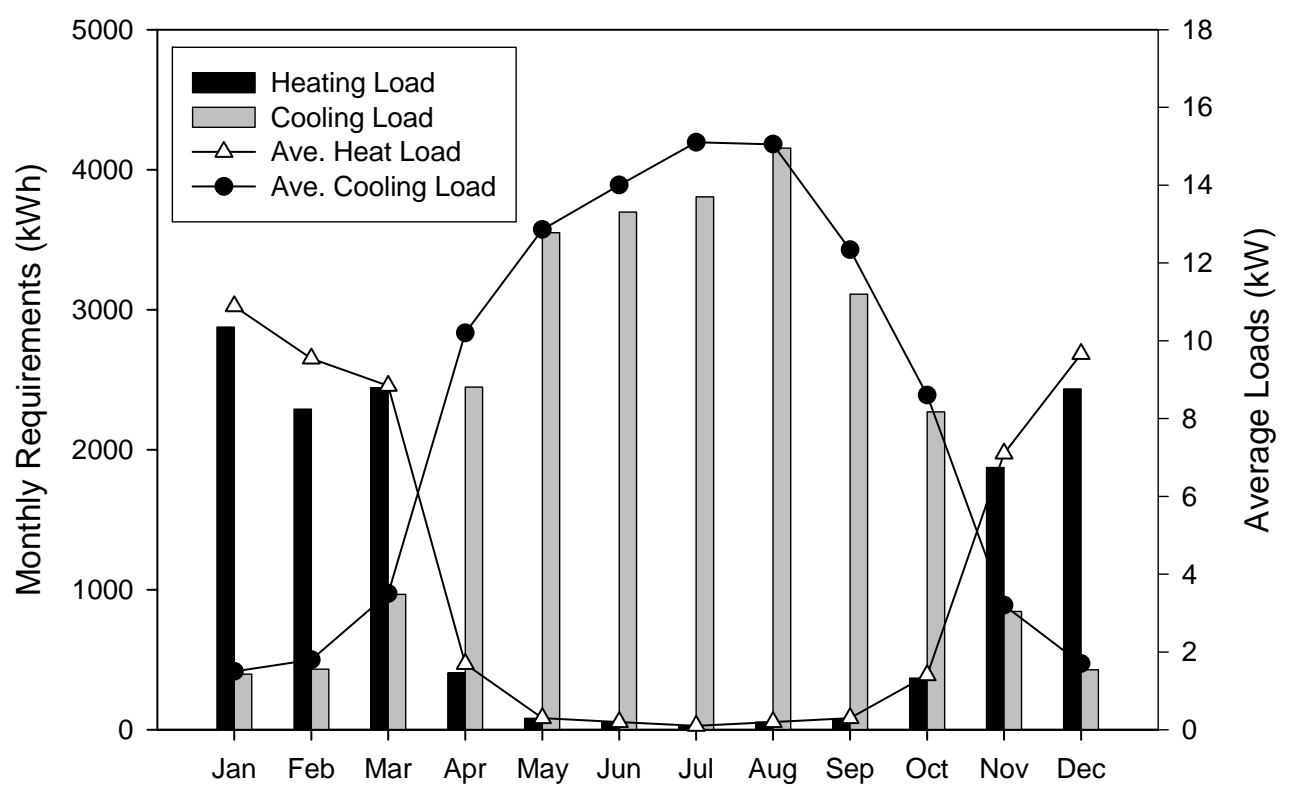

(b)

Figure 2. Case Study: (a) Monthly Electrical Requirements, (b) Monthly Heating and Cooling Requirements 


\section{Model Results}

Figure 3 illustrates the fluctuations in the monthly fuel consumptions of the CHP prime mover and the boiler. Since the engine is modeled at full-load while in operation, the driving force behind any fluctuations in the monthly fuel consumption is the number of days that the system is in use for each month. Figure 3 also illustrates the monthly natural gas consumption required of the boiler to account for high heating or cooling loads not satisfied by the recovered thermal energy of the prime mover.

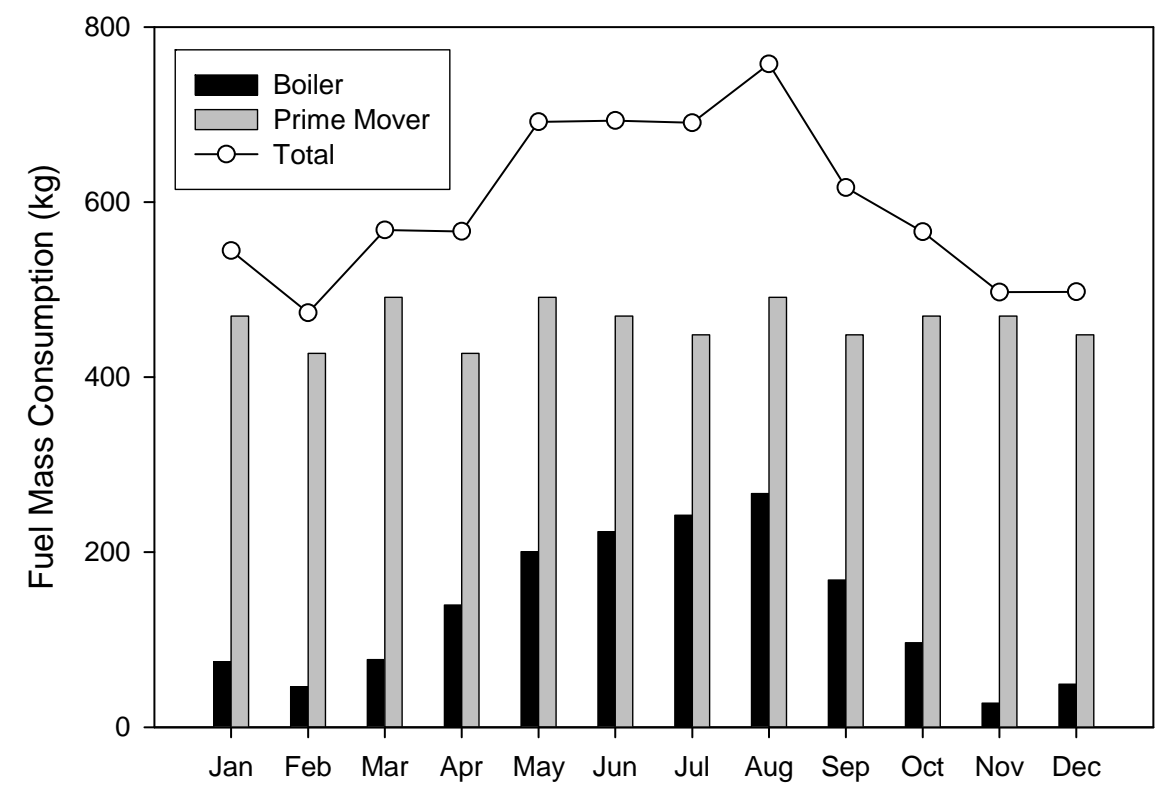

Figure 3. Fuel Consumption: Prime mover, boiler, and system

The monthly system electrical, thermal, and total efficiencies are given in Figure 4 . The thermal efficiencies are between $35 \%$ and $48 \%$, and the electrical efficiency fluctuates from $26 \%$ to $35 \%$. The reduction in the electrical efficiency during the summer months is caused by the operation of a boiler to meet the high cooling needs that cannot be met by the recovered thermal energy of the engine, thus increasing the total energy input to the system. An examination of the system schematic in Figure 1 reveals that the absorption chiller is used for cooling which increases the energy losses of the system during the summer months. However, during the winter months, the heated water bypasses the absorption chiller and is sent straight to the heating coil when heating is required which minimized the energy losses due to thermal energy transport. The maximum system total efficiency is approximately $78 \%$ and occurs in the colder months when the thermal loads nearly match the recoverable heat available from the prime mover. The highest total efficiencies from Figure 4 coincide with the lowest boiler fuel consumption requirements from Figure 3 in the months of November through March. 


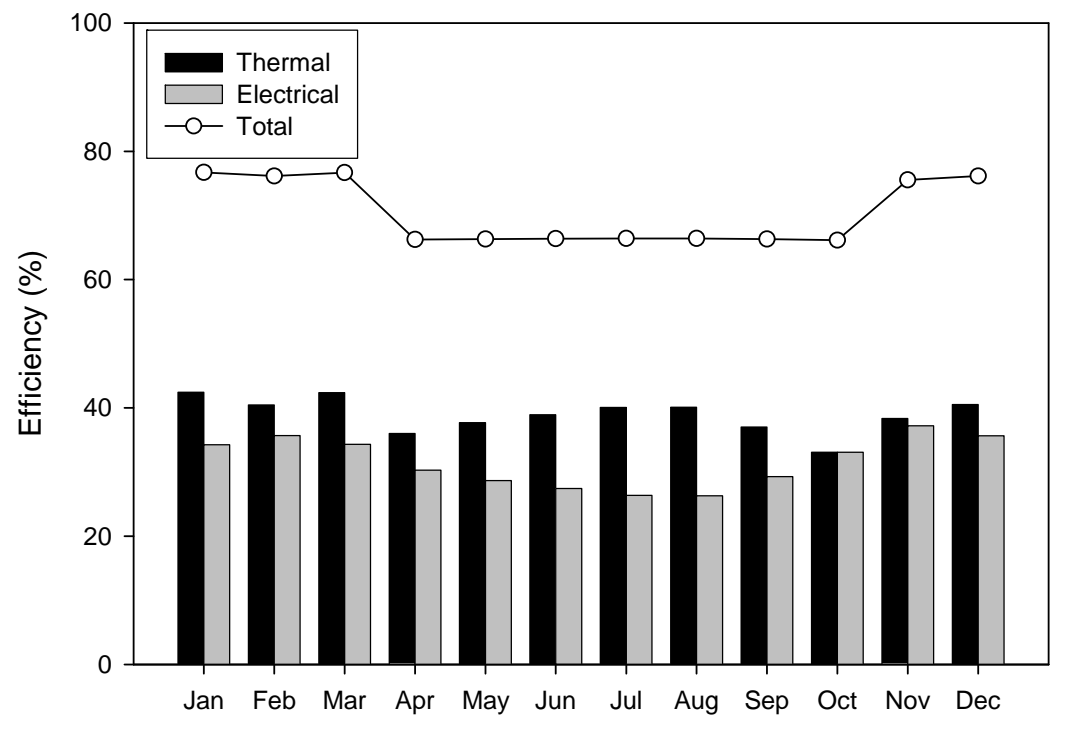

Figure 4. Case Study: Micro-CHP System Efficiencies

\section{Model Uncertainly Analysis}

Using the model input uncertainties from Table 1, the uncertainty in the simulations results for the predicted total system efficiency has a yearly average of $2.8 \%$. The average uncertainty of the predicted fuel consumption was $14.5 \mathrm{~kg} /$ month. As shown in Table 1, there were many different variables included in the uncertainty analysis associated with the simulation results. However, only the variables which contributed significantly to the uncertainty in the system performance (variables with significant UPC values) are presented in the results. Comparison of the uncertainty results were performed for the critical months of January (heating) and August (cooling).

Table 1. Simulation data used in the model uncertainty calculations

\begin{tabular}{lll}
\hline Variable & Value & Uncertainty \\
\hline Engine Speed, $N$ & $1800 \mathrm{rpm}$ & $10 \mathrm{rpm}$ \\
Compression Ratio, $r v$ & 8.5 & 0.5 \\
Initial Pressure, $P_{I}$ & $101 \mathrm{kPa}$ & $1 \mathrm{kPa}$ \\
Initial Temperature, $T_{I}$ & $298 \mathrm{~K}$ & $2 \mathrm{~K}$ \\
Air Fuel Ratio, AF & 16 & 1 \\
Displacement Volume, $V_{d}$ & $0.00182 \mathrm{~m}^{3}$ & $0.0001 \mathrm{~m}^{3}$ \\
Chiller COP & 0.75 & 0.05 \\
Boiler Efficiency, $\eta_{\text {boiler }}$ & 0.9 & 0.05 \\
Generator Efficiency, $\eta_{\text {generator }}$ & 0.85 & 0.05 \\
Mechanical Efficiency, $\eta_{\text {mech }}$ & 0.9 & 0.05 \\
Lower Heating Value, LHV & $46500 \mathrm{~kJ} / \mathrm{kg}$ & $230 \mathrm{~kJ} / \mathrm{kg}$ \\
Pipe Loss Coefficient, $\xi$ & 0.9 & 0.05 \\
Heat Exchanger Efficiency, $\varepsilon$ & 0.75 & 0.05 \\
Electricity per Month & $7 \mathrm{kWh}$ & $0.5 \mathrm{kWh}$ \\
Ratio of Specific Heats, $\gamma$ & 1.36 & 0.03 \\
\hline
\end{tabular}


Tables 2 and 3 present the UMF's and UPC's for each variable for the system total efficiency per month for the model input nominal values and associated uncertainties presented in Table 1. The results given in Table 2 show that for the month of January, the generator efficiency followed by the prime mover mechanical efficiency have the highest UMF. Similarly, for the month of August, the generator efficiency presents the highest UMF followed by the chiller COP, in that order. The UPC results presented in Table 3 are illustrated in Figure 5 for the months of January and August. These results show that for the month of January, the uncertainty in the simulation results for the system total efficiency is most influenced by the generator efficiency, followed by the heat exchanger efficiency, in that order. For the summer month of August, the uncertainty in the simulation results for system total efficiency is most influenced by the chiller COP followed by generator efficiency. In this particular case, the variable with the highest UMF (generator efficiency) also exhibited the highest UPC for the system total efficiency for the month of January. The uncertainty analysis for the simulation results of the total system efficiency shows that the generator efficiency is an important parameter contributing significantly to the uncertainty in the simulation results during both winter and summer months. In addition, during the summer months when cooling is predominant, the COP plays an important role in the performance of the CHP system.

Tables 4 and 5 present the UMF's and UPC's for each variable associated with simulation results for the monthly fuel consumption of the micro-CHP system. Table 4 shows that for the month of January, the generator efficiency, the prime mover mechanical efficiency, and the heat exchanger effectiveness show the highest UMF. For the month of August, the chiller COP is the variable with the highest UMF. The UPC results presented in Table 5 are illustrated in Figure 6 for the months of January and August. Figure 6 shows that for the month of January, the uncertainty in the simulation results for the fuel consumption is most influence by the heat exchanger effectiveness and the pipe loss coefficient, in that order. For the summer month of August, the uncertainty in the simulation results for the fuel consumption is most influence by the chiller COP followed by the heat exchanger effectiveness. An important fact must be pointed out that, for January, even though the generator efficiency and the prime mover mechanical efficiency show the highest UMF, they are not the major uncertainty contributors for the total fuel consumption. However, for August, the COP is the variable with the highest UMF and the highest UPC for the total fuel consumption. For the month of January, the CHP system basically operates under heating and power conditions. For that reason, the heat recovery is very important during this process. This is reflected in the uncertainty results that show that the heat exchanger effectiveness is the major contributor to the uncertainty in the simulation results, followed by all the possible losses in the piping system. For the month of August, the CHP system operates under cooling and power conditions. For that reason, the chiller coefficient of performance is the most dominant parameter during this time in terms of simulation uncertainty contributions. Of course, the heat exchanger effectiveness is also important since hot water is needed to operate the absorption chiller.

Using Equation 32, the model user is able to make predictions associated with the uncertainty of the system performance by simply changing the uncertainty associated with each parameter given in Table 1. In addition, the UMF and UPC values given in Tables 2 through 5 shed light on how each variable contributes to the overall uncertainty in the simulation results. With this information, the model user is able to make the best decision about which input parameters need to be measured with the most accuracy. 
Table 2. UMF's per month for the CHP total efficiency.

\begin{tabular}{|l|c|c|c|c|c|c|c|c|c|}
\hline Month & $\begin{array}{c}\text { Compression } \\
\text { Ratio, } \\
r_{v}\end{array}$ & $\begin{array}{c}\text { Ratio of } \\
\text { Specific } \\
\text { Heats, } \\
\gamma\end{array}$ & $\begin{array}{c}\text { Chiller } \\
\text { COP }\end{array}$ & $\begin{array}{c}\text { Boiler } \\
\text { Efficiency, } \\
\eta_{\text {boiler }}\end{array}$ & $\begin{array}{c}\text { Pipe Loss } \\
\text { Coefficient, } \\
\xi\end{array}$ & $\begin{array}{c}\text { Mechanical } \\
\text { Efficiency, } \\
\eta_{\text {mech }}\end{array}$ & $\begin{array}{c}\text { Generator } \\
\text { Efficiency, } \\
\eta_{\text {generator }}\end{array}$ & $\begin{array}{c}\text { Lower } \\
\text { Heating } \\
\text { Value, } \\
\text { LHV }\end{array}$ & $\begin{array}{c}\text { Heat } \\
\text { Exchanger } \\
\text { Efficiency, } \\
\varepsilon\end{array}$ \\
\hline Jan & -13.32 & -672.34 & 0 & -401.16 & -1106.55 & -1689.47 & -4485.50 & 0 & -1327.86 \\
\hline Feb & -13.23 & -668.23 & 0 & -271.48 & -1099.79 & -1679.17 & -4458.19 & 0 & -1319.77 \\
\hline Mar & -13.30 & -672.17 & 0 & -394.83 & -1106.25 & -1689.01 & -4484.35 & 0 & -1327.52 \\
\hline Apr & -9.15 & -461.60 & -1589.07 & -564.58 & -759.70 & -1159.90 & -3079.51 & 0 & -911.655 \\
\hline May & -8.76 & -443.11 & 1688.17 & -677.59 & -729.25 & -1113.41 & -2956.04 & 0 & -875.096 \\
\hline Jun & -8.49 & -428.24 & 1760.54 & -762.35 & -704.82 & -1076.11 & -2856.97 & 0 & -845.793 \\
\hline Jul & -8.19 & -414.28 & -1823 & -837.42 & -681.79 & -1040.97 & -2763.69 & 0 & -818.159 \\
\hline Aug & -8.19 & -413.59 & -1825.94 & -840.99 & -680.67 & -1039.24 & -2759.04 & 0 & -816.793 \\
\hline Sep & -8.92 & -450.72 & 1649.29 & -632.70 & -741.76 & -1132.53 & -3006.83 & 0 & -890.138 \\
\hline Oct & -9.67 & -489.02 & 1415.78 & -375.03 & -804.84 & -1228.84 & -3262.59 & 0 & -965.842 \\
\hline Nov & -13.15 & -663.46 & 0 & -144.62 & -1091.93 & -1667.19 & -4426.35 & 0 & -1310.35 \\
\hline Dec & -13.24 & -668.31 & 0 & -273.72 & -1099.91 & -1679.37 & -4458.69 & 0 & -1319.9 \\
\hline
\end{tabular}


Table 3. UPC's per month for the CHP total efficiency.

\begin{tabular}{|l|c|c|c|c|c|c|c|c|c|}
\hline Month & $\begin{array}{c}\text { Compression } \\
\text { Ratio, } \\
r_{v}\end{array}$ & $\begin{array}{c}\text { Ratio of } \\
\text { Specific } \\
\text { Heats, } \\
\gamma\end{array}$ & $\begin{array}{c}\text { Chiller } \\
\text { COP }\end{array}$ & $\begin{array}{c}\text { Boiler } \\
\text { Efficiency, } \\
\eta_{\text {boiler }}\end{array}$ & $\begin{array}{c}\text { Pipe Loss } \\
\text { Coefficient, } \\
\xi\end{array}$ & $\begin{array}{c}\text { Mechanical } \\
\text { Efficiency, } \\
\eta_{\text {mech }}\end{array}$ & $\begin{array}{c}\text { Generator } \\
\text { Efficiency, } \\
\eta_{\text {generator }}\end{array}$ & $\begin{array}{c}\text { Lower } \\
\text { Heating } \\
\text { Value, } \\
\text { LHV }\end{array}$ & $\begin{array}{c}\text { Heat } \\
\text { Exchanger } \\
\text { Efficiency, } \\
\varepsilon\end{array}$ \\
\hline Jan & 0.75 & 6.03 & 0.00 & 0.43 & 13.01 & 7.58 & 53.46 & 0.00 & 18.74 \\
\hline Feb & 0.76 & 6.04 & 0.00 & 0.20 & 13.04 & 7.60 & 53.58 & 0.00 & 18.78 \\
\hline Mar & 0.75 & 6.03 & 0.00 & 0.41 & 13.01 & 7.58 & 53.47 & 0.00 & 18.74 \\
\hline Apr & 0.48 & 3.81 & 35.97 & 1.13 & 8.22 & 4.79 & 33.77 & 0.00 & 11.84 \\
\hline May & 0.44 & 3.50 & 40.52 & 1.63 & 7.56 & 4.41 & 31.06 & 0.00 & 10.89 \\
\hline Jun & 0.41 & 3.27 & 43.99 & 2.06 & 7.05 & 4.11 & 28.96 & 0.00 & 10.15 \\
\hline Jul & 0.38 & 3.05 & 47.10 & 2.48 & 6.59 & 3.84 & 27.06 & 0.00 & 9.49 \\
\hline Aug & 0.38 & 3.04 & 47.25 & 2.51 & 6.57 & 3.83 & 26.97 & 0.00 & 9.46 \\
\hline Sep & 0.45 & 3.62 & 38.69 & 1.42 & 7.83 & 4.56 & 32.15 & 0.00 & 11.27 \\
\hline Oct & 0.53 & 4.29 & 28.65 & 0.50 & 9.26 & 5.40 & 38.04 & 0.00 & 13.33 \\
\hline Nov & 0.76 & 6.05 & 0.00 & 0.06 & 13.06 & 7.61 & 53.66 & 0.00 & 18.81 \\
\hline Dec & 0.76 & 6.04 & 0.00 & 0.20 & 13.04 & 7.60 & 53.58 & 0.00 & 18.78 \\
\hline
\end{tabular}


Table 4. UMF's per month for the CHP Fuel Consumption.

\begin{tabular}{|c|c|c|c|c|c|c|c|c|c|}
\hline Month & $\begin{array}{c}\text { Compression } \\
\text { Ratio, } \\
r_{v}\end{array}$ & $\begin{array}{c}\text { Ratio of } \\
\text { Specific } \\
\text { Heats, } \\
\gamma\end{array}$ & $\begin{array}{c}\text { Chiller } \\
\text { COP }\end{array}$ & $\begin{array}{c}\text { Boiler } \\
\text { Efficiency, } \\
\eta_{\text {boiler }}\end{array}$ & $\begin{array}{c}\text { Pipe Loss } \\
\text { Coefficient, } \\
\xi\end{array}$ & $\begin{array}{c}\text { Mechanical } \\
\text { Efficiency, } \\
\eta_{\text {mech }}\end{array}$ & $\begin{array}{c}\text { Generator } \\
\text { Efficiency, } \\
\eta_{\text {generator }}\end{array}$ & $\begin{array}{c}\text { Lower } \\
\text { Heating } \\
\text { Value, } \\
\text { LHV }\end{array}$ & $\begin{array}{c}\text { Heat } \\
\text { Exchanger } \\
\text { Efficiency, } \\
\varepsilon \\
\end{array}$ \\
\hline Jan & 42.99 & 2171.99 & 0 & 4179.28 & 11527.82 & 14687.78 & 14687.78 & 0.60 & 13833.38 \\
\hline $\mathrm{Feb}$ & 37.65 & 1902.72 & 0 & 2493.02 & 10098.68 & 12866.89 & 12866.89 & 0.48 & 12118.45 \\
\hline Mar & 44.99 & 2272.59 & 0 & 4305.18 & 12061.90 & 15368.23 & 15368.23 & 0.60 & 14474.25 \\
\hline Apr & 29.69 & 1500.25 & 16654.68 & 5917.45 & 7962.61 & 10145.30 & 10145.30 & 0.45 & 9555.162 \\
\hline May & 34.00 & 1717.44 & 21100.68 & 8469.91 & 9115.37 & 11614.03 & 11614.03 & 0.56 & 10938.44 \\
\hline Jun & 32.37 & 1635.47 & 21681.45 & 9388.97 & 8680.26 & 11059.67 & 11059.67 & 0.56 & 10416.32 \\
\hline Jul & 30.73 & 1552.79 & 22035.24 & 10122.51 & 8241.53 & 10500.65 & 10500.65 & 0.56 & 9889.849 \\
\hline Aug & 33.69 & 1701.91 & 24230.76 & 11160.77 & 9032.99 & 11509.07 & 11509.07 & 0.60 & 10839.58 \\
\hline Sep & 31.12 & 1572.50 & 18556.66 & 7118.99 & 8346.15 & 10633.95 & 10633.95 & 0.49 & 10015.40 \\
\hline Oct & 32.65 & 1649.56 & 15400.17 & 4079.68 & 8755.04 & 11154.95 & 11154.95 & 0.45 & 10506.05 \\
\hline Nov & 39.61 & 2001.08 & 0 & 1406.52 & 10620.70 & 13532.01 & 13532.01 & 0.51 & 12744.84 \\
\hline Dec & 39.46 & 1993.87 & 0 & 2633.77 & 10582.60 & 13483.43 & 13483.43 & 0.53 & 12699.13 \\
\hline
\end{tabular}


Table 5. UPC's per month for the CHP Fuel Consumption.

\begin{tabular}{|l|c|c|c|c|c|c|c|c|c|}
\hline Month & $\begin{array}{c}\text { Compression } \\
\text { Ratio, } \\
r_{v}\end{array}$ & $\begin{array}{c}\text { Ratio of } \\
\text { Specific } \\
\text { Heats, } \\
\gamma\end{array}$ & $\begin{array}{c}\text { Chiller } \\
\text { COP }\end{array}$ & $\begin{array}{c}\text { Boiler } \\
\text { Efficiency, } \\
\eta_{\text {boiler }}\end{array}$ & $\begin{array}{c}\text { Pipe Loss } \\
\text { Coefficient, } \\
\xi\end{array}$ & $\begin{array}{c}\text { Mechanical } \\
\text { Efficiency, } \\
\eta_{\text {mech }}\end{array}$ & $\begin{array}{c}\text { Generator } \\
\text { Efficiency, } \\
\eta_{\text {generator }}\end{array}$ & $\begin{array}{c}\text { Lower } \\
\text { Heating } \\
\text { Value, } \\
\text { LHV }\end{array}$ & $\begin{array}{c}\text { Heat } \\
\text { Exchanger } \\
\text { Efficiency, } \\
\varepsilon\end{array}$ \\
\hline Jan & 0.16 & 1.25 & 0.00 & 0.92 & 28.00 & 11.36 & 11.36 & 6.62 & 40.32 \\
\hline Feb & 0.16 & 1.27 & 0.00 & 0.43 & 28.44 & 11.54 & 11.54 & 5.65 & 40.96 \\
\hline Mar & 0.16 & 1.25 & 0.00 & 0.90 & 28.17 & 11.43 & 11.43 & 6.09 & 40.56 \\
\hline Apr & 0.07 & 0.55 & 54.00 & 1.70 & 12.34 & 5.01 & 5.01 & 3.53 & 17.78 \\
\hline May & 0.06 & 0.48 & 58.15 & 2.34 & 10.85 & 4.40 & 4.40 & 3.67 & 15.63 \\
\hline Jun & 0.05 & 0.44 & 61.15 & 2.87 & 9.80 & 3.98 & 3.98 & 3.62 & 14.11 \\
\hline Jul & 0.05 & 0.40 & 63.64 & 3.36 & 8.90 & 3.61 & 3.61 & 3.61 & 12.82 \\
\hline Aug & 0.05 & 0.40 & 63.88 & 3.39 & 8.88 & 3.60 & 3.60 & 3.41 & 12.78 \\
\hline Sep & 0.06 & 0.51 & 56.61 & 2.08 & 11.45 & 4.65 & 4.65 & 3.49 & 16.49 \\
\hline Oct & 0.08 & 0.67 & 46.27 & 0.81 & 14.96 & 6.07 & 6.07 & 3.54 & 21.54 \\
\hline Nov & 0.16 & 1.27 & 0.00 & 0.13 & 28.53 & 11.58 & 11.58 & 5.67 & 41.09 \\
\hline Dec & 0.16 & 1.26 & 0.00 & 0.44 & 28.29 & 11.48 & 11.48 & 6.17 & 40.73 \\
\hline
\end{tabular}




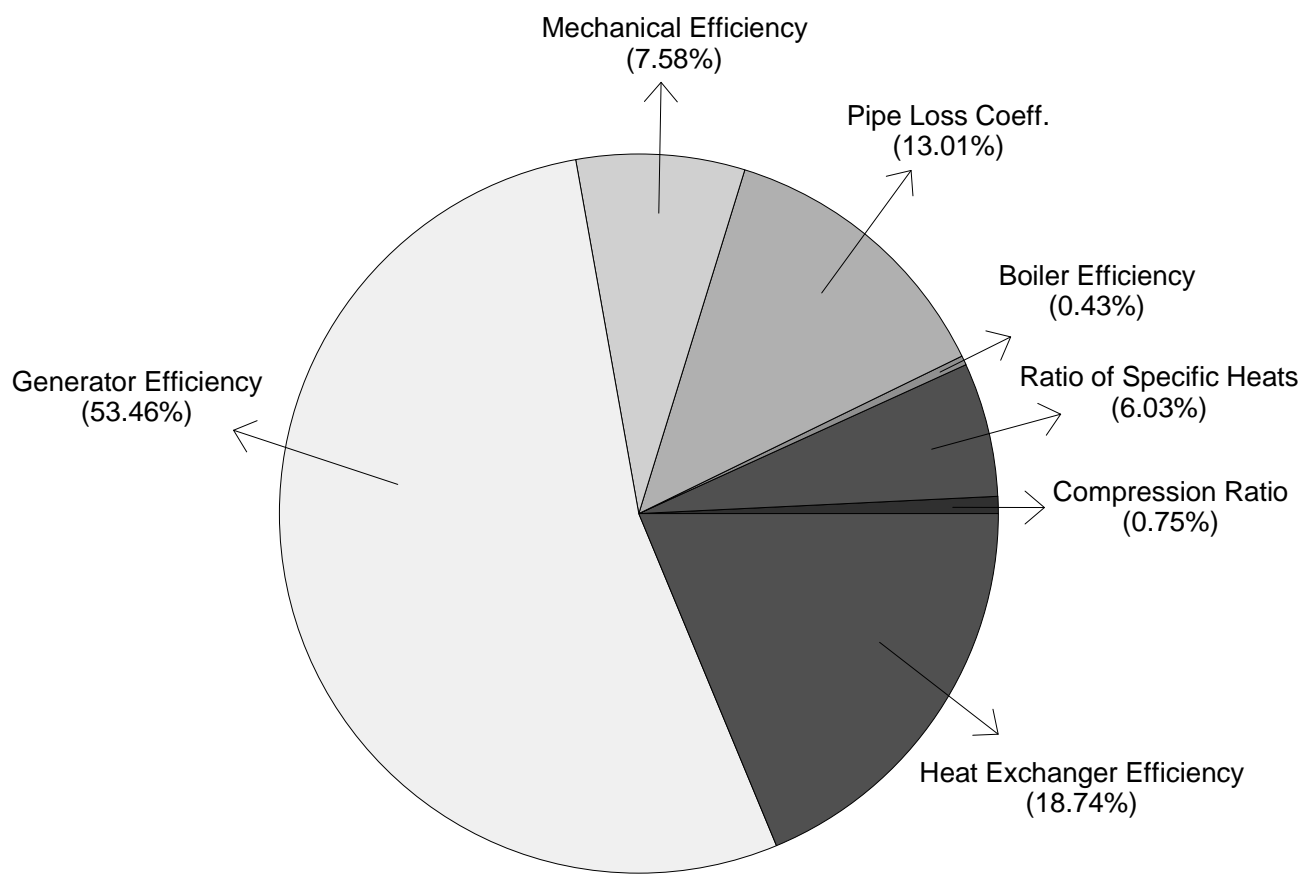

(a) January

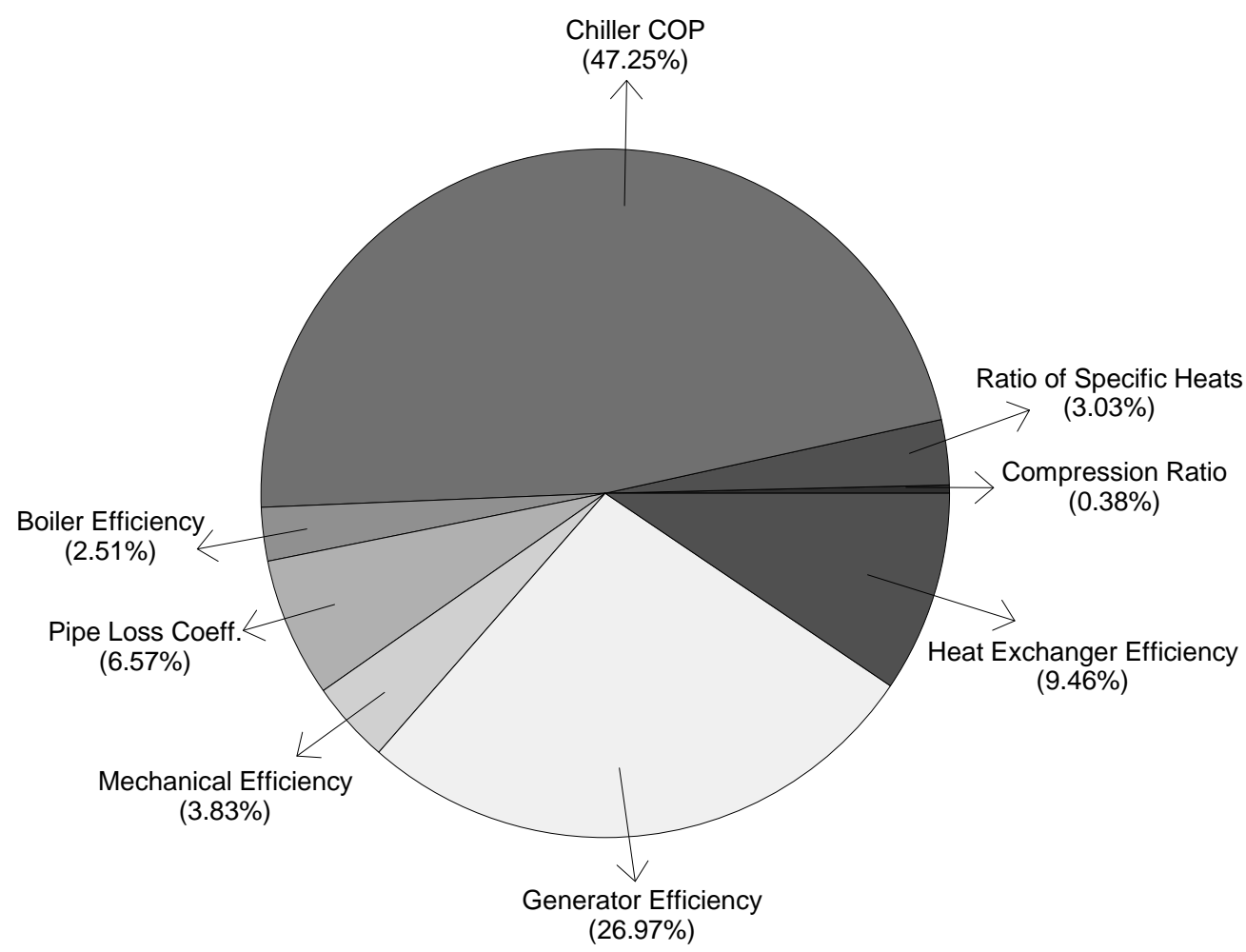

(b) August

Figure 5. UPC's distribution for the total system efficiency for the months of: (a) January and (b) August. 


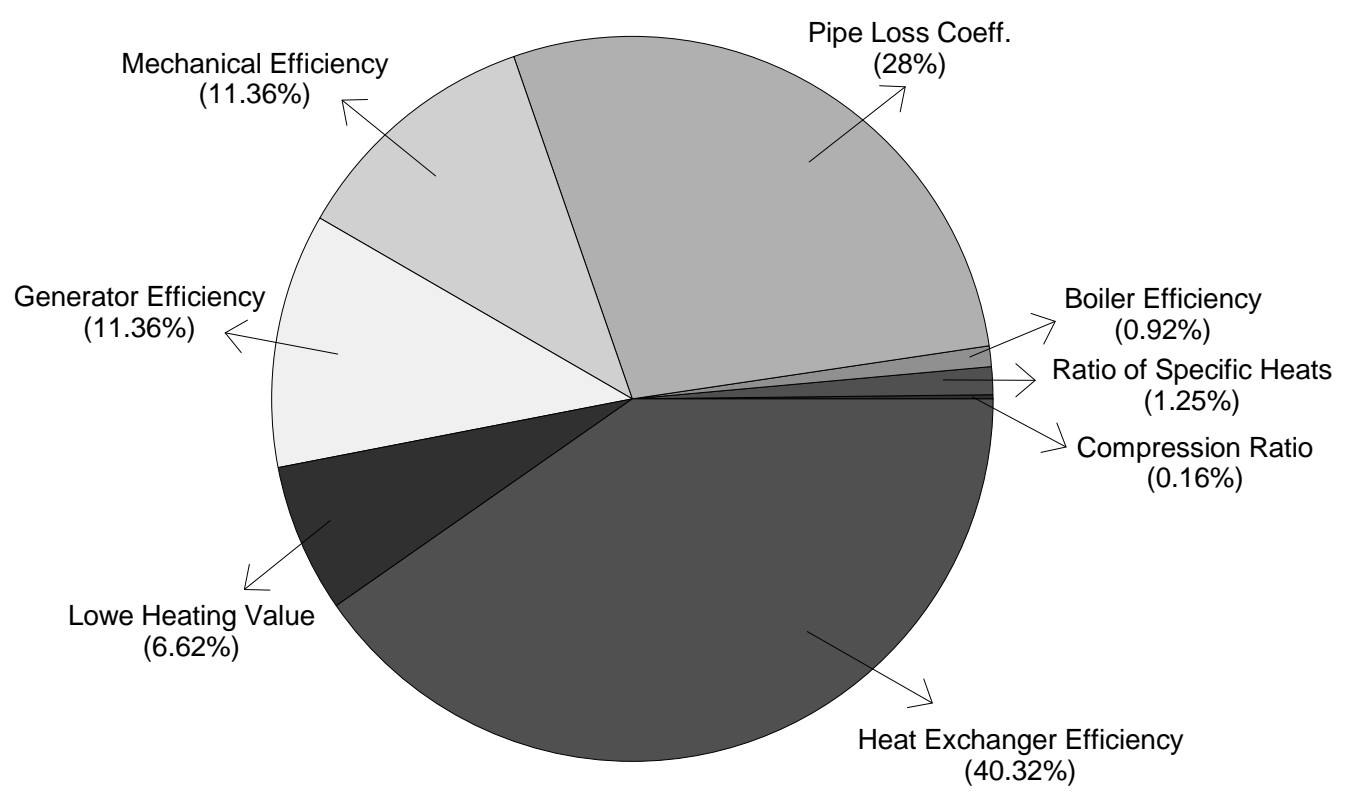

(a) January

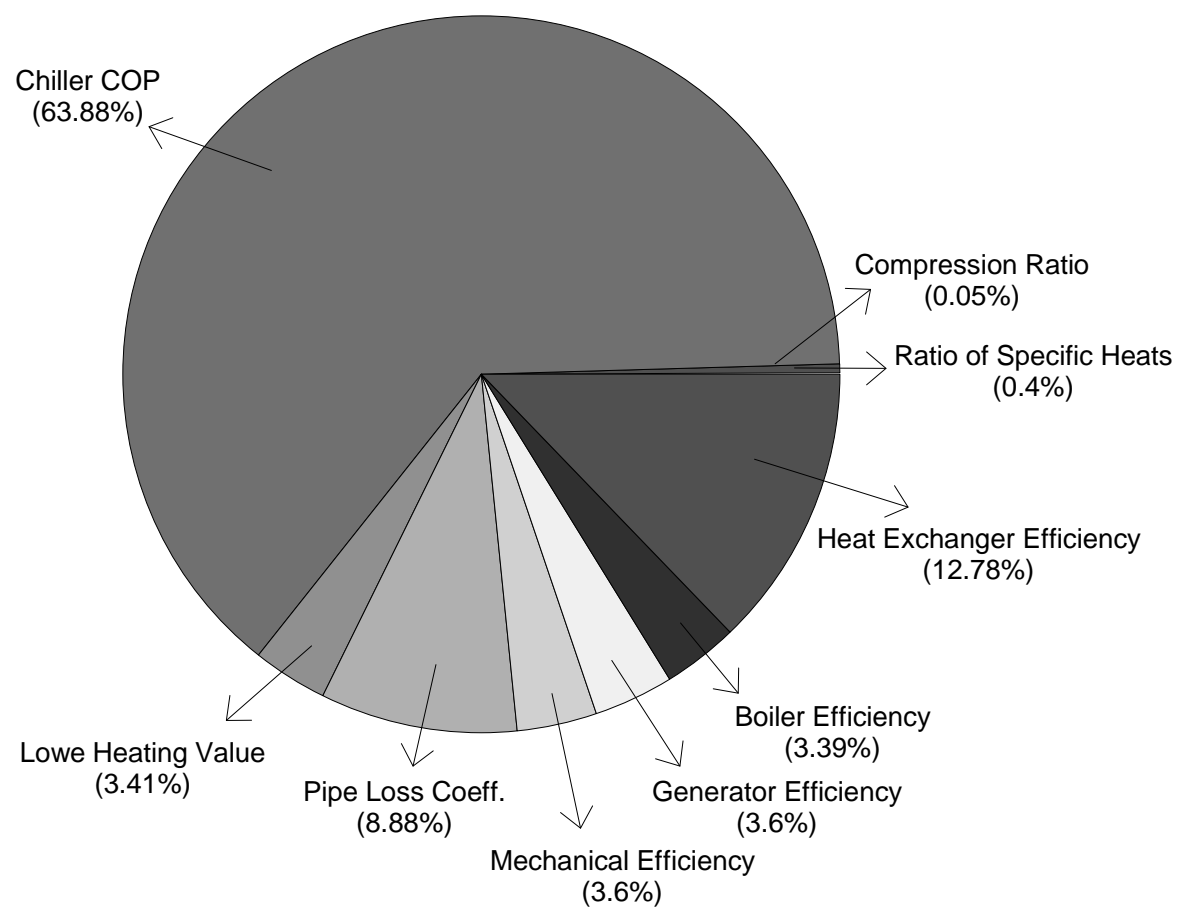

(b) August

Figure 6. UPC's distribution for the total fuel consumption for the months of: (a) January and (b) August 


\section{CONCLUSIONS}

A micro-CHP system model and its associated uncertainty are presented in this paper. A case study was used to demonstrate the developed model. For this case, the thermal efficiencies are between $35 \%$ and $48 \%$, the electrical efficiency fluctuates from $26 \%$ to $35 \%$, and the total system efficiencies between $64 \%$ and $78 \%$. The maximum system total efficiency is approximately $78 \%$ and occurs in the winter months when the thermal loads nearly match the recoverable heat available from the prime mover. The uncertainty in the simulation results for the predicted total system efficiency was calculated as $2.8 \%$, while the average uncertainty of the predicted fuel consumption was determined as $14.5 \mathrm{~kg} / \mathrm{month}$. The variables that have the highest influence on the uncertainty associated with the prediction of the system total efficiency per month are the generator efficiency and the heat exchanger effectiveness for the month of January. For the month of August, the chiller COP and generator efficiency are the major contributors to simulation uncertainty. The variables with the strongest influence on simulation uncertainty associated with the prediction of fuel consumption per month for the month of January are the heat exchanger effectiveness and the pipe loss coefficient. Moreover, for the month of August, the chiller COP and the heat exchanger effectiveness were the major contributors. The conclusion drawn from the detailed uncertainty analysis of the model simulation results show that special care must be taken when selecting equipment that most affects the performance of the micro-CHP system. Without a complete evaluation of the uncertainties associated with model input parameters, conclusions cannot be made as to how each parameter propagates through the model. This evaluation not only provides valuable information about the model itself, but also affects the economic footprint left by the construction of such a system. Furthermore, this examination lays the foundation upon which a quantitative $V \& V$ effort can begin to take shape.

\section{REFERENCES}

[1] Jalalzadeh-Azar, A., Slayzak, S., and Ryan, J., 2002, "Evaluation of Cooling, Heating, and Power (CHP) for Office Buildings," ASHRAE Transactions, 108 (1), pp. 1045-105

[2] Frey., H.C., Quantitative analysis of uncertainty and variability in environmental policy making. Available from: Directorate for Science and Policy Programs, American Association for the Advancement of Science, $1333 \mathrm{H}$ Street, NW, Washington, DC, September 1992.

[3] Moran, A., Mago, P.J., and Chamra, L.M., "Thermoeconomic Modeling of Micro-CHP (Micro-Cooling, Heating, and Power) for Small Commercial Applications." International Journal of Energy Research, accepted for publication.

[4] Pulkrabek, W. W. Engineering Fundamentals of the Internal Combustion Engine. $2^{\text {nd }}$ ed. Upper Saddle River, NJ: Prentice-Hall, 2004.

[5] Incropera, F. P., and Dewitt, D. P. Fundamentals of Heat and Mass Transfer. $5^{\text {th }}$ ed. New York: Wiley \& Sons, 2002.

[6] Kuehn, T. H., Ramsey, J. W., and Threlkeld, J. L. Thermal Environmental Engineering. $3^{\text {rd }}$ ed. Upper Saddle River, NJ: Prentice Hall, 1998.

[7] Onovwiona, H. and Ugursal, V. "Residential cogeneration systems: a review of the current technology," Renewable and Sustainable Energy Reviews, 10 (2006): 389-431. 
[8] Coleman, H.W., and Steele, W.G., 1999, Experimentation and Uncertainty Analysis for Engineers, Second Edition, John Wiley \& Sons, Inc., New York, NY.

[9] TRACE 700 Load Design. Trane. Available at www.trane.com/commercial/software/load700/

[10] Priedeman, D.K., Performance of a Residential-Sized GAX Absorption Chiller. Journal of Energy Resources Technology, 123, No. 3, pp. 236-241, September 2001

[11] Tomasz M. Mróz, T.M., Thermodynamic and economic performance of the $\mathrm{LiBr}-\mathrm{H}_{2} \mathrm{O}$ single stage absorption water chiller. Applied Thermal Enqineering. Volume 26, Issues 17-18, December 2006, Pages 2103-2109,

[12] Misra, R.D., Sahoo, P.K., Sahoo, S., and Gupta, A. Thermoeconomic optimization of a single effect water/LiBr vapour absorption refrigeration system. International Journal of Refrigeration. 26 (2003) 158-169

[13] Lamp, P., Schweigler, C., and Ziegler, F. Opportunities for sorption cooling using low grade heat. Applied Thermal Enqineering. Volume 18, Issues 9-10, 1 September 1998, Pages 755-764

[14] Jarnagin, R.E. Heat Recovery from Air Conditioning Units. This document is Fact Sheet EES-26, a series of the Florida Energy Extension Service, Florida Cooperative Extension Service, Institute of Food and Agricultural Sciences, University of Florida.

[15] Kubesh, J.T., Uncertainty in the Determination of Thermal Efficiency in Natural Gas Engines, ICEF2002-522, Proceedings of the 2002 Fall Technical Conference of the ASME Internal Combustion Engine Division, V.W. Wong, Editor, 2002.

\section{METHODOLOGY TO PERFORM A NON-CONVENTIONAL EVALUATION OF COOLING, HEATING, AND POWER SYSTEMS}

\section{INTRODUCTION}

The increasing demand for electrical power as well as energy for heating and cooling of buildings is a growing worldwide concern. Economical, environmental, political, and logistical problems associated with increasing centralized electrical power production are becoming more difficult to overcome. In addition, as consumers continue to be more involved and to develop more understanding about energy choices, the demand for technology that better meets their energy needs will increase.

Combined Cooling, Heating, and Power (CHP) generation systems have been widely recognized as a key alternative for heat and electricity generation because of their outstanding energy efficiency, reduced environmental emissions, and relative independence from centralized power grids. CHP is a promising technology for increased energy efficiency through the use of distributed electric and thermal energy delivery systems at or near end-user sites. Also, CHP systems promote energy reliability and self-sufficiency for many residential and commercial applications.

As much as two thirds of the energy contained in the fuel used for electrical generation ends up as waste heat released to the environment. CHP systems tap onto this waste heat by using it for dehumidification, cooling, and heating, which results in more efficient use of the energy contained in the fuel (see Figure 1). The increased energy efficiency and the potential for 
using cleaner (natural gas and propane) and renewable (biomass) resources yields significantly reduced emissions of pollutants from CHP systems when compared to conventional systems. Extensive use of CHP technology will diminish the susceptibility to blackouts, generally associated with centralized power distribution, which can cripple large geographical areas in the country.

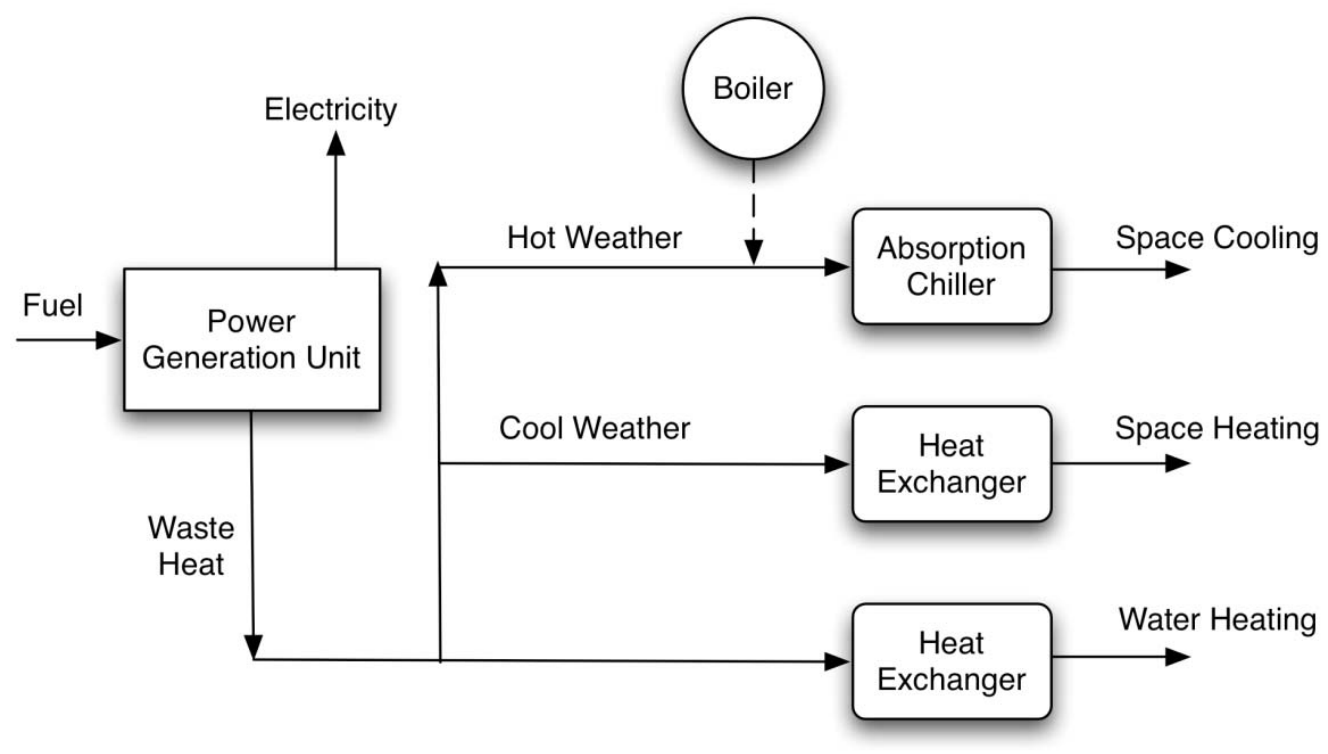

Figure 1. Schematic of a CHP system

Several researchers have investigated and reported the economic benefits of using CHP systems. Some of them are: Newborough [1]; Keppo and Savola [2]; Jablko et al., [3]; Tucker [4]; De Paepe et al., [5]; Zoog [6]; Mago et al., [7]. Although CHP technology seems to be economically feasible, the evaluation and comparison of CHP systems cannot be restricted to economical considerations only. A non-conventional evaluation of CHP systems, based on noneconomical aspects, will show the additional benefits that can be obtained from this technology. As homeowners, customers, investors, and the government continue to be more involved and to develop more understanding about energy choices, a more comprehensive evaluation, especially a non-conventional one, of CHP technologies is required.

This paper concentrates on two aspects of a non-conventional CHP evaluation: energyefficient buildings and emission of pollutants. The first aspect includes an evaluation based on energy-efficient buildings, which is associated with energy conservation and improvement of the building energy performance rating for energy programs like Energy Star [8] and Leadership in Energy and Environmental Design (LEED) [9]. Using CHP systems will help building owners to reap the benefits from these energy programs while improving the overall energy use and energy cost.

The second aspect is focused on the environmental benefits concerned with the greenhouse gas emission of carbon dioxide $\left(\mathrm{CO}_{2}\right)$, nitrogen oxides $\left(\mathrm{NO}_{\mathrm{x}}\right)$, and sulfur dioxide $\left(\mathrm{SO}_{2}\right)$ that can be obtained from the use of CHP systems. The use of CHP systems reduces the electric energy consumption from the grid, which comes from a generation process that includes coal and other fossil fuels in the fuel mix. The grid-electric energy is substituted by electricity from the power generation unit of the CHP, which can use environmentally friendly fuels such as 
natural gas, propane, and biofuels. The high-energy efficiency of CHP systems, along with the use of less polluting fuels, translates into reduction of pollutants, which gives this technology importance beyond the economics.

The main objective of this investigation is to develop a methodology to perform a nonconventional evaluation of CHP systems based on energy-efficient buildings and emission of pollutants. This methodology can be used to show and to quantify the benefits of this technology beyond standard economic analyses.

$\begin{array}{ll}\text { NOMENCLATURE } \\ \text { CHP } & \text { Combined cooling, heating, and power system } \\ C O P & \text { Coefficient of performance } \\ D D & \text { Degree-days } \\ \text { DG } & \text { Distributed generation } \\ E & \text { Electric energy } \\ \text { PGU } & \text { Power generation unit } \\ Q & \text { Energy (heat) from fuel use } \\ \text { Ton } & \text { Tons of cooling } \\ \text { Symbols } & \\ \eta & \text { Efficiency } \\ f & \text { Fraction } \\ + & \text { Values }>0 \\ \text { Subscripts } & \\ b & \text { Boiler } \\ c & \text { Cooling } \\ c h & \text { Absorption chiller } \\ e & \text { Electric, electricity } \\ g r i d & \text { Electric grid } \\ H & \text { Heat input } \\ h & \text { Heating, space and water } \\ m & \text { Monthly } \\ P G U & \text { Power generation unit } \\ R & \text { Heat recovered } \\ s & \text { Space } \\ t a c & \text { Thermally activated components } \\ v c & \text { Vapor compression system } \\ w & \text { Water } \\ y r & \text { Yearly } \\ & \end{array}$

\section{METHODOLOGY}

This section of the paper presents a methodology to perform a non-conventional evaluation of CHP Systems. This methodology is divided in three parts: energy consumption patterns, Energy Star rating, and emission of pollutants.

\section{Methodology to Determine the Energy Consumption Patterns}

For CHP systems, the energy consumption patterns are related to the total electric energy 
use, the portion of the electrical energy use required for cooling, and the heat required for space and water heating. The overall effect of a CHP system on the building energy performance depends on the energy consumption patterns, and these patterns are function of building operation and climate conditions. The methodology presented here allows estimating the annual energy consumption to perform an evaluation of CHP systems based on Energy Star rating and emission of pollutants. Since the actual building energy use can be known from monthly utility bills, the methodology described in this section is based on monthly energy consumptions. In order to account for the size of the power generation unit (PGU), the methodology considers different fractions of the electric energy that would be supplied by the PGU. The methodology presented here considers two cases. The first case is when the building monthly energy consumption patterns are known, and the second case is when the building annual energy consumption patterns are known.

\section{Case I: Building Monthly Energy Consumption Patterns Known}

Building monthly energy patterns can be estimated using energy bills, although energy consumption from commissioning is desired. In either case, information on electric energy use other than for cooling, electric energy use for cooling, and heat for space and water heating must be known.

1. Monthly Energy Patterns.

Define the actual building monthly energy consumption components: electric energy use other than for cooling system, $E_{m}$; electric energy use by the cooling system, $E_{c, m}$; and energy use (heat from fuel) for space and water heating, $Q_{h, m}$.

\section{Size of the Power Generation Unit (PGU).}

The size of the PGU is considered based on a fraction, $f_{e}$, of the annual total electric energy use, $E_{y r}$, and distributed on an average monthly electric energy produced by the PGU, $E_{P G U, m}$, as

$$
E_{P G U, m}=\frac{f_{e} E_{y r}}{12} .
$$

The methodology uses the average PGU electric energy output because it is expected that the PGU runs at the same capacity each month. To account for the PGU size on the overall performance, different values of $E_{P G U, m}$ should be considered.

3. Power Generation Unit Fuel Use.

The monthly fuel consumption of the PGU, $Q_{H, m}$, is evaluated as

$$
Q_{H, m}=\frac{E_{P G U, m}}{\eta_{P G U}},
$$

where $\eta_{P G U}$ is the power generation unit efficiency

Since this methodology uses building monthly energy consumption patterns, it considers that the PGU runs at full load during the CHP operation to satisfy the electric energy use. However, if more accurate analysis is required, curves for fuel consumption and efficiency for partial load can be considered

\section{Chiller Energy Use.}


CHP systems have the advantage that they can use waste heat to run an absorption chiller for space cooling. However, when the amount of heat recovered is not sufficient to satisfy the heat required for the absorption chiller to handle the cooling load, a backup boiler must be used. To estimate the monthly energy (heat) consumption by the absorption chiller operation, $Q_{c h, m}$, it is necessary to know the relation between the energy (heat input) required for an absorption chiller to handle the cooling load and the energy (electricity) consumed by a vapor compression system needed to handle the same cooling load. This relation can be estimated using the vapor compression system and the absorption chiller coefficients of performance. Then the monthly energy consumption by the absorption chiller operation, $Q_{c h, m}$ is estimated as

$$
Q_{c h, m}=E_{c, m}\left(\frac{C O P_{v c}}{C O P_{c h}}\right) .
$$

\section{Heat Recovering.}

From a first law of thermodynamic analysis for an internal combustion engine and heat exchangers (thermal activated components), the monthly thermal energy that can be recovered from the system, $Q_{R, m}$, is determined as

$$
Q_{R, m}=E_{P G U, m} \frac{\eta_{t a c}\left(1-\eta_{P G U}\right)}{\eta_{P G U}},
$$

where $\eta_{t a c}$ is the overall thermal energy efficiency for the thermal activated components. For those cases when thermal energy recovered is greater than the thermal energy consumption, the recovered heat will be considered equal to the thermal energy consumption.

\section{Heat Recovered Available for Heating.}

If the heat recovered is greater than the heat required for the chiller, additional available heat can be used for space or water heating, $Q_{R a, m}$. This heat can be estimated as

$$
Q_{R a, m}^{+}=Q_{R, m}-Q_{c h, m} .
$$

If the values in Equation (5) are negative, additional heat supply by a backup boiler is required to operate the absorption chiller.

7. Boiler Fuel Consumption.

For monthly basis, the fuel consumption by the boiler, $Q_{b, m}$, is estimated as

$$
Q_{b, m}^{+}=\frac{Q_{c h, m}-Q_{R, m}}{\eta_{b}},
$$

where $\eta_{b}$ is the boiler thermal efficiency.

8. Monthly Fuel Energy Use.

The energy consumption from the fuel is expressed as

$$
Q_{m}=Q_{h, m}+Q_{H, m}+Q_{b, m}-Q_{R a, m} \text {. }
$$




\section{Annual Energy Use.}

The grid electric energy use and the fuel energy use must be computed. This methodology considers that the total cooling load is handled by the CHP system.

\section{Case II: Building Annual Energy Consumption Known}

When only the annual building consumption is known, the monthly energy consumption can be estimated using the Monthly Degree-Days method presented in ASHRAE [10].. The degree-days method is related to the space heating and space cooling and does not allow having both for the same month. To account for any water heating use when space heating is not required, this methodology uses the heating degree-days to estimate the fuel energy consumption for water heating even when space cooling degree-days exists.

The Monthly Degree-Days method can be applied as follows:

monthly heating degree-days

$$
D D_{h}\left(t_{b a l}\right)=\sigma_{m} N^{1.5}\left[\frac{\phi_{h}}{2}+\frac{\ln \left(e^{-a \phi_{h}}+e^{a \phi_{h}}\right)}{2 a}\right],
$$

monthly cooling degree-days

$$
D D_{c}\left(t_{b a l}\right)=\sigma_{m} N^{1.5}\left[\frac{\phi_{c}}{2}+\frac{\ln \left(e^{-a \phi_{c}}+e^{a \phi_{c}}\right)}{2 a}\right],
$$

where $a=1.698 \sqrt{\text { day/month }}, \sigma_{m}$ is the standard deviation for each month, $N$ is the number of days in the month, $\phi$ is a normalized temperature, and $t_{b a l}$ is the balance point temperature.

The monthly heating degree-days for space heating are determined as

$$
\begin{cases}\text { if } \bar{t}_{o}>t_{b a l} & \left(D D_{h}\right)_{s}=0 \\ \text { if } \bar{t}_{o}<t_{b a l} & \left(D D_{h}\right)_{s}=D D_{h}(\text { Equation 8), }\end{cases}
$$

where $\bar{t}_{o}$ is the monthly average ambient temperature.

The monthly heating degree-days for water heating are determined as

$$
\left(D D_{h}\right)_{w}=D D_{h} \text {. }
$$

The monthly cooling degree-days for space cooling are determined as

$$
\begin{cases}\text { if } \bar{t}_{o}<t_{b a l} & \left(D D_{c}\right)_{s}=0 \\ \text { if } \bar{t}_{o}>t_{b a l} & \left(D D_{c}\right)_{s}=D D_{c} \text { (Equation 9). }\end{cases}
$$

The normalized temperature for heating and cooling are

$$
\text { for heating } \quad \begin{aligned}
\phi_{h} & =\frac{t_{b a l}-\bar{t}_{o}}{\sigma_{m} \sqrt{N}}, \\
\text { for cooling } & \phi_{c}=\frac{\bar{t}_{o}-t_{b a l}}{\sigma_{m} \sqrt{N}} .
\end{aligned}
$$

The monthly energy use for space heating is estimated as 


$$
Q_{h s, m}=\frac{Q_{h s, y r}\left(D D_{h}\right)_{s}}{\sum_{1}^{12}\left(D D_{h}\right)_{s}},
$$

where $Q_{h s, y r}$ is the building annual energy use for space heating.

The monthly energy use for water heating is estimated as

$$
Q_{h w, m}=\frac{Q_{h w, y r}\left(D D_{h}\right)_{w}}{\sum_{1}^{12}\left(D D_{h}\right)_{w}},
$$

where $Q_{h w, y r}$ is the building annual energy use for water heating.

The monthly energy use for space cooling is estimated as

$$
Q_{c, m}=\frac{Q_{c, y r}\left(D D_{c}\right)_{s}}{\sum_{1}^{12}\left(D D_{c}\right)_{s}},
$$

where $Q_{c, y r}$ is the building annual energy use for space cooling.

Once the actual building monthly energy consumption patterns have been estimated from the building annual energy consumption, the same methodology described in Case I is applied to find the energy consumption patterns when a CHP system is used. It is important to mention here that the methodology described in Case I is not limited to monthly basis energy consumptions. If weekly, daily, or hourly building energy consumption is used, the results obtained from this methodology will be more accurate.

\section{Methodology to Determine the Energy Star Rating}

CHP systems can improve the energy performance of a building, which can be evaluated using the Energy Star rating. Complete information about the Energy Star program and the Energy Star rating can be found in [8]. This program focuses on homes and business. For business Energy Star program offers energy management strategies and tools that help to improve and track energy performance. To assess energy performance for design projects and major building renovations, the program offers a web-based tool called Target Finder [11]. This tool rates the level of energy performance of a building on a 100 scale. To estimate how much energy a building would use at each level of performance, statistical analysis on the data gathered by the Department of Energy's Energy Information Administration is used by the tool. A building achieving a rating of 75 or higher and with a healthy and productive indoor air environment, consistent with industry standards, is eligible to receive the Energy Star label. According to the program, displaying an ENERGY STAR plaque conveys superior performance to tenants, customers, and employees. The building actual source energy data are weather normalized, which allows assessing the building performance relative to the typical weather for the corresponding region. As a national program for protecting the environment through superior energy efficiency, Energy Star uses source energy as the basis for benchmarking commercial building energy performance. Source energy includes the energy consumed at the building itself, or the site energy, plus the energy used to generate, transmit, and distribute the site energy. 
Target Finder requires building information to perform the rating. The required information is explained in details in Steps 1 through 3. In the last step, Step 4, the Energy Star rating of the actual building energy performance can be compared with the energy performance when a CHP system is used. The steps required to determine the rating using Target Finder are described below:

1. Facility Information: complete the following information required by Target Finder: Zip Code, Facility Name, City, and State. The Zip Code is used to determine the climate conditions that the building would experience in a normal year and to estimate how much energy is used at the source according with the energy fuel mix typical in the region specified by the zip code.

2. Facility Characteristics: Complete the information required by Target Finder related to the space type, which can be classified as Primary Space Type and Secondary Space Type. For each space type general information is required. For example, for general offices the tool requires the gross floor area, occupants, number of PCs, and operating hours/week.

3. Estimated Design Energy: In this part the annual energy consumption must be introduced. The tool allows accounting for two types of energy sources. The energy sources considered by the tool are: electricity, natural gas, fuel oil (No. 1), fuel oil (No. 2), fuel oil (No. 4), fuel oil (No. 5 and No. 6), steam, chilled water, wood, propane, liquid propane, kerosene, diesel (No. 2), coal (anthracite), coal (bituminous), and coke. A menu with appropriate units is available for each energy source.

4. Comparing Rating: The tool must be run with the same data for the Facility Information and the Facility Characteristics, but the Estimated Design Energy must account for the variation of the annual energy use without and with the CHP system. The Energy Star rating is found first with the actual building energy consumption and then with the estimated annual energy consumption obtained with the methodology described before. The variation in the rating (points) will give the benefits of CHP systems in the Energy Star rating.

\section{LEED Rating}

If energy efficiency is the primary goal, the Energy Star certification can be achieved with the use of CHP systems. When other aspects such as sustainability are of interest, CHP systems can be important contributors to achieve a Leadership in Energy and Environmental Design (LEED) certification. Complete information about the LEED Green Building Rating System can be found in [9]. To achieve LEED certification, buildings must meet all prerequisites in the Rating System and a minimum of 32 points. LEED for Existing Buildings (LEED-EB) ratings are awarded according to the following point thresholds: Certified 32-39 points, Silver 40-47 points, Gold 48-63 points, and Platinum 64-85 points [12]. The categories that are evaluated and the respective possible points are: Sustainable Sites (14 points), Water Efficiency (5 points), Energy and Atmosphere (23 points), Materials and Resources (16 points), Indoor Environmental Quality (22 points), and Innovation in Upgrades, Operations and Maintenance (5 points). For the Energy and Atmosphere category, Credit 1 Optimize Energy Performance has the greater weight with 10 points and is based on Energy Star rating according with Table 1. An Energy Star score of 63 points achieves 1 LEED point and increases linearly up to 10 LEED points for a score of 99 on the Energy Star scale. 
To evaluate the contribution of CHP systems in the LEED Rating the following steps are recommended:

1. Score of the Energy Star Rating.

The steps of the Energy Star Rating must be followed in order to obtain the score.

2. LEED Points.

Use Table 1 to obtain the points for the new LEED Rating. Compare the new LEED Rating with the one obtained with the actual building energy consumption (without a CHP system). The variation on the rating will give the benefits of the use of CHP systems in the LEED Rating.

Table 1. Points earned for LEED rating from Energy Star rating [9]

\begin{tabular}{cc}
\hline Energy Star rating & LEED-EB Points \\
\hline 63 & 1 \\
67 & 2 \\
71 & 3 \\
75 & 4 \\
79 & 5 \\
83 & 6 \\
87 & 7 \\
91 & 8 \\
95 & 9 \\
99 & 10 \\
\hline
\end{tabular}

\section{Methodology to Determine the Emission of Pollutants}

To estimate reduction of emission of pollutants from the use of CHP systems, the energy consumption is used to estimate the amount of pollutants by using emission factors. Emission factors account for the average emission rate of pollutants based on the energy obtained from burning fuels. The pollutants considered in this methodology are carbon dioxide $\left(\mathrm{CO}_{2}\right)$, nitrogen oxides $\left(\mathrm{NO}_{\mathrm{x}}\right)$, and sulfur dioxide $\left(\mathrm{SO}_{2}\right)$. Although other pollutants could be obtained from the combustion process of fossil fuels, for simplification purposes this methodology only consider the pollutants evaluated by the DOE tool Power Profiler [13] used to estimate the emission of pollutants from the electric energy use. The steps required to determine the reduction of pollutants from the use of CHP systems are described below:

1. Energy Consumption.

Define the actual building energy consumption (related to the site energy) and the estimated building energy consumption when a CHP system is used.

\section{Emissions from Electricity.}

For electricity, pollutants are estimated by means of the emission factors used internally by the Web-based tool Power Profiler [13]. This tool allows users to determine specific impacts of air emissions associated with their consumption of electricity based on the actual 
monthly use or average monthly use. This tool requires a Zip Code to show the electric distribution utilities in that region grid, and based on the fuel mix used to generate electricity in that region. The results given by Power Profiler include an adjustment of 9 percent for line losses. To find the emission of $\mathrm{CO}_{2}, \mathrm{NO}_{x}$, and $\mathrm{SO}_{2}$, Power Profiler must be run for the building actual energy consumption and for the building energy consumption when a CHP system is used.

\section{Emissions from Fuels.}

Different emission factors are required for each different fuel. This study focuses only on natural gas. Therefore, pollutants are estimated using the emission factors presented in Table 2 [14]. However, the same methodology can be applied for different fuels using the corresponding emission factors.

Table 2. Natural gas emission factors by energy consumed

\begin{tabular}{lc}
\hline Pollutant & $\mathrm{kg} / \mathrm{MWh}$ \\
\hline Carbon Dioxide $\left(\mathrm{CO}_{2}\right)$ & 181.1 \\
Nitrogen Oxides $\left(\mathrm{NO}_{\mathrm{x}}\right)$ & 0.1424 \\
Sulfur Dioxide $\left(\mathrm{SO}_{2}\right)$ & 0.0015 \\
\hline
\end{tabular}

\section{Total Emission of Pollutants.}

The total emission of pollutants corresponds to the sum of the emission from all the energy sources used in the building. The total emission of pollutants must be determined for each case, without and with the use of CHP system.

\section{Reduction of Emission of Pollutants.}

To estimate the reduction of emission of pollutants, take the total emissions from the actual energy use (case without CHP system) and subtract the emissions for the case with CHP system.

\section{RESULTS AND DISCUSSION}

This section of the paper presents results from the evaluation of CHP systems using the methodology described above for general offices. For this space type is required to know the annual energy consumption, building area, occupants, number of computers, hours of work, and geographic zone through a Zip Code. The basic information was obtained from Tables 1 and 2 (Census Region and Division) of ASHRAE [15]. The number of computers was estimated using a factor of 0.0247 computers $/ \mathrm{m}^{2}$ from the Energy Information Administration [16]. The selected cities used in this investigation are listed in Table 3. These cities were chosen to have a representation of different climates in U.S. General building information and electric and natural gas use employed for the calculations are summarized in Tables 4 and 5. The cities average temperatures and the degree-days used to estimate the energy consumption patterns are presented in Tables 6 and 7. The degree-days were obtained from an average balance point temperature of $18.3{ }^{\circ} \mathrm{C}$. 
Table 3. Cities used in this investigation

\begin{tabular}{|c|c|c|c|c|c|}
\hline $\begin{array}{l}\text { Region } \\
\text { Division }\end{array}$ & - & $\begin{array}{c}\text { Northeast - New } \\
\text { England }\end{array}$ & $\begin{array}{c}\text { Midwest - West North } \\
\text { Central }\end{array}$ & $\begin{array}{c}\text { South - West South } \\
\text { Central }\end{array}$ & $\begin{array}{l}\text { West - } \\
\text { Pacific }\end{array}$ \\
\hline City & & Boston, MA & Lincoln, NE & Austin, TX & Salem, OR \\
\hline Zip Code & & 02120 & 68510 & 78710 & 97305 \\
\hline
\end{tabular}

Table 4. General building information

\begin{tabular}{lccccc}
\hline Region & $\begin{array}{c}\text { Floor Area } \\
\text { per Bldg., } \mathrm{m}^{2}\end{array}$ & $\begin{array}{c}\text { Floor Area } \\
\text { per Person, } \\
\mathrm{ft}^{2}\end{array}$ & $\begin{array}{c}\text { Hours Worked } \\
\text { per Week }\end{array}$ & $\begin{array}{c}\text { Persons } \\
\text { per Bldg. }\end{array}$ & $\begin{array}{c}\text { Number of } \\
\text { Computers }\end{array}$ \\
\hline $\begin{array}{l}\text { Northeast, } \\
\text { Boston, MA }\end{array}$ & 1523.61 & 72.84 & 67 & 21 & 21 \\
Midwest, Lincoln, & 1133.42 & 78.41 & 59 & 15 & 16 \\
NE & 1105.55 & 73.02 & 60 & 16 & 15 \\
South, Austin, TX & 1133.42 & 60.11 & 63 & 19 & 16 \\
West, Salem, OR & 112 & & & \\
\hline
\end{tabular}

Table 5a. Electric energy use [12]

Energy End Use: Electricity, kWh/m²

\begin{tabular}{|c|c|c|c|c|c|c|c|c|c|c|}
\hline Region & $\begin{array}{c}\text { Tota } \\
1\end{array}$ & $\begin{array}{c}\text { Spac } \\
\text { e } \\
\text { Heat }\end{array}$ & $\begin{array}{c}\text { Coo } \\
1\end{array}$ & $\begin{array}{c}\text { Ventilati } \\
\text { on }\end{array}$ & $\begin{array}{l}\text { War } \\
\mathrm{e} \\
\mathrm{Hea} \\
\mathrm{t}\end{array}$ & $\begin{array}{l}\text { Lightin } \\
\mathrm{g}\end{array}$ & $\begin{array}{c}\text { Cookin } \\
\mathrm{g}\end{array}$ & $\begin{array}{l}\text { Refrigerati } \\
\text { on }\end{array}$ & $\begin{array}{l}\text { Offic } \\
\text { e } \\
\text { Equi } \\
\text { p. }\end{array}$ & $\begin{array}{c}\text { Othe } \\
r\end{array}$ \\
\hline $\begin{array}{l}\text { Northeas } \\
\text { t, } \\
\text { Boston, } \\
\text { MA }\end{array}$ & $\begin{array}{c}101 . \\
3\end{array}$ & 2.5 & 9.8 & 5.0 & 3.2 & 51.7 & 0.9 & 6.0 & 13.2 & 8.8 \\
\hline $\begin{array}{l}\text { Midwest } \\
\text { Lincoln, } \\
\text { NE }\end{array}$ & $\begin{array}{c}142 . \\
6\end{array}$ & 5.7 & $\begin{array}{c}14 . \\
2\end{array}$ & 9.8 & 2.2 & 71.9 & 0.6 & 6.9 & 20.2 & 11.0 \\
\hline $\begin{array}{l}\text { South, } \\
\text { Austin, } \\
\text { TX }\end{array}$ & $\begin{array}{c}153 . \\
9\end{array}$ & 3.8 & $\begin{array}{c}28 . \\
4\end{array}$ & 10.7 & 2.2 & 65.9 & 0.9 & 12.6 & 17.0 & 12.3 \\
\hline $\begin{array}{l}\text { West, } \\
\text { Salem, } \\
\text { OR }\end{array}$ & $\begin{array}{c}164 . \\
7\end{array}$ & 8.2 & $\begin{array}{c}17 . \\
0\end{array}$ & 9.8 & 2.2 & 78.5 & 1.3 & 11.4 & 24.0 & 12.3 \\
\hline
\end{tabular}

Table 5b. Natural gas energy use [12]

\begin{tabular}{lccccc}
\hline \multirow{2}{*}{ Region } & \multicolumn{5}{c}{ Natural Gas, $\mathrm{kWh} / \mathrm{m}^{2}-\mathrm{yr}$} \\
\cline { 2 - 6 } & Total & Space Heat & Water Heat & Cooking & Other \\
\hline $\begin{array}{l}\text { Northeast, } \\
\text { Boston, MA } \\
\text { Midwest, }\end{array}$ & 161.8 & 90.5 & 46.7 & 11.0 & 13.6 \\
\hline
\end{tabular}




\begin{tabular}{lccccc}
\hline Lincoln, NE & & & & & \\
South, & 122.1 & 53.0 & 41.6 & 19.9 & 7.6 \\
$\begin{array}{l}\text { Austin, TX } \\
\begin{array}{l}\text { West, } \\
\text { Salem, OR }\end{array}\end{array}$ & 133.8 & 40.7 & 56.2 & 22.4 & 14.5 \\
\hline
\end{tabular}

Table 6. Average temperatures in ${ }^{\circ} \mathrm{C}$

\begin{tabular}{lcccc}
\hline Month & $\begin{array}{c}\text { Boston, } \\
\text { MA }\end{array}$ & $\begin{array}{c}\text { Lincoln, } \\
\text { NE }\end{array}$ & Austin, TX & Salem, OR \\
\hline January & -1.4 & -5.6 & 9.7 & 4.2 \\
February & -0.3 & -2.8 & 11.9 & 5.8 \\
March & 3.9 & 3.6 & 16.1 & 7.5 \\
April & 9.2 & 10.8 & 20.3 & 9.7 \\
May & 14.7 & 16.7 & 23.9 & 13.1 \\
June & 20.0 & 22.5 & 27.5 & 16.1 \\
July & 23.3 & 25.3 & 29.2 & 19.2 \\
August & 22.5 & 23.9 & 29.4 & 19.2 \\
September & 18.3 & 18.6 & 26.4 & 16.7 \\
October & 12.2 & 11.7 & 21.1 & 11.4 \\
November & 7.2 & 3.3 & 15.3 & 7.2 \\
December & 1.7 & -3.3 & 11.4 & 4.7 \\
Year & 10.9 & 10.4 & 20.2 & 11.2 \\
\hline
\end{tabular}

Table 7. Monthly cooling-degree days and heating degree-days for space and water

\begin{tabular}{|c|c|c|c|c|c|c|c|c|c|c|c|c|}
\hline \multirow[t]{3}{*}{ Month } & \multicolumn{3}{|c|}{ Boston, MA } & \multicolumn{3}{|c|}{ Lincoln, NE } & \multicolumn{3}{|c|}{ Austin, TX } & \multicolumn{3}{|c|}{ Salem, OR } \\
\hline & $\mathrm{D}$ & (DD & (DDh & $\mathrm{DD}$ & (DD & (DDh & $\mathrm{DD}$ & (DD & $(\mathrm{DDh}$ & D & (DD & $(\mathrm{DDh}$ \\
\hline & Dc & h)s & )w & $\mathrm{c}$ & h)s & ) $\mathrm{w}$ & $\mathrm{c}$ & h)s & )w & Dc & h)s & )w \\
\hline $\begin{array}{l}\text { January } \\
\text { Februar }\end{array}$ & 0 & 1101 & 1101 & 0 & 1333 & 1333 & 0 & 486 & 486 & 0 & 791 & 791 \\
\hline $\mathrm{y}$ & 0 & 938 & 938 & 0 & 1064 & 1064 & 0 & 331 & 331 & 0 & 631 & 631 \\
\hline March & 0 & 808 & 808 & 0 & 824 & 824 & 0 & 167 & 167 & 0 & 607 & 607 \\
\hline April & 0 & 501 & 501 & 0 & 417 & 417 & 144 & 0 & 39 & 0 & 469 & 469 \\
\hline May & $\begin{array}{c}0 \\
14\end{array}$ & 234 & 234 & 0 & 160 & 160 & 317 & 0 & 7 & 0 & 307 & 307 \\
\hline June & $\begin{array}{c}0 \\
29\end{array}$ & 0 & 50 & 247 & 0 & 22 & 496 & 0 & 1 & $\begin{array}{c}0 \\
10\end{array}$ & 155 & 155 \\
\hline July & $\begin{array}{c}1 \\
25\end{array}$ & 0 & 12 & 394 & 0 & 7 & 605 & 0 & 0 & $\begin{array}{c}5 \\
10\end{array}$ & 0 & 58 \\
\hline $\begin{array}{l}\text { August } \\
\text { Septem }\end{array}$ & 1 & 0 & 18 & 323 & 0 & 13 & 620 & 0 & 0 & 5 & 0 & 58 \\
\hline ber & 0 & 0 & 90 & 106 & 0 & 91 & 436 & 0 & 1 & 0 & 133 & 133 \\
\hline October & 0 & 356 & 356 & 0 & 389 & 389 & 183 & 0 & 28 & 0 & 395 & 395 \\
\hline & 0 & 603 & 603 & 0 & 812 & 812 & 0 & 196 & 196 & 0 & 602 & 602 \\
\hline
\end{tabular}




\begin{tabular}{lcccccccccccc}
\hline $\begin{array}{l}\text { Decem } \\
\text { ber }\end{array}$ & 0 & 931 & 931 & 0 & 1210 & 1210 & 0 & 397 & 397 & 0 & 761 & 761 \\
Total & 68 & & & 106 & & & 280 & & & 20 & & \\
& 1 & 5473 & 5642 & 9 & 6210 & 6341 & 0 & 1577 & 1653 & 9 & 4851 & 4968 \\
\hline
\end{tabular}

Using the methodology to estimate the energy consumption described in the previous section, the energy consumption patterns, on a monthly basis, were calculated to be used in the Target Finder tool. For all the calculations presented in this section, the PGU electric efficiency and the boiler thermal efficiency were kept constant at $30 \%$ and $90 \%$, respectively. To account for the PGU size on the overall performance, the fraction of the annual total electric energy use, $f_{e}$, were changed from 0 to 1 in steps of 0.1 . Also, typical coefficients of performance values of $3.8\left(0.92 \mathrm{~kW}_{\mathrm{e}} /\right.$ Ton $)$ for the vapor compression system and $0.8\left(4.4 \mathrm{~kW}_{\mathrm{h}} /\right.$ Ton $)$ for the absorption chiller were considered. The monthly energy consumption patterns per unit area obtained with this methodology for the cities of Boston, Lincoln, Austin, and Salem, are presented in Table 8.

Table 8. Estimated monthly energy consumption patterns $\left(1000 \mathrm{kWh} / \mathrm{m}^{2}\right)$

\begin{tabular}{|c|c|c|c|c|c|c|c|c|c|c|c|c|}
\hline \multirow[b]{2}{*}{ Month } & \multicolumn{6}{|c|}{ Boston, MA } & \multicolumn{6}{|c|}{ Lincoln, NE } \\
\hline & $\begin{array}{c}\text { Spac } \\
\text { e } \\
\text { Cooli } \\
\text { ng } \\
\end{array}$ & $\begin{array}{c}\text { Spac } \\
\text { e } \\
\text { Heati } \\
\text { ng } \\
\end{array}$ & $\begin{array}{c}\text { Wate } \\
\text { r } \\
\text { Heati } \\
\text { ng } \\
\end{array}$ & $\begin{array}{c}\text { Total } \\
\text { Heati } \\
\text { ng }\end{array}$ & $\begin{array}{c}\text { Tot } \\
\text { al } \\
\text { Ele } \\
\text { ct. }\end{array}$ & $\begin{array}{c}\text { Tot } \\
\text { al } \\
\text { N.G }\end{array}$ & $\begin{array}{c}\text { Spac } \\
\text { e } \\
\text { Cooli } \\
\text { ng } \\
\end{array}$ & $\begin{array}{c}\text { Spac } \\
\text { e } \\
\text { Heati } \\
\text { ng }\end{array}$ & $\begin{array}{c}\text { Wate } \\
\text { r } \\
\text { Heati } \\
\text { ng }\end{array}$ & $\begin{array}{c}\text { Total } \\
\text { Heati } \\
\text { ng }\end{array}$ & $\begin{array}{l}\text { Tot } \\
\text { al } \\
\text { Ele } \\
\text { ct. }\end{array}$ & $\begin{array}{c}\text { Tot } \\
\text { al } \\
\text { N.G }\end{array}$ \\
\hline Januar & & & & & & 29. & & & & & 10. & 46. \\
\hline $\begin{array}{l}\text { y } \\
\text { Februa }\end{array}$ & 0.0 & 18.2 & 9.1 & 27.3 & 7.6 & $\begin{array}{c}4 \\
25 .\end{array}$ & 0.0 & 36.2 & 8.9 & 45.0 & $\begin{array}{c}7 \\
10 .\end{array}$ & $\begin{array}{c}7 \\
37 .\end{array}$ \\
\hline ry & 0.0 & 15.5 & 7.8 & 23.3 & 7.6 & $\begin{array}{c}3 \\
22 .\end{array}$ & 0.0 & 28.9 & 7.1 & 36.0 & $\begin{array}{c}7 \\
10 .\end{array}$ & $\begin{array}{c}6 \\
29 .\end{array}$ \\
\hline March & 0.0 & 13.4 & 6.7 & 20.0 & 7.6 & $\begin{array}{c}1 \\
14 .\end{array}$ & 0.0 & 22.4 & 5.5 & 27.9 & $\begin{array}{c}7 \\
10 .\end{array}$ & $\begin{array}{c}4 \\
15 .\end{array}$ \\
\hline April & 0.0 & 8.3 & 4.1 & 12.4 & 7.6 & 5 & 0.0 & 11.3 & 2.8 & 14.1 & $\begin{array}{c}7 \\
10 .\end{array}$ & 7 \\
\hline May & 0.0 & 3.9 & 1.9 & 5.8 & 7.6 & 7.9 & 0.0 & 4.3 & 1.1 & 5.4 & $\begin{array}{c}7 \\
14 .\end{array}$ & 7.0 \\
\hline June & 2.0 & 0.0 & 0.4 & 0.4 & $\begin{array}{l}9.6 \\
11 .\end{array}$ & 2.5 & 3.3 & 0.0 & 0.2 & 0.2 & $\begin{array}{c}0 \\
15 .\end{array}$ & 1.7 \\
\hline July & 4.2 & 0.0 & 0.1 & 0.1 & $\begin{array}{c}8 \\
11 .\end{array}$ & 2.1 & 5.2 & 0.0 & 0.0 & 0.0 & $\begin{array}{c}9 \\
15 .\end{array}$ & 1.6 \\
\hline $\begin{array}{l}\text { August } \\
\text { Septem }\end{array}$ & 3.6 & 0.0 & 0.2 & 0.2 & 2 & 2.2 & 4.3 & 0.0 & 0.1 & 0.1 & $\begin{array}{c}0 \\
12 .\end{array}$ & 1.7 \\
\hline $\begin{array}{l}\text { ber } \\
\text { Octobe }\end{array}$ & 0.0 & 0.0 & 0.8 & 0.8 & 7.6 & $\begin{array}{l}2.8 \\
10 .\end{array}$ & 1.4 & 0.0 & 0.6 & 0.6 & $\begin{array}{c}1 \\
10 .\end{array}$ & $\begin{array}{l}2.2 \\
14 .\end{array}$ \\
\hline $\begin{array}{l}\mathrm{r} \\
\text { Novem }\end{array}$ & 0.0 & 5.9 & 2.9 & 8.8 & 7.6 & 9 & 0.0 & 10.6 & 2.6 & 13.2 & 7 & 8 \\
\hline $\begin{array}{l}\text { Novem } \\
\text { ber } \\
\text { Decem }\end{array}$ & 0.0 & 10.0 & 5.0 & 15.0 & 7.6 & $\begin{array}{c}17 . \\
0 \\
25 .\end{array}$ & 0.0 & 22.0 & 5.4 & 27.4 & $\begin{array}{c}10 . \\
7 \\
10 .\end{array}$ & $\begin{array}{c}29 . \\
1 \\
42 .\end{array}$ \\
\hline ber & 0.0 & 15.4 & 7.7 & 23.1 & 7.6 & 1 & 0.0 & 32.8 & 8.1 & 40.9 & 7 & 5 \\
\hline Year & 9.8 & 90.5 & 46.7 & 137.2 & 101 & 161 & 14.2 & 168.5 & 42.3 & 210.7 & 142 & 230 \\
\hline
\end{tabular}




\begin{tabular}{|c|c|c|c|c|c|c|c|c|c|c|c|c|}
\hline & & & & & .3 & .8 & & & & & .6 & .0 \\
\hline & & & Austin & TX & & & & & Salem, & OR & & \\
\hline Month & $\begin{array}{c}\text { Spac } \\
\text { e } \\
\text { Cooli } \\
\text { ng } \\
\end{array}$ & $\begin{array}{c}\text { Spac } \\
\text { e } \\
\text { Heati } \\
\text { ng } \\
\end{array}$ & $\begin{array}{c}\text { Wate } \\
\text { r } \\
\text { Heati } \\
\text { ng } \\
\end{array}$ & $\begin{array}{c}\text { Total } \\
\text { Heati } \\
\text { ng }\end{array}$ & $\begin{array}{l}\text { Tot } \\
\text { al } \\
\text { Ele } \\
\text { ct. }\end{array}$ & $\begin{array}{l}\text { Tot } \\
\text { al } \\
\text { N.G }\end{array}$ & $\begin{array}{c}\text { Spac } \\
\mathrm{e} \\
\text { Cooli } \\
\text { ng } \\
\end{array}$ & $\begin{array}{c}\text { Spac } \\
\text { e } \\
\text { Heati } \\
\text { ng }\end{array}$ & $\begin{array}{c}\text { Wate } \\
\text { r } \\
\text { Heati } \\
\text { ng } \\
\end{array}$ & $\begin{array}{c}\text { Total } \\
\text { Heati } \\
\text { ng }\end{array}$ & $\begin{array}{c}\text { Tot } \\
\text { al } \\
\text { Ele } \\
\text { ct. }\end{array}$ & $\begin{array}{c}\text { Tot } \\
\text { al } \\
\text { N.G }\end{array}$ \\
\hline Januar & & & & & 10. & 30. & & & & & 12. & 18. \\
\hline $\begin{array}{l}\text { y } \\
\text { Februa }\end{array}$ & 0.0 & 16.3 & 12.2 & 28.6 & $\begin{array}{c}5 \\
10 .\end{array}$ & $\begin{array}{c}9 \\
21 .\end{array}$ & 0.0 & 6.6 & 9.0 & 15.6 & $\begin{array}{c}3 \\
12 .\end{array}$ & $\begin{array}{c}7 \\
15 .\end{array}$ \\
\hline ry & 0.0 & 11.1 & 8.3 & 19.4 & $\begin{array}{c}5 \\
10 .\end{array}$ & $\begin{array}{c}7 \\
12 .\end{array}$ & 0.0 & 5.3 & 7.1 & 12.4 & $\begin{array}{c}3 \\
12 .\end{array}$ & $\begin{array}{c}5 \\
15 .\end{array}$ \\
\hline March & 0.0 & 5.6 & 4.2 & 9.8 & $\begin{array}{c}5 \\
11 .\end{array}$ & 1 & 0.0 & 5.1 & 6.8 & 12.0 & $\begin{array}{c}3 \\
12 .\end{array}$ & $\begin{array}{c}0 \\
12 .\end{array}$ \\
\hline April & 1.5 & 0.0 & 1.0 & 1.0 & $\begin{array}{c}9 \\
13 .\end{array}$ & 3.2 & 0.0 & 3.9 & 5.3 & 9.2 & $\begin{array}{c}3 \\
12 .\end{array}$ & 3 \\
\hline May & 3.2 & 0.0 & 0.2 & 0.2 & $\begin{array}{c}7 \\
15 .\end{array}$ & 2.5 & 0.0 & 2.6 & 3.5 & 6.1 & $\begin{array}{c}3 \\
12 .\end{array}$ & 9.1 \\
\hline June & 5.0 & 0.0 & 0.0 & 0.0 & $\begin{array}{c}5 \\
16 .\end{array}$ & 2.3 & 0.0 & 1.3 & 1.8 & 3.1 & $\begin{array}{c}3 \\
20 .\end{array}$ & 6.2 \\
\hline July & 6.1 & 0.0 & 0.0 & 0.0 & $\begin{array}{c}6 \\
16 .\end{array}$ & 2.3 & 8.5 & 0.0 & 0.7 & 0.7 & $\begin{array}{c}8 \\
20 .\end{array}$ & 3.7 \\
\hline $\begin{array}{l}\text { August } \\
\text { Septem }\end{array}$ & 6.3 & 0.0 & 0.0 & 0.0 & $\begin{array}{c}8 \\
14 .\end{array}$ & 2.3 & 8.5 & 0.0 & 0.7 & 0.7 & $\begin{array}{c}8 \\
12 .\end{array}$ & 3.7 \\
\hline $\begin{array}{l}\text { ber } \\
\text { Octobe }\end{array}$ & 4.4 & 0.0 & 0.0 & 0.0 & $\begin{array}{c}9 \\
12 .\end{array}$ & 2.3 & 0.0 & 1.1 & 1.5 & 2.6 & $\begin{array}{c}3 \\
12 .\end{array}$ & $\begin{array}{l}5.7 \\
10 .\end{array}$ \\
\hline $\begin{array}{l}\mathrm{r} \\
\text { Novem }\end{array}$ & 1.9 & 0.0 & 0.7 & 0.7 & $\begin{array}{c}3 \\
10 .\end{array}$ & $\begin{array}{l}3.0 \\
13 .\end{array}$ & 0.0 & 3.3 & 4.4 & 7.8 & $\begin{array}{c}3 \\
12 .\end{array}$ & $\begin{array}{c}9 \\
14 .\end{array}$ \\
\hline $\begin{array}{l}\text { ber } \\
\text { Decem }\end{array}$ & 0.0 & 6.6 & 4.9 & 11.5 & $\begin{array}{c}5 \\
10 .\end{array}$ & $\begin{array}{c}8 \\
25 .\end{array}$ & 0.0 & 5.0 & 6.8 & 11.9 & $\begin{array}{c}3 \\
12 .\end{array}$ & $\begin{array}{c}9 \\
18 .\end{array}$ \\
\hline ber & 0.0 & 13.3 & 10.0 & 23.3 & $\begin{array}{c}5 \\
153\end{array}$ & $\begin{array}{c}6 \\
122\end{array}$ & 0.0 & 6.4 & 8.6 & 15.0 & $\begin{array}{c}3 \\
164\end{array}$ & $\begin{array}{c}0 \\
133\end{array}$ \\
\hline Year & 28.4 & 53.0 & 41.6 & 94.6 & .9 & .1 & 17.0 & 40.7 & 56.2 & 96.8 & .7 & .8 \\
\hline
\end{tabular}

The values used in Target Finder to find the Energy Star rating correspond to the total or annual electricity and natural gas for the data presented in Table 8. Figure 2 shows the variation of the Energy Star rating with the fraction of the annual electric energy use based on the results given by Target Finder for the cities evaluated in this paper. From this figure it can be seen that for all the evaluated cities, CHP system gives a higher rating than the reference condition $\left(f_{e}=0\right)$. Also it can be observed that there is a fraction of the total energy handled by the PGU, $f_{\mathrm{e}}$, that gives the highest rating. For all the evaluated cities, the fraction that produces the maximum rating is not the same. With the methodology used the $f_{\mathrm{e}}$ that gives the highest rating are in a range of 0.8 to 1.0. These high values of $f_{\mathrm{e}}$ can be explained because the methodology considers that the total electric energy could be handled by the PGU. However, if hourly energy use patterns are considered, there are fractions of the day when the electric energy use is too low to justify the PGU operation. As a result, the $f_{\mathrm{e}}$ range that gives the highest rating might be reduced. 


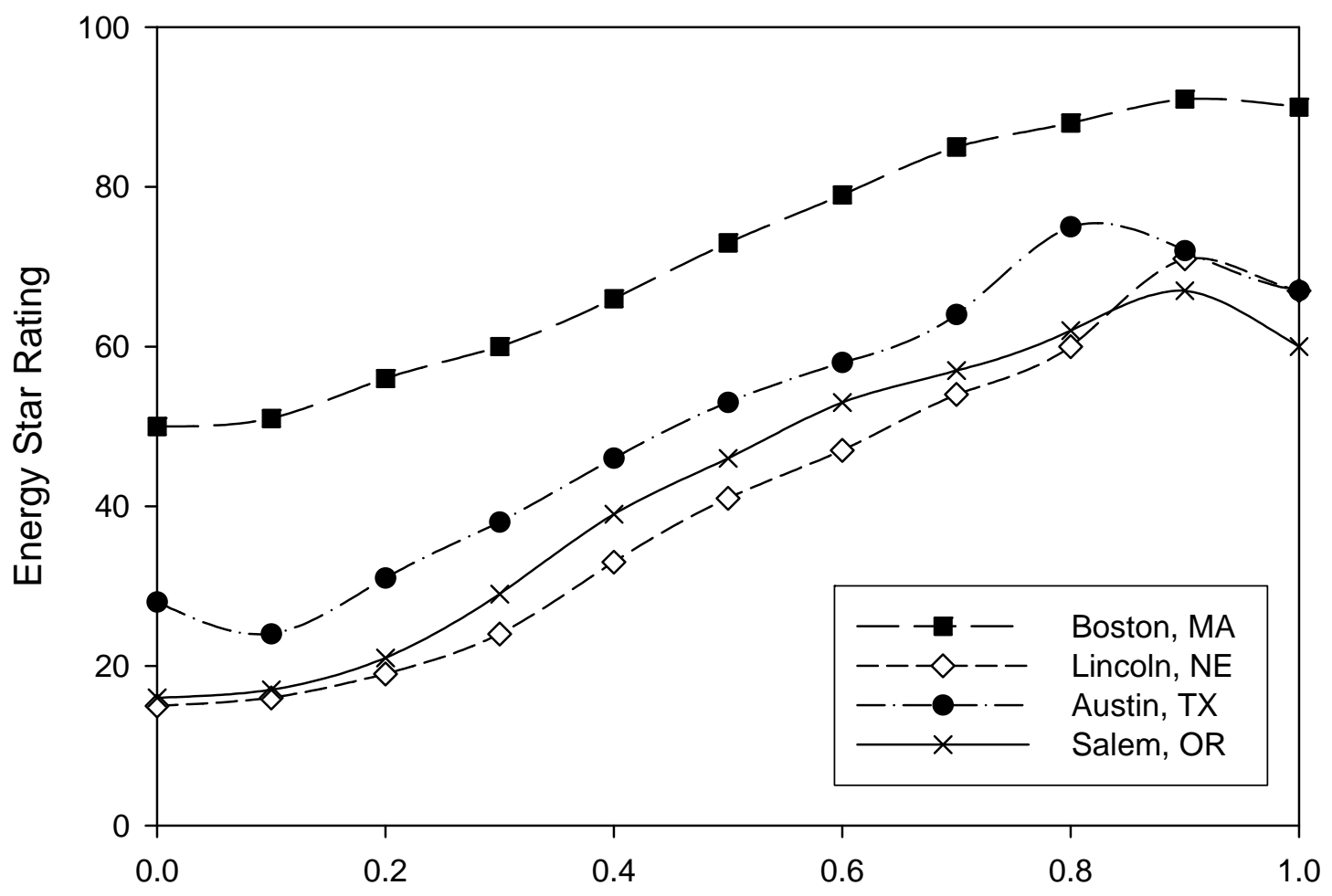

Fraction of the Annual Electric Energy Use

Figure 2. Comparison of the Energy Star rating from the use of CHP for the cities of Boston, Lincoln, Austin, and Salem

Figure 3 shows the comparison of the maximum Energy Star rating for CHP Systems with respect to the reference energy consumption (original values). Figure 3 illustrates that independently of the rating obtained with the reference energy consumption, the use of CHP systems always increases the rating. The main factors giving more or less increase in the rating are the energy use patterns and the fuel mix for the grid region. In this investigation, energy use patters represent the proportion among the amount of electric energy for uses other than cooling, the electric energy use for cooling, and the fuel energy for heating. Since the rating considers source energy (primary energy) the analysis of two buildings with the same initial rating, but with different energy use patterns, will give different increment of the rating. Also, the use of CHP systems in a region with more fossil fuels in the fuel mix will improve the rating more than for a region with more renewable sources in the fuel mix. For CHP systems, the least incremental increase was 41 points for the city of Boston, while the greatest incremental increase was 56 for the cities of Lincoln and Phoenix. From this figure it can be observed that for the 
cities of Boston and Austin the use of CHP systems can raise the Energy Star rating of a building above a rating of 75 points, which meet the first step for an Energy Star certification.

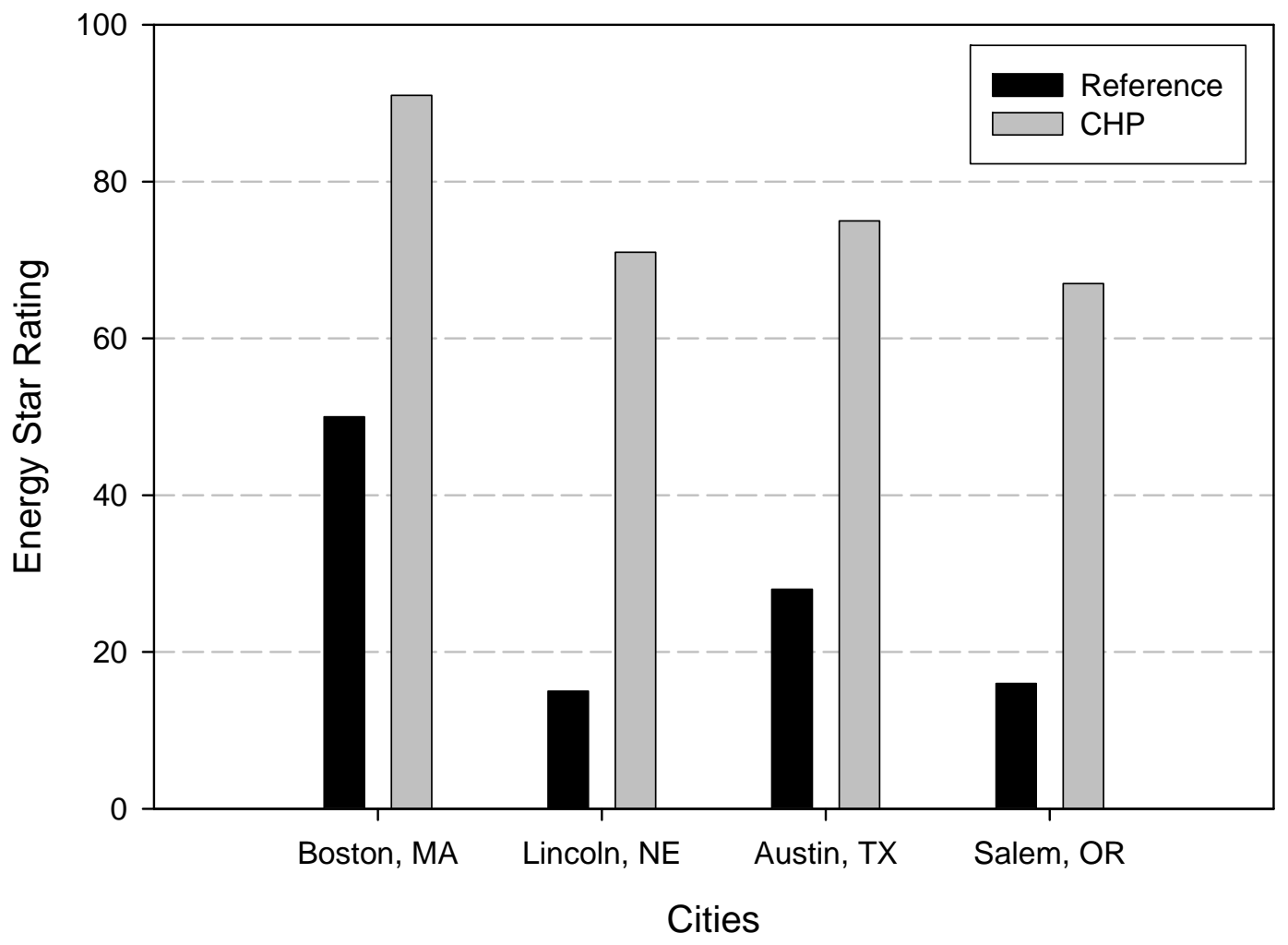

Figure 3. Comparison of the maximum Energy Star rating for CHP

With respect to the LEED Green Building Rating, (from Table 1), for Credit 1 - Optimize Energy Performance - Boston is the city that can obtained the maximum points (8) from the use of CHP systems. Austin, Lincoln, and Salem can obtain 4 points, 3 points, and 1 point, respectively. It is also possible that for some cities, the Energy Star rating does not reach sufficiently high values to get points for the LEED Rating because the initial Energy Star rating is too low. On the other hand, since CHP systems reduce the energy source consumption, emissions will also be reduced and points from Credit 5.4 - Performance Measurement: Emission Reduction Reporting - could be obtained.

Results illustrates that for each building the Target Finder must be run since the rating depends on the patterns of energy use (cooling, heating, total electricity, and total natural gas), characteristics of the building, and the benchmark for which the building is being compared. Then, in order to determine the benefits on energy rating from the use of CHP systems, the methodology presented in this section must be applied for any particular case.

To estimate emission of pollutants from the use of distributed generation (DG) systems, the energy consumption is used to estimate the amount of pollutants by using emission factors. Similarly as before, the energy consumption is related to the use of electricity and natural gas from utilities (site energy). The overall result represents the sum of pollutants from the use of 
electricity (grid) and natural gas (NG). The total energy consumption patterns to estimate the emission of pollutants are presented in Table 9. The total energy consumption were obtained by multiplying the monthly energy consumption patterns of Table 8 by the average building area on Table 4 and the use of appropriate units for the calculation of pollutants according with the methodology described in this paper.

As stated in the definition of the emission factor for electricity, the amount of pollutants depends on the fuel mix used to generate electricity in the region where the energy has been used. To better understand the results, Figure 4 shows the fuel mix comparison for the grid region of Salem, OR; Lincoln, NE; Austin, TX; and Boston, MA, obtained from Power Profiler. For the grid regions of Salem and Boston, $63 \%$ and $45 \%$ of the electric power comes from sources other than fossil fuels, respectively, while for the regions of Lincoln and Austin, only $22 \%$ and $12 \%$ of the electric power comes from sources other than fossil fuels, respectively. Then, for the same energy consumption among the evaluated cities, more pollutants will be generated in the cities of Lincoln and Austin than in the cities of Salem and Boston. On the other hand, coal is a fuel with a significant weight on the fuel mix for all the grid regions, and the one responsible for the major part of the emission of nitrogen oxides $\left(\mathrm{NO}_{\mathrm{x}}\right)$ and sulfur dioxide $\left(\mathrm{SO}_{2}\right)$. In this study, the reduction of electric energy from the grid is substituted for energy from natural gas used by the CHP system.

Table 9. Energy consumption patterns used to estimate emission of pollutants*

\begin{tabular}{ccccccccc}
\hline & \multicolumn{2}{c}{ Boston, MA } & \multicolumn{2}{c}{ Lincoln, NE } & \multicolumn{2}{c}{ Austin, TX } & \multicolumn{2}{c}{ Salem, OR } \\
\cline { 2 - 8 }$f_{\mathrm{e}}$ & $\begin{array}{c}\mathrm{Grid} \\
\mathrm{kWh} / \mathrm{yr}\end{array}$ & $\begin{array}{c}\mathrm{NG} \\
\mathrm{kWh} / \mathrm{yr}\end{array}$ & $\begin{array}{c}\text { Grid } \\
\mathrm{kWh} / \mathrm{yr}\end{array}$ & $\begin{array}{c}\mathrm{NG} \\
\mathrm{kWh} / \mathrm{yr}\end{array}$ & $\begin{array}{c}\text { Grid } \\
\mathrm{kWh} / \mathrm{yr}\end{array}$ & $\begin{array}{c}\mathrm{NG} \\
\mathrm{kWh} / \mathrm{yr}\end{array}$ & $\begin{array}{c}\text { Grid } \\
\mathrm{kWh} / \mathrm{yr}\end{array}$ & $\begin{array}{c}\text { NG } \\
\mathrm{kWh} / \mathrm{yr}\end{array}$ \\
\hline 0.0 & 154,291 & 252,627 & 161,618 & 266,988 & 170,199 & 138,330 & 186,401 & 155,035 \\
0.1 & 123,961 & 332,929 & 129,366 & 354,616 & 121,790 & 308,604 & 148,603 & 254,972 \\
0.2 & 108,532 & 341,428 & 113,204 & 363,701 & 104,770 & 325,016 & 129,866 & 264,057 \\
0.3 & 93,103 & 350,220 & 97,042 & 373,079 & 87,750 & 341,721 & 111,130 & 275,194 \\
0.4 & 77,674 & 358,719 & 80,880 & 376,010 & 70,730 & 349,341 & 92,394 & 289,847 \\
0.5 & 62,245 & 368,976 & 64,719 & 387,147 & 53,710 & 355,788 & 73,658 & 307,725 \\
0.6 & 46,816 & 379,820 & 48,557 & 398,577 & 36,691 & 376,010 & 54,921 & 331,170 \\
0.7 & 31,387 & 376,596 & 32,395 & 410,299 & 19,671 & 397,404 & 36,185 & 358,133 \\
0.8 & 15,958 & 389,198 & 16,233 & 425,539 & 2,651 & 401,214 & 17,449 & 389,491 \\
0.9 & 529 & 402,093 & 72 & 422,901 & 0 & 422,315 & 0 & 420,850 \\
1.0 & 0 & 417,040 & 0 & 438,727 & 0 & 445,468 & 0 & 452,209 \\
1.1 & 0 & 432,280 & 0 & 430,521 & 0 & 445,175 & 0 & 483,567 \\
1.2 & 0 & 449,571 & 0 & 446,347 & 0 & 443,709 & 0 & 514,926 \\
\hline
\end{tabular}

* To estimate the energy consumption the building areas considered per region were: for Northeast $1524 \mathrm{~m}^{2}$, for Midwest $1133 \mathrm{~m}^{2}$, for South $1106 \mathrm{~m}^{2}$ and for the West $1133 \mathrm{~m}^{2}$. 


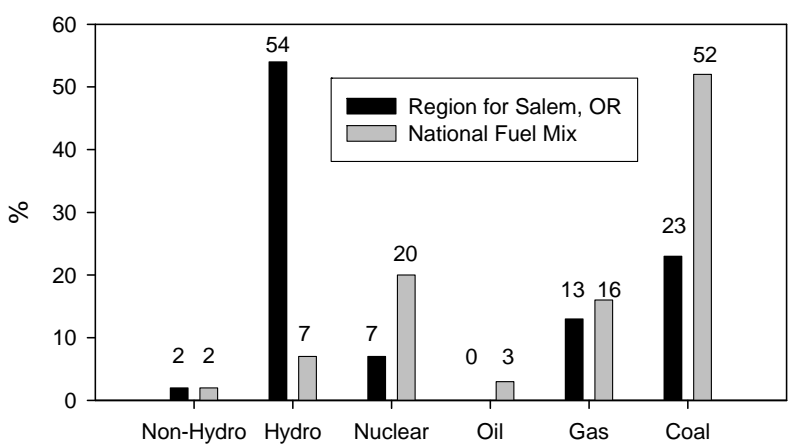

(a)

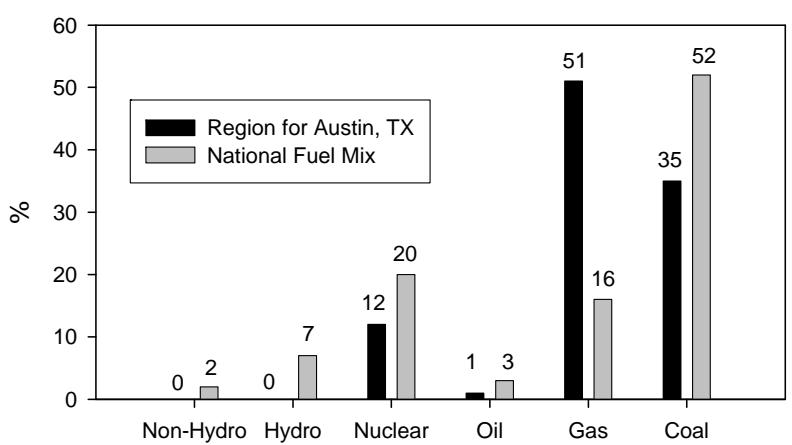

(c)

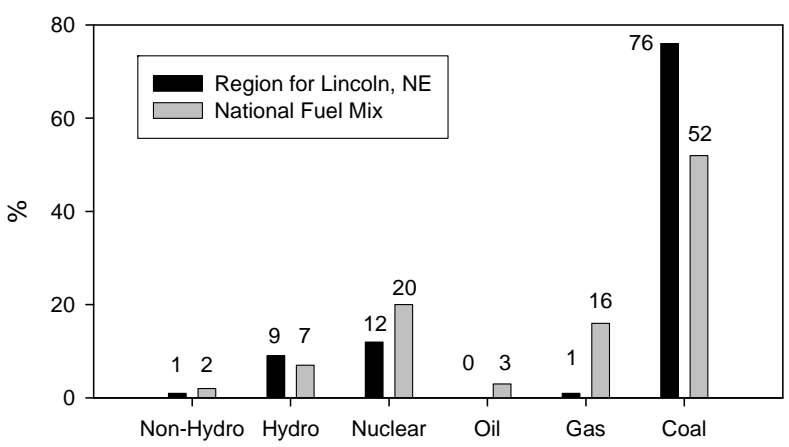

(b)

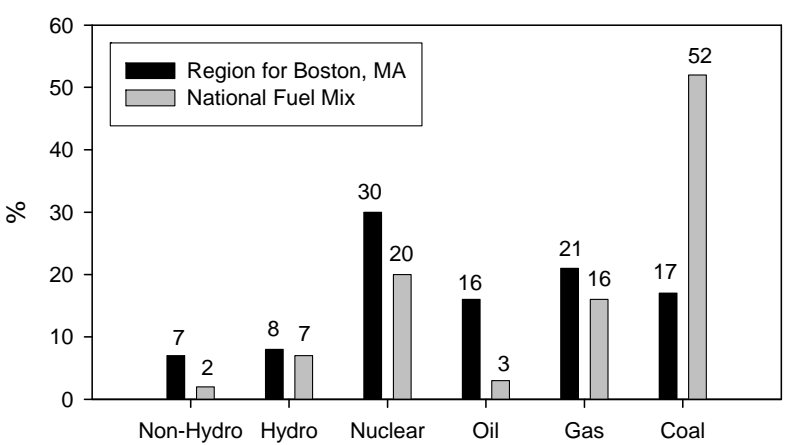

(d)

Figure 4. Fuel mix comparison for the grid region of: (a) Salem, OR, (a) Lincoln, NE, (c) Austin, TX, and (d) Boston, MA

For CHP systems, Figures 5, 6, and 7 show the estimated emission of carbon dioxide $\left(\mathrm{CO}_{2}\right)$, nitrogen oxides $\left(\mathrm{NO}_{\mathrm{x}}\right)$, and sulfur dioxide $\left(\mathrm{SO}_{2}\right)$, respectively, while Figures 8 , 9, and 10 present the percentage of reduction for $\mathrm{CO}_{2}, \mathrm{NO}_{\mathrm{x}}$, and $\mathrm{SO}_{2}$, respectively. For all figures, the results are presented as a function of the fraction of the annual electric energy use that will be provided by the PGU of the CHP system. The base line of Figures 5 through Figure 10 is the fraction of the annual electric energy use equal to zero. For all three pollutants, the higher reduction occurs for a fraction of the annual electric energy use in the range of 0.8 to 1 . These results agree with the Energy Start rating results presented before.

For all the cities considered, CHP systems reduce the emission of $\mathrm{CO}_{2}$. Figure 5 shows that for the grid region of Salem (OR), where the electric power generation from fossil fuels is only $36 \%$, CHP systems are still able to reduce the emission of $\mathrm{CO}_{2}$. Figure 8 illustrates that as much as $60 \%$ in emission reduction can be obtained from CHP systems. The maximum reduction was obtained for Lincoln while the lowest reduction was obtained for Salem.

For all the analyzed cases, CHP systems also reduce the emission of $\mathrm{NO}_{\mathrm{x}}$. In general CHP has a great impact on the $\mathrm{NO}_{\mathrm{x}}$ reduction because CHP reduces the electric energy consumption from the grid while switching to the consumption of natural gas. Figure 9 shows that the lowest percentage of reduction is $56 \%$ for Salem, and the highest reduction is $82 \%$ for Lincoln.

Finally, the use of CHP systems reduces the emission of $\mathrm{SO}_{2}$ for all the evaluated cities. In general, CHP systems have the ability to reduce by more than $90 \%$ the emission of $\mathrm{SO}_{2}$. As can be seen from Figures 7 and 10, CHP systems reduce to almost zero the emission of $\mathrm{SO}_{2}$ for all the cities considered. This can be explained because when the electric energy required for a 
building is supplied by the power generation unit of the CHP system, the incoming energy comes from natural gas which has an emission factor for $\mathrm{SO}_{2}$ of $0.0015 \mathrm{~kg} / \mathrm{MWh}(0.001 \mathrm{lb} / \mathrm{MBtu})$.

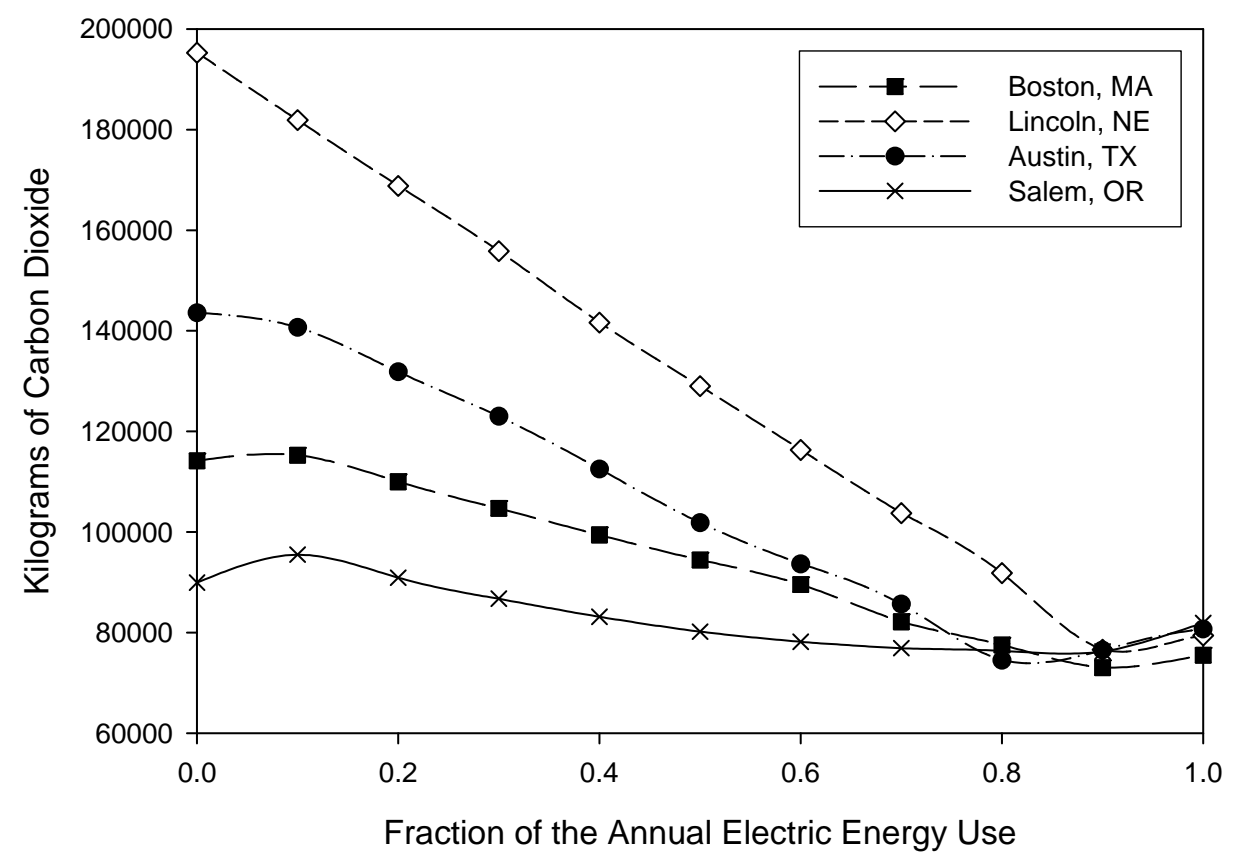

Figure 5. Emission of carbon dioxide $\left(\mathrm{CO}_{2}\right)$

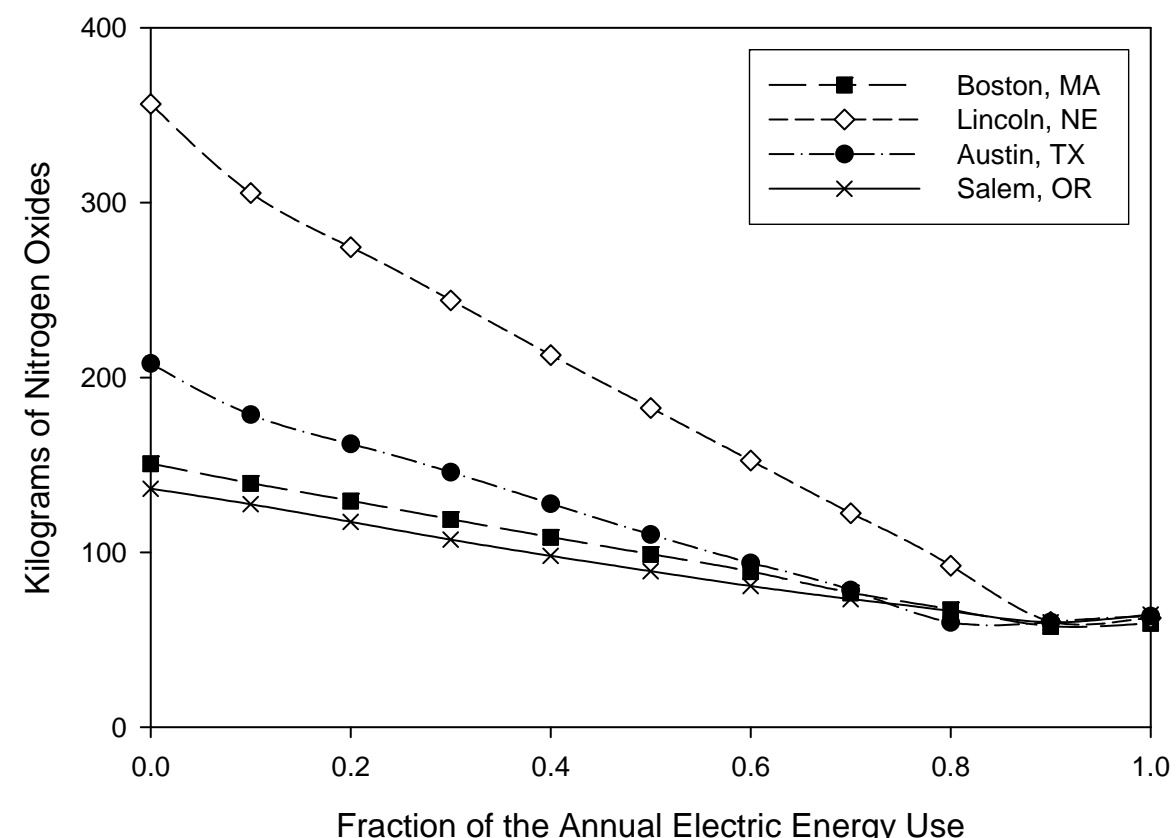

Figure 6. Emission of nitrogen oxides $\left(\mathrm{NO}_{\mathrm{x}}\right)$ 


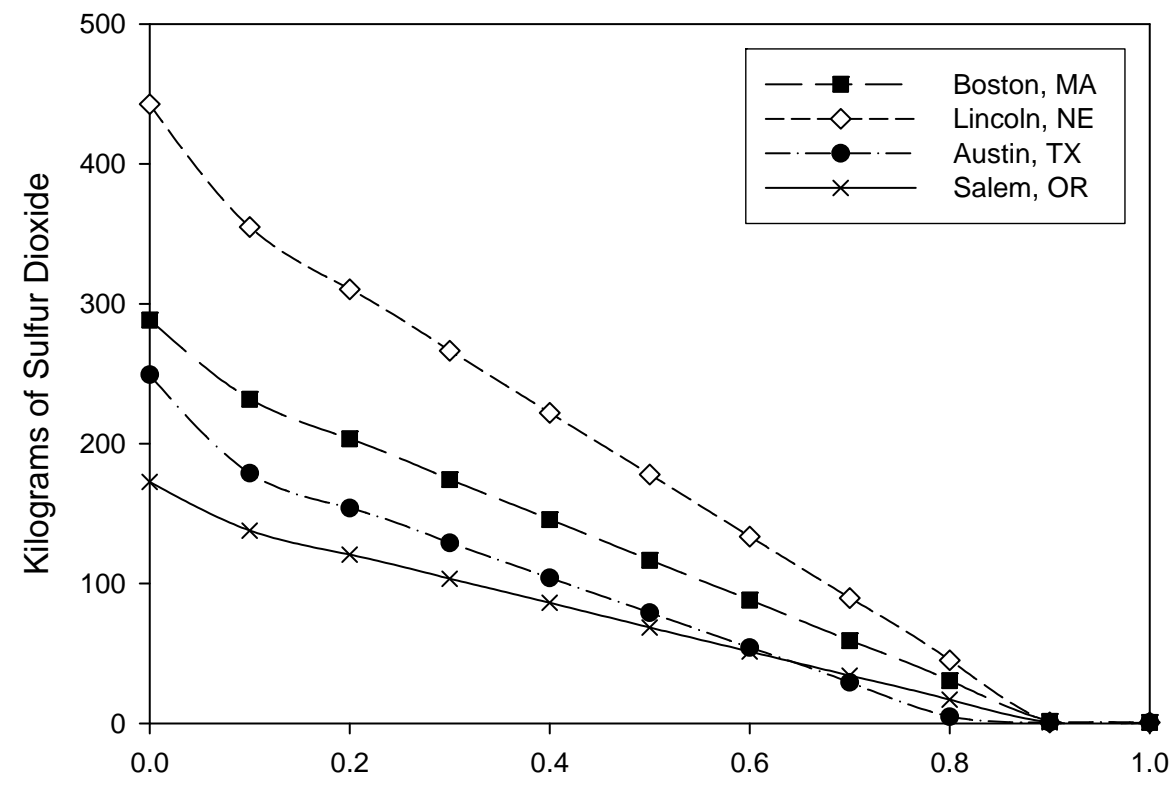

Fraction of the Annual Electric Energy Use Figure 7. Emission of sulfur dioxide $\left(\mathrm{SO}_{2}\right)$

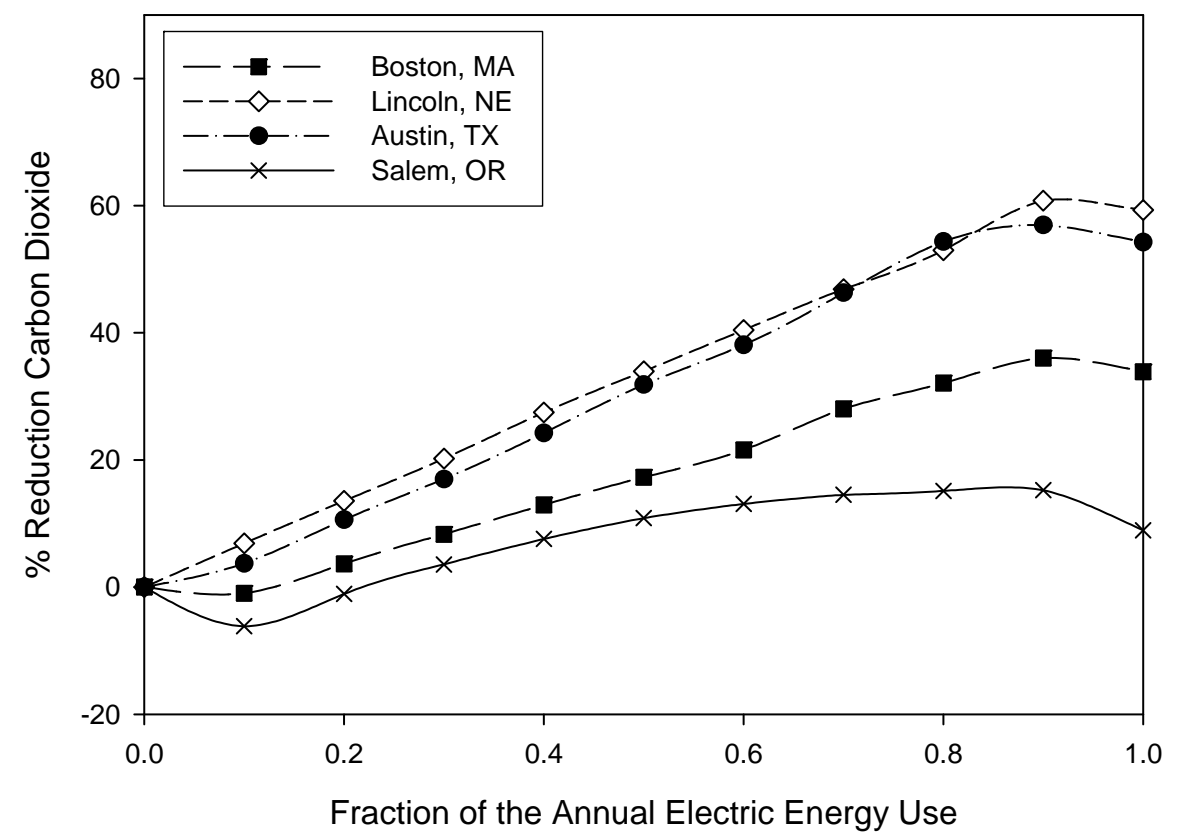

Figure 8. Reduction of emission of carbon dioxide $\left(\mathrm{CO}_{2}\right)$ 


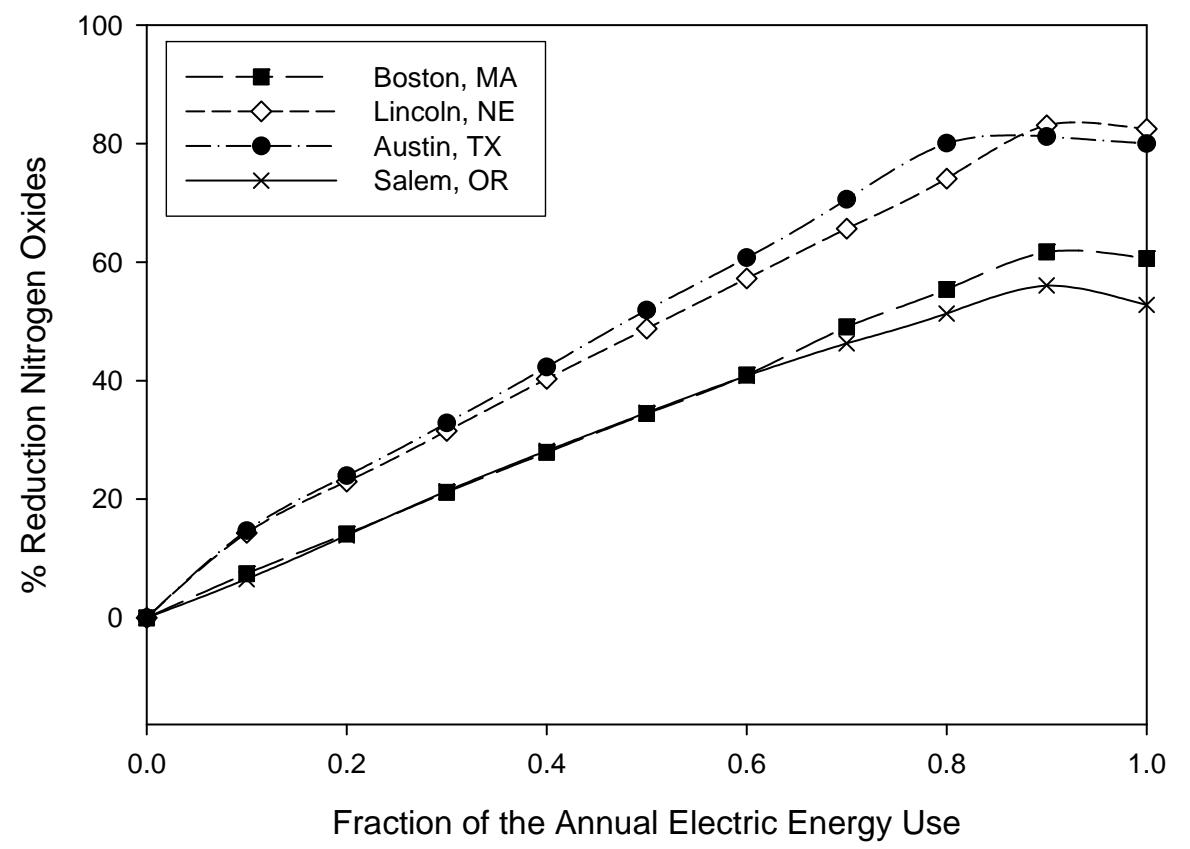

Figure 9. Reduction of emission of nitrogen oxides $\left(\mathrm{NO}_{\mathrm{x}}\right)$

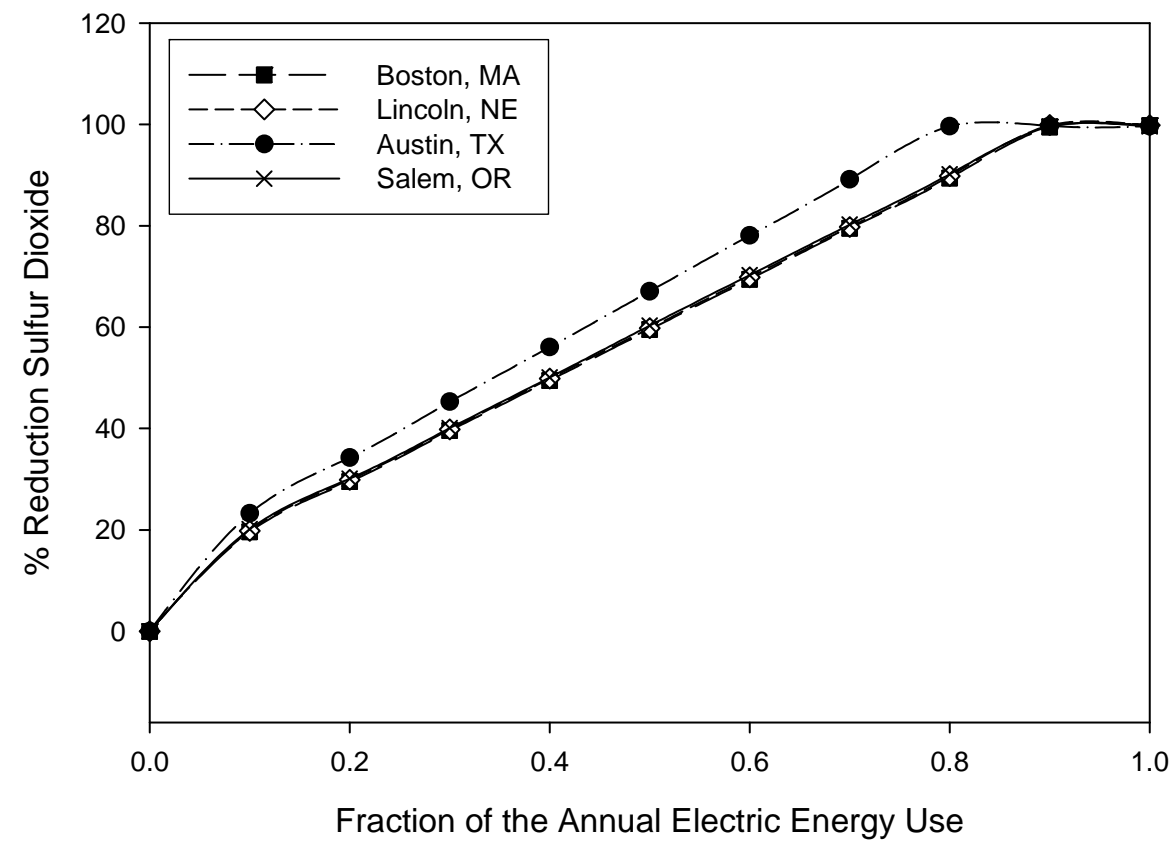

Figure 10. Reduction of Emission of Sulfur Dioxide $\left(\mathrm{SO}_{2}\right)$

\section{CONCLUSIONS}

A methodology to perform a non-conventional evaluation of CHP systems based on energy-efficient buildings and emission of pollutants has been presented. This methodology can be used to show and to quantify the benefits of CHP systems beyond standard economic analyses.

Since CHP systems reduce the consumption of energy sources, the buildings energy 
performance rating, in programs like Energy Star and Leadership in Energy and Environmental Design (LEED), can be improved. Using the methodology presented in this paper it can be demonstrated that the use of CHP systems can raise the Energy Star rating of a building above rating of 75 points. For the LEED Rating, CHP systems can help to obtain points through Credit 1 Optimize Energy Performance of the Energy and Atmosphere category. Also, an additional point can be obtained from Credit 5.4 -Performance Measurement: Emission Reduction Reporting.

It was also shown that CHP systems improve the overall building thermal energy efficiency while using less polluting energy sources. Therefore, CHP systems have the ability to significantly reduce emission of pollutants, which makes this technology a great tool to protect the environment while helping business to comply with environmental regulations. For the cities considered in this report, the use of CHP systems can reduce the emission of pollutants as much as $60 \%$ for carbon dioxide $\left(\mathrm{CO}_{2}\right), 82 \%$ for nitrogen oxides $\left(\mathrm{NO}_{\mathrm{x}}\right)$, and almost zero of sulfur dioxide. The emission reductions obtained from the use of CHP systems could be translated into economic values which makes CHP even more attractive not only from the environmental point of view, but also from the economical point of view.

\section{REFERENCES}

[1] Newborough, M. Assessing the benefits of implementing micro-CHP systems in the UK. IMechE Journal of Power and Energy, 2004, 218 (A4), 203-18.

[2] Keppo, I., and Savola, T. Economic appraisal of small biofuel fired CHP plants. Energy Conversion and Management. April 2007, 48 (4), 1212-21.

[3] Jablko, R., Saniter, C., Hanitsch, R., Holler, S. Technical and economical comparison of micro CHP systems. Future Power Systems, 2005 International Conference, Amsterdam, Netherlands, November 16-18 Nov. 2005.

[4] Tucker, C. T., Rethinking the benefits of CHP., Proceedings of the ASME Power Conference, 2005, Chicago, IL, United States, Apr 5-7 2005, pp. 891-898.

[5] De Paepe, M., D'Herdt, P., and Mertens, D. Micro-CHP systems for residential applications. Energy Conversion and Management. November 2006, 47(18-19), 343546

[6] Zoog, R. Cooling, Heating, and Power (CHP) for commercial buildings benefits analysis. Cogeneration and Distributed Generation Journal, 2004, 19(4), 14-44.

[7] Mago, P.J., Chamra, L.M., and Moran, A. Modeling of micro-cooling, heating, and power (Micro-CHP) for residential or small commercial applications. ASME International Mechanical Engineering Congress and Exposition (IMECE2006), Paper No. IMECE2006-13558, Chicago, Illinois, November 5-10, 2006.

[8] U.S. Environmental Protection Agency and the U.S. Department of Energy. Energy Star. Available online at: http://www.energystar.gov/

[9] U.S. Green Building Council (USGBC). Leadership in Energy and Environmental Design. Available online at: http://www.usgbc.org/DisplayPage.aspx? CategoryID $=19$

[10] ASHRAE, 2005 ASHRAE Handbook - Fundamentals, The American Society of Heating, Refrigerating and Air-Conditioning Engineers, Inc., Atlanta, Georgia, 2005.

[11]U.S. Environmental Protection Agency. Target Finder. Available online at: http://www.energystar.gov/index.cfm? $c=$ new bldg design.bus target finder 
[12] U.S. Green Building Council, October 2004. Green Building Rating System For Existing Buildings Upgrades, Operations and Maintenance. Version 2. Updated July 2005

[13] U.S. Environmental Protection Agency. Power Profiler. Available online at: http://www.epa.gov/powerprofiler/powerprofiler.htm

[14] Energy Information Administration's Office of Oil and Gas. The Natural Gas 1998: Issues and Trends, April 1999. DOE/EIA-0560 (98).

[15] ASHRAE, 2003 ASHRAE Handbook - Applications, The American Society of Heating, Refrigerating and Air-Conditioning Engineers, Inc., Atlanta, Georgia, 2003.

[16] Energy Information Administration. Computers and Photocopiers in Commercial Buildings, August 2002. EIA-DOE, 1999. Available online at: http://www.eia.doe.gov/emeu/cbecs/pc_copier/pccopier99.html

\section{EFFECT OF THE POWER GENERATION UNIT SIZE ON THE ENERGY PERFORMANCE OF COOLING, HEATING, AND POWER SYSTEMS}

\section{INTRODUCTION}

Increasing energy demand, increasing energy cost, and environmental concerns, are factors that continually dictates improvement and development of new technologies, and new energy and environmental legislation (policies and regulations) to promote energy saving and emissions reduction. Combined Cooling, Heating and Power (CHP) systems are becoming a response for addressing the current increased in energy demand and peak power issues [1]. CHP systems provide site or near site electric power generation, and thermal energy for heating and cooling purposes. The conversion of fuels to electricity by the Power Generation Unit (PGU) produces large quantities of waste heat that could be recovered by the thermally activated components of the CHP system. Heat for space and water heating is provided by means of heat recovery systems. Cooling is achieved using an absorption chiller driven by the recovered heat from the prime mover. When the recovered heat is not enough, a backup boiler provides the additional heat required by the absorption chiller to handle the cooling load. Since CHP systems generate the electricity onsite, losses due to transmission, and distribution, are considerably reduced compared with the electricity supplied by distant central power plants. While central power plants have a total efficiency between $30 \%-51 \%$, CHP systems are potentially $70 \%$ $85 \%$ efficient in utilizing fuels [2].

The design of CHP systems is not an easy task because the number and interrelationship of the variables involved. The variables include not only those related to the system itself but also those related to the building, such as the demand for power, heating, and cooling [3-6]. Therefore, this study focuses on the effect of the PGU size on the CHP performance. To consider the effect of building energy demand, the same building is evaluated for three different cities with different climate conditions.

For a CHP system design, the desired operation mode must be specified, which can be electric load following, electrically sized, or thermally sized [7]. The electrically sized operation mode is a baseloaded operation which opposes the main objective of this study. The thermally sized operation mode follows the thermal demand operation. This operation mode frequently results in more production of power than needed by the building, which requires either selling electricity to the grid or electric power storage. However, both options are beyond the scope of 
this paper. Thus, the electric load following operation mode was applied in the simulations performed in this research to obtain the results presented in this study.

Besides the operation mode, CHP systems should operate under an operational strategy. The most frequent operational strategy is cost-oriented, although a primary energy strategy yields a better energy performance. A consulting firm presented a report on the energy use and economics of CHP systems in office buildings, hotels, and hospitals located in five cities in the U.S.A. [6]. The report presents an analysis to minimize operating costs through the "Smart" operational strategy. The "Smart" strategy determines the hourly operation of the CHP system that minimizes operating costs. The algorithm developed for this study to perform the analysis does not consider primary energy savings or emissions reduction to decide when to operate the CHP system [6]. Cardona and Piacentino [8] presented a summary of the most common evaluation criteria for combined heat and power plants and combined heat, cooling and power plants. They reported that the primary energy saving management strategy is the operational strategy that allows achieving maximum energy saving during the plant life cycle. Other studies [9-10] also consider primary energy as the appropriate criterion for evaluation of CHP systems. Therefore, in this study primary energy strategy was implemented in the model used for simulations in order to estimate the energy consumption.

Although the main goal of this study is the effect of the power generation unit size on the primary energy consumption of office buildings with CHP systems, for comparison purposes the results include site energy consumption. Also, to show the importance of a primary energy strategy in CHP systems, and also for comparison purposes, results are presented for the cases when the CHP system operates with and without the primary energy strategy.

\section{NOMENCLATURE}

BPER Building primary energy ratio

CHP Combined cooling, heating and power

COP Coefficient of performance

EIA Energy Information Administration

PES Primary energy strategy

PEC Primary energy consumption

PGU Power generation unit

SEC Site energy consumption

\section{SITE ENERGY}

The Energy Information Administration (EIA) [11] defines Site Energy Consumption (SEC) as "The Btu value of energy at the point it enters the home, building, or establishment, sometimes referred to as "delivered" energy." Therefore, SEC is referred to the energy consumed at the building doors, which is the energy use registered by the utility meters. When a CHP system is incorporated to the building, it changes the site energy consumption profiles mainly because: (a) the electric energy from the grid is substituted by electric energy from the power generation unit; (b) the electric energy consumed by the cooling system is substituted by fuel consumption; and (c) the fuel consumption for heating is substituted by heat recovered from the power generation unit.

\section{PRIMARY ENERGY}

The EIA [11] defines Primary Energy as "All energy consumed by end users, excluding 
electricity but including the energy consumed at electric utilities to generate electricity. (In estimating energy expenditures, there are no fuel-associated expenditures for hydroelectric power, geothermal energy, solar energy, or wind energy, and the quantifiable expenditures for process fuel and intermediate products are excluded.)", and Primary Energy Consumption (PEC) as "is the amount of site consumption, plus losses that occur in the generation, transmission, and distribution of energy." To estimate PEC the SEC is converted to PEC by using site-to-primary energy conversion factors. The conversion factors used in this study are: 3.343 for electricity, and 1.047 for natural gas. These values were obtained using Target Finder [12].

\section{ACTUAL BUILDING ENERGY COMSUMPTION}

To obtain hourly site energy consumption data a hypothetical building was simulated using the software EnergyPlus [13]. General description of the building is presented in Table 1. The same building was simulated using weather data for the cities of Tampa (FL), Chicago (IL), and San Francisco (CA), as representation of different climates in the U.S.A. These three different climates (cites) were chosen to determine the relationship between the PGU size and the building energy consumption profiles (electric and thermal energy demand).

Table 1. General Description of the Simulated Building Using EnergyPlus.

\begin{tabular}{|c|c|}
\hline Orientation & Aligned with North \\
\hline Building type & General Offices \\
\hline Area & $1156 \mathrm{~m}^{2}(34 \mathrm{~m} \times 34 \mathrm{~m})$ \\
\hline Glass area & $30 \%$ in each wall (windows and door) \\
\hline People & 115 for weekdays, 0 for weekend \\
\hline Occupancy schedule & $\begin{array}{l}\text { Until }^{\mathrm{a}} \text { (fraction) }^{\mathrm{b}}: 6(0), 7(0.1), 8(0.5), 12(1), \\
13(0.5), 16(1), 17(0.5), 18(0.1), 24(0)\end{array}$ \\
\hline Electric equipment & $15000 \mathrm{~W}$ \\
\hline Equipment schedule & Same as for occupancy \\
\hline Lights & $45,000 \mathrm{~W}$ \\
\hline Lights schedule & $\begin{array}{l}\text { Until }^{\mathrm{a}}(\text { fraction }) \text { b. } 6(0.05), 7(0.2), 17(1), 18 \\
(0.5), 24(0.05) \text {; for weekends } 24(0.05)\end{array}$ \\
\hline \multicolumn{2}{|l|}{ Thermostat schedule: } \\
\hline For heating & $\mathrm{Until}^{\mathrm{a}}$ (set point, $\left.{ }^{\circ} \mathrm{C}\right): 6(18), 22(22), 24(18)$ \\
\hline For cooling & $\mathrm{Until}^{\mathrm{a}}$ (set point, $\left.{ }^{\circ} \mathrm{C}\right): 6(28), 22(24), 24(28)$ \\
\hline
\end{tabular}

\section{BUILDING CHP-SYSTEM ENERGY COMSUMPTION}

The site energy consumption and the primary energy consumption, for the building-CHP system, were obtained using a simulation algorithm from a model developed at Mississippi State University [14]. Figure 1 illustrates a sketch of the building-CHP system arrangement used in the development of the model, while Figure 2 shows the block diagram for the developed buildingCHP system simulation. The values of the main variables required by the model are presented in Table 2. The basic conditions for the simulation algorithm to estimate the energy consumption are:

- The time step simulation is one hour. 
- The PGU size was increased in steps of $5 \mathrm{~kW}$ with a maximum size equal to the maximum demand based on the climate conditions for the specific city.

- The PGU stops (cutoff value) when the demand is lower than $25 \%$ of the nominal power.

- The size of the absorption chiller corresponds to the one that gives the best energy performance for the specific PGU size.

- When the recovered heat is not enough for the chiller to handle the cooling load, a boiler provides the additional heat required.

- Because the hot water use is so low for office buildings, the building heating demand is only for space heating.

- The recovered heat corresponds only to the useful heat, that is, the heat required by the absorption chiller, and heat required for space heating.

- The heat recovered and available for space heating will exist only when the recovered heat is greater than the chiller consumption.

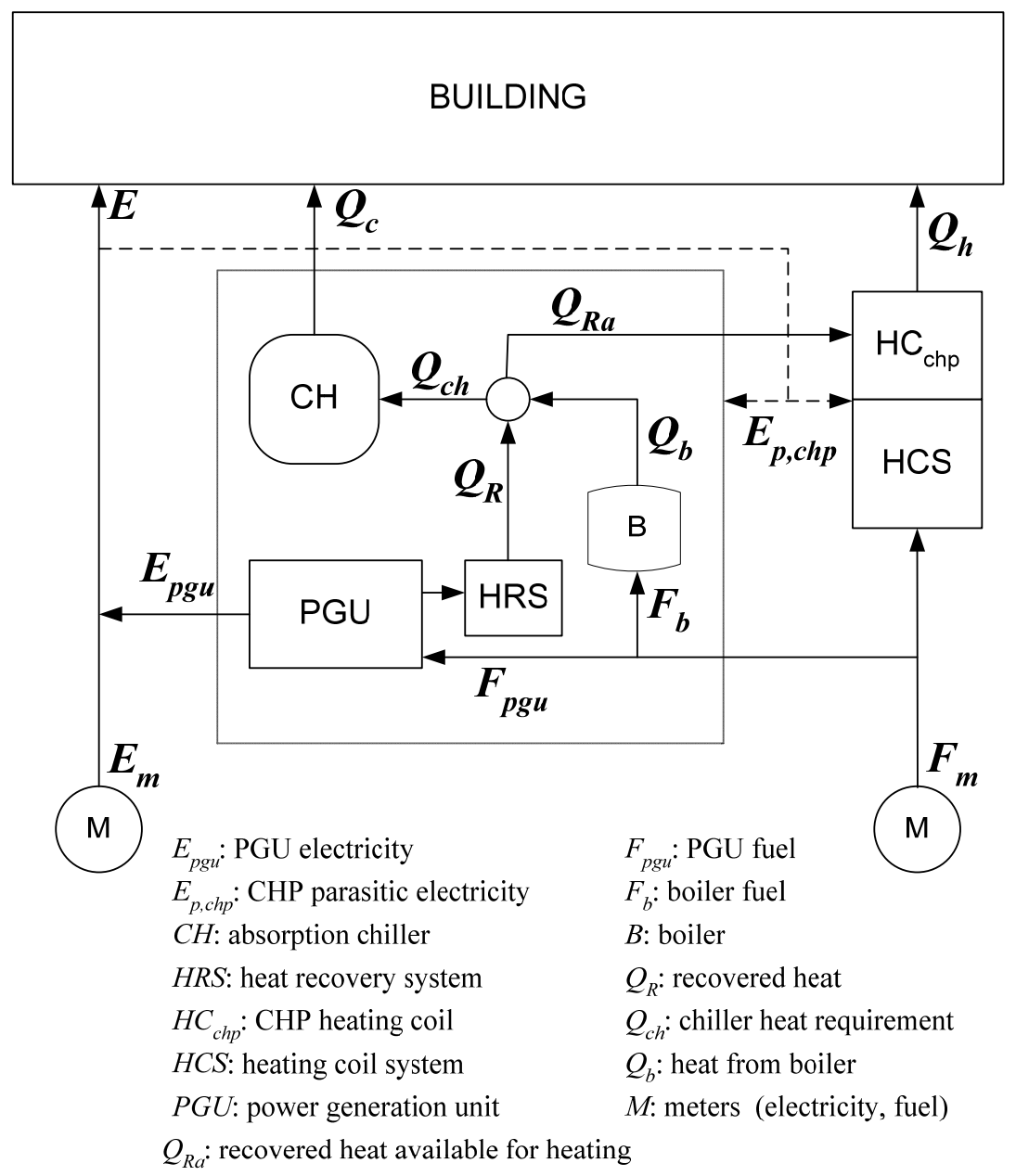

Figure 1. Schematic of the building-CHP system.

The model computes the primary energy consumption multiplying the site energy use, electricity and natural gas, by the respective site-to-primary energy conversion factors. 
Table 2. Variables employed for the energy consumption calculations.

\begin{tabular}{ll}
\hline Heat recovery system & 0.8 \\
Heating coil system efficiency & 0.8 \\
Boiler efficiency & 0.8 \\
Power generation unit (PGU) efficiency & 0.25 \\
Single effect absorption chiller COP & 0.7 \\
Vapor compression system COP & 3 \\
\hline
\end{tabular}

\section{PRIMARY ENERGY STRATEGY}

To evaluate the building-CHP system energy consumption under a primary energy operational strategy (PES), the parameter Building Primary Energy Ratio (BPER) was incorporated to the simulation algorithm. The BPER is defined as the ratio between the actual building primary energy consumption and the building-CHP system primary energy consumption. If the BPER is lower than 1, more primary energy is consumed when the CHP system operates, and if the BPER is higher than 1, primary energy is saved as consequence of the use of the CHP system. Thus, the BPER is used to determine when the CHP system has to operate in order to guarantee that primary energy is being saved. In the simulation algorithm, when the BPER is lower than 1, the CHP system is considered to be off and the site and primary energy consumptions are set equal to the actual building energy consumptions. For those cases when the PGU is off and the chiller has to operate, the boiler site and primary energy consumption are computed with the actual building energy consumptions. For the conditions when the BPER is higher than 1, the CHP system is considered to be operating and the site and primary energy consumptions are the calculated for the building-CHP system. For this study, the application of the BPER is considered and it is called as BPER strategy.

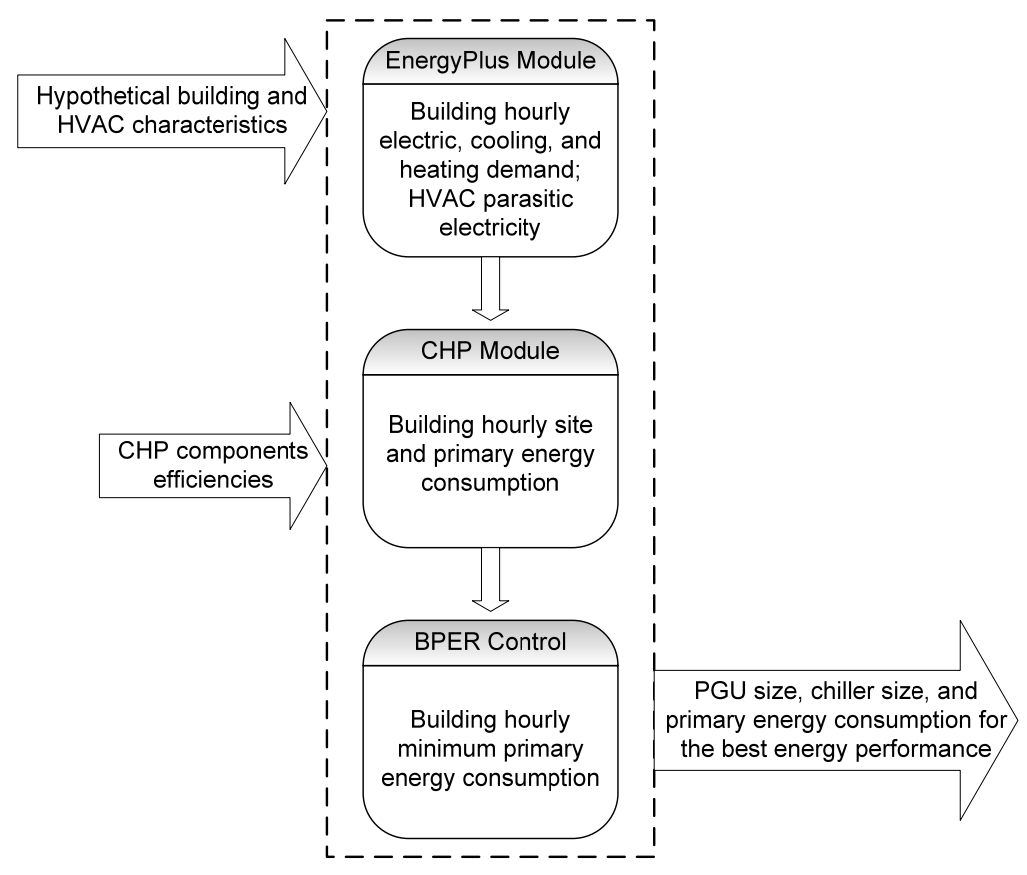

Figure 2. Block Diagram for the Building-CHP Simulation. 


\section{RESULTS AND ANALYSIS}

For the results presented in Figures 3 to 8, the actual building energy consumptions corresponds to the PGU size of zero, meaning that the CHP system is not installed.

Figure 3 and 4 show the site energy consumption as function of the PGU size for the cases when the CHP system operates without and with the BPER operational strategy, respectively. These figures demonstrate that the site energy consumption increases with the use of CHP systems. This increment occurs for all the sizes of the PGU. For the case when the CHP system runs under the BPER operational strategy, the SEC can be reduced when compared with the case without the BPER operational strategy. Based on the conditions of this study, the results presented in Figure 3 and 4 illustrate that if the CHP system operates under the BPER strategy the increment on the SEC can be reduced as much as 58\%, 28\%, and 54\%, for Tampa, Chicago, and San Francisco, respectively. Since economic evaluation is computed based on site energy prices, these results imply that less energy cost should be achieved when BPER operational strategy is implemented.

Figure 5 to 7 present the primary energy consumption as function of the PGU size for the cases when the CHP system operates without (CHP) and with the BPER operational strategy (CHP-BPER). These figures emphasize the importance of the primary energy operational strategy for CHP systems. For all three cities, when the CHP system operates under the BPER operational strategy, the primary energy never surpasses the reference value or actual building PEC. But if the BPER operational strategy is not applied, for high PGU sizes the PEC surpasses the actual consumption. For all three cities there is a PGU size that gives the lower primary energy consumption, which suggest that for any particular case there will be a PGU size that guarantee the maximum primary energy reduction.

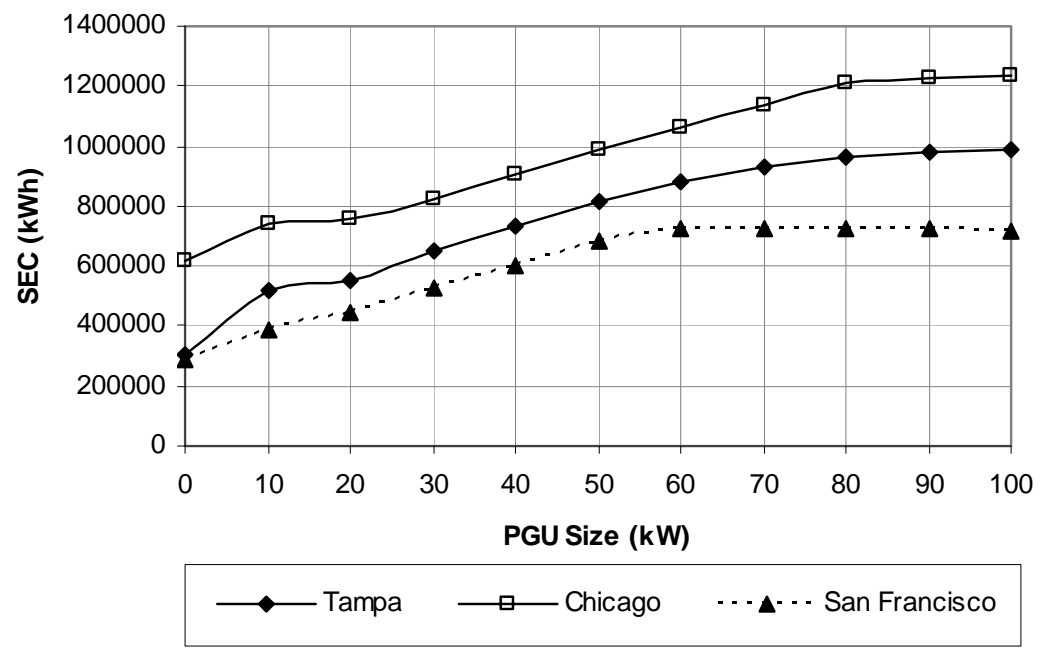

Figure 3. Site Energy Consumption as Function of PGU Size without Using the BPER Strategy. 


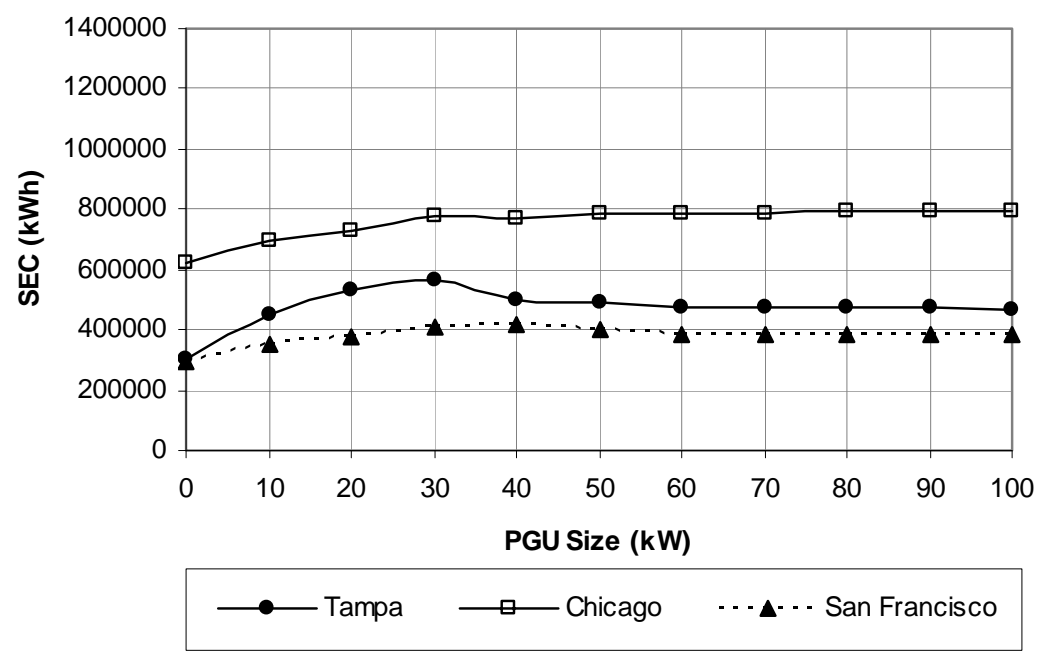

Figure 4. Site Energy Consumption for Primary Energy Strategy as function of PGU Size.

Figure 8 demonstrates the dependence of CHP systems performance on the building energy use profiles. This dependence was considered in this study by analyzing the same building for three different climate conditions (cities). The maximum PGU sizes are different for all three cities; $115 \mathrm{~kW}, 125 \mathrm{~kW}$, and $85 \mathrm{~kW}$, for Tampa, Chicago, and San Francisco, respectively. The maximum energy savings are obtained at different PGU sizes; $15 \mathrm{~kW}$ for Tampa and Chicago, and 10kW for the city of San Francisco. The PGU size from which the reduction of PEC remains constant is different for all three cities; $40 \mathrm{~kW}, 80 \mathrm{~kW}$, and $55 \mathrm{~kW}$, for Tampa, Chicago, and San Francisco, respectively.

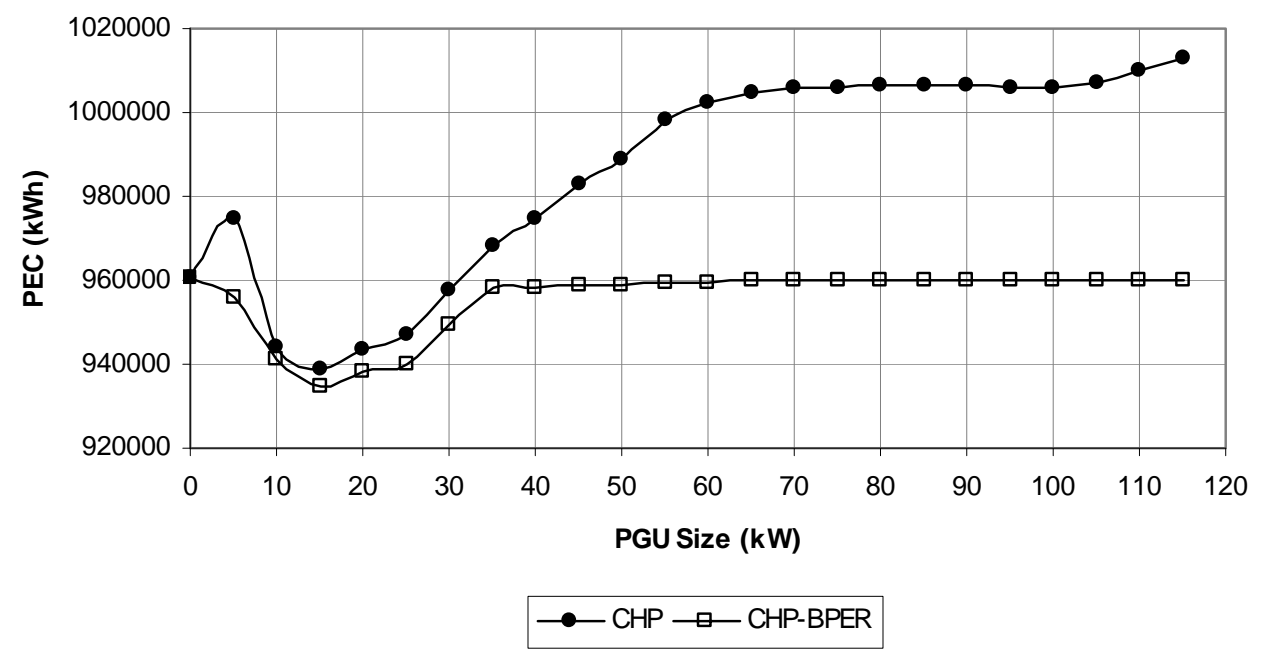

Figure 5. Primary Energy Consumption as Function of PGU Size for Tampa. 


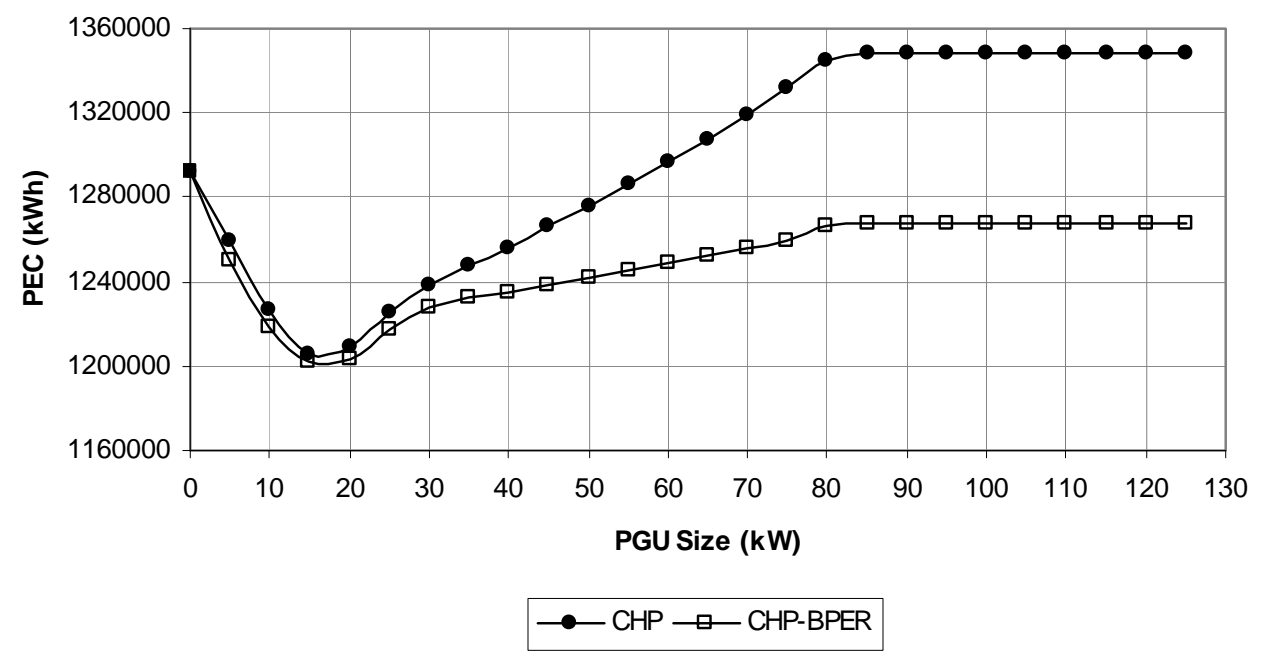

Figure 6. Primary Energy Consumption as Function of PGU Size for Chicago.

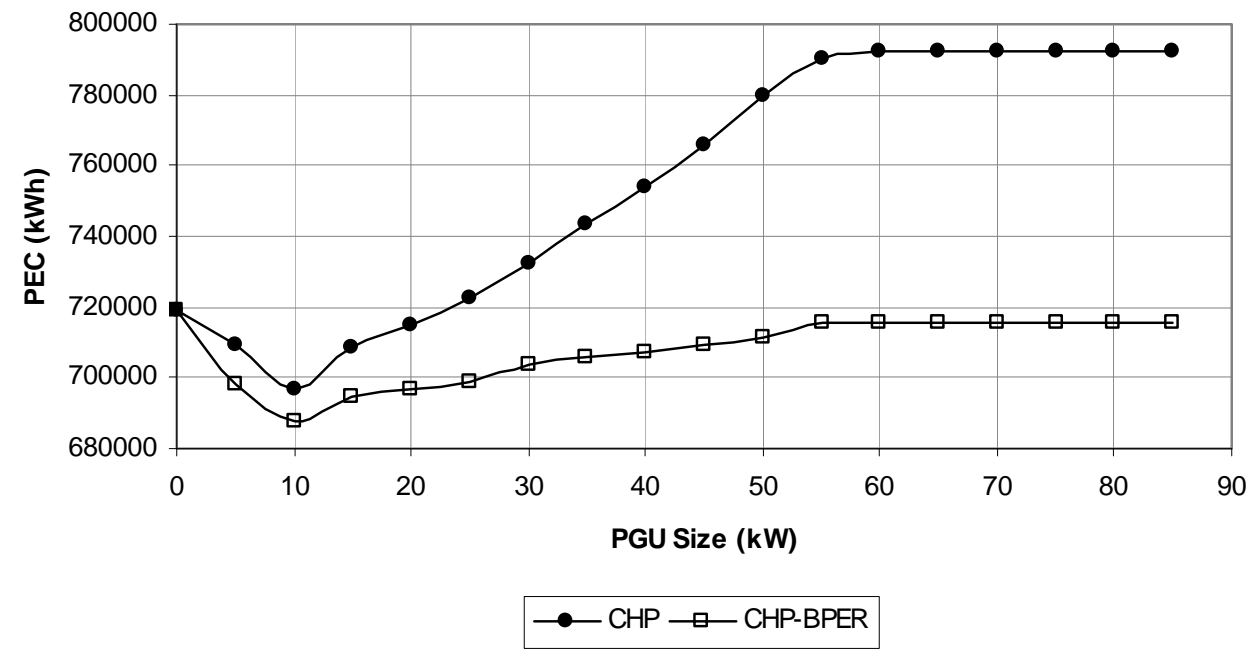

Figure 7. Primary Energy Consumption as Function of PGU Size for San Francisco.

Figure 8 suggest that although for the specified simulation conditions small sizes of the PGU size give better energy performance, every case should be analyzed independently in order to obtain the PGU size that maximizes the reduction of PEC. This figure also illustrates an interesting behavior, after certain value of PGU size, a bigger PGU will yield the same energy saving but will also yield higher costs associate to the size. 


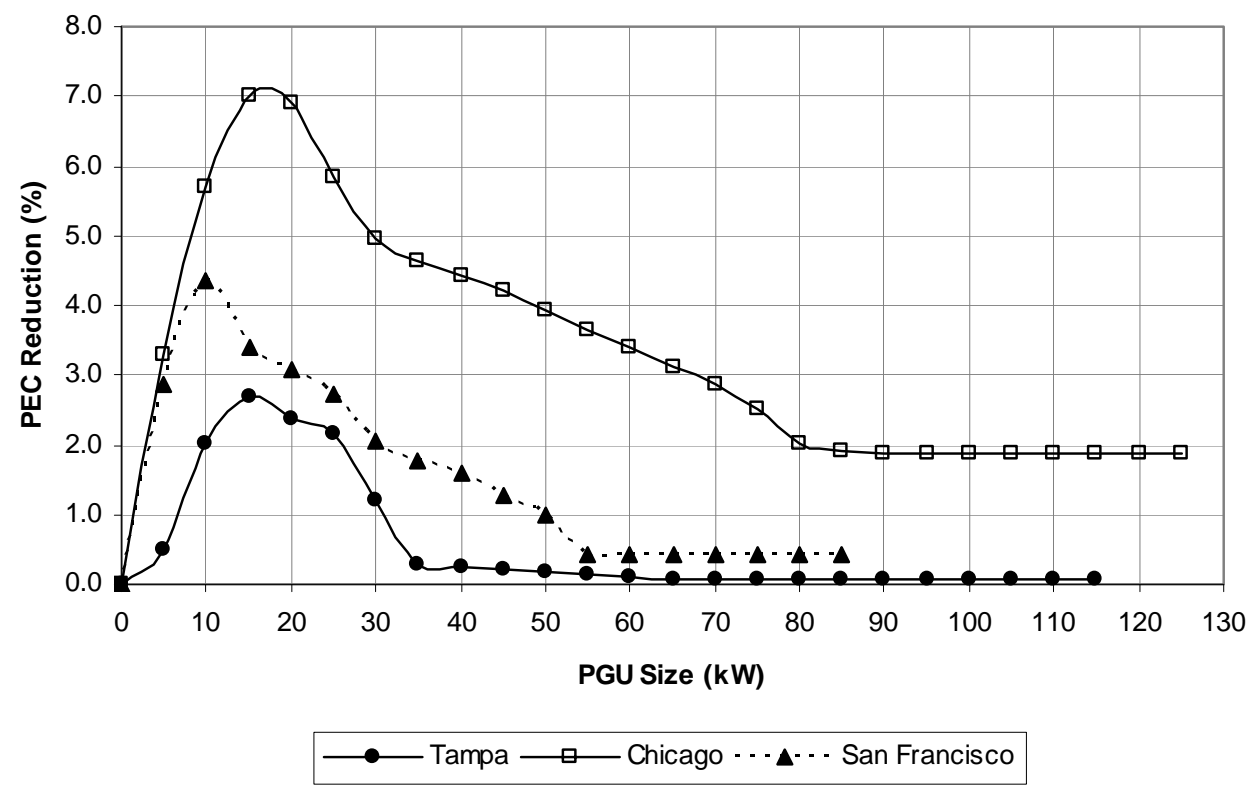

Figure 8. Primary Energy Consumption Reduction as Function of PGU Size.

As mentioned before, CHP systems performance depends on building energy use profiles and at the same time CHP system changes the site energy consumption patterns. The previous statement leads to the recommendation that, for CHP system design, to size the PGU a primary energy analysis should be performed and then the economic evaluation used to define the recommended size.

With respect to the benefits from the use of CHP systems, Figure 8 suggest that more energy savings can be reach for cold climates than for hot climates.

\section{CONCLUSIONS}

CHP systems running under the BPER operational strategy guarantee energy savings for any PGU size. Since CHP system energy performance depends on the building energy use profile, there is not a general reference size for the PGU in CHP systems. However, there is a PGU size that will guarantee the maximum energy savings for each application. Since each building has its own energy use profile as a consequence of the building characteristics, operation, and climate conditions, the PGU size analysis for CHP system becomes a unique analysis for each building-CHP system.

\section{REFERENCES}

[1] Rizy,D.T., Zaltash,A., Labinov, S.D., Petrov, A.Y., Vineyard, E.A., and Linkous. R.L. "CHP Integration (or IES): Maximizing the Efficiency of Distributed Generation with Waste Heat Recovery." Proceedings of the Power Systems 2003 Conference, Clemson, SC., 2003

[2] U.S. Department of Energy. "Energy Efficiency and Renewable Energy Agency." Federal Energy Management Program. DER/CHP. Available online at http://wwwl.eere.energy.gov/femp/der/index.html

[3] Sayane, S. and Shokrollahi, S. "Selection and Sizing of Prime Movers in Combined Heat and Power Systems." Proceedings of ASME Turbo Expo, 2004, pp. 613-621. 
[4] Combined Heat and Power for Buildings. Good Practice Guide. Actionenergy. Available online http://files.harc.edu/Sites/GulfCoastCHP/ProjectDevelopment/UKGoodPracticeGuide.pdf

[5] Zogg, R., Roth, K., and Brodrick, J. "Using CHP Systems in Commercial Buildings." ASHRAE Journal, September 2005, pp. 33-36.

[6] Arthur D. Little, Inc. "Cooling, Heating, and Power (CHP) for Commercial Buildings Benefits Analysis." Distributed Energy Program Report, 2002.

[7] Turner, W. Energy Management Handbook. 3er Edition, The Fairmont Press, Inc., 1997.

[8] Cardona, E. and Piacentino, A. "A Methodology for Sizing a Trigeneration Plant in Mediterranean Areas." Applied Thermal Engineering, 23, 2003, pp. 1665-1680.

[9] Sun, Z. G., Wang, R.Z., and Sun, W.Z. "Energetic Efficiency of a gas-engine-driven cooling and heating system." Applied Thermal Engineering, 24, 2004, pp. 941-947.

[10] Cardona, E. and Piacentino, A., "A Validation Methodology for a Combined Heating Cooling and Power (CHCP) Pilot Plant." Journal of Energy Resources Technology, 126, 2005, pp. 285-292.

[11] U.S. Department of Energy. Energy Information Administration. Glossary. Available online at www.eia.doe.gov

[12] U.S. Department of Energy, Environmental Protection Agency, EnergyStar Program. Target Finder. Available online at http://www.energystar.gov/index.cfm? $c=n e w \_b l d g \_d e s i g n . b u s \_t a r g e t$ finder

[13] U.S. Department of Energy, Energy Efficiency and Renewable Energy Agency, Building Technology Program. EnergyPlus. Energy simulation software free of charge available online at: http://www.eere.energy.gov/buildings/energyplus/

[14] Fumo, N., Mago, P., and Chamra, L., "CHP Energy Performance for System Feasibility." Journal of Power and Energy. Paper accepted for publication.

\section{BIOFUEL UTILIZATION}

The SERC project phase I for the Mechanical Engineering Department is divided into three major objectives. The first area includes theoretical work on the development of a first order thermodynamics-based phenomenological combustion model. The second objective is to procure, install, instrument and operate a single cylinder research engine on different biofuels such as biodiesel and bio-oil to obtain performance and combustion characteristics. The third objective comprises the development of a comprehensive framework for determining the model and experimental uncertainties described in the first two objectives. A detailed explanation of the subtasks performed to complete each objective during 2006-2007 follows:

Task 1: A detailed mathematical model of biomass/biofuel thermal processes and validation of the modeling results using proper experimental means will be performed. The validation of the model predictions is an essential part of the work. The proposed model will also consider the environmental regulations currently faced by industry.

\section{Proposed activities:}

1.1: Conduct extensive literature review of existing thermodynamic diesel engine combustion models with specific relevance to biofuels. 
1.2: Create a database of physical and chemical properties of various biodiesels and biodieseldiesel mixtures. These physical and chemical properties will be used in modeling combustion of pure biodiesel and biodiesel-diesel mixtures.

1.3: Develop first order biodiesel engine combustion model.

1.4: Validate the combustion model for engine performance using appropriate experimental results

1.5: Develop and validate a predictive NOx emissions model using Zel'dovich kinetics and integrate with combustion model developed in activity 1.3.

\section{Actual Accomplishments:}

- Activities 1.1 and 1.2 were completed by the end of November 2006. A summary of the papers, used to develop the literature review (Table A1 in Appendix), which addresses combustion modeling using thermodynamics based models in diesel engines and physical properties of various biodiesel blends has been prepared and will be continuously updated until the end of this project. From the literature review for subtask 1.1 and 1.2 a physical properties database (Table A2 in Appendix) has been developed. The review of combustion models and physical properties of fatty acid methyl ester blends that make up biodiesel form a sound basis for the development of a simple first order phenomenological thermodynamicsbased combustion model for biodiesel combustion.

- From the literature reviewed in activity 1.1, it was decided to develop a simple thermodynamic model based on assumed burn rates given by Wiebe functions. The various subroutines needed in this model were identified and a graduate student developed these subroutines in FORTRAN/Mathcad as part of his dissertation. This model is complete and has been validated against experimental results obtained from literature.

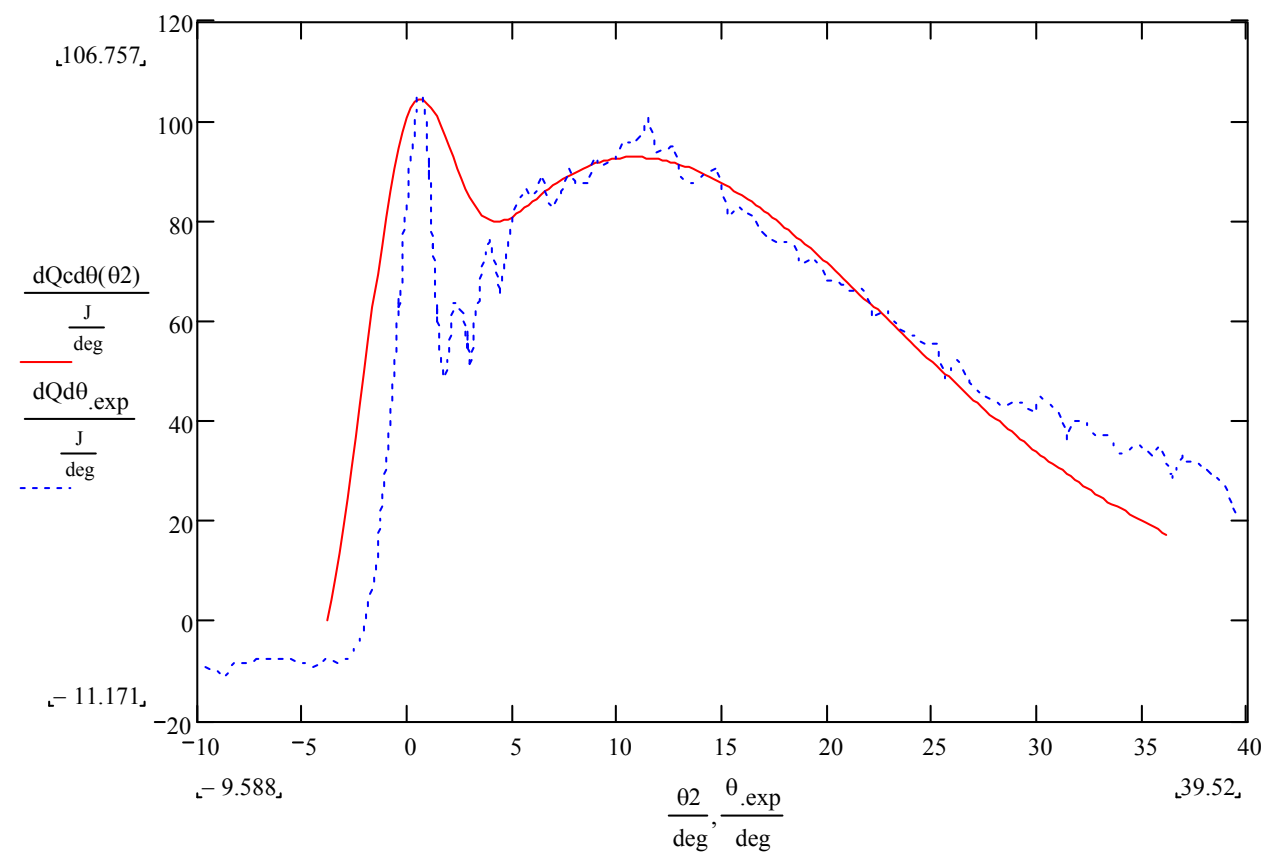

Figure 1: Sample results from Diesel Combustion model validated against experimental data. The uncertainty in the model is quantified in objective 3 of this report. 
- The first order biodiesel combustion model has been developed and validated against published experimental data. Detailed calculations on model sensitivity and experimental uncertainty have been performed. In particular, uncertainty bands for experimental heat release rates and simulated heat release rates were developed and a complete verification and validation of the simulation model to the experiments is complete. General recommendations were made regarding sensitive variables in modeling and experimental sensitivity.

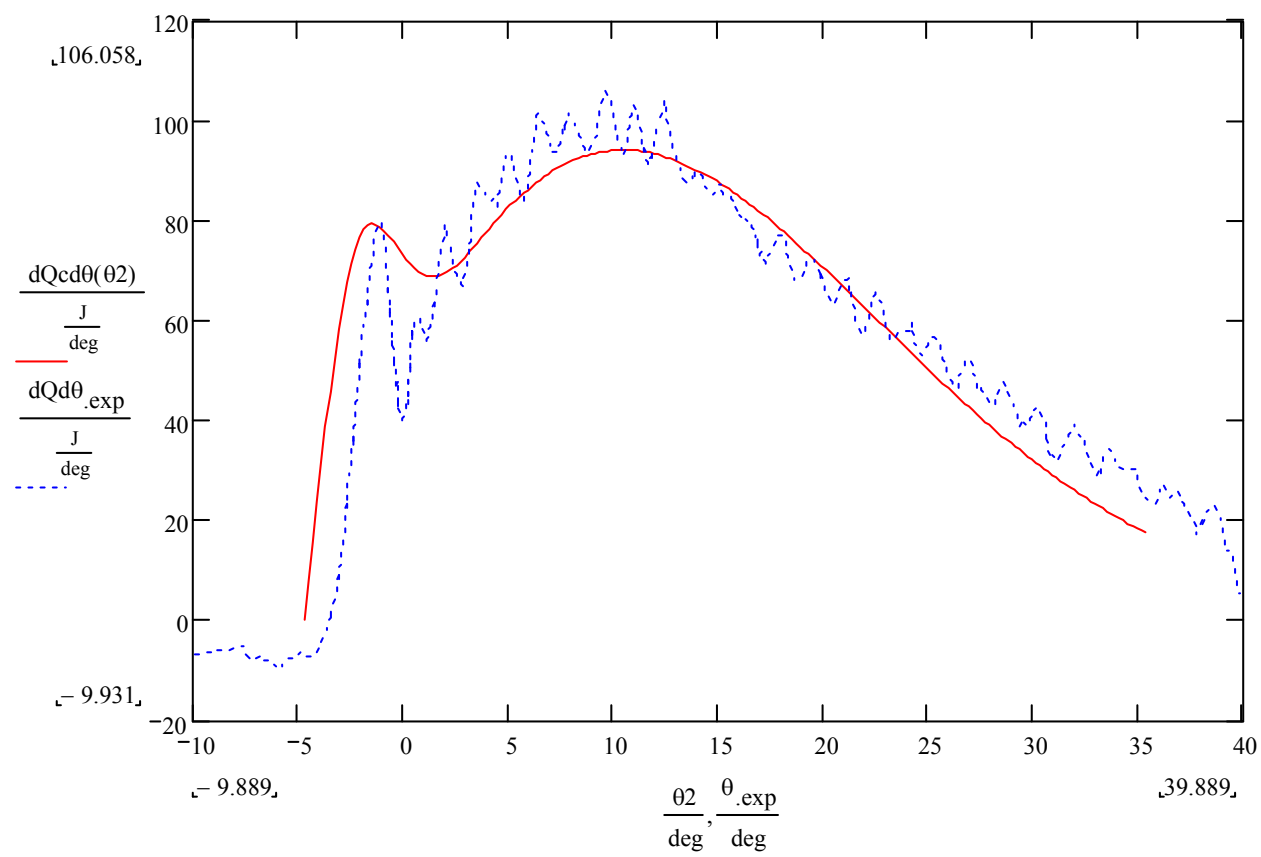

Figure 2: Sample results from BioDiesel Combustion model validated against experimental data. The uncertainty in the model is quantified in objective 3 of this report.

- A predictive NOx emissions model based on Zeldovich kinetics has been developed; however, since the NOx emissions are dependent on temperature, it was decided that the simple first order combustion model will prove inadequate to obtain any quantitative trends. Therefore, a more detailed phenomenological combustion model with sub-models for droplet evaporation, ignition delay and spray-air momentum exchange is currently being developed.

- A complete multizone physically based phenomenological model that includes important physics of spray combustion, droplet evaporation and ignition delay has been developed for diesel fuel. The model was developed in FORTRAN language and it is currently being debugged to obtain meaningful predictions against published experimental results.

\section{Activities planned for next quarter:}

1. Validate phenomenological combustion simulation against experimental data

2. Modify phenomenological simulation for biodiesel combustion

3. Tune model constants for biodiesel combustion and validated against experimental data from the open literature. 
Task 2. Experimentally study and analyze the different combustion processes of biomass fuel, i.e. syngas, direct burning of wood or garbage, biodiesel, bio-oil. These experiments will allow us to determine the energy efficiency of each process as well as the emissions generated during the combustion process. Also, valuable information about the use of biomass such as net efficiency of the energy conversion process will be evaluated in this section. A detailed uncertainty analysis of the experimental results will be performed in this part of the investigation.

\section{Proposed Activities:}

2.1: Procure and install a single-cylinder diesel engine, A.C. dynamometer and engine control system.

2.2: Instrument engine with the required temperature and pressure sensors, flow meters, and emission monitor.

2.3: Develop a digital data acquisition system with LabView interface to obtain real-time measurements from the engine.

2.4: Debug the various engine subsystems and ensure seamless integration of all mechanical and electrical components

Actual accomplishments:

- A Single Cylinder (compression ignited) Research Engine \has arrived on MSU campus. The following are the key specifications of the SCRE:

$>$ Mode of combustion - compression ignition

$>$ Displacement 1.875 L and baseline compression ratio 17:1

$>$ Optical module to visualize combustion in real-time has been procured in addition to the base engine described above

- An A.C. dynamometer with motoring capabilities has been ordered and the expected date of delivery is 18 weeks. The AC dynamometer will be installed and commissioned at the MSU combustion engines laboratory. The fidelity of coupling between the AC dynamometer and the SCRE will be tested.

- A completely flexible cooling and lubrication system for the SCRE has been ordered and this unit is expected to arrive on campus by March 2008. This unit will be coupled to the SCRE and commissioned along with the $\mathrm{A} / \mathrm{C}$ dynamometer.

- A "virtual engine" on paper has been instrumented and all the required measurements and devices have been identified. We expect to have all the support instrumentation including pressure and temperature sensors and flow meters ordered while the SCRE is being set-up.

- A LabView based cylinder pressure data acquisition program is already available. It is being modified to be compatible with the new engine hardware and later versions of labview.

Explanation of Variance: None

Planned Activities for Next Quarter:

1. Install and commission the A.C. dynamometer and perform initial fidelity tests of enginedynamometer coupling

2. Install and commission the SCRE and the cooling and lubrication system

3. Instrument the engine with appropriate pressure and temperature sensors and flow measurement systems

4. Develop a LabView based cylinder pressure data acquisition package 
Task 3. Uncertainty analysis of the developed models will be performed to determine the uncertainty associated with the comparison error between the model and experimental results. This uncertainty analysis will determine if further improvements or modifications need to be performed in the proposed model. In addition, uncertainty analysis will be used to determine which variable or variables have to be properly controlled to improve the performance of the combustion of biomass.

\section{Proposed Activities:}

3.1: Determine uncertainty of engine combustion model based on model input uncertainties

3.2: Determine combustion model validity

3.3: Perform general uncertainty analysis of engine test system.

3.4: Perform detailed uncertainty analysis of engine test system.

3.5: Determine uncertainty of baseline performance data

\section{Actual Accomplishments:}

- A general uncertainty analysis of experimental measurements has been completed and in a table of expected measured variables along with appropriate equations and an estimate of the range of uncertainties from the measurements has been generated. This general uncertainty analysis will also for the framework for a detailed uncertainty analysis, which will be complete once the engine is completely instrumented and ready for measurements.

Table 1: Expected uncertainty estimates in measurements form a general uncertainty analysis

\begin{tabular}{|ll|c|}
\hline \multicolumn{1}{|c|}{ Variable } & Estimated Uncertainty \\
\hline Engine Speed & $(\mathrm{N})$ & $0.1 \%$ of full scale \\
\hline Engine Torque & $(\tau)$ & $1.0 \%$ of full scale \\
\hline Fuel Mass Flow Rate & $\left(\mathrm{m}_{\mathrm{dot}}\right)$ & $\pm 1.0 \%$ of reading \\
& & $0.5 \%$ of full scale \\
\hline Flow Meter Frequency & $(\mathrm{f})$ & $0.5 \%$ of full scale \\
\hline Flow Meter Displacement & $\left(\mathrm{V}_{\mathrm{d}}\right)$ & $\pm 1.0 \%$ of reading \\
\hline Fuel Temperature & $(\mathrm{T})$ & $\pm 1.1{ }^{\circ} \mathrm{C}$ \\
\hline Fuel Pressure & $\left(\mathrm{P}_{\mathrm{r}}\right)$ & $1.5 \%$ of full scale \\
\hline Fuel Molecular Weight & $(\mathrm{M})$ & $0.5 \%$ of value \\
\hline $\begin{array}{l}\text { Fuel Gas Compressibility } \\
(\mathrm{Z})\end{array}$ & Factor & $0.1 \%$ of value \\
\hline Fuel Lower Heating Value & $\left(\mathrm{Q}_{\mathrm{lh}}\right)$ & $0.5 \%$ of value \\
\hline
\end{tabular}

- A detailed V\&V sensitivity analysis of model parameters of the simple single zone combustion model developed in task 1 has been performed. Initial analysis reveals that the 
estimation of trapped in-cylinder mass and choice of specific heat ratio are critical to obtaining accurate predictions of engine performance parameters.

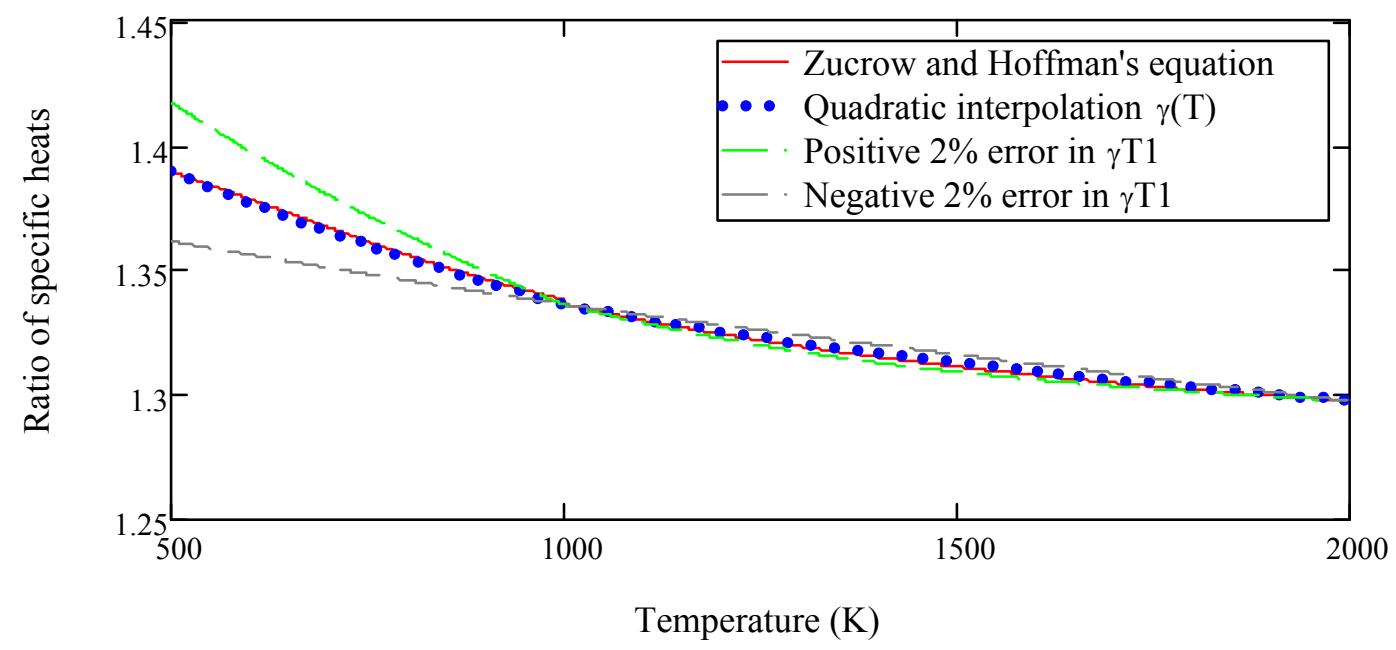

Figure 3: Ratio of specific heats as a function of temperature used in the uncertainty simulation

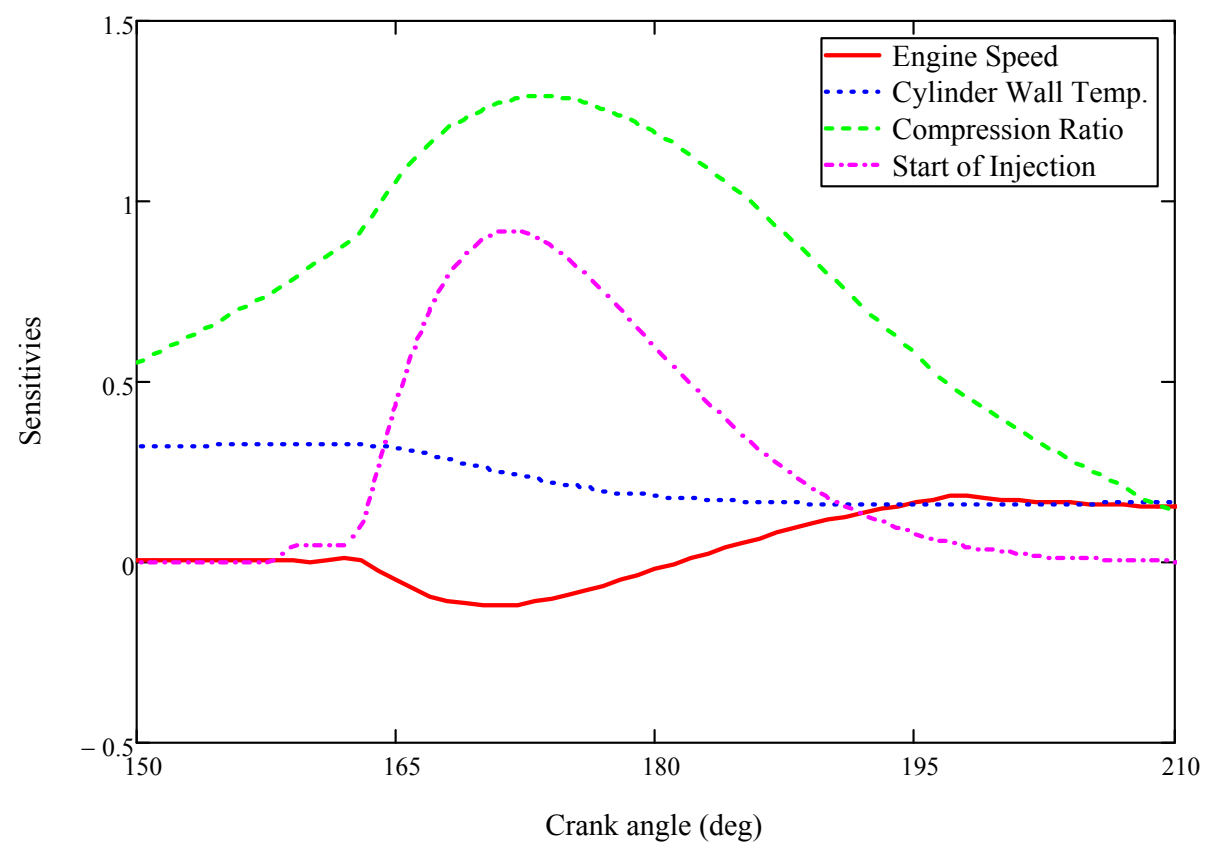

Figure 4: Sensitivities of selected engine parameters on the overall prediction of the cylinder pressure data using a one zone diesel combustion model 


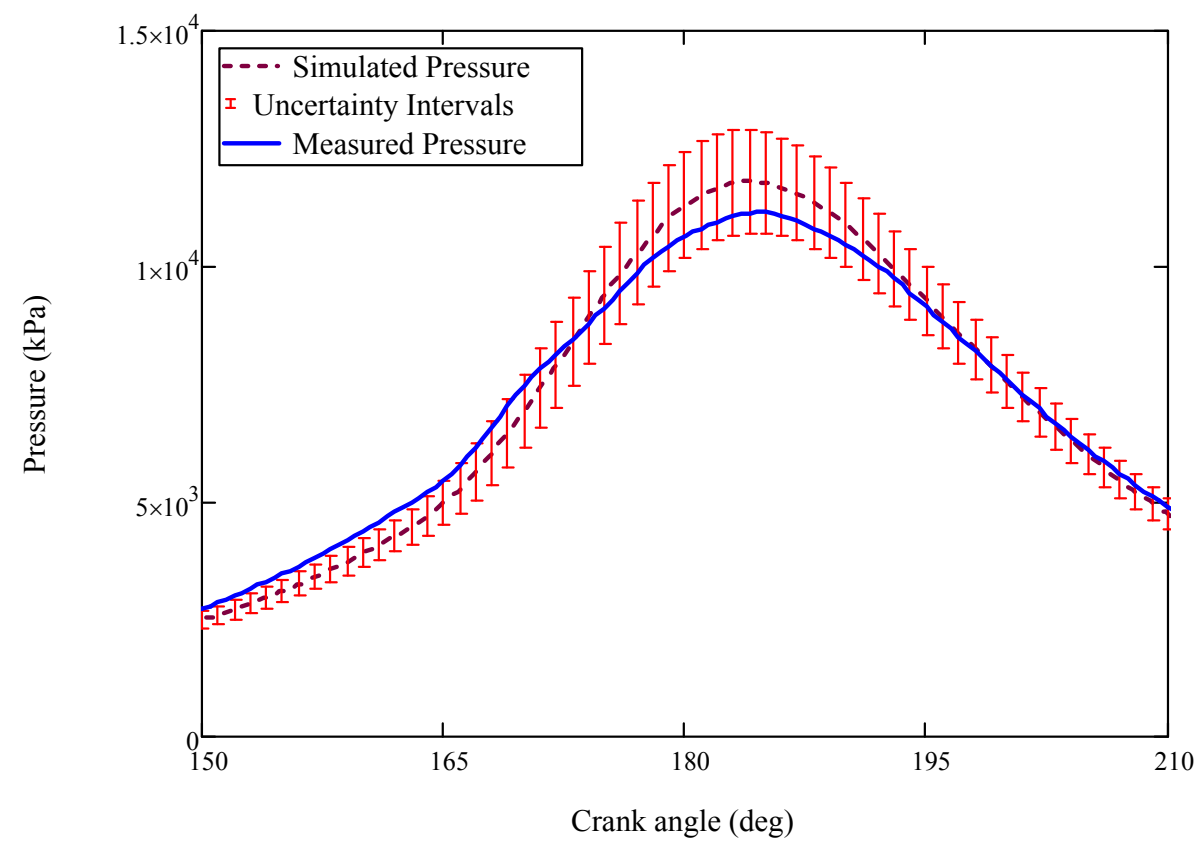

Figure 5: Uncertainty estimates of in-cylinder pressure predictions from the one zone diesel combustion model and the relative comparison with experiments

Table 2: Uncertainty estimates from detailed uncertainty analysis predictions of cylinder pressure data

\begin{tabular}{|l|c|c|}
\hline Parameter & Nominal Value & Estimated Uncertainty \\
\hline Initial Pressure $\left(P_{o}\right)$ & $181 \mathrm{kPa}$ & $12.67 \mathrm{kPa}$ \\
\hline Initial Temperature $\left(T_{o}\right)$ & $348 \mathrm{~K}$ & $4.52 \mathrm{~K}$ \\
\hline Engine Speed $\left(N_{e}\right)$ & $1700 \mathrm{rpm}$ & $17 \mathrm{rpm}$ \\
\hline Cylinder Wall Temperature $\left(T_{w}\right)$ & $420 \mathrm{~K}$ & $21 \mathrm{~K}$ \\
\hline Compression Ratio $\left(r_{c}\right)$ & 14.5 & 0.508 \\
\hline Air Mass Flowrate $\left(\dot{m}_{a}\right)$ & $1.43 \mathrm{E}-3 \mathrm{~kg} / \mathrm{sec}$ & $1.43 \mathrm{E}-5 \mathrm{~kg} / \mathrm{sec}$ \\
\hline Fuel Mass Flowrate $\left(\dot{m}_{f}\right)$ & $0.0657 \mathrm{~kg} / \mathrm{sec}$ & $6.57 \mathrm{E}-4 \mathrm{~kg} / \mathrm{sec}$ \\
\hline Stoichiometric Fuel-Air Ratio $\left(F / A_{s}\right)$ & 0.0697 & $6.97 \mathrm{E}-4$ \\
\hline Lower Heating Value $(L H V)$ & 42000 & 420 \\
\hline Cylinder Bore $(b)$ & $0.13716 \mathrm{~m}$ & $1.3716 \mathrm{E}-5 \mathrm{~m}$ \\
\hline Cylinder Stroke $\left(s_{c}\right)$ & $0.16510 \mathrm{~m}$ & $1.6510 \mathrm{E}-5 \mathrm{~m}$ \\
\hline Connecting Rod Length $(l)$ & $0.26162 \mathrm{~m}$ & $2.6162 \mathrm{E}-5 \mathrm{~m}$ \\
\hline Start of Injection $(S O I)$ & $340 \mathrm{deg}$ & $0.5 \mathrm{deg}$ \\
\hline Intake Valve Close $(I V C)$ & $217 \mathrm{deg}$ & $0.5 \mathrm{deg}$ \\
\hline Burn Duration $\left(\theta_{d}\right)$ & $23 \mathrm{deg}$ & $0.5 \mathrm{deg}$ \\
\hline Wiebe efficiency factor $(a)$ & 1.832 & 0.01832 \\
\hline Wiebe form factor $(n)$ & 1 & 0.01 \\
\hline First Gamma Parameter $\left(\gamma_{T I}\right)$ & 1.389 & 0.04167 \\
\hline
\end{tabular}




\begin{tabular}{|l|l|l|}
\hline Second Gamma Parameter $\left(\gamma_{T 2}\right)$ & 1.336 & 0.04008 \\
\hline Third Gamma Parameter $\left(\gamma_{T 3}\right)$ & 1.298 & 0.03894 \\
\hline
\end{tabular}

- A detailed verification and validation of estimated heat release rate schedules from measured cylinder pressure data is complete. Salient conclusions from this study are listed below

a. Error propagation in heat release analysis of pilot ignited natural gas combustion has been presented.

b. Consistent with previous observations made by other researchers, it was found that the uncertainty in the cylinder pressure and ratio of specific heats were the largest contributors to the uncertainty in the rate of heat release.

c. The parameter that gives the largest UMF is $d P / d \theta$, for that reason extreme care should be taken in its evaluation.

d. It can be also concluded that small errors in the measurement of the crank angle will result in large errors in the estimation of the rate of heat release. Therefore, extreme care should be taken in top dead center referencing.

e. The analysis also illustrates that without experimental data with associated uncertainty, no meaningful comparison can be made using the V\&V effort. The analysis presented in this paper can be employed to any engine to determine the effect of various measurements on performance metrics such as ROHR and imep. Also, the analysis presented here could lead to end-to-end V\&V examples comparing simulation and experimental results for parameters such as ROHR, imep, and peak pressure using variations of the test apparatus previously mentioned.

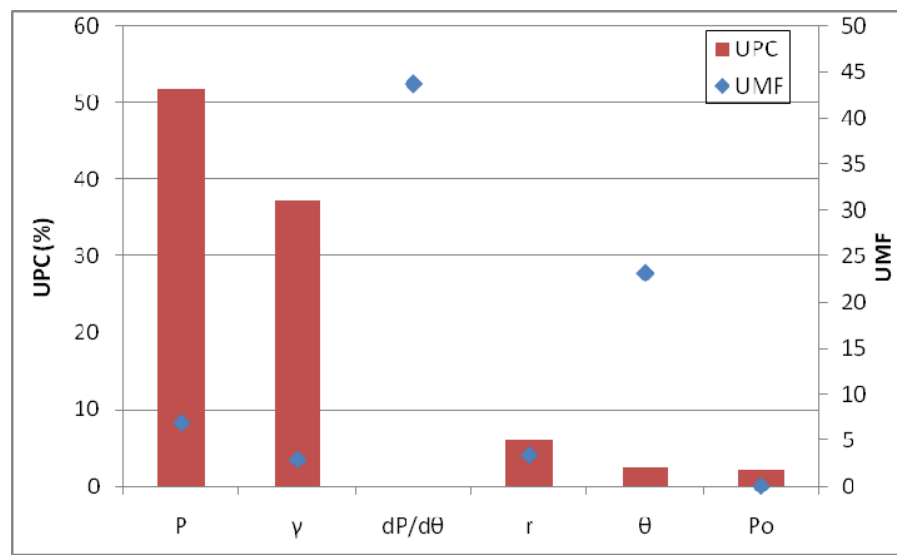

Figure 6: Uncertainty percent contribution (UPC) and Uncertainty magnification factor (UMF) contribution to in-cylinder rate of pressure rise data 


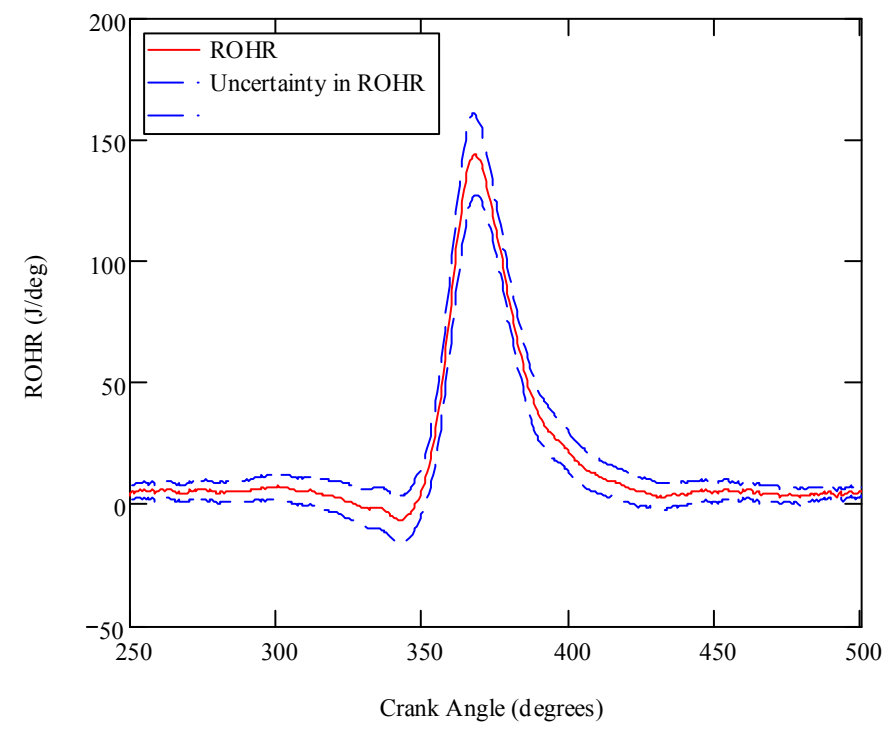

Figure 7: Uncertainty bands of Rate of Heat Release Rate (Upper and lower limits of uncertainty in heat release rate)

- A detailed uncertainty analysis for a first order biodiesel combustion model developed in Objective 1 is complete and a Verification and Validation (V\&V) has been completed for this model and the most sensitive modeling parameters and experimental variables have been identified. The next task is to extend the uncertainty analysis of the simple combustion model to the detailed phenomenological simulation that has been developed in objective 1 .

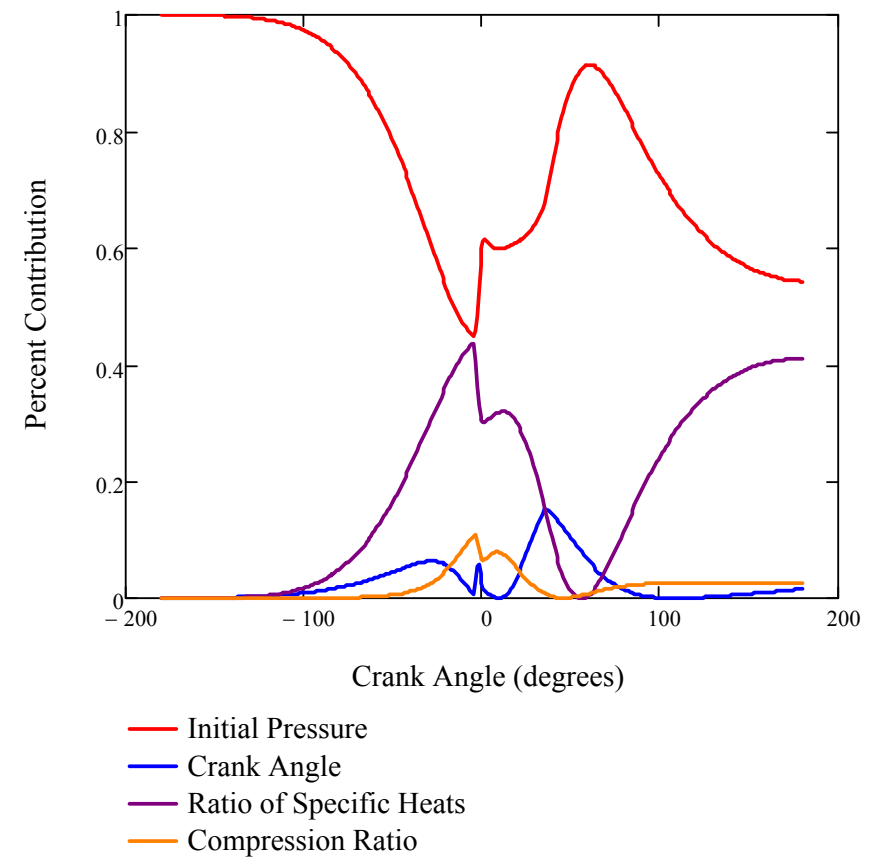

Figure 8: Detailed uncertainty propagation estimates of critical parameters that influence the accuracy of in-cylinder pressure predictions from a single zone biodiesel combustion model 


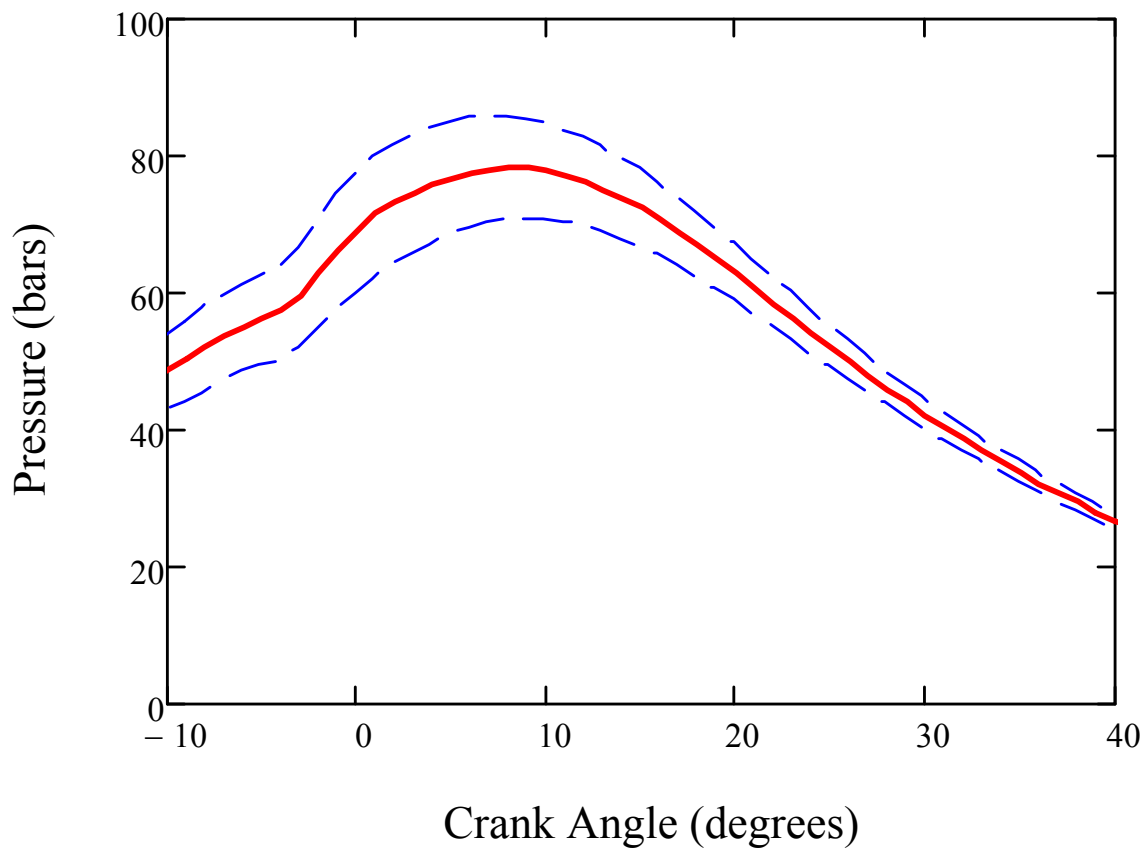

Figure 9: Uncertainty estimates of predicted single zone in-cylinder pressures relative to experimentally measured in-cylinder pressure. In particular, it is important to note the uncertainty bands, which encompass the range of acceptance of predictions from a valid mathematical combustion simulation model.

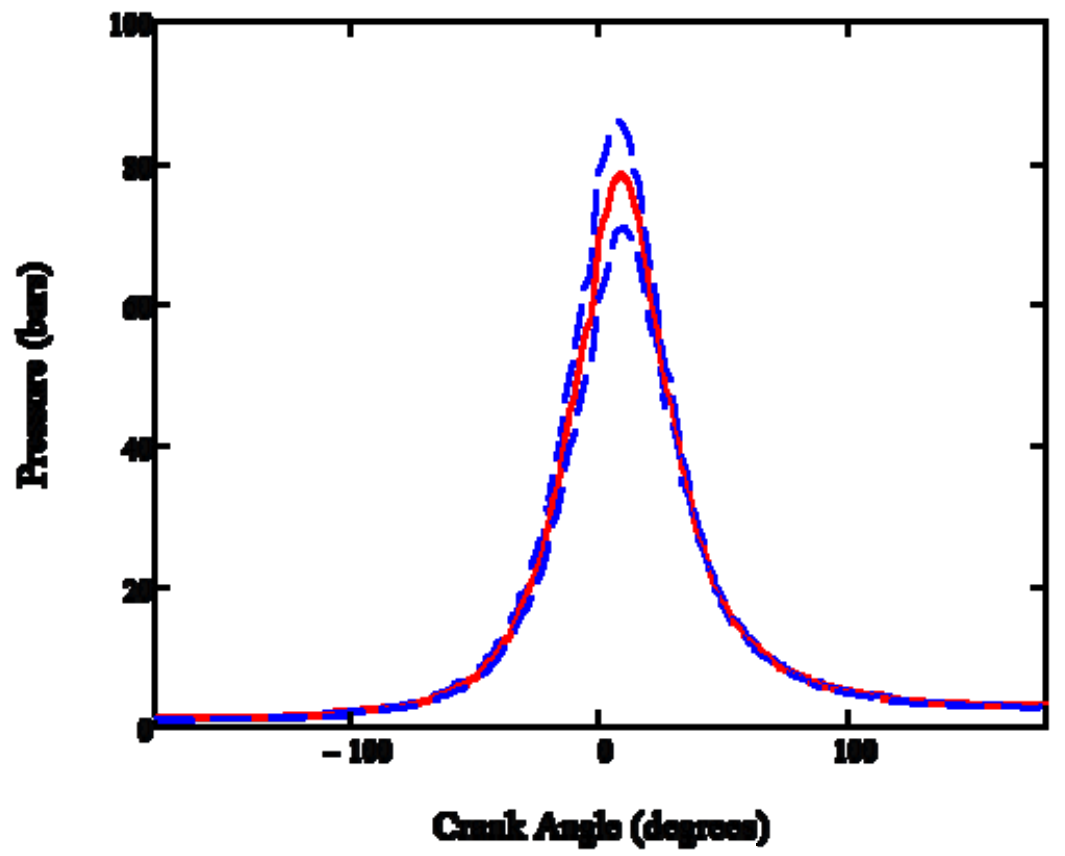

Figure 10: Uncertainty bands of Rate of Heat Release Rate (Upper and lower limits of uncertainty in heat release rate) Predictions from the Single Zone Biodiesel Combustion Model developed in Task 1.3 
Planned Activities for next quarter:

1. Extend the verification and validation of simple combustion model to the detailed phenomenological combustion simulation model being developed in task 1

2. Disseminate the complete findings of the error propagation analysis of heat release rates from experimental data in an archival journal

3. Develop a framework for uncertainty analysis of engine performance data. 
Table A.2. Summary of literature review for subtasks 1.1 and 1.2

\begin{tabular}{|c|c|c|c|c|c|c|c|c|}
\hline $\begin{array}{l}\mathbf{N} \\
\mathbf{0}\end{array}$ & $\begin{array}{l}\text { Yea } \\
\mathbf{r}\end{array}$ & Paper Title & Authors & $\begin{array}{l}\text { Journal } \\
\text { title } \\
\text { Conference } \\
\text { Proceeding } \\
\text { If website } \\
\text { (date } \\
\text { updated) }\end{array}$ & $\begin{array}{l}\text { Vo } \\
\text { l \# }\end{array}$ & $\begin{array}{l}\text { Issu } \\
\text { e \# }\end{array}$ & $\begin{array}{l}\text { Page } \\
\text { s }\end{array}$ & Salient observations and conclusions \\
\hline 1 & $\begin{array}{l}200 \\
6\end{array}$ & $\begin{array}{l}\text { Multizone modeling of } \\
\text { diesel engine fuel } \\
\text { spray development } \\
\text { with vegetable oil, } \\
\text { biodiesel or } \\
\text { diesel fuels }\end{array}$ & $\begin{array}{l}\text { C.D. } \\
\text { Rakopoulos, } \\
\text { K.A. } \\
\text { Antonopoulos, } \\
\text { D.C. } \\
\text { Rakopoulos }\end{array}$ & $\begin{array}{l}\text { Energy } \\
\text { Conversion } \\
\text { and } \\
\text { Managemen } \\
\mathrm{t}\end{array}$ & 47 & $\begin{array}{l}11- \\
12\end{array}$ & $\begin{array}{l}1150 \\
- \\
1573\end{array}$ & $\begin{aligned} & \Rightarrow \text { Multizone phenomenological model } \\
& \text { tracks spray development and } \\
& \text { evaporation histories of oxygenated } \\
& \text { fuels including biodiesel and } \\
& \text { vegetable oils. } \\
& \Rightarrow \text { Uses mean physical properties for } \\
& \text { biodiesel and vegetable oils from } \\
& \text { literature } \\
& \Rightarrow \text { Proposed spray development model } \\
& \text { is restricted only to the investigation } \\
& \text { of physical processes such as heat } \\
& \text { transfer, evaporation etc. } \\
& \Rightarrow \text { Does not include effect of fuel } \\
& \text { chemistry. } \\
& \Rightarrow \text { Model predicts that the progressive } \\
& \text { oxygen release from oxygenated fuel } \\
& \text { helps lean-out otherwise rich areas in } \\
& \text { the spray. This probably helps in the } \\
& \text { reduction of particulate matter (PM) }\end{aligned}$ \\
\hline
\end{tabular}




\begin{tabular}{|c|c|c|c|c|c|c|c|c|c|c|}
\hline 2 & $\begin{array}{l}200 \\
3\end{array}$ & $\begin{array}{l}\text { Computational study } \\
\text { of biodiesel ignition in } \\
\text { a direct injection } \\
\text { engine }\end{array}$ & $\begin{array}{l}\text { W. Yuan, } \\
\text { A.C. Hansen, } \\
\text { Q. Zhang }\end{array}$ & & $\begin{array}{l}\text { ASAE Paper } \\
036035 . \\
\text { ASAE } \\
\text { Annual } \\
\text { International } \\
\text { Meeting, } \\
\text { Las Vegas, } \\
\text { NV. , 27-30 } \\
\text { July } \\
2003\end{array}$ & & & & $\begin{array}{l}\Rightarrow \\
\Rightarrow \\
\Rightarrow \\
\Rightarrow\end{array}$ & $\begin{array}{l}\text { Multidimensional diesel combustion } \\
\text { model using KIVA } 3 \mathrm{~V} \text {. } \\
\text { Model uses Shell auto ignition model } \\
\text { to predict biodiesel ignition. } \\
\text { Single step kinetics is used to model } \\
\text { diesel combustion following ignition. } \\
\text { A major assumption that is made is } \\
\text { that biodiesel and diesel have the } \\
\text { same chemical ignition delays. } \\
\text { Cetane number variations with } \\
\text { biodiesel are considered by adjusting } \\
\text { shell model parametric constants }\end{array}$ \\
\hline 3 & $\begin{array}{l}200 \\
3\end{array}$ & $\begin{array}{lr}\text { Development } & \text { and } \\
\text { validation of } & \text { a } \\
\text { comprehensive } & \text { two- } \\
\text { zone model for } \\
\text { combustion } \\
\text { emissions formation in } \\
\text { a DI diesel engine }\end{array}$ & $\begin{array}{l}\text { C.D. } \\
\text { Rakopoulos } \\
\text { D.C. } \\
\text { Rakopoulos } \\
\text { D.C. Kyritsis }\end{array}$ & & $\begin{array}{l}\text { International } \\
\text { Journal of } \\
\text { Energy } \\
\text { Research }\end{array}$ & & 14 & $\begin{array}{l}1221 \\
- \\
1249\end{array}$ & $\begin{array}{l}\Rightarrow \\
\Rightarrow \\
\Rightarrow \\
\Rightarrow \\
\Rightarrow\end{array}$ & $\begin{array}{l}\text { A two zone model for the calculation } \\
\text { of closed cycle DI diesel is discussed. } \\
\text { Spray development process is } \\
\text { modeled using a time marching } \\
\text { algorithm. } \\
\text { The amount of oxygen entrained by } \\
\text { the spray is modeled using equations } \\
\text { that govern jet mixing. } \\
\text { The model basically defines two } \\
\text { zones, viz. burned and unburned. } \\
\text { The evolution of thermal Nox is } \\
\text { modeled using Zeldovich kinetics. } \\
\text { The temperature inputs for the Nox } \\
\text { calculations are provided by the } \\
\text { combustion model. The model } \\
\text { predictions are validated from } \\
\text { experiments conducted on a single } \\
\text { cylinder research engine. }\end{array}$ \\
\hline
\end{tabular}




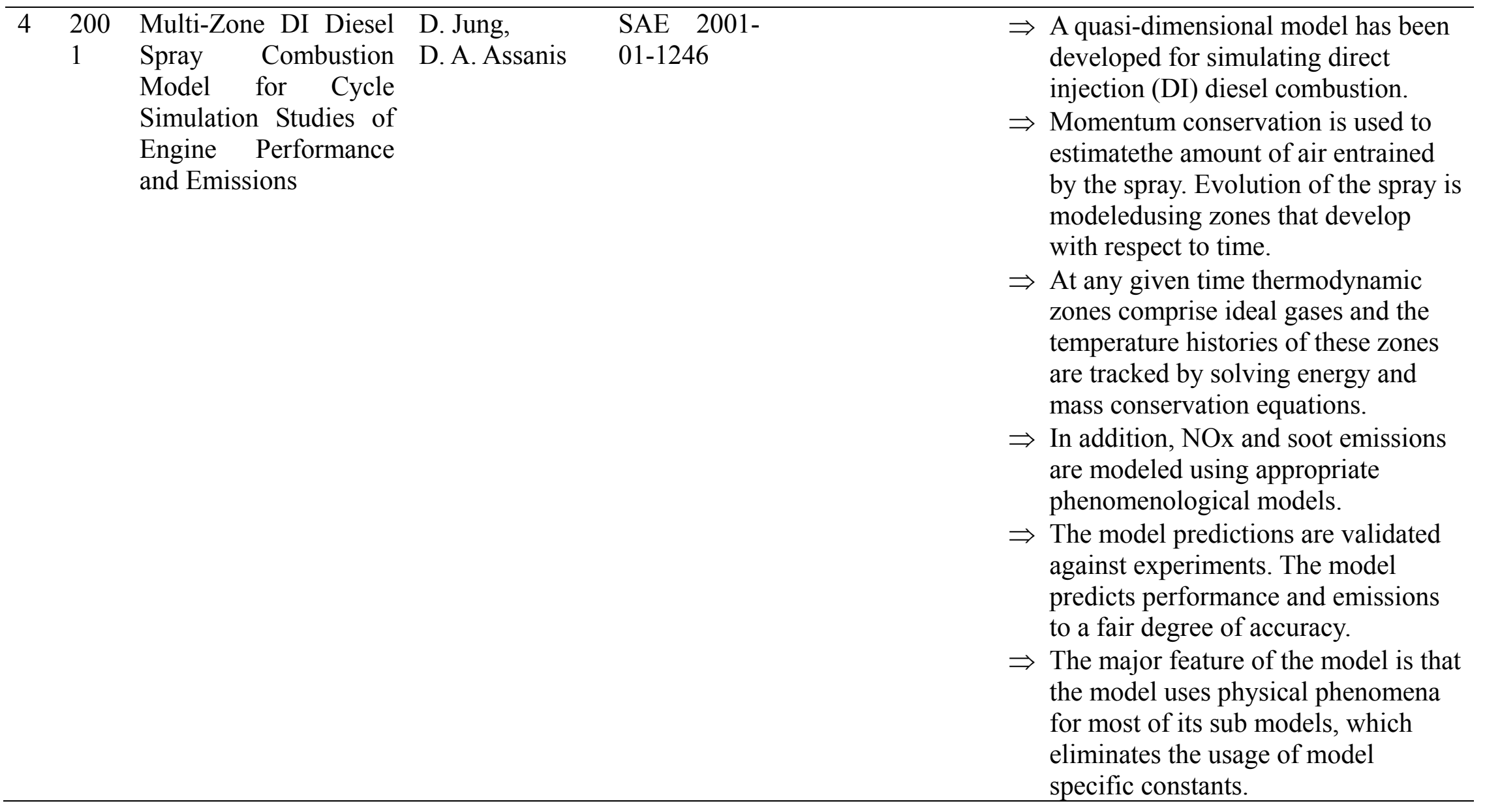




\begin{tabular}{|c|c|c|c|c|c|c|c|}
\hline 5 & $\begin{array}{l}198 \\
0\end{array}$ & $\begin{array}{l}\text { Modeling of a } \\
\text { stratified charge engine } \\
\text { with an un-scavenged } \\
\text { pre-chamber }\end{array}$ & $\begin{array}{l}\text { W. } \\
\text { Brandstetter }\end{array}$ & $\begin{array}{l}\text { Combustion } \\
\text { modeling in } \\
\text { reciprocatin } \\
\text { g engines } \\
\text { ed. C.A. } \\
\text { Amman \& J. } \\
\text { Mattavi, } \\
1980, \\
\text { Plenum } \\
\text { Press, NY }\end{array}$ & $\begin{array}{l}509- \\
536\end{array}$ & $\begin{array}{l}\Rightarrow \\
\Rightarrow \\
\Rightarrow \\
\Rightarrow \\
\Rightarrow \\
\Rightarrow\end{array}$ & $\begin{array}{l}\text { A mathematical model that simulates } \\
\text { gas flow and combustion in a single } \\
\text { cylinder pre-chamber engine. } \\
\text { The burn rates are approximated by } \\
\text { Wiebe functions for both the pre- } \\
\text { chamber and the main chamber. } \\
\text { Woschni's heat transfer model is used } \\
\text { to evaluate cylinder averaged heat } \\
\text { transfer. } \\
\text { Fuel injection is not modeled, it is } \\
\text { assumed that a fraction of the fuel is } \\
\text { injected into the pre-chamber and the } \\
\text { remainder into the main chamber. } \\
\text { The model is used to determine the } \\
\text { fraction burned in the pre-chamber } \\
\text { versus that burned in the main } \\
\text { chamber. } \\
\text { The model served as an important } \\
\text { developmental tool in designing } \\
\text { production engines by investigating } \\
\text { parameters such as ignition timing, } \\
\text { combustion duration, degree of } \\
\text { stratification and ratio of pre- } \\
\text { chamber to main chamber } \\
\text { combustion volume }\end{array}$ \\
\hline 6 & $\begin{array}{l}199 \\
1\end{array}$ & $\begin{array}{l}\text { Combustion process in } \\
\text { diesel engines }\end{array}$ & $\begin{array}{l}\text { T. Kamimoto, } \\
\text { H. Kobayahsi }\end{array}$ & $\begin{array}{l}\text { Progress in } 17 \\
\text { Energy and } \\
\text { Combustion } \\
\text { Science }\end{array}$ & $\begin{array}{l}163- \\
189\end{array}$ & $\Rightarrow$ & $\begin{array}{l}\text { This article summarizes studies on } \\
\text { fuel spray and air motion } \\
\text { characteristics, including optical } \\
\text { diagnostic techniques and } \\
\text { multidimensional numerical } \\
\text { calculation, which give valuable } \\
\text { insight into the complex phenomenon }\end{array}$ \\
\hline
\end{tabular}


regarding combustion-fluid dynamics interactions. Studies on combustion process and flame structure discerned that the combustion research focuses primarily on the mixing process and the formation of pollutants inside the combustion chamber.

$\Rightarrow$ It has been observed that investigation in detail is required in spray evolution in three-dimensional space.

$\Rightarrow$ It is also required to study the nonuniform structure specific to diffusion flames during combustion.

$\Rightarrow$ The uneven distributions of equivalence ratio, temperature and turbulence in the flame are responsible for the formation of NOx, hydrocarbon as well as the rate of heat release.

$\Rightarrow$ Laser sheet diagnostics can be useful in measuring the three-dimensional distributions of physical values.

$\Rightarrow$ Mathematical modeling of combustion can be helpful in depicting uneven structure resulting from turbulent mixing.

$\Rightarrow$ The flamelet model and pdf model together with stochastic mixing models can lead to the improvement of the existing models.

$\Rightarrow$ Use of alternate fuels demands investigation of ignition phenomena 
and the development of better

ignition technology.

$\Rightarrow$ Control of ignition delay can be one vital technology in this aspect.

7200 Detailed Chemical T. Kitamura, SAE 2001-

1 Kinetic Modeling of L. Takayuki,

Diesel Spray

Combustion

Oxygenated Fuels J. Senda,

with H. Fujimoto

\section{1-1262}

$\Rightarrow$ This paper examine the potentiality of soot free diesel jet combustion with oxygenated fuels in light of fuel mixture composition and fuel structure using a detailed chemical kinetic model. The chemical kinetic mechanism, which was combined with various proven chemical kinetic models including normal alkane oxidation, oxygenated hydrocarbon oxidation, and PAH formation, was developed. In this model, methanol, ethanol, dimethyl ether (DME), dimethoxy methane (DMM), and methyl butanoate were considered as oxygenated fuels, and additionally normal heptane was selected as a representative diesel fuel.

$\Rightarrow$ It was found that for all fuel components having the same carbonatom concentration, $\mathrm{PAH}$ yields in oxygenated fuel pyrolysis are much less than in normal heptane pyrolysis throughout temperature range investigated. Furthermore, maximum PAH yield (PYmax) remarkably decreases as the oxygen content of supplied fuel increases. As the 
fraction of molecular oxygen in fuel mixtures increases, PYmax

decreases, and additionally the temperature realm of the PAH

formation shifts to lower temperatures.

$\Rightarrow$ It is concluded that the potentiality of oxygenated fuel on the soot precursor formation is dominated by the molecular structure, as well as by the fuel oxygen content.

$\Rightarrow$ The suppression of small fuel fragments during the partial combustion process inside the diffusion flame sheath can be the key factor to realize the "sootfree" diesel jet flame. In the case of the mixed fuel with normal heptane and oxygenated compound, the reduction in soot precursor concentrations was found to be very similar for all of the oxygenated fuel additives. This is the reason why the reduction in $n$ heptane is a dominant factor for soot suppression regardless of kinds of oxygenated additives. 


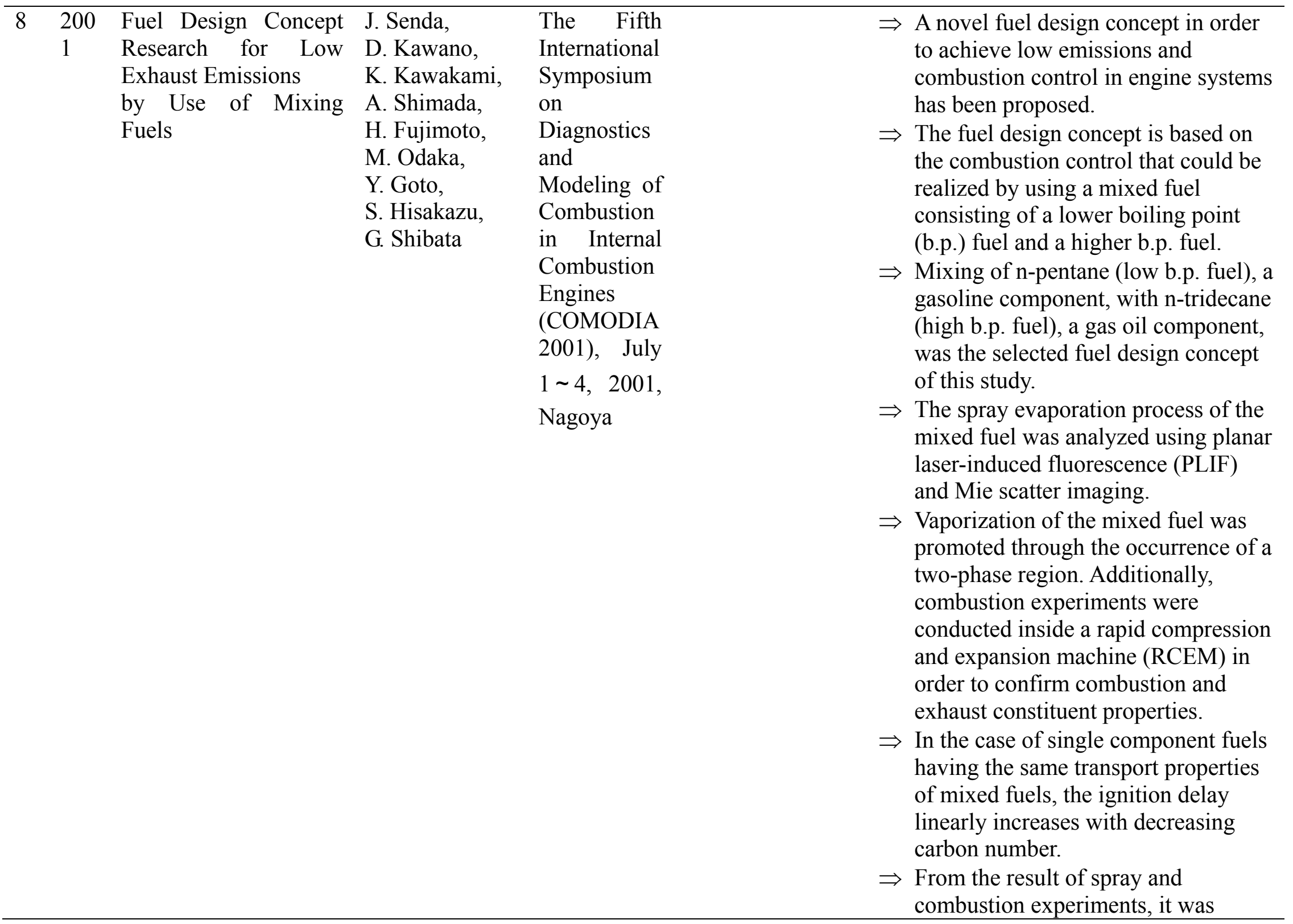


concluded that the maximum LIF

intensity of the mixed fuels

$(\mathrm{XC} 5 \mathrm{H} 12=0.25,0.5,0.75)$ is

dramatically decreased, compared to

that of pure n-tridecane, due to

improvement of vaporization

characteristics for mixed fuels.

$\Rightarrow$ Also it was found that the mixed fuels maintain a high ignitability even though the high ignitability fuel (n-tridecane) is diluted by the low ignitability fuel (n-pentane).

\begin{tabular}{|c|c|c|c|c|c|}
\hline 9 & $\begin{array}{l}200 \\
0\end{array}$ & $\begin{array}{l}\text { Detailed chemical } \\
\text { kinetic modeling of } \\
\text { diesel, combustion } \\
\text { with oxygenated fuels }\end{array}$ & $\begin{array}{l}\text { H.J. Curran, } \\
\text { E. M. Fisher, } \\
\text { P. A. Glaude, } \\
\text { N. M. Marinov, } \\
\text { W. J. Pitz, } \\
\text { C. K. } \\
\text { Westbrook, } \\
\text { P. F. Flynn, }\end{array}$ & $\begin{array}{l}\text { Fall } \\
\text { technical } \\
\text { meeting of } \\
\text { the (western } \\
\text { states) } \\
\text { Combustion } \\
\text { Institute, } \\
\text { Irvine, CA, }\end{array}$ & $\begin{array}{l}\Rightarrow \text { The present model calculations } \\
\text { confirm the view that some of the } \\
\text { products of the rich, premixed } \\
\text { ignition are species that lead } \\
\text { preferentially to soot production. } \\
\Rightarrow \text { The species acetylene, ethene and } \\
\text { propargyl radicals provide a useful } \\
\text { measure of the capacity of the }\end{array}$ \\
\hline
\end{tabular}




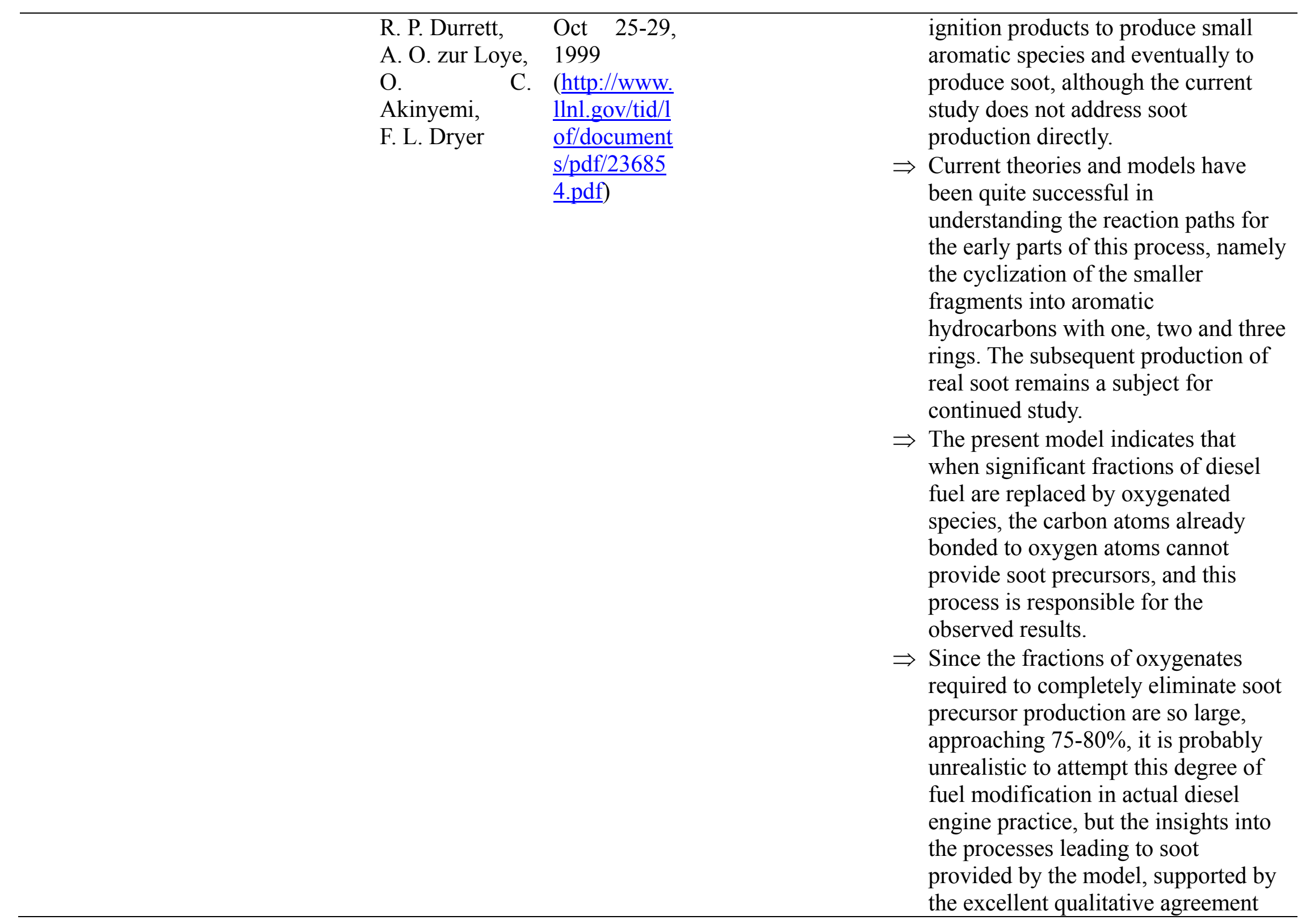


between experimental and model results, can be very valuable in future studies of diesel combustion chemistry

\begin{tabular}{|c|c|c|c|c|c|}
\hline $\begin{array}{ll}10 & 200 \\
& 4\end{array}$ & $\begin{array}{l}\text { A PDF method for } \\
\text { multidimensional } \\
\text { modeling of HCCI } \\
\text { engine combustion: } \\
\text { Effects of } \\
\text { turbulence/chemistry } \\
\text { interactions on ignition } \\
\text { timing and emissions }\end{array}$ & $\begin{array}{l}\text { Y.Z. Zhang, } \\
\text { E.H. Kung, } \\
\text { D.C. Haworth }\end{array}$ & $\begin{array}{l}\text { International } \\
\text { Multidimens } \\
\text { ional Engine } \\
\text { Modeling } \\
\text { User's } \\
\text { Group } \\
\text { Meeting } \\
\text { 2004, } \\
\text { Detroit, MI } \\
\text { (http://www. } \\
\text { erc.wisc.edu } \\
\text { /modeling/m } \\
\text { ulti_dimensi } \\
\text { onal/Modeli } \\
\text { ngMtng2004 } \\
\text { /agenda.html } \\
\text { ) }\end{array}$ & $\begin{array}{l}\Rightarrow \\
\Rightarrow \\
\Rightarrow \\
\Rightarrow \\
\Rightarrow\end{array}$ & $\begin{array}{l}\text { The aim of this research has been to } \\
\text { elucidate the role of } \\
\text { turbulence/chemistry interactions } \\
\text { (TCI) on HCCI auto-ignition and } \\
\text { emissions. } \\
\text { A state-of-the-art TCI model (a } \\
\text { transported probability density } \\
\text { function - PDF - method) has been } \\
\text { implemented in an unstructured-mesh } \\
\text { finite volume CFD solver, including } \\
\text { detailed chemistry. } \\
\text { The focus was on establishing trends } \\
\text { and sensitivities rather than on } \\
\text { quantitative comparison with } \\
\text { experimental measurements. } \\
\text { Variations in global equivalence } \\
\text { ratio, wall temperature, swirl level, } \\
\text { degree of mixture inhomogeneity } \\
\text { (premixed versus direct injection, and } \\
\text { start of-injection timing for direct- } \\
\text { injection cases), and a top-ring-land } \\
\text { crevice (TRLC) are investigated. } \\
\text { TCI is accounted for by considering } \\
\text { the joint PDF of } 40 \text { chemical species } \\
\text { and mixture enthalpy. For nearly } \\
\text { homogeneous reactants with low to } \\
\text { moderate swirl and no TRLC, TCI } \\
\text { has little effect on ignition timing. }\end{array}$ \\
\hline
\end{tabular}


However, even in that case the influence of TCI on emissions is not negligible.

$\Rightarrow$ With increasing levels of swirl, higher degrees of mixture inhomogeneity, and for cases that include a TRLC, TCI effects become increasingly important and result in significant changes in ignition timing, global in-cylinder temperature and pressure, and emissions.

$\Rightarrow$ Unburned fuel is a non-negligible contribution to UHC only in cases with high swirl or where a TRLC has been considered.

$\Rightarrow$ The combination of consistent hybrid particle/finite-volume algorithms, detailed chemical kinetics, and chemistry acceleration strategies make PDF methods practicable for three-dimensional time dependent modeling of HCCI auto-ignition and emissions.

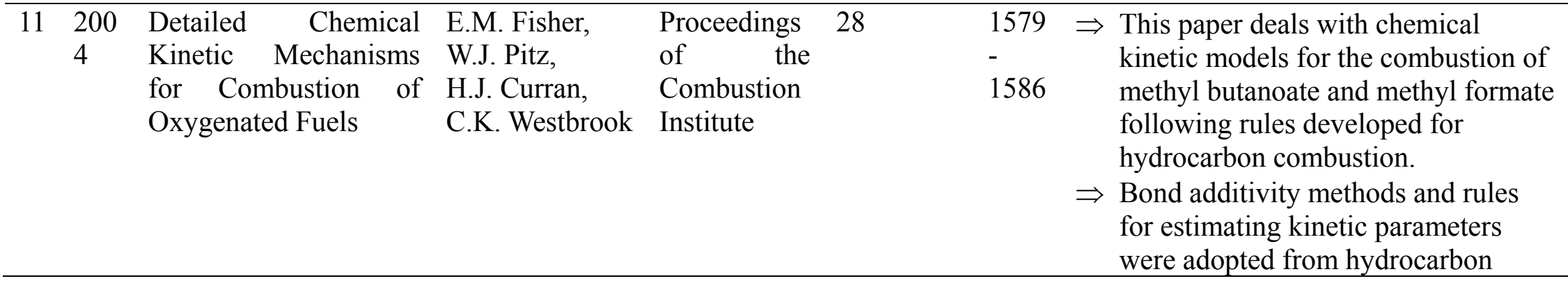


combustion and extended.

$\Rightarrow$ The mechanisms have been tested against the limited combustion data available in the literature, which was obtained at low temperature, subatmospheric conditions in static vessels, using pressure measurements as the main diagnostic. Some qualitative agreement was obtained, but the experimental data consistently indicated lower overall reactivities than the model, differing by factors of 10 to 50 .

$\Rightarrow$ This discrepancy, which occurs for species with well-established kinetic mechanisms as well as for methyl esters, is tentatively ascribed to the presence of wall reactions in the experiments.

$\Rightarrow$ The model predicts a region of weak or negative dependence of overall reaction rate on temperature for each methyl ester.

$\Rightarrow$ Examination of the reaction fluxes provides an explanation of this behavior, involving a temperaturedependent competition between chain-propagating unimolecular decomposition processes and chainbranching processes, similar to that accepted for hydrocarbons.

$\Rightarrow$ There is an urgent need to obtain more complete and well- 
characterized experimental data for thorough testing of the model.

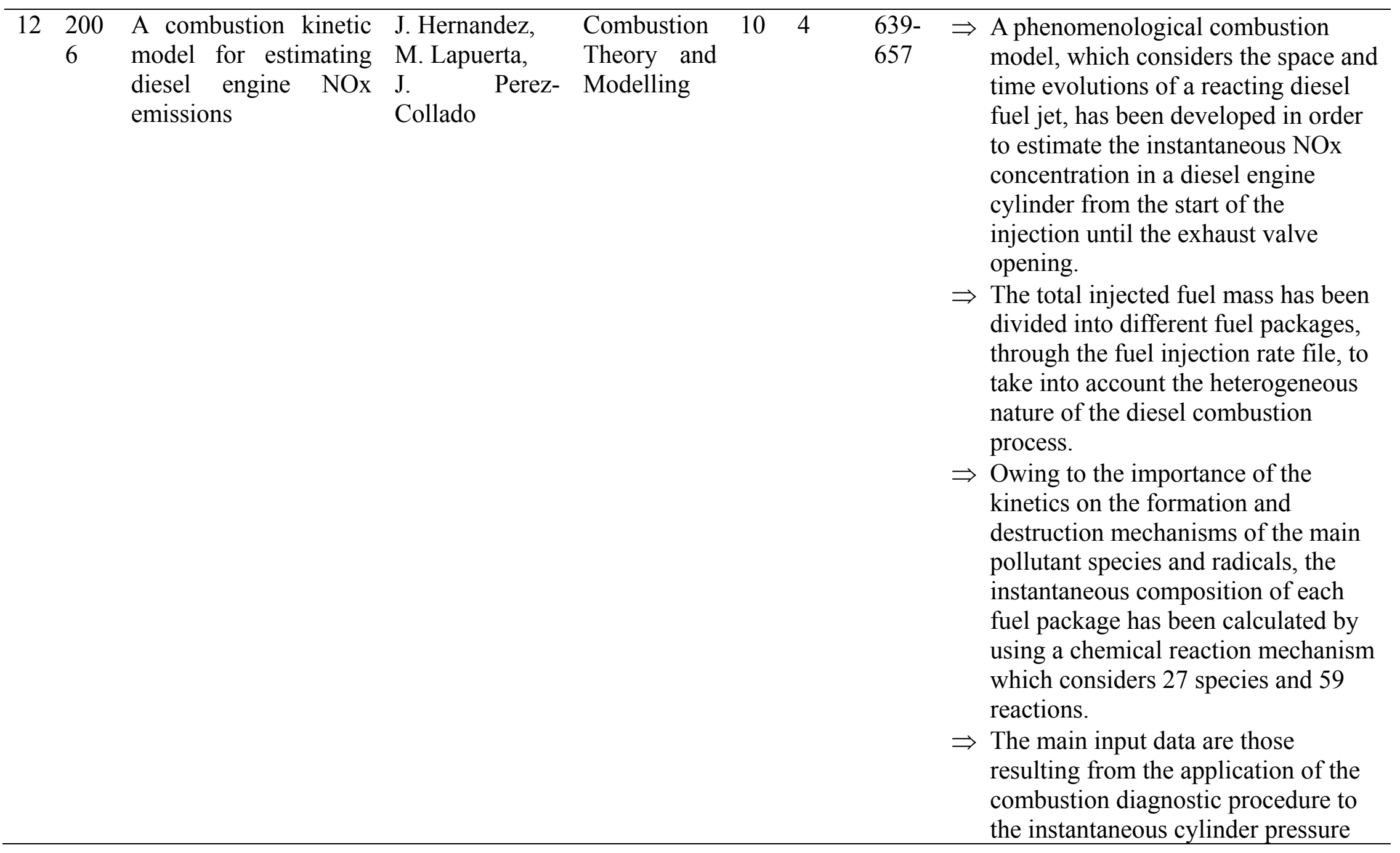


signal obtained during the engine tests, such as the heat release law (HRL) and the mean temperature.

$\Rightarrow$ A single-cylinder diesel engine was tested to validate the model and to analyze the influence of the injection parameters (injection pressure, injection timing and injected fuel mass) on the NOx emissions.

$\Rightarrow$ A good agreement between the theoretical results and the experimental ones was found when the engine conditions were modified.

$\Rightarrow$ The model proposed also allows a better knowledge of the local mixing fuel/air processes, which represent one of the most important uncertainties when modeling diesel combustion.

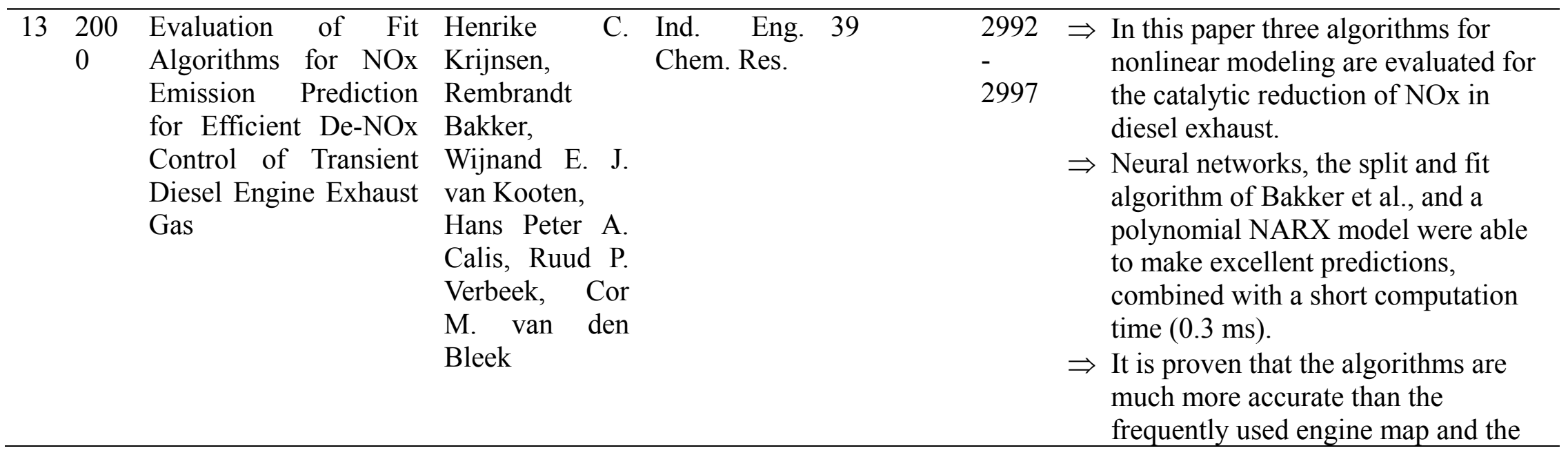




\begin{tabular}{|c|c|c|c|c|c|c|c|}
\hline & & & & & & & linear fit model. \\
\hline $\begin{array}{ll}14 & 200 \\
& 6\end{array}$ & $\begin{array}{lrl}\text { Analysis } & \text { of } & \text { H Ma, } \\
\text { combustion in a small } & \text { K Kar, } \\
\text { homogeneous charge } & \text { R Stone, } \\
\text { compression assisted } & \text { R Raine, } \\
\text { ignition engine } & \text { H Thorwarth }\end{array}$ & $\begin{array}{l}\text { International } \\
\text { Journal of } \\
\text { Engine } \\
\text { Research }\end{array}$ & 7 & 3 & $\begin{array}{l}237- \\
253\end{array}$ & $\begin{array}{l}\Rightarrow \\
\Rightarrow \\
\Rightarrow \\
\Rightarrow \\
\Rightarrow\end{array}$ & $\begin{array}{l}\text { The objective of this paper is to } \\
\text { develop a method to combine the } \\
\text { burn rate and heat release in order to } \\
\text { investigate the combustion process of } \\
\text { engines with premixed charge, but } \\
\text { ignited by compression. } \\
\text { The paper also deals with } \\
\text { investigation of combustion and } \\
\text { performance characteristics of } \\
\text { different nitromethane/methanol fuel } \\
\text { blends and investigation of } \\
\text { characteristics of different glow } \\
\text { plugs. } \\
\text { A small two-stroke glow ignition } \\
\text { engine, which has similar combustion } \\
\text { characteristics to homogeneous } \\
\text { charge compression ignition (HCCI) } \\
\text { engines, was used for conducting } \\
\text { combustion analysis. } \\
\text { The engine was fuelled with a } \\
\text { mixture of methanol, nitro-methane, } \\
\text { and lubrication oil. } \\
\text { The nominal spark timing and ratio } \\
\text { of specific heats specified in the } \\
\text { program have no significant effect on } \\
\text { the phasing of heat release. Nitro- } \\
\text { methane improves the initial and } \\
\text { main combustion rate of pure } \\
\text { methanol, beyond the uncertainty } \\
\text { created by the unknown mixture } \\
\text { strength and cycle-by-cycle }\end{array}$ \\
\hline
\end{tabular}


variations.

$\Rightarrow$ The indicated mean effective

pressure (i.m.e.p.) generally increases with increased nitro-methane content, only if the start of combustion occurs earlier so that the combustion phasing is approaching the optimum.

$\Rightarrow$ The combustion analysis has demonstrated that the glow plug has a marked effect in a very rich mixture ('0-4'). An optical study was recommended to investigate the effect of combustion. Finally, in the case of poor combustion, cycle-bycycle analysis showed that a misfire or partial burn cycles were always followed by high i.m.e.p. and fast burn cycles.

\begin{tabular}{|c|c|c|c|c|c|c|c|}
\hline $\begin{array}{ll}15 & 200 \\
& 6\end{array}$ & $\begin{array}{l}\text { A tabulated chemistry } \\
\text { approach for numerical } \\
\text { modeling of diesel } \\
\text { spray evaporation in a } \\
\text { "stabilized cool flame" } \\
\text { environment }\end{array}$ & $\begin{array}{l}\text { D.I. Kolaitis, } \\
\text { M.A. Founti } *\end{array}$ & $\begin{array}{l}\text { Combustion } \\
\text { and Flame }\end{array}$ & $\begin{array}{l}14 \\
5\end{array}$ & $\begin{array}{l}259- \\
271\end{array}$ & & $\begin{array}{l}\text { The paper utilized a tabulated } \\
\text { chemistry approach in conjunction } \\
\text { with a two-phase, Eulerian- } \\
\text { Lagrangian computational fluid } \\
\text { dynamics code to investigate the } \\
\text { locally occurring physico-chemical } \\
\text { phenomena in an atmospheric } \\
\text { pressure, diesel spray, stabilized cool } \\
\text { flame reactor. } \\
\text { To model spray evaporation in the } \\
\text { two-phase simulations, actual diesel } \\
\text { oil physical properties are used } \\
\text { whereas the corresponding chemistry } \\
\text { is represented by n-heptane. }\end{array}$ \\
\hline
\end{tabular}


$\Rightarrow$ A multitude of ideal perfectly stirred reactor simulations have been performed to generate the lookup table, utilizing a semi-detailed nheptane oxidation chemical kinetics mechanism.

$\Rightarrow$ A multilinear interpolation technique has been used for the implementation of the tabulation data matrix into the CFD code. The paper analyzed the influence of important operational parameters, stored in the lookup table, such as temperature, fuel concentration, and residence time, in the heat release and fuel consumption rates of SCF.

$\Rightarrow$ It was found that the increase of fuel concentration or residence time increases the heat release and "shifts" the entire negative temperature coefficient region toward lower temperatures.

$\Rightarrow$ The two-phase flow inside the stabilized cool flame reactor is simulated, utilizing the developed lookup table.

$\Rightarrow$ Predictions are presented for a variety of test cases and are compared to available experimental data, with satisfactory agreement.

$\Rightarrow$ Model validation tests indicate that prediction quality improves with 


\begin{tabular}{|c|c|c|c|c|c|}
\hline & & & & $\Rightarrow$ & $\begin{array}{l}\text { increasing values of air temperature } \\
\text { at the reactor's inlet. } \\
\text { The study demonstrated that the } \\
\text { combination of the lookup table } \\
\text { concept with a CFD code is an } \\
\text { effective, flexible, and low } \\
\text { computational cost approach that can } \\
\text { be directly implemented to support } \\
\text { the understanding of the complex } \\
\text { physical and thermo-chemical } \\
\text { phenomena occurring in SCF } \\
\text { reactors. }\end{array}$ \\
\hline $\begin{array}{l}15 \quad 200 \\
6\end{array}$ & $\begin{array}{l}\text { A small detailed } \text { M.V. Petrova, } \\
\text { chemical-kinetic } \\
\text { mechanism for } \\
\begin{array}{l}\text { hydrocarbon } \\
\text { combustion }\end{array}\end{array}$ & $\begin{array}{ll}\text { Combustion } & 14 \\
\text { and Flame } & 4\end{array}$ & $\begin{array}{l}526- \\
544\end{array}$ & $\begin{array}{l}\Rightarrow \\
\Rightarrow \\
\Rightarrow \\
\Rightarrow\end{array}$ & $\begin{array}{l}\text { This paper presents a chemical- } \\
\text { kinetic mechanism designed to be } \\
\text { used for autoignition, deflagrations, } \\
\text { detonations, and diffusion flames of } \\
\mathrm{C}_{3} \mathrm{H}_{4} \text {, propene, and propane. } \\
\text { To keep the mechanism small, } \\
\text { attention is restricted to pressures } \\
\text { below about } 100 \text { atm, temperatures } \\
\text { above about } 1000 \mathrm{~K} \text {, equivalence } \\
\text { ratios less than about } 3 \text { for the } \\
\text { premixed systems and strain rates } \\
\text { greater than about } 50 \mathrm{~s} \mathrm{~s}^{-1} \text { for } \\
\text { nonpremixed or partially premixed } \\
\text { systems. Thus soot formation and } \\
\text { low-temperature fuel-peroxide } \\
\text { chemistry was excluded. } \\
\text { Under these restrictions, hydrogen } \\
\text { combustion is included with } 21 \text { steps } \\
\text { among } 8 \text { chemical species, } \\
\text { combustion of carbon monoxide with }\end{array}$ \\
\hline
\end{tabular}


30 steps among 11 species, methane, methanol, ethane, ethylene, and acetylene combustion with 134 steps among 30 species, and propane, propene, allene, and propyne combustion with 177 steps among 37 species.

$\Rightarrow$ The mechanism has been extensively tested previously for all of these fuels except propane, propene, allene, and propyne. Tests are reported here for these last four fuels through comparisons with experiments and with predictions of other mechanisms for deflagration velocities and shocktube ignition.

$\Rightarrow$ To extend the mechanism to lower temperatures or to more fuel-rich low-strain conditions would involve adding many more species and reactions, and so the mechanism no longer would be classified as small and manageable. Thus investigators interested in studying conditions other then those addressed in the paper will have to resort to using much larger mechanisms available in the literature.

$\Rightarrow$ Therefore, it is advised to begin with the present mechanism and to introduce systematic reductions, through steady state and partialequilibrium approximations, for the 
purpose of obtaining much shorter reduced-chemistry descriptions that can be used in applications such as CFD analysis.

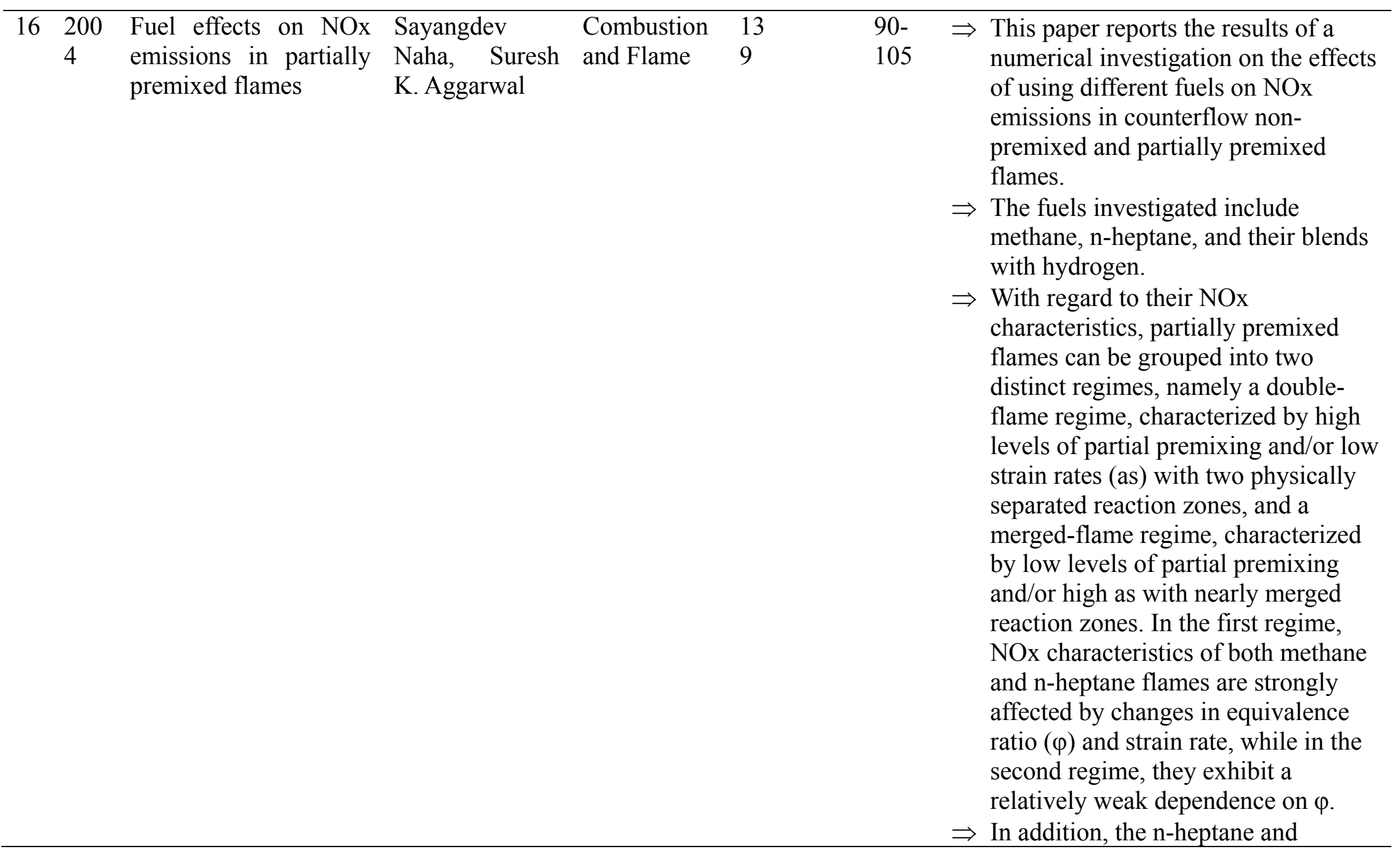


methane flames established under identical conditions exhibit widely different NOx emission behavior in the first regime but qualitatively similar behavior in the second regime.

$\Rightarrow$ Major differences include (i) significantly higher NO level and NOx emission index, (ii) much wider double-flame regime with regard to $\varphi$ (iii) dominance of the prompt mechanism over the thermal mechanism in the entire partially premixed regime, and (iv) noticeable reduction in NOx emission with hydrogen addition for $n$-heptane flames compared to methane flames.

$\Rightarrow$ These differences are attributable to the different fuel pyrolysis/oxidation chemistry of the two fuels, as the consumption of $\mathrm{n}$-heptane occurs mainly through the $\mathrm{C}_{2}$ path, while that of methane occurs mainly through the $\mathrm{C}_{1}$ path. As a result, the amounts of $\mathrm{C}_{2} \mathrm{H}_{2}$ and, consequently, of $\mathrm{CH}$ radicals formed in n-heptane flames are significantly higher than those in methane flames and are responsible for the observed differences in NOx characteristics of the two fuels.

$\Rightarrow$ Addition of hydrogen can significantly reduce NOx emission in 
n-heptane flames but has a negligible effect on NOx emission in methane flames. This is due to the fact that most of the NO in n-heptane flames is produced through the prompt mechanism, and the prompt $\mathrm{NO}$ is significantly reduced by $\mathrm{H}_{2}$, since the $\mathrm{C}_{2} \mathrm{H}_{2}$ and, consequently, the $\mathrm{CH}$ concentrations are reduced due to $\mathrm{H}_{2}$ addition. In contrast, for methane flames, the decrease in the prompt NO due to hydrogen addition is balanced by the corresponding increase in the thermal NO, and the total NO is essentially unaffected by hydrogen addition.

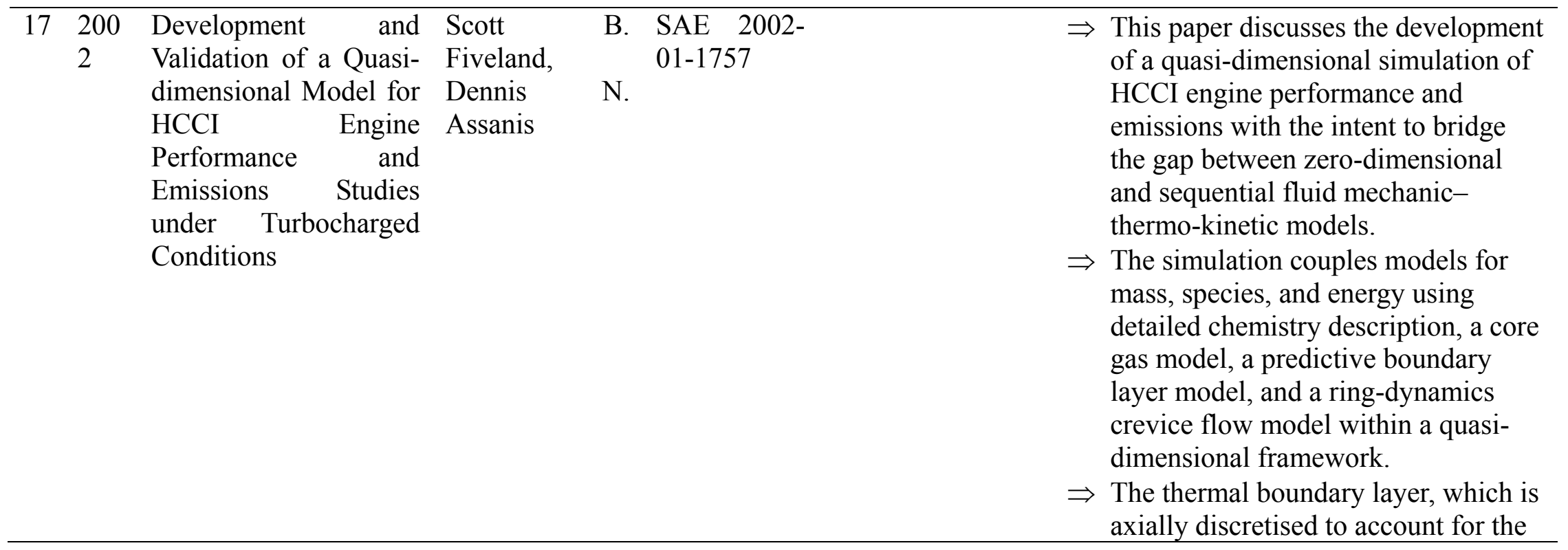


relative piston motion, is modeled

using compressible energy

arguments. The ring-pack crevice

zone is modeled using a coupled ring

dynamic and flow model.

$\Rightarrow$ The physically-based mathematical model is solved within the context of a single simulation framework, which lends to flexibility and expediency in performing a range of parametric studies.

$\Rightarrow$ The simulation was validated under turbo-charged conditions using data obtained from a Caterpillar 3500 test engine.

$\Rightarrow$ Predictions of engine combustion and performance were found to be in very satisfactory agreement with experimental data. It was also shown that the simulation can predict emissions of unburned hydrocarbons (UHC) within 10-20\% and carbon monoxides (CO) within $50 \%$ over a range of turbocharged engine conditions.

\begin{tabular}{llllll}
\hline 18200 & A $\quad$ Four-Stroke & Scott & B. & SAE 2000- \\
0 & Homogeneous Charge & Fiveland & & $01-0332$ \\
& Compression Ignition Dennis & N. & \\
& Engine Simulation for & Assanis & & \\
& Combustion and & & & \\
& Performance Studies & &
\end{tabular}
$\Rightarrow$ This study demonstrates the importance of coupling detailed chemistry descriptions with physical models of the HCCI engine processes.
$\Rightarrow$ The objective of this work is to develop a full cycle simulation model


of the HCCI engine that would integrate complex chemistry with physical models of the in-cylinder processes.

$\Rightarrow$ The simulation couples models for mass, species, and energy within a zero-dimensional framework.

$\Rightarrow$ The CHEMKIN libraries have been used to formulate a stiff chemical kinetic solver suitable for integration within a complete engine cycle simulation, featuring models of gas exchange, turbulence and wall heat transfer.

$\Rightarrow$ For illustration, two chemical kinetics schemes describing hydrogen and natural gas chemistry have been implemented in the code. The hydrogen scheme is a reduced one, consisting of 11 species and 23 reactions. The natural gas chemistry is described via the GRI mechanism 3.0 that considers 53 species and 325 reactions, including NOx chemistry.

$\Rightarrow$ It has been demonstrated that predicting heat transfer losses based on velocity and length scales that are physically connected to in-cylinder processes (gas exchange, mean flow, turbulence, piston motion) are substantially different than those based on the empirical, Woschni heat 
transfer correlation. Computations are first carried out in a variable volume bomb to demonstrate variations in ignition with temperature, pressure, equivalence ratio, and composition.

$\Rightarrow$ It was also concluded that HCCI operation with natural gas needs high compression ratios to promote ignition with reduced intake temperatures.

$\Rightarrow$ Subsequently, the complete cycle simulation is exercised to demonstrate the variation in output parameters to charge inlet temperature and effective compression ratio.

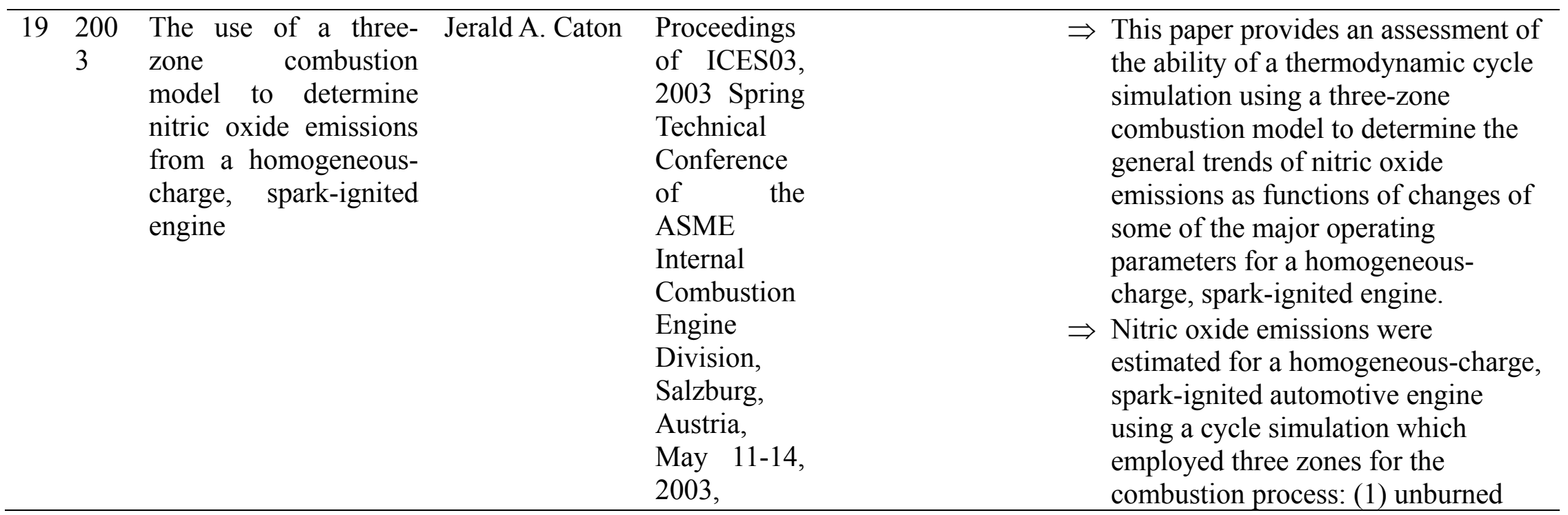


ICES2003-

598 gas, (2) adiabatic core region, and (3)

boundary-layer gas.

$\Rightarrow$ The computed nitric oxide computations were modestly dependent on the values of the combustion duration and the ignition delay.

$\Rightarrow$ From both the measurements and the computations, maximum nitric oxide concentrations were found for an equivalence ratio of about 0.9 . For leaner or richer equivalence ratios, the nitric oxide concentration decreased.

$\Rightarrow$ As ignition timing was advanced (i.e., the start of combustion occurred earlier in the cycle), the nitric oxide concentrations increased as determined from both the measurements and the computations.

$\Rightarrow$ Both the measurements and the computations indicated that the nitric oxide concentrations increased for higher inlet manifold pressures. The worst agreement was for the lowest manifold pressure, perhaps due to differences in the ignition delay and combustion duration (which were constant in the computations).

$\Rightarrow$ For lean equivalence ratios less than 0.9 , the nitric oxide concentrations decreased for increasing engine speed for both the measurements and the 
computations.

$\Rightarrow$ For equivalence ratios greater than 1.0 , the nitric oxide concentrations increased slightly with increasing engine speed for both the measurements and the computations.

$\Rightarrow$ The results for an equivalence ratio of 0.9 and 1.0 were examined in detail. For the case of equivalence ratio of 0.9 , the decreasing available time as engine speed increases dominates the increase of gas temperature. For the case of an equivalence ratio of 1.0 , however, the higher temperatures dominate the decreasing available time as engine speed increases.

$\Rightarrow$ In general, then, the computational procedures outlined in this work are sufficient to capture the major trends of nitric oxide concentrations as functions of engine operating parameters.

\begin{tabular}{lllrl}
\hline 20200 & A Real Time NOx & Magnus & SAE 2006- \\
6 & Model & for & Andersson, & $01-0195$ \\
& Conventional and & Bengt & \\
& Partially Premixed & Johansson, \\
& Diesel Combustion & Anders & \\
& & Hultqvist & \\
& & & Christof Nöhre
\end{tabular}

$\Rightarrow$ In this paper a fast NOx model is presented which can be used for engine optimization, after-treatment control or virtual mapping. High calculation speed is obtained by using table interpolation to calculate equilibrium temperatures and species concentrations. This is possible as the local equilibrium state only depends 
on pressure, temperature and

equivalence ratio.

$\Rightarrow$ The best model-out results are achieved if using a characteristic mixing time for the mixing of unburned cylinder air into the burned zones of approximately 180 CADs. This mixing time yields considerably better results than if assuming that there is no such mixing at all.

$\Rightarrow$ The model produces fairly accurate results at a high speed of calculation. For good accuracy, approximately 50 NOx formation zones are required which gives a calculation time of one second per engine cycle when running un-compiled Matlab code on a $2.8 \mathrm{GHz}$ PC.

$\Rightarrow$ Test data from a single cylinder engine and from a complete sixcylinder engine have been used for calibration and validation of the model.

$\Rightarrow$ Different compression ratios, EGR rates, injection timing, inlet pressures etc. were used in the validation tests.

$\Rightarrow$ The model calculates thermal (hightemperature) NOx formation by the two reactions of the original Zeldovich mechanism but by using a simple empirical compensation algorithm, the model can also be used for low-temperature NOx formation 
associated with high EGR rates and

long ignition delay.

$\Rightarrow$ If the engine is not fitted with a

cylinder pressure transducer, the model must be supplemented with a module that predicts the cylinder pressure trace from fuel injection data such as timing, duration and injected mass.

$\Rightarrow$ As the present model is based on single injections only, it would probably need modifications before being applied on multiple-injection strategies, especially if there is a long time period between the first and the last injection.

\begin{tabular}{|c|c|c|c|c|c|}
\hline 21 & $\begin{array}{l}200 \\
4\end{array}$ & $\begin{array}{l}\text { The 3-D CFD } \\
\text { Modeling Combined } \\
\text { with Detailed } \\
\text { Chemistry for Diesel } \\
\text { Spray Combustion }\end{array}$ & $\begin{array}{l}\text { Yutaka Murata, } \\
\text { Jin Kusaka } \\
\text { Yasuhiro } \\
\text { Daisho }\end{array}$ & $\begin{array}{l}\text { COMODIA } \\
2004 \text { - The } \\
\text { Sixth } \\
\text { International } \\
\text { Symposium } \\
\text { on } \\
\text { Diagnostics } \\
\text { and } \\
\text { Modeling of } \\
\text { Combustion } \\
\text { in Internal } \\
\text { Combustion } \\
\text { Engines, } \\
2004\end{array}$ & $\begin{array}{l}\Rightarrow \text { In the present study, the KIVA3V } \\
\text { rel.2 code, developed by the Los } \\
\text { Alamos National Laboratory was } \\
\text { utilized by modifying its spray and } \\
\text { combustion sub-models to make } \\
\text { them more predictive. A fuel spray } \\
\text { breakup model is developed based on } \\
\text { the Rayleigh-Taylor instability theory } \\
\text { combined with the conventional } \\
\text { model. } \\
\Rightarrow \text { The model can simulate the } \\
\text { formation process of evaporative } \\
\text { non-combustion sprays observed in a } \\
\text { constant volume chamber under high } \\
\text { temperature and pressure conditions. } \\
\text { The sub-model based on the Partially }\end{array}$ \\
\hline
\end{tabular}


Stirred Reactor (PaSR) is also used to represent the interaction between turbulent mixing and detailed gas phase chemical kinetics.

$\Rightarrow$ Using this model, the computational time needed for three-dimensional spray combustion analyses can be shortened, making it possible to conduct computations on a PC with single CPU. These sub-models are then improved and validated by comparing with experimental results.

$\Rightarrow$ The modified combustion model has been validated in comparison to not only visualized evaporative diesel sprays but also engine test results. It is indicated that the model can predict diesel spray dynamics and combustion.

$\Rightarrow$ The model can numerically visualize the processes of the low-temperature oxidation reactions followed by the hot-flame reactions in the spray combustion. It can also qualitatively predict soot and $\mathrm{NO}$ emissions in combination with soot and NO formation models. 


\begin{tabular}{|c|c|c|c|c|c|c|}
\hline 22 & $\begin{array}{l}200 \\
6\end{array}$ & $\begin{array}{l}\text { Multidimensional } \\
\text { Modeling of Advanced } \\
\text { Diesel Combustion } \\
\text { System by Parallel } \\
\text { Chemistry }\end{array}$ & $\begin{array}{l}\text { P. Belardini, } \\
\text { C. Bertoli, } \\
\text { S. Corsaro } \\
\text { P. D' Ambra }\end{array}$ & $\begin{array}{l}\text { SAE 2006- } \\
01-0201\end{array}$ & $\begin{array}{l}\Rightarrow \\
\Rightarrow \\
\Rightarrow \\
\Rightarrow\end{array}$ & $\begin{array}{l}\text { The present paper deals with the } \\
\text { experimental and numerical } \\
\text { investigation of the combustion } \\
\text { process in a modern second } \\
\text { generation Common Rail Diesel } \\
\text { engine for light duty application. } \\
\text { To model the combustion process, a } \\
\text { detailed kinetic scheme involving } 57 \\
\text { species and } 290 \text { equations, based on } \\
\text { the n-heptane combustion, was used, } \\
\text { interfacing the KIVA-3V code with } \\
\text { the CHEMKIN-II chemistry package. } \\
\text { The computational efficiency of the } \\
\text { KIVA-3V Release } 2 \text { code has been } \\
\text { significantly improved with the use } \\
\text { of parallel techniques for chemistry, } \\
\text { jointly with the adaptive choice of the } \\
\text { integration method and of the local } \\
\text { time steps. The gain obtained in } \\
\text { terms of computational time may } \\
\text { therefore be spent for more detailed } \\
\text { kinetics, expressed not only in the } \\
\text { Arrhenius form, and able to model in } \\
\text { the whole the low and the high } \\
\text { temperature oxidation process, as } \\
\text { necessary for the new generation of } \\
\text { combustion engines. } \\
\text { Due to the spatial in-homogeneous } \\
\text { characteristics of diesel combustion, } \\
\text { the grid partitioning is a key point for } \\
\text { efficient computation. Therefore, } \\
\text { different grid partitioning criteria } \\
\text { were used and analyzed. }\end{array}$ \\
\hline
\end{tabular}


$\Rightarrow$ The performance analysis suggests that a random partitioning criterion is useful to smooth the grid inhomogeneities over the processes.

$\Rightarrow$ The chemical combustion model permits the easy change of the chemistry using and testing more and more sophisticated kinetics. The kinetic part of the program is conceptually separated from the numerical solvers: therefore it is possible to separately evaluate the quality of the kinetics and the quality of the numerical solutions.

\begin{tabular}{llrll}
\hline 23200 & Modelling & Diesel & Claes Ericson, & SAE 2006- \\
6 & Engine Combustion & Björn & $01-0687$ \\
& and NOx Formation & Westerberg, \\
& for Model Based Magnus \\
& Control and Andersson, \\
& Simulation of Engine Rolf Egnell \\
& and $\quad$ Exhaust \\
& Aftertreatment \\
& Systems
\end{tabular}

$\Rightarrow$ This paper is focused on the calculation of engine-out NOx and engine parameters such as cylinder pressure, temperature and gas flows.

$\Rightarrow$ A quasi steady gas exchange model (including models for EGR and VGT) is combined with a two-zone zero dimensional combustion model.

$\Rightarrow$ The model uses fuel flow parameters to generate heat release data and calculates the corresponding pressure trace. Flow and efficiency maps are used to calculate compressor and turbine flows.

$\Rightarrow$ The temperature and equilibrium concentrations in the zones are calculated by the simplified combustion model and the corresponding NOx concentration is 
given by the original Zeldovich mechanism.

$\Rightarrow$ By combining the combustion and gas exchange models the result is a low complexity complete engine model. The agreement between measured and simulated NOx is satisfactory. This is possibly related to an error in the EGR rate estimation.

$\Rightarrow$ Compared to earlier models, the presented model is considerably faster. The computational time can be improved using longer step lengths in the NO calculation and likely further by using more efficient and compiled code.

$\Rightarrow$ The model is appropriate to use for simulation of complete engine and SCR systems and in a simplified form for model based control.

\begin{tabular}{lllll}
\hline 24200 & Development $\quad$ of & A. Albrecht, & SAE 2006- \\
6 & Highly Premixed & J. Chauvin, & $01-1072$ \\
& Combustion Diesel & F. A. Lafossas, \\
& Engine Model: From & S. Potteau, \\
& Simulation to Control & G. Corde \\
& Design
\end{tabular}


$\Rightarrow$ Transient tests were also conducted showing the validity and the relevancy of such a simulator for control purpose.

$\Rightarrow$ The simulator is then used to design an individual cylinder AFR estimator. It reconstructs the AFR of each cylinder from a measurement made by a single sensor located downstream the turbine.

$\Rightarrow$ The availability of such an estimator giving reliable information can lead to improvements on new generation of Diesel engines which have to deal with high EGR rate.

$\Rightarrow$ By the closed-loop control of the masses of fuel, all cylinders are "well-balanced", it means that the injection timing, mostly start of injection, SOI, is adapted for each cylinder, producing each one same noise, and pollutant emissions.

\begin{tabular}{lllll}
\hline 25200 & A & Modeling & Kushal & SAE 2006- \\
6 & Investigation & of & Narayanaswam & $01-1084$ \\
& Combustion Control & y, & \\
& Variables During DI- Christopher J. \\
& Diesel HCCI Engine & Rutland & \\
& Transients
\end{tabular}

$\Rightarrow$ A comprehensive system level modeling approach is used to understand the effects of the various physical actuators during diesel HCCI transients. Control concepts during transient operations are simulated using a set of actuators suitable for combustion control in diesel HCCI engines (intake valve actuation, injection timing, cooled 
EGR, intake boost pressure and droplet size).

$\Rightarrow$ The impact of these actuating techniques on the overall engine performance is quantified by investigating the amount of actuation required, timing of actuation and the use of a combination of actuators.

$\Rightarrow$ Combined actuation improved actuation space that can be used to phase combustion timing better and in extending the operating range. The results from transient simulations indicate that diesel HCCI operation would benefit from the combined actuation of intake valve closure, injection timing, boost and cooled EGR.

$\Rightarrow$ While IVC actuation and cooled EGR provide ways to improve combustion phasing, variations in intake boost pressure and injection timing help to reduce wall wetting, improve fuel economy, increase homogeneity and maintain combustion stability.

$\Rightarrow$ An example of a mode transition between conventional diesel and HCCI combustion regimes is also demonstrated by altering the charge preparation (spray characteristics) and using a combination of control variables. 
$\Rightarrow$ The study shows that diesel-HCCIdiesel mode transitions can be achieved with minimal effects from cycle-to-cycle coupling by trapping the least amount of hot residuals from previous engine cycles.

$\Rightarrow$ The impact of different physical actuators was quantified by investigating the effect of each control variable on IVC actuation. It was observed that combined IVC/SOI actuation was more effective than using IVC actuation only. The addition of cooled EGR allowed for the available IVC actuation range to improve combustion phasing.

$\Rightarrow$ Although the operating conditions chosen in this study are not desirable from an engine performance perspective, the intention of the authors was to understand the behavior of different actuators during HCCI transients.

$\Rightarrow$ Future work from the authors will focus on combined use of these actuating techniques towards optimizing the engine performance in different combustion regimes. 


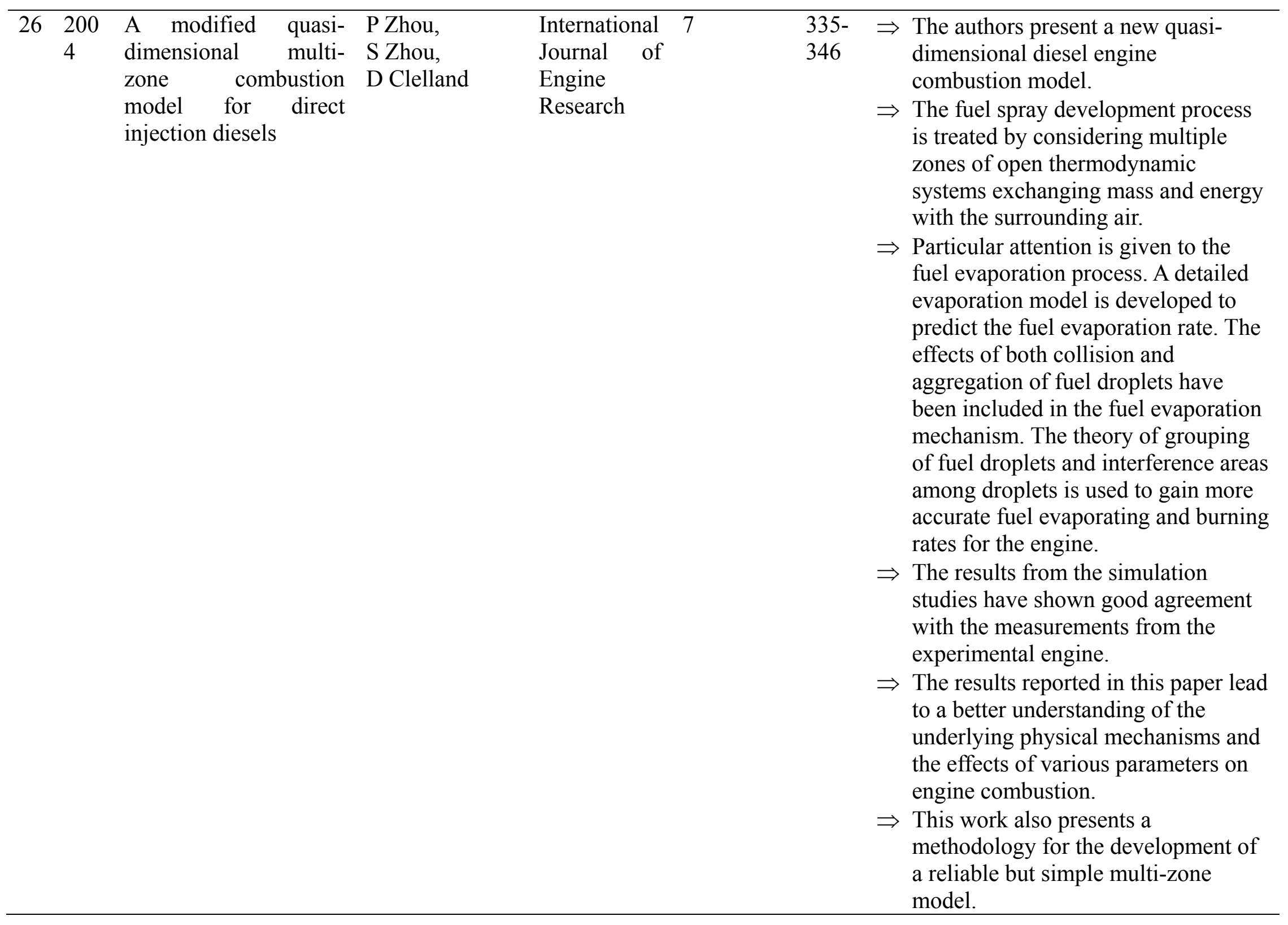




\begin{tabular}{|c|c|c|c|c|c|c|c|}
\hline 27 & $\begin{array}{l}198 \\
0\end{array}$ & $\begin{array}{l}\text { The applications of a } \\
\text { hydrocarbon } \\
\text { autoignition model in } \\
\text { simulating knock and } \\
\text { other engine } \\
\text { combustion } \\
\text { phenomena }\end{array}$ & $\begin{array}{l}\text { S. L. Hirst, } \\
\text { L. J. Kirsch }\end{array}$ & $\begin{array}{l}\text { Combustion } \\
\text { modeling in } \\
\text { reciprocatin } \\
\text { g engines } \\
\text { ed. C.A. } \\
\text { Amman \& J. } \\
\text { Mattavi, } \\
1980, \\
\text { Plenum } \\
\text { Press, NY }\end{array}$ & $\begin{array}{l}193- \\
229\end{array}$ & $\begin{array}{l}\Rightarrow \\
\Rightarrow \\
\Rightarrow \\
\Rightarrow \\
\Rightarrow \\
\Rightarrow\end{array}$ & $\begin{array}{l}\text { The paper demonstrates a chemical } \\
\text { model and its optimization to obtain } \\
\text { quantitative predictions of the } \\
\text { ignition characteristics of } \\
\text { hydrocarbon fuels. } \\
\text { The ignition model employs generic } \\
\text { species in a global eight-step chain- } \\
\text { branching reaction mechanism of } \\
\text { hydrocarbon ignition and includes } \\
\text { reactions for chain initiation, } \\
\text { propagation, branching, and } \\
\text { termination } \\
\text { The propagation path includes } \\
\text { chemical heat release corresponding } \\
\text { to the consumption of one }-\mathrm{CH} 2 \\
\text { group from the original fuel molecule } \\
\text { The overall stoichiometry is } \\
\text { approximated by assuming a constant } \\
\text { CO-CO } 2 \text { ratio }(\mathrm{CO} / \mathrm{CO} 2=\lambda /(1-\lambda) \\
\text { where } \lambda=0.67) \text { for the complete } \\
\text { combustion process, and constant } \\
\text { oxygen consumption (p moles per } \\
\text { cycle where } \mathrm{p}=[\mathrm{n}(2-\lambda)+\mathrm{m}] / 2 \mathrm{~m} \text {; } \mathrm{m} \\
\text { and } \mathrm{n} \text { are empirical constants) } \\
\text { The model is proposed as a } \\
\text { development tool to model knock in } \\
\text { the end gas of gasoline engines. }\end{array}$ \\
\hline 28 & $\begin{array}{l}198 \\
0\end{array}$ & $\begin{array}{l}\text { Modeling of engine } \\
\text { exhaust emissions - } \\
\text { An introductory } \\
\text { overview }\end{array}$ & H. K. Newhall, & $\begin{array}{l}\text { Combustion } \\
\text { modeling in } \\
\text { reciprocatin } \\
\text { g engines } \\
\text { ed. C.A. }\end{array}$ & $\begin{array}{l}331- \\
343\end{array}$ & $\Rightarrow$ & $\begin{array}{l}\text { This paper provides an overview of } \\
\text { emissions modeling as applied to } \\
\text { internal combustion engines. Of } \\
\text { particular interest is modeling NOx } \\
\text { emissions using Zeldovich kinetics. }\end{array}$ \\
\hline
\end{tabular}




\begin{tabular}{|c|c|c|c|}
\hline & & $\begin{array}{l}\text { Amman \& J. } \\
\text { Mattavi, } \\
1980, \\
\text { Plenum } \\
\text { Press, NY }\end{array}$ & $\begin{array}{l}\Rightarrow \text { It is concluded that there is a strong } \\
\text { need for incorporating finite rate } \\
\text { chemistry models within the } \\
\text { framework of phenomenological } \\
\text { combustion models } \\
\Rightarrow \text { In closing, the author emphasizes the } \\
\text { need for extensive experiments to } \\
\text { obtain data to assist in the } \\
\text { development of emissions models } \\
\text { particularly to simulate the formation } \\
\text { and destruction of NOx and } \\
\text { particulate emissions. }\end{array}$ \\
\hline $\begin{array}{ll}29 & 198 \\
& 0\end{array}$ & $\begin{array}{l}\text { A model for the } \text { S. M. Shahed, } \\
\text { formation of emissions } \\
\text { P. F. Flynn, } \\
\text { in a direct-injection } \\
\text { W. T. Lyn } \\
\text { diesel engine }\end{array}$ & $\begin{array}{l}\text { Combustion } \\
\text { modeling in } \\
\text { reciprocatin } \\
\text { g engines } \\
\text { ed. C.A. } \\
\text { Amman \& J. } \\
\text { Mattavi, } \\
1980, \\
\text { Plenum } \\
\text { Press, NY }\end{array}$ & $\begin{aligned} & \Rightarrow \text { A mathematical model of diesel spray } \\
& \text { combustion in direct injected diesel } \\
& \text { engines is described } \\
& \Rightarrow \text { The model is based on } \\
& \text { phenomenological concepts. } \\
& \text { Combustion occurs in multiple } \\
& \text { thermodynamic zones, which are } \\
& \text { open systems that allow mass and } \\
& \text { energy exchange } \\
& \Rightarrow \text { The calculation of fuel-air mixing } \\
& \text { rates in the developing diesel spray is } \\
& \text { based on transient plume growth } \\
& \text { equations together with concentration } \\
& \text { profiles within the spray plume } \\
& \Rightarrow \text { The model allows parametric } \\
& \text { investigation of changing injection } \\
& \text { pressures on the nature of } \\
& \text { combustion in diesel engines. } \\
& \Rightarrow \text { Results from the quasi-dimensional } \\
& \text { phenomenological model confirm the }\end{aligned}$ \\
\hline
\end{tabular}




\begin{tabular}{|c|c|c|c|c|c|}
\hline 30 & $\begin{array}{l}200 \\
0\end{array}$ & $\begin{array}{l}\text { NO Formation and } \\
\text { Decomposition Models } \\
\text { for DI Diesel Engines }\end{array}$ & $\begin{array}{l}\text { W. L. Easley } \\
\text { A. M. Mellor } \\
\text { S. L. Plee }\end{array}$ & $\begin{array}{l}\text { SAE 2000- } \\
01-0582\end{array}$ & $\begin{aligned} & \Rightarrow \text { A two-zone DI Diesel flame model is } \\
& \text { used as the } \\
& \Rightarrow \text { foundation for a characteristic time } \\
& \text { analysis of NOx } \\
& \Rightarrow \text { emissions from DI Diesel engines. } \\
& \Rightarrow \text { Characteristic times for NO } \\
& \text { formation are defined using } \\
& \text { Zeldovich kinetics and nitrous oxide } \\
& \text { formation mechanisms } \\
& \Rightarrow \text { Both mechanisms are shown to be } \\
& \text { important for NO formation with } \\
& \text { Zeldovich faster at normal Diesel } \\
& \text { operating conditions and nitrous } \\
& \text { oxide becoming more important as } \\
& \text { Diesel flame temperatures are } \\
& \text { lowered by addition of diluents (EGR } \\
& \text { or water). }\end{aligned}$ \\
\hline 31 & $\begin{array}{l}200 \\
6\end{array}$ & $\begin{array}{l}\text { Measurement of the } \\
\text { Percentage of Bio- } \\
\text { Diesel in Blends with a } \\
\text { Commercial Dielectric } \\
\text { Fuel Sensor }\end{array}$ & $\begin{array}{l}\text { Carey Jenkins, } \\
\text { Daniel } \\
\text { Mastbergen, } \\
\text { Rudolf } \\
\text { Stanglmaier }\end{array}$ & $\begin{array}{l}\text { Proceedings } \\
\text { of } \\
\text { ICEF2006 } \\
\text { ASME } \\
\text { Internal } \\
\text { Combustion } \\
\text { Engine } \\
\text { Division } \\
2006 \quad \text { Fall } \\
\text { Technical }\end{array}$ & $\begin{array}{l}\Rightarrow \text { The objective of this study was to } \\
\text { evaluate a commercial fuel sensor as } \\
\text { a possible biodiesel percentage } \\
\text { sensor. The Ford flexible fuel sensor } \\
\text { used in this study was originally } \\
\text { designed to measure the amount of } \\
\text { ethanol in ethanol/gasoline blends. } \\
\Rightarrow \text { The Ford flexible fuel sensor was } \\
\text { able to consistently detect differences } \\
\text { in petroleum based diesel and }\end{array}$ \\
\hline
\end{tabular}




\begin{tabular}{|c|c|c|c|c|}
\hline & & $\begin{array}{l}\text { Conference } \\
\text { November } \\
5-8, \quad 2006, \\
\text { Sacramento, } \\
\text { California, } \\
\text { USA }\end{array}$ & $\begin{array}{l}\Rightarrow \\
\Rightarrow \\
\Rightarrow\end{array}$ & $\begin{array}{l}\text { soybean oil bio-diesel. } \\
\text { The Ford flexible fuel sensor was } \\
\text { capable of measuring the biodiesel } \\
\text { percentage to within about }+3 \% \text {, and } \\
\text { temperature changes between } 10 \text { and } \\
50{ }^{\circ} \mathrm{C} \text { produced no substantial change } \\
\text { in this measurement } \\
\text { Emissions and performance } \\
\text { measurements on a production diesel } \\
\text { engine suggest that this sensor } \\
\text { accuracy is adequate to provide } \\
\text { feedback to the engine ECU to make } \\
\text { dynamic adjustments to the engine } \\
\text { operation. }\end{array}$ \\
\hline $\begin{array}{l}32 \quad 200 \\
6\end{array}$ & 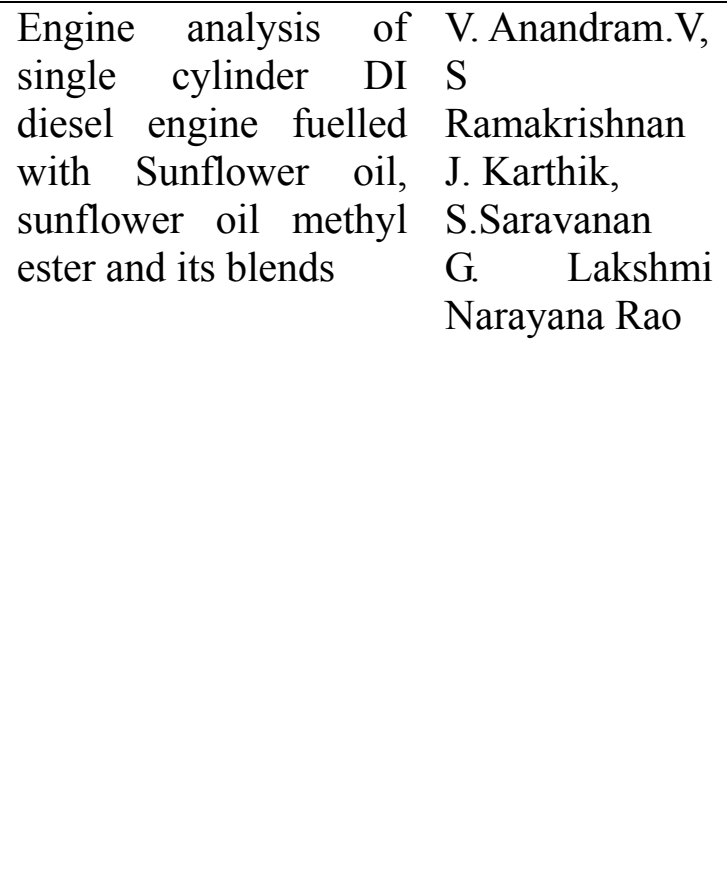 & 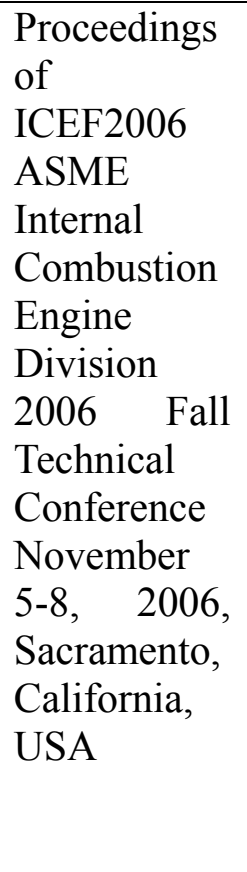 & $\begin{array}{l}\Rightarrow \\
\Rightarrow \\
\Rightarrow \\
\Rightarrow\end{array}$ & $\begin{array}{l}\text { The feasibility of sunflower oil as an } \\
\text { alternate fuel in a single cylinder } \\
\text { direct injection diesel engine is } \\
\text { evaluated. } \\
\text { The fuels tested were diesel, } \\
\text { sunflower oil (SFNE), Sunflower } \\
\text { methyl ester (SFME), SF40 ( } 40 \% \\
\text { blend of sunflower oil with diesel), } \\
\text { SM40 ( } 40 \% \text { blend of SFME with } \\
\text { diesel). } \\
\text { The brake thermal efficiency of } \\
\text { SFME and its blends were greater } \\
\text { than SFNE and its blends at most of } \\
\text { the loads. } \\
\text { Except for NOx emissions all other } \\
\text { emissions (HC, CO and soot } \\
\text { concentration) of SFME and its } \\
\text { blends were lower compared to }\end{array}$ \\
\hline
\end{tabular}


SFNE and its blends.

$\Rightarrow$ The ignition delays for the biofuels were found to be lower than that of diesel. The heat release rate for the biofuels was generally lower and occurred earlier to diesel.

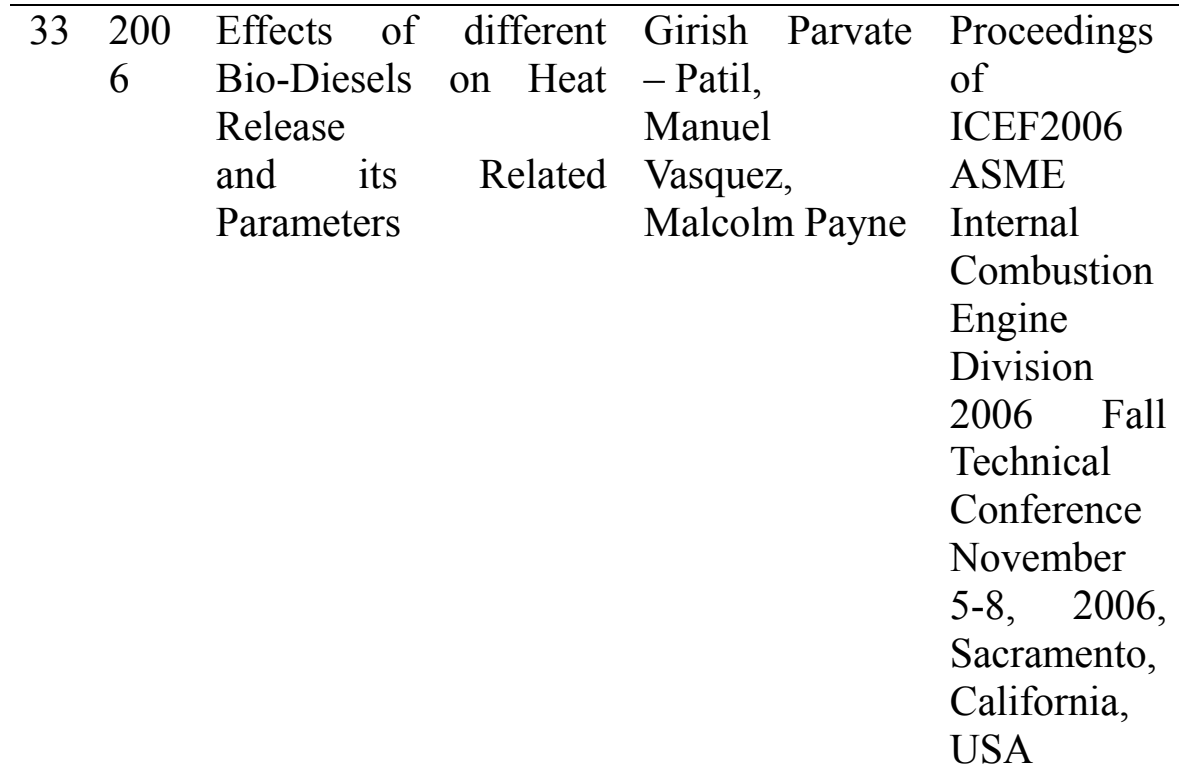

$\Rightarrow$ This paper evaluates the combustion resulting from straight diesel (\#2 diesel)and blends of biodiesel derived from canola (CB 20, CB 100) and frying oil (FB 20, FB 100)

$\Rightarrow$ A comparison of physical properties indicate that the density of biodiesel is higher than that of straight (\#2) diesel .fuel

$\Rightarrow$ The increased density of biodiesel is attributed to higher injection pressures. The peak fuel injection pressure is directly proportional to the density, hence, the bulk modulus of elasticity of fuel.

$\Rightarrow$ Higher bulk modulus of the fuel results in: higher fuel injection pressure, earlier injection, longer ignition delay (at same cetane number of both fuels), higher local and combustion temperatures resulting in NOx emissions. 


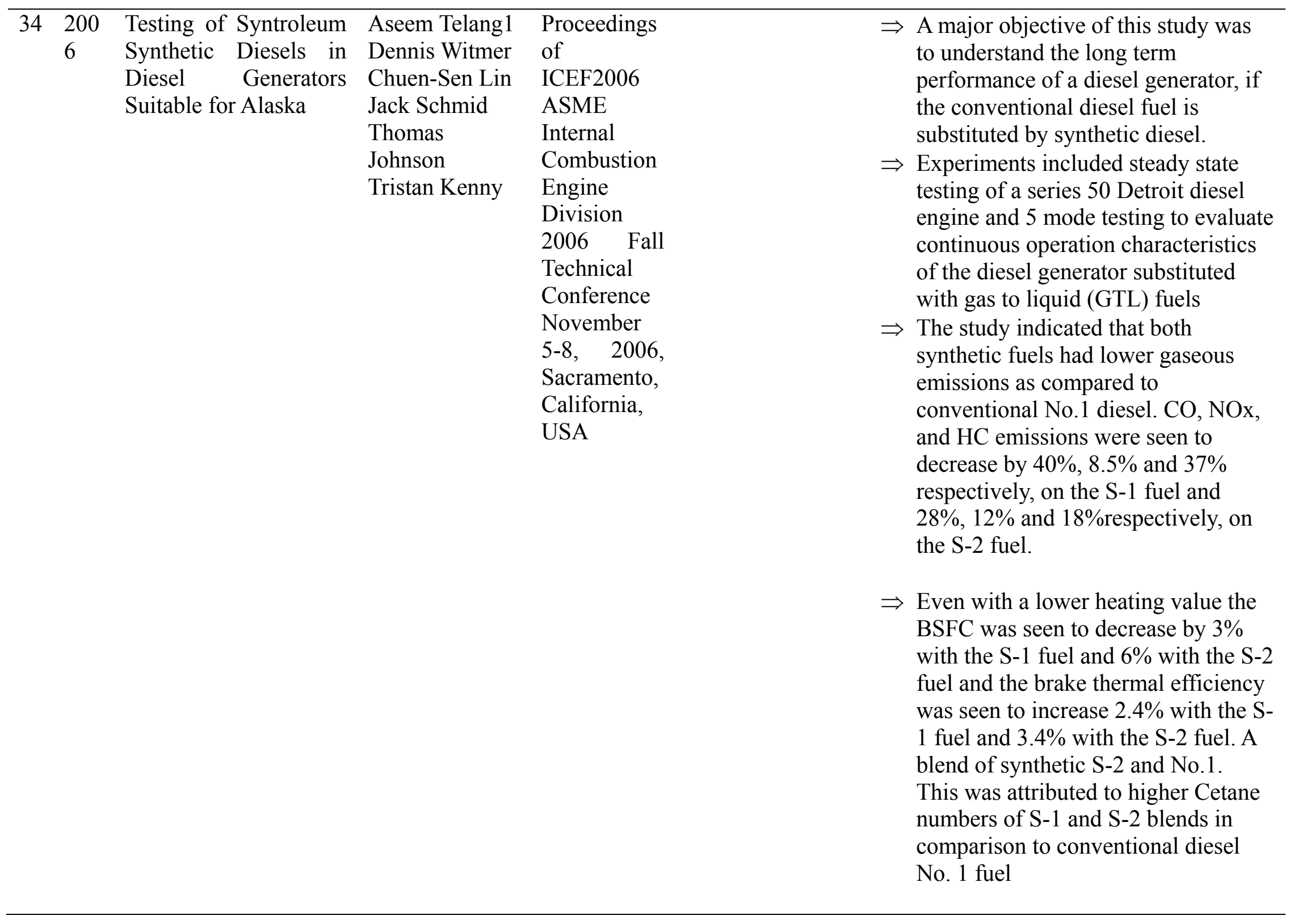




\begin{tabular}{|c|c|c|c|c|c|}
\hline $\begin{array}{ll}35 \quad 200 \\
\\
6\end{array}$ & $\begin{array}{l}\text { Ignition delay of bio- } \\
\text { ester fuel droplets }\end{array}$ & $\begin{array}{l}\text { Timothy } \\
\text { Vaughn, } \\
\text { Matthew } \\
\text { Hammill, } \\
\text { Michael Harris, } \\
\text { Anthony J. } \\
\text { Marchese }\end{array}$ & $\begin{array}{l}\text { SAE 2006- } \\
01-3302\end{array}$ & $\begin{array}{l}\Rightarrow \\
\Rightarrow \\
\Rightarrow \\
\Rightarrow \\
\Rightarrow\end{array}$ & $\begin{array}{l}\text { Literature suggests that NOx } \\
\text { emissions increase with bio diesel } \\
\text { fueling. The increase in NOx } \\
\text { emissions is attributed to variations } \\
\text { in physical and chemistry of } \\
\text { biodiesel. } \\
\text { This paper attempts to investigate the } \\
\text { droplet ignition delay characteristics } \\
\text { of biodiesel blends. In the present } \\
\text { study, droplet ignition delay } \\
\text { experiments were conducted using a } \\
\text { variety of methyl esters and the } \\
\text { results were compared to commercial } \\
\text { soy methyl ester biodiesel. } \\
\text { Specifically, fuel droplets were } \\
\text { injected into a tube furnace } \\
\text { containing atmospheric air at } \\
\text { temperatures up to } 1000 \mathrm{C} \text {. The } \\
\text { ignition event was characterized by } \\
\text { measurement of UV emission from } \\
\text { hydroxyl radical (OH*) } \\
\text { chemiluminescence. } \\
\text { The study concludes that Methyl } \\
\text { oleate (C19H36O2) exhibited similar } \\
\text { ignition delay times to the } \\
\text { commercial biodiesel for the entire } \\
\text { temperature range tested. } \\
\text { Based on droplet ignition delay, } \\
\text { methyl oleate has potential as a } \\
\text { surrogate fuel for biodiesel studies. }\end{array}$ \\
\hline
\end{tabular}




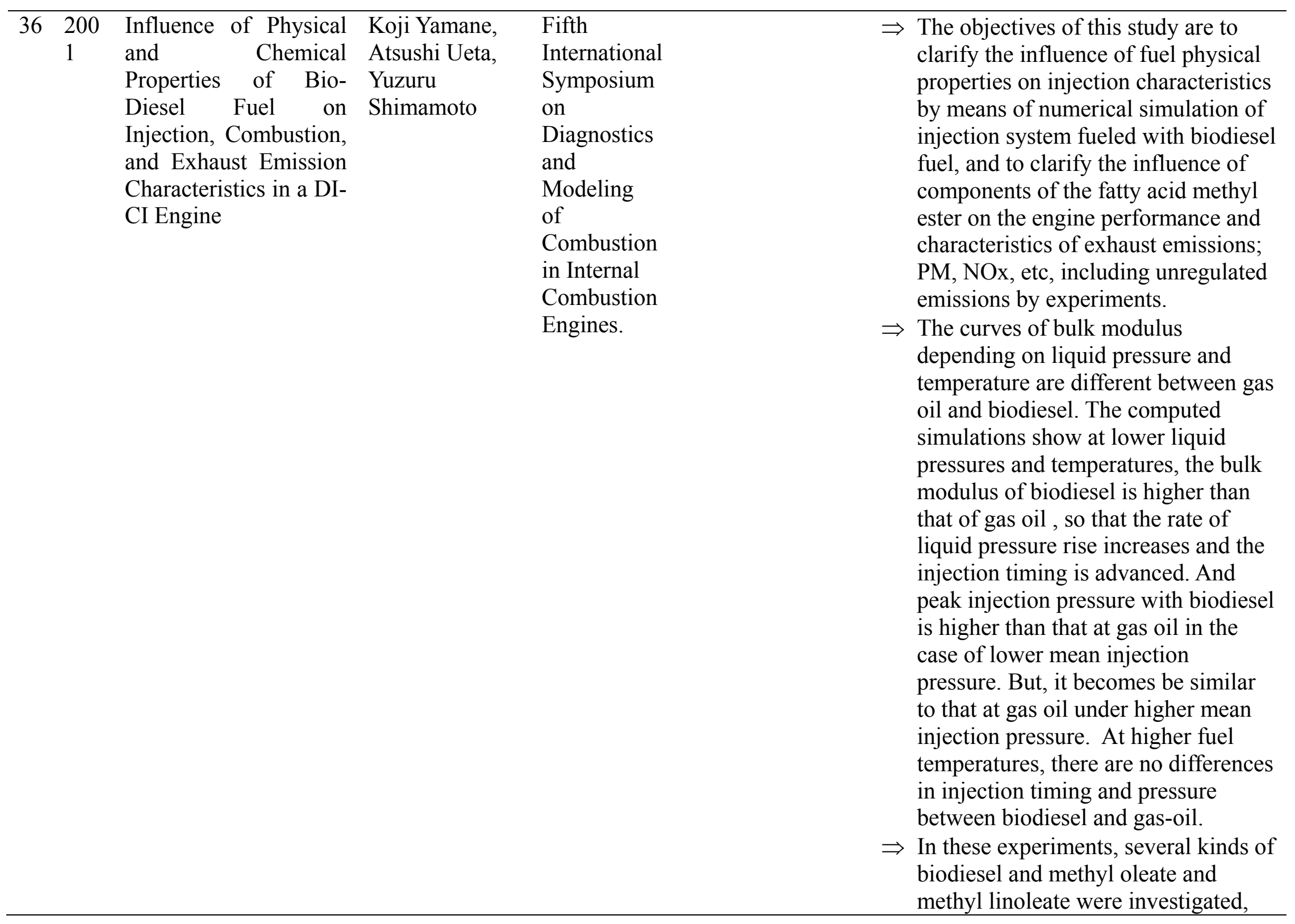


both of which are main chemical

components in biodiesel

$\Rightarrow$ The major conclusion of this study is that physical properties of Bio-Diesel had little effect on ignition timing and pressure at high temperatures, but significant effects occur at low temperatures.

37199 Blending Rules for L. $6 \quad$ Formulating Diesel Fuel

\author{
Bio- Clements
}

Davis

Davis

and

Products

from

Renewable

Resources-

Proceedings

of the Third

Liquid Fuel

Conference,

Nashville,

TN
$44-\Rightarrow$ This paper presents a simple method 53 to evaluate biodiesel properties like density, viscosity, cetane number, heating value and cloud point apriori.

$\Rightarrow$ The density of fatty acids are estimated using an established relation that is linearly dependent on temperature and a simple linear mixing rule is proposed to estimate the density of mixtures of fatty acid methyl esters

$\Rightarrow$ The estimation of viscosities has been proposed using equations that are exponential relations, and it is stated that the estimation of viscosity has the maximum amount of uncertainty.

$\Rightarrow$ The cetane number and heating values of mixtures is estimated using a simple mixing equation where in the cetane number or heating values of the mixture is a mass weighted average

$\Rightarrow$ The cloud point estimation is 


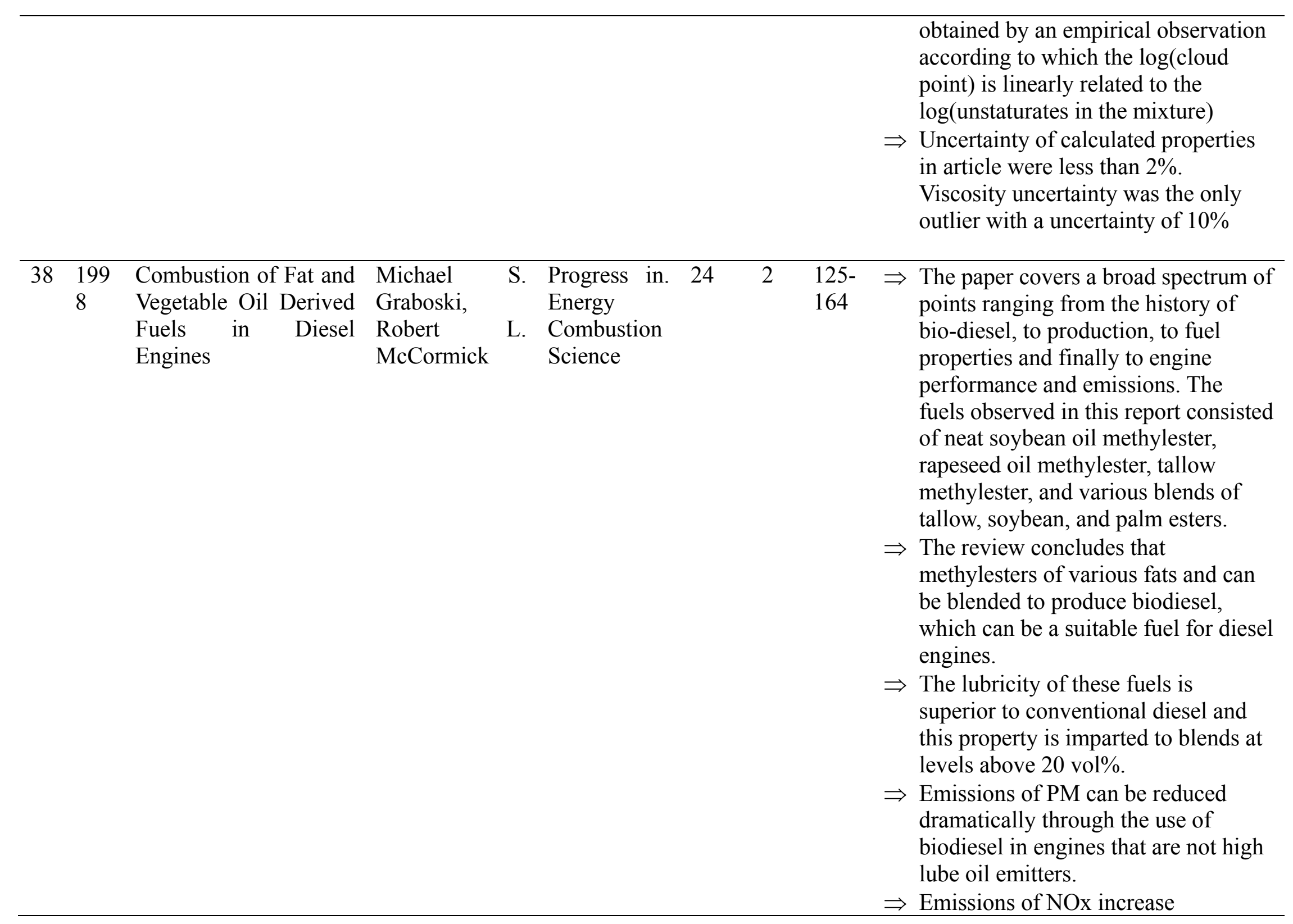


significantly for both neat and blended fuels in both two- and fourstroke engines, The increase may be lower in newer, lower NOx emitting four-strokes, but additional data are need to confirm this conclusion.

$\Rightarrow$ Methylesters of various fats and oils are suitable fuels for diesel engines. Bio-diesel in neat or blended form has no effect on the BTU based engine fuel economy.

$\Rightarrow$ The economic viability of feed stock derived bio fuels is dependent on feed stock costs; however, lower cost waste oils may be more economically attractive.

39200 Predicting the Physical W. Yuan, 3 Properties of Bio- A.C. Hansen, Diesel for Combustion Q. Zhang Modeling

American
Society of
Agricultural
Engineers

46

46

$\begin{array}{ll}1487 & \Rightarrow \\ - & \end{array}$

$\Rightarrow$ This article presents established methods and numerical equations to predict the physical properties of biodiesel blends.

$\Rightarrow$ Physical properties estimated include vapor pressure, latent heat of vaporization, liquid density, surface tension and viscosity

$\Rightarrow$ The equations employed in estimating the physical properties were integrated into the KIVA code used for multidimensional combustion simulations 


\begin{tabular}{|c|c|c|c|c|c|c|c|c|c|}
\hline 40 & $\begin{array}{l}200 \\
6\end{array}$ & $\begin{array}{l}\text { PAH emissions and } \\
\text { energy efficiency of } \\
\text { palm-biodiesel blends } \\
\text { fueled on diesel } \\
\text { generator }\end{array}$ & $\begin{array}{l}\text { Yuan-Chung } \\
\text { Lin, } \\
\text { Wen-Jhy Lee, } \\
\text { Hsia-Chung } \\
\text { Hou }\end{array}$ & $\begin{array}{l}\text { Atmospheric } \\
\text { Environmen } \\
\mathrm{t}\end{array}$ & 40 & 21 & $\begin{array}{l}3930 \\
- \\
3940\end{array}$ & $\begin{array}{l}\Rightarrow \\
\Rightarrow \\
\Rightarrow \\
\Rightarrow \\
\Rightarrow\end{array}$ & $\begin{array}{l}\text { This paper investigates the effect of } \\
\text { palm oil addition to diesel fuel in } \\
\text { reducing ploy aromatic hydrocarbons } \\
\text { (PAH), which are soot precursors. } \\
\text { It is found that with increasing palm } \\
\text { oil substitution, PM emissions } \\
\text { decrease substantially. } \\
\text { The brake specific fuel consumption } \\
\text { (BSFC) was however observed to } \\
\text { increase with increasing palm oil } \\
\text { substitution. } \\
\text { The results of this study indicated } \\
\text { that palm-biodiesel can improve } \\
\text { combustion efficiency in diesel } \\
\text { engines, but adding too much palm- } \\
\text { biodiesel fraction to Premium Diesel } \\
\text { Fuel results in incomplete } \\
\text { combustion and decelerated net } \\
\text { combustion rates } \\
\text { The study also indicated that the } \\
\text { diesel engine required considerable } \\
\text { modification to accommodate higher } \\
\text { fractions of biodiesel. }\end{array}$ \\
\hline 41 & $\begin{array}{l}200 \\
5\end{array}$ & $\begin{array}{l}\text { Kinematic viscosity of } \\
\text { biodiesel fuel } \\
\text { components and } \\
\text { related } \\
\text { compounds. Influence } \\
\text { of compound structure } \\
\text { and comparison to } \\
\text { petrodiesel fuel } \\
\text { components }\end{array}$ & $\begin{array}{l}\text { Knothe, G } \\
\text { Steidley, K }\end{array}$ & Fuel & 84 & 9 & $\begin{array}{l}1059 \\
- \\
1065\end{array}$ & $\begin{array}{l}\Rightarrow \\
\Rightarrow \\
\end{array}$ & $\begin{array}{l}\text { Kinematic viscosities of fatty acid } \\
\text { methyl esters were determined in this } \\
\text { study and it is reported that the } \\
\text { kinematic viscosity of fatty } \\
\text { compounds is significantly } \\
\text { influenced by compound structure } \\
\text { Influencing factors are chain length, } \\
\text { position, number, and nature of } \\
\text { double bonds, as well as nature of }\end{array}$ \\
\hline
\end{tabular}


oxygenated groups

$\Rightarrow$ It is concluded that the viscosity range of fatty compounds is greater than that of various hydrocarbons comprising petrodiesel.

$\Rightarrow$ It is speculated that the viscosity of the fatty acids comprising a certain feedstock may affect the utility of the resulting esters as biodiesel fuel.

\begin{tabular}{|c|c|c|c|c|c|c|c|}
\hline 42 & $\begin{array}{l}200 \\
4\end{array}$ & $\begin{array}{l}\text { Biodiesel as alternative } \\
\text { fuel: Experimental } \\
\text { analysis and energetic } \\
\text { evaluations }\end{array}$ & $\begin{array}{l}\text { Carraretto, C } \\
\text { Macor, A } \\
\text { Mirandola, A } \\
\text { Stoppato, A } \\
\text { Tonon, S }\end{array}$ & Energy & 29 & $\begin{array}{l}2195 \\
- \\
2211\end{array}$ & $\begin{aligned} & \Rightarrow \text { This paper investigates the viability } \\
& \text { of biodiesel as a potential future fuel. } \\
& \Rightarrow \text { The authors discuss some major } \\
& \text { concerns of biodiesel including } \\
& \text { oxidation problems and reduction of } \\
& \text { storage life of tanks, formation of } \\
& \text { residues, incompatibility with plastics } \\
& \text { used to make gaskets etc. } \\
& \Rightarrow \text { Despite the issues arising from varied } \\
& \text { physical properties biodiesel presents } \\
& \text { an environmentally friendly and } \\
& \text { economic alternative to diesel }\end{aligned}$ \\
\hline 43 & $\begin{array}{l}200 \\
5\end{array}$ & $\begin{array}{lr}\text { Thermal properties } \\
\text { measurements in } \\
\text { biodiesel oils using } \\
\text { photothermal } \\
\text { techniques }\end{array}$ & $\begin{array}{l}\text { M.P.P Castro, } \\
\text { A.A. Andrade, } \\
\text { R.W. Franco, } \\
\text { PCML } \\
\text { Miranda, } \\
\text { M. Sthel, } \\
\text { H. Vargas, } \\
\text { R. Constantino, } \\
\text { M.L. Baesso }\end{array}$ & $\begin{array}{l}\text { Chemical } \\
\text { Physics } \\
\text { letters }\end{array}$ & $\begin{array}{ll}41 & 1-3 \\
1 & \end{array}$ & $\begin{array}{l}18- \\
22\end{array}$ & $\begin{array}{l}\Rightarrow \text { This paper recommends the use of } \\
\text { thermal lens and photoacoustic } \\
\text { techniques as complementary } \\
\text { methods to existing established } \\
\text { procedures to certify biodiesel blends } \\
\text { that can be used in diesel engines } \\
\Rightarrow \text { In particular, thermal properties } \\
\text { including thermal diffusivity, } \\
\text { effusivity and conductivity of } \\
\text { biodiesel obtained from castor, soy }\end{array}$ \\
\hline
\end{tabular}


and turnip were measured to a fair degree of accuracy using thermal lens and photoacoustic techniques discussed in the paper

\begin{tabular}{|c|c|c|c|c|c|c|c|c|c|}
\hline 44 & $\begin{array}{l}200 \\
6\end{array}$ & $\begin{array}{lr}\text { Alternative } & \text { Fuel for a } \\
\text { Standard } & \text { Diesel } \\
\text { Engine } & \end{array}$ & $\begin{array}{l}\text { A. Hull, } \\
\text { I. Golubkov, } \\
\text { K. Kronberg, } \\
\text { J. Van Stam }\end{array}$ & $\begin{array}{l}\text { International } \\
\text { Journal of } \\
\text { Engine } \\
\text { Research }\end{array}$ & 7 & 1 & $\begin{array}{l}51- \\
63\end{array}$ & $\begin{array}{l}\Rightarrow \\
\Rightarrow \\
\Rightarrow\end{array}$ & $\begin{array}{l}\text { The study demonstrates the } \\
\text { development of a fuel blend from a } \\
\text { variety of oxygenates including } \\
\text { alcohol, esters, acetals etc by } \\
\text { systematic elimination } \\
\text { The proposed fuel, containing } 15 \% \\
\text { oxygenates, satisfies all standards } \\
\text { regarding properties for diesel fuel } \\
\text { blends. } \\
\text { Engine tests indicated that PM } \\
\text { emissions were reduced by } 37 \% \text { and } \\
\text { CO2 decreased by } 15 \%\end{array}$ \\
\hline 45 & $\begin{array}{l}200 \\
5\end{array}$ & $\begin{array}{l}\text { Vapor Pressure and } \\
\text { Normal Boiling Point } \\
\text { Predictions for Pure } \\
\text { Methyl Esters and } \\
\text { Biodiesel Fuels }\end{array}$ & $\begin{array}{l}\text { W. Yuan, } \\
\text { A.C. Hansen, } \\
\text { Q. Zhang }\end{array}$ & Fuel & 84 & $7-8$ & $\begin{array}{l}943- \\
950\end{array}$ & & $\begin{array}{l}\text { Antoine equation and a group } \\
\text { contribution scheme was used to } \\
\text { determine the vapor pressure of } \\
\text { fourteen pure fatty acid methyl esters } \\
\text { (FAME). } \\
\text { A correlation is suggested to estimate } \\
\text { the normal boiling points of FAME. } \\
\text { The normal boiling points of } \\
\text { Fourteen pure fatty acid methyl esters } \\
\text { were predicted within a } 1.5 \mathrm{~K} \text { error. } \\
\text { The normal boiling points were also } \\
\text { determined by the predicted vapor }\end{array}$ \\
\hline
\end{tabular}


pressure from the Antoine equation and the prediction errors were less than $5 \mathrm{~K}$ compared to published data.

$\Rightarrow$ The vapor pressures of nineteen biodiesel fuels were predicted by a weighted mass average of each pure component of ester blends.

Predictions of vapor pressures and boiling points of the biodiesel blends were within 1 percent error of published data

\begin{tabular}{|c|c|c|c|c|c|c|c|c|}
\hline 46 & $\begin{array}{l}200 \\
6\end{array}$ & $\begin{array}{l}\text { An Empirical } \\
\text { Approach in Predicting } \\
\text { Biodiesel Viscosity at } \\
\text { Various Temperatures }\end{array}$ & $\begin{array}{l}\text { Kanit } \\
\text { Krisnangkura, } \\
\text { Tawatchai } \\
\text { Yimsuwan, } \\
\text { Ratanachai } \\
\text { Pairintra }\end{array}$ & Fuel & 85 & 1 & $\begin{array}{l}107- \\
113\end{array}$ & $\begin{array}{l}\Rightarrow \text { Provide thermodynamic correlations } \\
\text { to predict viscosity of saturated } \\
\text { FAMEs between a narrow range of } \\
\text { temperatures }\left(20 \text { to } 80^{\circ} \mathrm{C}\right) \\
\Rightarrow \text { Authors noted that exceeding the } \\
\text { temperature bounds decreases } \\
\text { prediction accuracy. } \\
\Rightarrow \text { The difference between experimental } \\
\text { and published values for viscosity to } \\
\text { lie within accepted range of } \\
\text { accuracies over the given range of } \\
\text { temperatures. }\end{array}$ \\
\hline 47 & $\begin{array}{l}200 \\
6\end{array}$ & $\begin{array}{l}\text { The Densities of Three } \\
\text { Biodiesel Fuels at } \\
\text { Temperatures up to } \\
300 \mathrm{C}\end{array}$ & $\begin{array}{l}\text { R.E. Tate, } \\
\text { K.C. Watts, } \\
\text { C.A. Allen, } \\
\text { K.I. Wilkie }\end{array}$ & Fuel & 85 & $7-8$ & $\begin{array}{l}1004 \\
- \\
1009\end{array}$ & $\begin{array}{l}\Rightarrow \text { A densitometer was developed to } \\
\text { estimate the densities of biodiesel } \\
\text { blends over a temperature range of } \\
20^{\circ}-300^{\circ} \mathrm{C} \text {. Densities of methyl } \\
\text { esters based on Canola, Soy and fish } \\
\text { oil were determined and the data } \\
\text { repatability was found to be within } \\
1 \% \text {. }\end{array}$ \\
\hline
\end{tabular}


$\Rightarrow$ Density of the methyl esters was found to decrease linearly with increasing temperatures

$\Rightarrow$ Density predictions in published literature were found to deviate significantly from the experimental data published in this work especially after $100^{\circ} \mathrm{C}$

\begin{tabular}{|c|c|c|c|c|c|c|c|c|c|}
\hline 48 & $\begin{array}{l}200 \\
6\end{array}$ & $\begin{array}{l}\text { The Viscosities of } \\
\text { Three Biodiesel Fuels } \\
\text { at Temperatures up to } \\
300 \mathrm{C}\end{array}$ & $\begin{array}{l}\text { R.E. Tate, } \\
\text { K.C. Watts, } \\
\text { C.A. Allen, } \\
\text { K.I. Wilkie, }\end{array}$ & Fuel & 85 & $7-8$ & $\begin{array}{l}1010 \\
- \\
1015\end{array}$ & $\begin{array}{l}\Rightarrow \\
\Rightarrow \\
\Rightarrow\end{array}$ & $\begin{array}{l}\text { A modified Saybolt viscometer was } \\
\text { designed to measure the viscosities of } \\
\text { biodiesel blends. } \\
\text { The viscosities of three commercial } \\
\text { biodiesel fuels, canola soy and fish } \\
\text { oil ethyl esters, were observed to } \\
\text { decrease with temperature, in } \\
\text { accordance with predictions by a } \\
\text { modified Andrade equation. } \\
\text { Predicted and low temperature } \\
\text { experimental values of kinematic } \\
\text { viscosities of soy methyl esters in } \\
\text { literature compare very well with } \\
\text { those obtained in this work. }\end{array}$ \\
\hline 49 & $\begin{array}{l}200 \\
7\end{array}$ & $\begin{array}{l}\text { Flow Properties of } \\
\text { Biodiesel Fuel Blends } \\
\text { at Low Temperatures }\end{array}$ & $\begin{array}{l}\text { Rushang } \\
\text { Joshi, } \\
\text { Michael } \\
\text { Pegg. }\end{array}$ & $\begin{array}{ll}\text { M. } & \text { Fuel } \\
\text { J. } & \end{array}$ & 86 & $1-2$ & $\begin{array}{l}143- \\
151\end{array}$ & $\begin{array}{l}\Rightarrow \\
\Rightarrow\end{array}$ & $\begin{array}{l}\text { The cloud point and pour point of } \\
\text { biodiesel, no. } 2 \text { diesel fuel and B20, } \\
\text { B40, B } 60 \text { and B } 80 \text { blends, have been } \\
\text { made. In all cases the cloud point and } \\
\text { pour point of biodiesel was observed } \\
\text { to decrease with increase in } \\
\text { concentration of no. } 2 \text { diesel. } \\
\text { Empirical methods were developed to } \\
\text { determine accurate predictions for the } \\
\text { cloud and pour points based on a }\end{array}$ \\
\hline
\end{tabular}




\begin{tabular}{|c|c|c|c|c|}
\hline & & & $\begin{array}{l}\Rightarrow \\
\Rightarrow\end{array}$ & $\begin{array}{l}\text { given concentration } \\
\text { The dynamic viscosity of biodiesel } \\
\text { and its blends increases as } \\
\text { temperature decreases and show } \\
\text { Newtonian behaviour down to the } \\
\text { pour point. } \\
\text { Dynamic viscosity, cloud point and } \\
\text { pour point decreases with increasing } \\
\text { concentration of \# } 2 \text { diesel }\end{array}$ \\
\hline $\begin{array}{ll}50 & 200 \\
& 4\end{array}$ & $\begin{array}{ll}\text { The Specific Gravity } & \text { Wenqiao Yuan, } \\
\text { of Biodiesel Fuels and } & \text { Alan C. } \\
\text { their Blends with } & \text { Hansen, } \\
\text { Diesel Fuel } & \text { Qin Zhang }\end{array}$ & $\begin{array}{l}\text { Agricultural VI } \\
\text { Engineering } \\
\text { International } \\
: \text { the CIGR } \\
\text { Journal of } \\
\text { Scientific } \\
\text { Research } \\
\text { and } \\
\text { Developmen } \\
\text { t. }\end{array}$ & $\begin{array}{l}\Rightarrow \\
\Rightarrow \\
\Rightarrow \\
\Rightarrow\end{array}$ & $\begin{array}{l}\text { The specific gravity of three } \\
\text { biodiesel fuels, two soybean oil based } \\
\text { methyl esters and a yellow grease } \\
\text { methyl ester, and their } 75,50 \text { and } \\
25 \% \text { blends with No. } 2 \text { diesel fuel } \\
\text { were measured in the temperature } \\
\text { range from about }-5^{\circ} \mathrm{C} \text { to } 100{ }^{\circ} \mathrm{C} \text {. } \\
\text { The measurements indicated that all } \\
\text { the biodiesel fuels and their blends } \\
\text { with No. } 2 \text { diesel fuel had a linear } \\
\text { specific gravity-temperature } \\
\text { relationship similar to No.2 diesel } \\
\text { fuel. } \\
\text { The specific gravities of the blends of } \\
\text { biodiesel and No. } 2 \text { diesel were found } \\
\text { to be proportional to the mass } \\
\text { fraction of the components. This } \\
\text { proportionality was used to estimate } \\
\text { the specific gravities of the blends of } \\
\text { biodiesel and diesel with an error in } \\
\text { estimation of about } 0.15 \% \text { of } \\
\text { measured data for all tested fuels } \\
\text { from } 0{ }^{\circ} \mathrm{C} \text { to } 80^{\circ} \mathrm{C} \text {. }\end{array}$ \\
\hline
\end{tabular}




\begin{tabular}{|c|c|c|c|c|c|c|c|c|c|}
\hline 51 & $\begin{array}{l}200 \\
4\end{array}$ & $\begin{array}{l}\text { A phenomenological } \\
\text { model for the } \\
\text { prediction of soot } \\
\text { formation in diesel } \\
\text { spray combustion }\end{array}$ & $\begin{array}{lr}\text { Feng } & \text { Tao, } \\
\text { Valeri } & \text { I. } \\
\text { Golovitchev, } \\
\text { and Jerzy } \\
\text { Chomiak }\end{array}$ & $\begin{array}{l}\text { Combustion } \\
\text { and } \\
\text { flame (Com } \\
\text { bust. } \\
\text { flame) ISS } \\
\text { N 0010- } \\
2180\end{array}$ & $\begin{array}{l}13 \\
6\end{array}$ & 3 & $\begin{array}{l}270- \\
282\end{array}$ & $\begin{array}{l}\Rightarrow \\
\Rightarrow \\
\Rightarrow \\
\Rightarrow \\
\Rightarrow\end{array}$ & $\begin{array}{l}\text { The prototype of the model is one } \\
\text { proposed by Leung and Lindstedt in } \\
\text { which soot formation is treated by } \\
\text { four global stages: particle } \\
\text { nucleation, surface growth, surface } \\
\text { oxidation, and particle coagulation. } \\
\text { The formation of soot particles is } \\
\text { linked with gas-phase chemistry via } \\
\text { diacetylene and naphthalene, which } \\
\text { are presumed to be indicative species } \\
\text { of particle inception/nucleation. } \\
\text { The soot surface growth is described } \\
\text { using Frenklach et al.'s active site } \\
\text { model, and the oxidation mechanism } \\
\text { includes both Nagle and Strickland- } \\
\text { Constable's O2 oxidation and Neoh } \\
\text { et al.'s OH oxidation models. } \\
\text { The turbulent flow is predicted using } \\
\text { the compressible k-E model, and the } \\
\text { turbulence-chemistry interaction } \\
\text { handled by a partially stirred reactor } \\
\text { model. }\end{array}$ \\
\hline 52 & $\begin{array}{l}200 \\
6\end{array}$ & \begin{tabular}{l}
\multicolumn{2}{l}{ Quasidimensional } \\
Modeling of Direct \\
Injection \\
Engine Nitric Oxide, \\
Soot, and Unburned \\
Hydrocarbon \\
Emissions
\end{tabular} & $\begin{array}{c}\text { Dohoy Jung, } \\
\text { Dennis N. } \\
\text { Assanis }\end{array}$ & $\begin{array}{l}\text { Transactions } \\
\text { of the } \\
\text { ASME }\end{array}$ & $\begin{array}{l}12 \\
8\end{array}$ & & & $\begin{array}{l}\Rightarrow \\
\Rightarrow\end{array}$ & $\begin{array}{l}\text { The Zeldovich mechanism is used for } \\
\text { predicting NO emissions. Soot } \\
\text { formation and oxidation is calculated } \\
\text { with a semiempirical, two-rate } \\
\text { equation model. } \\
\text { Unburned HC emissions models } \\
\text { account for three major HC sources } \\
\text { in DI diesel engines: (1) leaned-out } \\
\text { fuel during the ignition delay, (2) fuel } \\
\text { yielded by the sac volume and nozzle } \\
\text { hole, and (3) overpenetrated fuel. }\end{array}$ \\
\hline
\end{tabular}


$\Rightarrow$ The usefulness of the cycle simulation as a practical design tool is demonstrated with a case study of the effect of the discharge coefficient of the injector nozzle on pollutant emissions.

\begin{tabular}{|c|c|c|c|c|c|c|c|c|c|}
\hline 53 & $\begin{array}{l}200 \\
5\end{array}$ & $\begin{array}{l}\text { Numerical Simulation } \\
\text { of the Gas/Deisel } \\
\text { Dual-Fuel Engine In- } \\
\text { cylinder Combustion } \\
\text { Process }\end{array}$ & $\begin{array}{c}\text { Haiyan Miao } \\
\text { and Brian } \\
\text { Milton }\end{array}$ & $\begin{array}{l}\text { Numerical } \\
\text { Heat } \\
\text { Transfer }\end{array}$ & 47 & $\mathrm{~A}$ & $\begin{array}{l}523- \\
547\end{array}$ & $\begin{array}{l}\Rightarrow \\
\Rightarrow \\
\Rightarrow \\
\Rightarrow \\
\Rightarrow\end{array}$ & $\begin{array}{l}\text { Representative case studies illustrate } \\
\text { the code's value for analyzing the } \\
\text { combustion in dual-fuel engines. It } \\
\text { can examine many parameters, such } \\
\text { as the in-cylinder pressure, } \\
\text { temperature, and fuel consumption } \\
\text { rate, from which heat release rate and } \\
\text { engine power output can be } \\
\text { determined. } \\
\text { The three-dimensional data provide } \\
\text { detailed information on the flame } \\
\text { development, the relative } \\
\text { contribution of the individual fuels, } \\
\text { and the emission formation. } \\
\text { The ignition-delay period is } \\
\text { lengthened by an increased natural } \\
\text { gas proportion; an early auto-ignition } \\
\text { of the ethane in the gas occurs and } \\
\text { different heat release rates exist for } \\
\text { different gas proportions, depending } \\
\text { on the oxygen availability in the } \\
\text { appropriate regions of the } \\
\text { combustion chamber. }\end{array}$ \\
\hline
\end{tabular}




\begin{tabular}{cclll}
\hline 54200 & Modeling the Effects & Feng Tao, Yi SAE -2005- \\
5 & of EGR and Injection & Liu, Bret H. & $01-0121$ \\
Pressure on Soot & RempelEwert, & \\
Formation in a High- & David E. Foster \\
Speed Direct-Injection & and Rolf D. \\
(HSDI) Diesel Engine & Reitz Dae Choi \\
Using a Multi-Step & and Paul C. \\
& Phenomenological & Miles &
\end{tabular}

Soot Model

$\Rightarrow$ This multi-step soot model includes particle inception, surface growth, surface oxidation, and particle coagulation. Additional models include a piston-ring crevice model, the KH/RT spray breakup model, a droplet wall impingement model, a wall heat transfer model, and the

RNG k- $\square$ turbulence model.

$\Rightarrow$ The Shell model was used to simulate the ignition process, and a laminarand-turbulent characteristic time combustion model was used for the post-ignition combustion process. A low-load (IMEP=3 bar) operating condition was considered and the predicted in-cylinder pressures and heat release rates were compared with measurements.

$\Rightarrow$ The predictions demonstrate that both EGR and retarded injection are beneficial for reducing NOx emissions. Higher soot emissions are typically predicted for the higher EGR rates, lower injection pressures or increased injection timings. However, when the EGR rate exceeds a critical value (over $65 \%$ in this study), the soot emissions decrease. Reduced soot emissions are also predicted when are employed. 


\begin{tabular}{|c|c|c|c|c|c|c|}
\hline 55 & $\begin{array}{l}200 \\
5\end{array}$ & $\begin{array}{l}\text { Modeling Approaches } \\
\text { for Premixed Charge } \\
\text { Compression Ignition } \\
\text { Combustion }\end{array}$ & $\begin{array}{l}\text { Carl-Anders } \\
\text { Hergart, Hardo } \\
\text { Barths and } \\
\text { Robert M. } \\
\text { Siewert }\end{array}$ & $\begin{array}{l}\text { SAE - 2005- } \\
01-0218\end{array}$ & $\begin{array}{l}\Rightarrow \\
\Rightarrow \\
\Rightarrow \\
\Rightarrow\end{array}$ & $\begin{array}{l}\text { The Representative Interactive } \\
\text { Flamelet (RIF) - model has } \\
\text { established itself as a model well } \\
\text { suited for capturing conventional } \\
\text { non-premixed combustion in diesel } \\
\text { engines. } \\
\text { The model is successfully applied to } \\
\text { the so-called Premixed Charge } \\
\text { Compression Ignition (PCCI) mode } \\
\text { of combustion, characterized by } \\
\text { relatively early injection timings, } \\
\text { high EGR, and cooled intake air. } \\
\text { For very advanced injection timings, } \\
\text { an alternative modeling approach is } \\
\text { developed. This is based on a } \\
\text { sequential treatment of the in- } \\
\text { cylinder processes, where the } \\
\text { injection process and fluid dynamics } \\
\text { are modeled using the three- } \\
\text { dimensional CFD-code GMTEC and } \\
\text { the chemical reactions are treated in a } \\
\text { multi-zone chemistry code, } \\
\text { developed at GM. }\end{array}$ \\
\hline 56 & $\begin{array}{l}200 \\
5\end{array}$ & $\begin{array}{l}\text { Thermodynamic } \\
\text { Modeling of Jet } \\
\text { Formation and } \\
\text { Combustion in } \\
\text { Common Rail Multi- } \\
\text { Jet Diesel Engines }\end{array}$ & $\begin{array}{l}\text { I. Arsie, F. Di } \\
\text { Genova, C. } \\
\text { Pianese and G. } \\
\text { Rizzo } \\
\text { A. Caraceni, P. } \\
\text { Cioffi and G. } \\
\text { Flauti }\end{array}$ & $\begin{array}{l}\text { SAE - 2005- } \\
01-1121\end{array}$ & $\begin{array}{l}\Rightarrow \\
\Rightarrow\end{array}$ & $\begin{array}{l}\text { The modeling approach is based on a } \\
\text { semi-empirical two-zone combustion } \\
\text { model coupled with identification } \\
\text { analysis in order to implement a } \\
\text { predictive tool for simulating the } \\
\text { effects of control injection strategies } \\
\text { on combustion and exhaust } \\
\text { emissions. } \\
\text { Fuel jet formation and combustion } \\
\text { for both premixed and diffusive }\end{array}$ \\
\hline
\end{tabular}




\begin{tabular}{|c|c|c|c|c|c|}
\hline 57 & $\begin{array}{l}\text { Modeling the Effects } \\
\text { of EGR on a Heavy } \\
\text { Duty DI Diesel Engine } \\
\text { Using a new Quasi- } \\
\text { Dimensional } \\
\text { Combustion Model }\end{array}$ & $\begin{array}{l}\text { E. G. Pariotis, } \\
\text { D. T. Hountalas } \\
\text { and C. D. } \\
\text { Rakopoulos }\end{array}$ & $\begin{array}{l}\text { SAE - 2005- } \\
01-1125\end{array}$ & & $\begin{array}{l}\text { The model has been modified to take } \\
\text { into account the effect of EGR, since } \\
\text { the latter one is a measure that will be } \\
\text { used more extensively in the future to } \\
\text { control NO emissions from } \\
\text { turbocharged HDDI Diesel engines. }\end{array}$ \\
\hline $\begin{array}{ll}58 & 200 \\
& 6\end{array}$ & $\begin{array}{c}\text { Modeling Diesel } \\
\text { Engine NOx and Soot } \\
\text { Reduction with } \\
\text { Optimized Two-Stage } \\
\text { Combustion }\end{array}$ & $\begin{array}{l}\text { Yong Sun and } \\
\text { Rolf D. Reitz }\end{array}$ & $\begin{array}{l}\text { SAE } \\
2006-01- \\
0027\end{array}$ & $\Rightarrow$ & $\begin{array}{l}\text { A multi-dimensional Computational } \\
\text { Fluid Dynamics (CFD) code with } \\
\text { detailed chemistry, the } \\
\text { KIVACHEMKIN-GA code, was } \\
\text { employed in this study, where } \\
\text { Genetic Algorithms (GA) were used } \\
\text { to optimize heavy duty diesel engine } \\
\text { operating parameters. }\end{array}$ \\
\hline
\end{tabular}

regimes are predicted, by dividing the combustion chamber into two control volumes; these account for the fuel jet and the surrounding air, composed by fresh air and residual gases; the fuel jet is divided into two zones to separate liquid and vapor phases.

$\Rightarrow$ The simulation results have shown that the model predicts the effects of different injection parameters in case of single and multiple injections in a short computational time, suitable for the accomplishment of intensive simulations or optimization analyses over generic engine driving cycles. the latter one is a measure that will be used more extensively in the future to control NO emissions from

Dimensional operating parameters. 
$\Rightarrow$ Two combustion mode i.e. HCCI combustion and diffusion combustion under high temperature and low oxygen concentration conditions proved to have great potential to meet future ultra-low emission standards.

$\Rightarrow$ Combining Intake Valve Closure (IVC) timing, Exhaust Gas

Recirculation (EGR) ratio, Start of Late Injection (SOLI) timing and the fraction of fuel in HCCI combustion was able to achieve low engine-out emissions.

$\begin{array}{lllll}59 & 200 & \text { Development and } & \text { M. Baratta, A. SAE }\end{array}$

6 Assessment of a

Multizone Combustion

Simulation Code for SI

Engines Based on a

Novel Fractal Model

\section{E. Catania, E. 2006-01-}

Spessa and A. 0048

Vassallo

$\Rightarrow$ A combustion simulation code for the prediction of heat release, flame propagation speed and pollutant formation in SI engines was developed and assessed. It is based on a multi-zone combustion model that takes the non-uniform spatial distribution of the in-cylinder burnedgas thermo-chemical properties into account.

$\Rightarrow$ The multi-zone approach for burning rate calculation is coupled with a CAD procedure for the evaluation of burned-gas front area and radius. Specifically developed sub-models for determining $\mathrm{CO}$ and $\mathrm{NO}$ formation are included in the code.

$\Rightarrow$ The authors' flame-propagation model led to an accurate prediction of the flame-turbulence interaction 
\begin{tabular}{ccc}
\hline 60 & 200 & Multizones Modeling \\
& 6 & of the Combustion \\
& & Characteristics of \\
& & Oxygenated Fuels in
\end{tabular} CI Engines

\author{
Anwer Saeed, SAE \\ Khizer Saeed, 2006-01- \\ Akhlaq Ahmad \\ and Khursheed \\ A. Malik
}

during the overall combustion period,

from early flame development to

flame extinction. In addition, it does

not require flame kernel growth and

burnout sub-models as conventional

correlations do for combustion stages

in which fine-scale turbulence is

reduced and the outer length-scale

cutoff is linked to the flame size.

$\Rightarrow$ There exists a temperature difference inside the burned gas region of the internal combustion engines due to the recompression effect inside the burned gas region.

$\Rightarrow$ Zero-dimensional multi-zone model developed at Oxford Engine Research Group is implemented to investigate the generation of the temperature difference inside the burned gas region and qualitatively model the combustion characteristics within compression ignition (CI) engines.

$\Rightarrow$ Results for the variation in the burned gas temperature and NOx formation within the different zones of the ten zones model and compared with the single zone. Single zone model is found to give under-prediction in burned gas temperature as well as NOx for all the three fuels (diesel, methanol and dimethyl ether). The ten zones model shows the 
generation of the temperature difference within the burned gas region.

\begin{tabular}{|c|c|c|c|c|c|c|}
\hline 61 & $\begin{array}{l}200 \\
6\end{array}$ & $\begin{array}{l}\text { Comparison of the } \\
\text { Characteristic Time } \\
\text { (CTC), Representative } \\
\text { Interactive Flamelet } \\
\text { (RIF), and Direct } \\
\text { Integration with } \\
\text { Detailed } \\
\text { Chemistry Combustion } \\
\text { Models against Optical } \\
\text { Diagnostic Data } \\
\text { for Multi-Mode } \\
\text { Combustion in a } \\
\text { Heavy-Duty DI Diesel } \\
\text { Engine }\end{array}$ & $\begin{array}{l}\text { Satbir Singh } \\
\text { and Rolf D. } \\
\text { Reitz } \\
\text { Mark P. B. } \\
\text { Musculus }\end{array}$ & $\begin{array}{l}\text { SAE - 2006- } \\
01-0055\end{array}$ & $\Rightarrow$ & $\begin{array}{l}\text { A characteristic time combustion } \\
\text { (KIVA-CTC) model, a representative } \\
\text { interactive flamelet (KIVA-RIF) } \\
\text { model, and direct integration using } \\
\text { detailed chemistry (KIVA- } \\
\text { CHEMKIN) are compared against } \\
\text { cylinder pressure, NOx emissions, } \\
\text { high-speed soot luminosity imaging, } \\
\text { and 2-color thermometry data from a } \\
\text { heavy-duty DI diesel engine. } \\
\text { Five different engine operating } \\
\text { strategies that are representative of } \\
\text { several different combustion regimes } \\
\text { were explored in the experiments and } \\
\text { model simulations. Two of the } \\
\text { strategies produce high-temperature } \\
\text { combustion with different ignition } \\
\text { delays, while the other three use } \\
\text { dilution to achieve low-temperature } \\
\text { combustion (LTC), with early, late, or } \\
\text { multiple injections. }\end{array}$ \\
\hline 62 & $\begin{array}{l}200 \\
3\end{array}$ & $\begin{array}{l}\text { Numerical Modeling } \\
\text { of Diesel Engine } \\
\text { Combustion and } \\
\text { Emissions Under } \\
\text { HCCI-Like Conditions } \\
\text { With High EGR Levels }\end{array}$ & $\begin{array}{l}\text { Song-Charng } \\
\text { Kong, Amar } \\
\text { Patel, Qi Yin, } \\
\text { Adam } \\
\text { Klingbeil and } \\
\text { Rolf D. Reitz }\end{array}$ & $\begin{array}{l}\text { SAE - 2003- } \\
01-1087\end{array}$ & $\Rightarrow$ & $\begin{array}{l}\text { The ignition and combustion } \\
\text { processes were simulated using both } \\
\text { detailed and standard (simplified) } \\
\text { chemistry models. } \\
\text { The present model was also used for } \\
\text { engine geometry design optimization } \\
\text { in order to achieve low emissions. }\end{array}$ \\
\hline
\end{tabular}


$\Rightarrow$ It was found that open-chamber type geometry with high EGR and high swirl ratio was preferred to obtain HCCI-like combustion characteristics by creating a more homogeneous mixture in the cylinder.

\begin{tabular}{|c|c|c|c|c|c|c|c|}
\hline 63 & $\begin{array}{l}200 \\
6\end{array}$ & $\begin{array}{l}\text { Modelling diesel } \\
\text { engine combustion } \\
\text { and NOx formation for } \\
\text { model based control } \\
\text { and simulation of } \\
\text { engine and exhaust } \\
\text { after treatment systems }\end{array}$ & $\begin{array}{l}\text { Ericson, Claes; } \\
\text { Westerberg, } \\
\text { Bjoern; } \\
\text { Andersson, } \\
\text { Magnus; } \\
\text { Egnell, Rolf. } \\
\text { Scania CV AB, } \\
\text { Swed. }\end{array}$ & $\begin{array}{l}\text { Society of } \\
\text { Automotive } \\
\text { Engineers, } \\
\text { [Special } \\
\text { Publication] } \\
\text { SP (2006) } \\
\text { SP- } \\
\text { 2023(Diesel } \\
\text { Exhaust } \\
\text { Emission } \\
\text { Control } \\
\text { Modeling } \\
\text { 2006) }\end{array}$ & $\begin{array}{l}211- \\
235\end{array}$ & $\begin{array}{l}\Rightarrow \\
\Rightarrow \\
\Rightarrow\end{array}$ & $\begin{array}{l}\text { This paper is focused on the } \\
\text { calculation of engine-out NOx and } \\
\text { engine parameters such as cylinder } \\
\text { pressure, temp. and gas flows. } \\
\text { A quasi steady gas exchange model } \\
\text { (including models for EGR and } \\
\text { VGT) is combined with a two-zone } \\
\text { zero dimensional combustion model. } \\
\text { The combustion model uses fuel flow } \\
\text { parameters to generate heat release } \\
\text { data and calculates the corresponding } \\
\text { pressure trace. } \\
\text { The temperature and equilibrium } \\
\text { concentrations in the zones are } \\
\text { calculated by the simplified } \\
\text { combustion model and the } \\
\text { corresponding NOx concentration is } \\
\text { given by the original Zeldovich } \\
\text { mechanism. }\end{array}$ \\
\hline
\end{tabular}


Table A.2. Physical Properties of Biodiesel

\begin{tabular}{|c|c|c|c|c|c|c|c|c|c|c|c|}
\hline Fuel Blend & Viscosity & Density & $\begin{array}{l}\text { Cetane } \\
\text { Number }\end{array}$ & $\begin{array}{l}\text { Flash } \\
\text { Point }\end{array}$ & $\begin{array}{l}\text { Specific } \\
\text { Gravity }\end{array}$ & $H H V$ & $L H V$ & $\begin{array}{l}\text { Cloud } \\
\text { Point }\end{array}$ & $\begin{array}{l}\text { Pour } \\
\text { Point }\end{array}$ & $\begin{array}{l}\text { Iodine } \\
\text { Number }\end{array}$ & Source \\
\hline No2 Diesel & $\begin{array}{c}2.6 \\
\mathrm{Cs} @ 40 \\
\mathrm{C}\end{array}$ & -- & $40-52$ & $\begin{array}{l}60- \\
72\end{array}$ & .850 & $\begin{array}{c}19300 \\
\text { BTU/lb }\end{array}$ & $\begin{array}{c}18640 \\
\text { BTU/lb }\end{array}$ & $\begin{array}{c}-15 \text { to } \\
5 \mathrm{C}\end{array}$ & $\begin{array}{c}-35 \\
\text { to } \\
-15 \\
C\end{array}$ & 8.6 & $\begin{array}{l}\text { (Graboski) Prog. } \\
\text { Energy } \\
\text { Combustion } \\
\text { Science Volume } \\
24, \text { pp. 125-164, } \\
\text { 1998 Elsevier } \\
\text { Science Ltd. }\end{array}$ \\
\hline
\end{tabular}




\begin{tabular}{|c|c|c|c|c|c|c|c|c|c|c|c|}
\hline $\begin{array}{l}\text { Soybean } \\
\text { Methylester }\end{array}$ & $\begin{array}{c}4.08 \\
\text { Cs @ } 40 \\
\text { C }\end{array}$ & -- & 50.9 & $\begin{array}{c}131 \\
\mathrm{C}\end{array}$ & 8853 & $\begin{array}{c}17355 \\
\text { BTU/lb }\end{array}$ & $\begin{array}{c}15925 \\
\text { BTU/lb }\end{array}$ & $\begin{array}{c}-0.5 \\
C\end{array}$ & $\begin{array}{c}-3.8 \\
\mathrm{C}\end{array}$ & 133.2 & $\begin{array}{l}\text { (Graboski) Prog. } \\
\text { Energy } \\
\text { Combustion } \\
\text { Science Volume } \\
24, \text { pp. 125-164, } \\
1998 \text { Elsevier } \\
\text { Science Ltd. }\end{array}$ \\
\hline $\begin{array}{ll}\text { Rapeseed } & \text { Oil } \\
\text { Methylester } & \end{array}$ & $\begin{array}{c}4.83 \\
\text { Cs @ } 40 \\
\text { C }\end{array}$ & -- & 52.9 & $\begin{array}{c}170 \\
\mathrm{C}\end{array}$ & .8820 & $\begin{array}{c}17363 \\
\text { BTU/lb }\end{array}$ & $\begin{array}{c}16050 \\
\text { BTU/lb }\end{array}$ & $\begin{array}{c}-4.0 \\
\mathrm{C}\end{array}$ & $\begin{array}{c}-10.8 \\
\mathrm{C}\end{array}$ & -- & $\begin{array}{l}\text { (Graboski) Prog. } \\
\text { Energy } \\
\text { Combustion } \\
\text { Science Volume } \\
24, \text { pp. 125-164, } \\
1998 \text { Elsevier } \\
\text { Science Ltd. }\end{array}$ \\
\hline $\begin{array}{l}\text { Tallow } \\
\text { Methylester }\end{array}$ & $\begin{array}{c}4.80 \\
\text { Cs @ } 40 \\
\text { C }\end{array}$ & -- & -- & $\begin{array}{c}117 \\
\mathrm{C}\end{array}$ & .8756 & $\begin{array}{c}17283 \\
\text { BTU/lb }\end{array}$ & -- & $\begin{array}{c}13.9 \\
\mathrm{C}\end{array}$ & $9.0 \mathrm{C}$ & -- & $\begin{array}{l}\text { (Graboski) Prog. } \\
\text { Energy } \\
\text { Combustion } \\
\text { Science Volume } \\
24, \text { pp. 125-164, } \\
1998 \text { Elsevier } \\
\text { Science Ltd. }\end{array}$ \\
\hline $\begin{array}{l}\text { Soybean } \\
\text { Methylester }\end{array}$ & $\begin{array}{l}4.08 \\
\text { cSt @ } \\
40 \mathrm{C}\end{array}$ & $\begin{array}{c}0.884 \\
\mathrm{~g} / \mathrm{cc} @ \\
15.5 \mathrm{C}\end{array}$ & 46.2 & -- & -- & -- & $\begin{array}{c}39.8 \\
\mathrm{MJ} / \mathrm{kg}\end{array}$ & $2.0 \mathrm{C}$ & -- & -- & $\begin{array}{l}\text { (L. Davis } \\
\text { Clements) } \\
\text { Biological } \\
\text { Systems } \\
\text { Engineering at } \\
\text { the University of } \\
\text { Lincoln } \\
\text { Nebraska. }\end{array}$ \\
\hline
\end{tabular}




\begin{tabular}{|c|c|c|c|c|c|c|c|c|c|c|c|}
\hline Palm Methylester & $\begin{array}{c}5.7 \\
\mathrm{cSt} @ \\
40 \mathrm{C}\end{array}$ & $\begin{array}{c}0.880 \\
\mathrm{~g} / \mathrm{cc} @ \\
15.5 \mathrm{C}\end{array}$ & 62 & -- & -- & -- & $\begin{array}{c}37.8 \\
\mathrm{MJ} / \mathrm{kg}\end{array}$ & $\begin{array}{c}13.0 \\
\mathrm{C}\end{array}$ & -- & -- & $\begin{array}{l}\text { (L. Davis } \\
\text { Clements) } \\
\text { Biological } \\
\text { Systems } \\
\text { Engineering at } \\
\text { the University of } \\
\text { Lincoln } \\
\text { Nebraska. }\end{array}$ \\
\hline $\begin{array}{l}\text { Sunflower } \\
\text { Methylester }\end{array}$ & $\begin{array}{c}4.6 \\
\mathrm{cSt} @ \\
40 \mathrm{C}\end{array}$ & $\begin{array}{l}0.880 \\
\text { g/cc @ } \\
15.5 \mathrm{C}\end{array}$ & 49 & -- & -- & -- & $\begin{array}{c}38.1 \\
\mathrm{MJ} / \mathrm{kg}\end{array}$ & $1.0 \mathrm{C}$ & -- & -- & $\begin{array}{l}\text { (L. Davis } \\
\text { Clements) } \\
\text { Biological } \\
\text { Systems } \\
\text { Engineering at } \\
\text { the University of } \\
\text { Lincoln } \\
\text { Nebraska. }\end{array}$ \\
\hline $\begin{array}{l}\text { Tallow } \\
\text { Methylester }\end{array}$ & $\begin{array}{l}4.1 \mathrm{cSt} \\
\text { (a) } 40 \mathrm{C}\end{array}$ & $\begin{array}{c}0.877 \\
\mathrm{~g} / \mathrm{cc} @ \\
15.5 \mathrm{C}\end{array}$ & 58 & -- & -- & -- & $\begin{array}{c}39.9 \\
\mathrm{MJ} / \mathrm{kg}\end{array}$ & $\begin{array}{c}12.0 \\
\mathrm{C}\end{array}$ & -- & -- & $\begin{array}{l}\text { (L. Davis } \\
\text { Clements) } \\
\text { Biological } \\
\text { Systems } \\
\text { Engineering at } \\
\text { the University of } \\
\text { Lincoln } \\
\text { Nebraska. }\end{array}$ \\
\hline
\end{tabular}




\begin{tabular}{|c|c|c|c|c|c|c|c|c|c|c|c|}
\hline $\begin{array}{l}\text { BIO-1 } \\
\text { Corn Oil }\end{array}$ & $\begin{array}{l}6.225 \\
\mathrm{cSt} @ \\
30 \mathrm{C}\end{array}$ & $\begin{array}{l}883.9 \\
\mathrm{~kg} / \mathrm{m}^{3}\end{array}$ & 63.9 & $\begin{array}{c}166 \\
C\end{array}$ & -- & -- & $\begin{array}{c}42.3 \\
\mathrm{MJ} / \mathrm{kg}\end{array}$ & -- & -- & -- & $\begin{array}{l}\text { (Koji Yamane) } \\
\text { Fifth } \\
\text { International } \\
\text { Symposium on } \\
\text { Diagnostics and } \\
\text { Modeling of } \\
\text { Combustion in } \\
\text { Internal } \\
\text { Combustion } \\
\text { Engines, July 1- } \\
\text { 4, 2001, Nagoya }\end{array}$ \\
\hline $\begin{array}{l}\text { BIO-2 Rapeseed } \\
\text { Oil }\end{array}$ & $\begin{array}{r}9.49 \\
\mathrm{cSt} @ \\
30 \mathrm{C}\end{array}$ & $\begin{array}{l}895.3 \\
\mathrm{~kg} / \mathrm{m}^{3}\end{array}$ & 53 & $\begin{array}{c}192 \\
C\end{array}$ & -- & -- & $\begin{array}{c}36.7 \\
\mathrm{MJ} / \mathrm{kg}\end{array}$ & -- & -- & -- & $\begin{array}{l}\text { (Koji Yamane) } \\
\text { Fifth } \\
\text { International } \\
\text { Symposium on } \\
\text { Diagnostics and } \\
\text { Modeling of } \\
\text { Combustion in } \\
\text { Internal } \\
\text { Combustion } \\
\text { Engines, July 1- } \\
\text { 4, 2001, Nagoya }\end{array}$ \\
\hline $\begin{array}{l}\text { OME } \\
\text { Methyloleate }\end{array}$ & $\begin{array}{r}6.15 \\
\mathrm{cSt} @, \\
30 \mathrm{C}\end{array}$ & $\begin{array}{l}879.1 \\
\mathrm{~kg} / \mathrm{m}^{3}\end{array}$ & 57.9 & $\begin{array}{c}180 \\
\mathrm{C}\end{array}$ & -- & -- & $\begin{array}{l}37.09 \\
\mathrm{MJ} / \mathrm{kg}\end{array}$ & -- & -- & -- & $\begin{array}{l}\text { (Koji Yamane) } \\
\text { Fifth } \\
\text { International } \\
\text { Symposium on } \\
\text { Diagnostics and } \\
\text { Modeling of } \\
\text { Combustion in } \\
\text { Internal } \\
\text { Combustion } \\
\text { Engines, July 1- } \\
\text { 4, 2001, Nagoya }\end{array}$ \\
\hline
\end{tabular}




\begin{tabular}{|c|c|c|c|c|c|c|c|c|c|c|c|}
\hline $\begin{array}{l}\text { LME } \\
\text { Methyllinoleateas }\end{array}$ & $\begin{array}{c}5.72 \\
\mathrm{cSt} @ \\
30 \mathrm{C}\end{array}$ & $\begin{array}{l}888.2 \\
\mathrm{~kg} / \mathrm{m}^{3}\end{array}$ & 56.1 & $\begin{array}{c}186 \\
C\end{array}$ & -- & -- & $\begin{array}{c}37.08 \\
\mathrm{MJ} / \mathrm{kg}\end{array}$ & -- & -- & -- & $\begin{array}{l}\text { (Koji Yamane) } \\
\text { Fifth } \\
\text { International } \\
\text { Symposium on } \\
\text { Diagnostics and } \\
\text { Modeling of } \\
\text { Combustion in } \\
\text { Internal } \\
\text { Combustion } \\
\text { Engines, July 1- } \\
\text { 4, 2001, Nagoya }\end{array}$ \\
\hline $\begin{array}{l}\text { Frying } \quad \text { Oil } \\
\text { Biodiesel } 100 \%\end{array}$ & $\begin{array}{c}5.1 \\
\mathrm{cSt} @ \\
40 \mathrm{C}\end{array}$ & $\begin{array}{c}0.8815 \\
\mathrm{~kg} / \mathrm{L} @ \\
15 \mathrm{C}\end{array}$ & 58 & $\begin{array}{c}165 \\
\mathrm{C}\end{array}$ & -- & -- & -- & $6.0 \mathrm{C}$ & -- & -- & $\begin{array}{l}\text { (Girish Parvate- } \\
\text { Patil) ASME- } \\
\text { ICED 2006, } \\
\text { Internal } \\
\text { Combustion } \\
\text { Engine Division } \\
\text { Fall Technical } \\
\text { Conference } \\
\text { November 5-8, } \\
\text { 2006, } \\
\text { Sacramento, CA, } \\
\text { USA }\end{array}$ \\
\hline
\end{tabular}




\begin{tabular}{|c|c|c|c|c|c|c|c|c|c|c|c|}
\hline $\begin{array}{l}\text { Frying Oil } \\
\text { Biodiesel 20\% }\end{array}$ & -- & $\begin{array}{c}.8219 \\
\mathrm{~kg} / \mathrm{L} @ \\
15 \mathrm{C}\end{array}$ & 43.8 & $\begin{array}{l}40.5 \\
\mathrm{C}\end{array}$ & -- & -- & -- & $\begin{array}{c}19.0 \\
\mathrm{C}\end{array}$ & -- & -- & $\begin{array}{l}\text { (Girish Parvate- } \\
\text { Patil) ASME- } \\
\text { ICED 2006, } \\
\text { Internal } \\
\text { Combustion } \\
\text { Engine Division } \\
\text { Fall Technical } \\
\text { Conference } \\
\text { November 5-8, } \\
\text { 2006, } \\
\text { Sacramento, CA, } \\
\text { USA }\end{array}$ \\
\hline $\begin{array}{l}\text { Canola Biodiesel } \\
100 \%\end{array}$ & $\begin{array}{l}4.396 \\
\mathrm{cSt} @ \\
40 \mathrm{C}\end{array}$ & $\begin{array}{c}0.8827 \\
\mathrm{~kg} / \mathrm{L} @ \\
15 \mathrm{C}\end{array}$ & 62.7 & $\begin{array}{c}144 \\
\mathrm{C}\end{array}$ & -- & -- & -- & $\begin{array}{c}-2.4 \\
\mathrm{C}\end{array}$ & -- & -- & $\begin{array}{l}\text { (Girish Parvate- } \\
\text { Patil) ASME- } \\
\text { ICED 2006, } \\
\text { Internal } \\
\text { Combustion } \\
\text { Engine Division } \\
\text { Fall Technical } \\
\text { Conference } \\
\text { November 5-8, } \\
\text { 2006, } \\
\text { Sacramento, CA, } \\
\text { USA }\end{array}$ \\
\hline
\end{tabular}




\begin{tabular}{|c|c|c|c|c|c|c|c|c|c|c|c|}
\hline $\begin{array}{l}\text { Canola Biodiesel } \\
20 \%\end{array}$ & -- & $\begin{array}{c}0.8223 \\
\mathrm{~kg} / \mathrm{L} @ \\
15 \mathrm{C}\end{array}$ & 44 & $49 \mathrm{C}$ & -- & -- & -- & $\begin{array}{c}-24.0 \\
\mathrm{C}\end{array}$ & -- & -- & $\begin{array}{l}\text { (Girish Parvate- } \\
\text { Patil) ASME- } \\
\text { ICED 2006, } \\
\text { Internal } \\
\text { Combustion } \\
\text { Engine Division } \\
\text { Fall Technical } \\
\text { Conference } \\
\text { November 5-8, } \\
\text { 2006, } \\
\text { Sacramento, CA, } \\
\text { USA }\end{array}$ \\
\hline $\begin{array}{ll}\text { EN590 } & 15 \% \\
\text { Biodiesel } & \end{array}$ & -- & $\begin{array}{c}836 \\
\mathrm{~kg} / \mathrm{m}^{3} \\
\text { (a) } 15 \mathrm{C}\end{array}$ & 52.2 & $62 \mathrm{C}$ & -- & -- & -- & $\begin{array}{c}-36.0 \\
C\end{array}$ & -- & -- & $\begin{array}{l}\text { (A. Hull) Int. J. } \\
\text { Engine Research } \\
\text { Vol } 7 \text { (2006) } 51- \\
63\end{array}$ \\
\hline $\begin{array}{ll}\text { Mk1 } & 15 \% \\
\text { Biodiesel } & \end{array}$ & -- & $\begin{array}{c}808 \\
\mathrm{~kg} / \mathrm{m}^{3} \\
\text { (a) } 15 \mathrm{C}\end{array}$ & 51.5 & $63 \mathrm{C}$ & -- & -- & -- & $\begin{array}{c}-36.0 \\
C\end{array}$ & -- & -- & $\begin{array}{l}\text { (A.Hull) Int. J. } \\
\text { Engine Research } \\
\text { Vol } 7 \text { (2006) 51- } \\
63\end{array}$ \\
\hline Palm methyl ester & $\begin{array}{c}4.411 \\
\mathrm{cSt}\end{array}$ & -- & -- & -- & -- & -- & -- & -- & -- & -- & $\begin{array}{l}\text { (Kanit } \\
\text { Krisnangkura) } \\
\text { Fuel } 85 \quad(2006) \\
107-113 \text { Elsevier }\end{array}$ \\
\hline $\begin{array}{l}\text { Rapeseed methyl } \\
\text { ester }\end{array}$ & $\begin{array}{c}5.885 \\
\mathrm{cSt}\end{array}$ & -- & -- & -- & -- & -- & -- & -- & -- & -- & $\begin{array}{l}\text { (Kanit } \\
\text { Krisnangkura) } \\
\text { Fuel } 85 \quad(2006) \\
\text { 107-113 Elsevier }\end{array}$ \\
\hline $\begin{array}{l}\text { Soybean methyl } \\
\text { ester }\end{array}$ & $\begin{array}{l}4.005 \\
\mathrm{cSt}\end{array}$ & -- & -- & -- & -- & -- & -- & -- & -- & -- & $\begin{array}{l}\text { (Kanit } \\
\text { Krisnangkura) } \\
\text { Fuel 85 (2006) } \\
\text { 107-113 Elsevier }\end{array}$ \\
\hline
\end{tabular}




\begin{tabular}{|c|c|c|c|c|c|c|c|c|c|c|c|}
\hline $\begin{array}{l}\text { Canola methyl } \\
\text { ester }\end{array}$ & 4.229 & -- & -- & -- & -- & -- & -- & -- & -- & -- & $\begin{array}{l}\text { (Kanit } \\
\text { Krisnangkura) } \\
\text { Fuel } 85 \text { (2006) } \\
\text { 107-113 Elsevier }\end{array}$ \\
\hline $\begin{array}{l}\text { Coconut methyl } \\
\text { ester }\end{array}$ & 2.746 & -- & -- & -- & -- & -- & -- & -- & -- & -- & $\begin{array}{l}\text { (Kanit } \\
\text { Krisnangkura) } \\
\text { Fuel } 85 \text { (2006) } \\
\text { 107-113 Elsevier }\end{array}$ \\
\hline $\begin{array}{l}\text { Peanut methyl } \\
\text { eseter }\end{array}$ & 4.285 & -- & -- & - & -- & -- & -- & -- & -- & -- & $\begin{array}{l}\text { (Kanit } \\
\text { Krisnangkura) } \\
\text { Fuel } 85 \text { (2006) } \\
\text { 107-113 Elsevier }\end{array}$ \\
\hline Soy $M E$ & $\begin{array}{c}4.20 \\
\mathrm{~mm}^{2} / \mathrm{s} \\
\text { a } 40 \mathrm{C}\end{array}$ & -- & 52.70 & $\begin{array}{c}153 \\
C\end{array}$ & $\begin{array}{l}0.885 \\
\text { @ } 15.5 \\
\mathrm{C}\end{array}$ & -- & -- & $0.0 \mathrm{C}$ & -- & -- & $\begin{array}{l}\text { (R.E Tate) Fuel } \\
85 \text { (2006) 1004- } \\
1009 \text { Elsevier }\end{array}$ \\
\hline Canola ME & $\begin{array}{l}4.475 \\
\mathrm{~mm}^{2} / \mathrm{s} \\
\text { a } 40 \mathrm{C}\end{array}$ & -- & 52.90 & $\begin{array}{c}162 \\
\mathrm{C}\end{array}$ & $\begin{array}{l}0.888 \\
\text { @ } 15.5 \\
\mathrm{C}\end{array}$ & -- & -- & $\begin{array}{c}-1.0 \\
\mathrm{C}\end{array}$ & -- & -- & $\begin{array}{l}\text { (R.E Tate) Fuel } \\
85 \text { (2006) 1004- } \\
1009 \text { Elsevier }\end{array}$ \\
\hline Fish-oil EE & $\begin{array}{l}3.982 \\
\mathrm{~mm}^{2} / \mathrm{s} \\
\text { a. } 40 \mathrm{C}\end{array}$ & -- & 53.99 & $\begin{array}{c}>110 \\
\mathrm{C}\end{array}$ & $\begin{array}{l}0.878 \\
\text { (a) } 15.5 \\
\mathrm{C}\end{array}$ & -- & -- & $\begin{array}{c}-8.0 \\
\mathrm{C}\end{array}$ & -- & -- & $\begin{array}{l}\text { (R.E Tate) Fuel } \\
85 \text { (2006) 1004- } \\
1009 \text { Elsevier }\end{array}$ \\
\hline Soy $M E$ & $\begin{array}{l}4.647 \\
\mathrm{~mm}^{2} / \mathrm{s} \\
\text { a } 40 \mathrm{C}\end{array}$ & -- & -- & -- & -- & -- & -- & -- & -- & -- & $\begin{array}{l}\text { (R.E. Tate) Fuel } \\
85 \text { (2006) 1010- } \\
1015 \text { Elsevier }\end{array}$ \\
\hline Canola ME & $\begin{array}{l}4.647 \\
\mathrm{~mm}^{2} / \mathrm{s} \\
\text { a } 40 \mathrm{C}\end{array}$ & -- & -- & -- & -- & -- & -- & -- & -- & -- & $\begin{array}{l}\text { (R.E. Tate) Fuel } \\
85 \text { (2006) 1010- } \\
1015 \text { Elsevier }\end{array}$ \\
\hline Fish-oil EE & $\begin{array}{l}3.978 \\
\mathrm{~mm}^{2} / \mathrm{s} \\
\text { a. } 40 \mathrm{C}\end{array}$ & -- & -- & -- & -- & -- & -- & -- & -- & -- & $\begin{array}{l}\text { (R.E. Tate) Fuel } \\
85 \text { (2006) 1010- } \\
1015 \text { Elsevier }\end{array}$ \\
\hline
\end{tabular}




\section{DYNAMIC MODELING AND OPTIMIZATION}

A dynamic model for an internal combustion (IC) engine has been developed and the time response of micro-CHP model in TRNSYS has been investigated. In addition to the planned work, optimization of the micro-CHP system has been initiated. The research work for Fall 2007 are described as follows:

- Optimization of cost and load balancing has been performed through an energy dispatch algorithm which provides optimal solutions on decisions over whether to generate power locally or to buy power from the grid. Network flow analysis and linear programming are used to perform optimization of the micro-CHP system. This work is still in progress and is being prepared for a conference presentation. An abstract of this work has been accepted in ASME Proceedings of Energy Sustainability 2008, August 10-13, Jacksonville, FL. A linear and integer programming software CPLEX has been used to find optimal solution of a network model which resembles the MSU micro-CHP system. Since this program has limited license access, we are going to perform the simulation in MATLAB. Some work sheets are given in Appendix A.

- A dynamic internal combustion engine model for CHP applications has been developed in MathCAD. This model has been calibrated using actual measurements which were provided by Dr. Srinivasan. Furthermore comprehensive dynamic uncertainty analysis has been performed in MathCAD. The MathCAD work sheets are shown in Appendix B. We are currently preparing a journal article of this work. 


\section{Appendices}

Appendix A:

An optimal energy dispatch algorithm will be developed to minimize operational cost of micro-CHP system. This algorithm can be successfully implemented using network flow analysis and linear programming. A deterministic network model of the micro-CHP at Mississippi State University (MSU) has been developed as part of the algorithm. In the algorithm, the inputs are the cost of the electricity and fuel, and the outputs are the operational signals to the cogeneration system. In the network model, the constraints include the cooling, heating, electric load demands and the efficiencies of the CHP components. The network model and example CPLEX input sheet is attached in the appendix.

\section{Appendix B-1:}

A thermodynamic model of the SI engine has been implemented in Mathcad. The fundamental of engine simulation has been being surveyed to develop a compression ignition (CI) engine model. The closed system of finite heat release with the heat transfer was chosen and has been modeled in Mathcad based on the scope of the dynamic simulation of the micro-CHP system. This engine model provides outputs such as pressure and temperature in terms of the crank angle. The Mathcad work sheet is included in the appendix.

\section{Appendix B-2:}

Mathematical models of IC engines have been developed continually over the past century and have provided valuable contribution, e.g., it has helped to optimize design and control without conducting extensive experiments and to understand the combustion/dynamic processes as developing the formulas in the modeling. Although mathematical models of engine have been repetitively implemented and simulated on the computer, a comprehensive uncertainty analysis on the model has been rarely performed. An uncertainly analysis of the model can help to identify key controlling variables and determine uncertainty of the model. This work includes a comprehensive uncertainty analysis on the modeling of engine processes. Based on the timevarying sensitivities, upper and lower uncertainty intervals for the cylinder pressure have been obtained and plotted with the pressure curve determined from the ODE solver. The Mathcad work sheet is shown in the appendix. 


\section{Appendix A}

\section{Optimization of Micro-CHP System - Network Flow Model}

An optimal energy dispatch algorithm will be developed to minimize operational cost of micro-CHP system. This algorithm can be successfully implemented using network flow analysis and linear programming. A deterministic network model of the micro-CHP at Mississippi State University (MSU) has been developed as part of the algorithm. In the algorithm, the inputs are the cost of the electricity and fuel, and the outputs are the operational signals to the cogeneration system. In the network model, the constraints include the cooling, heating, electric load demands and the efficiencies of the CHP components. The network model is shown below.

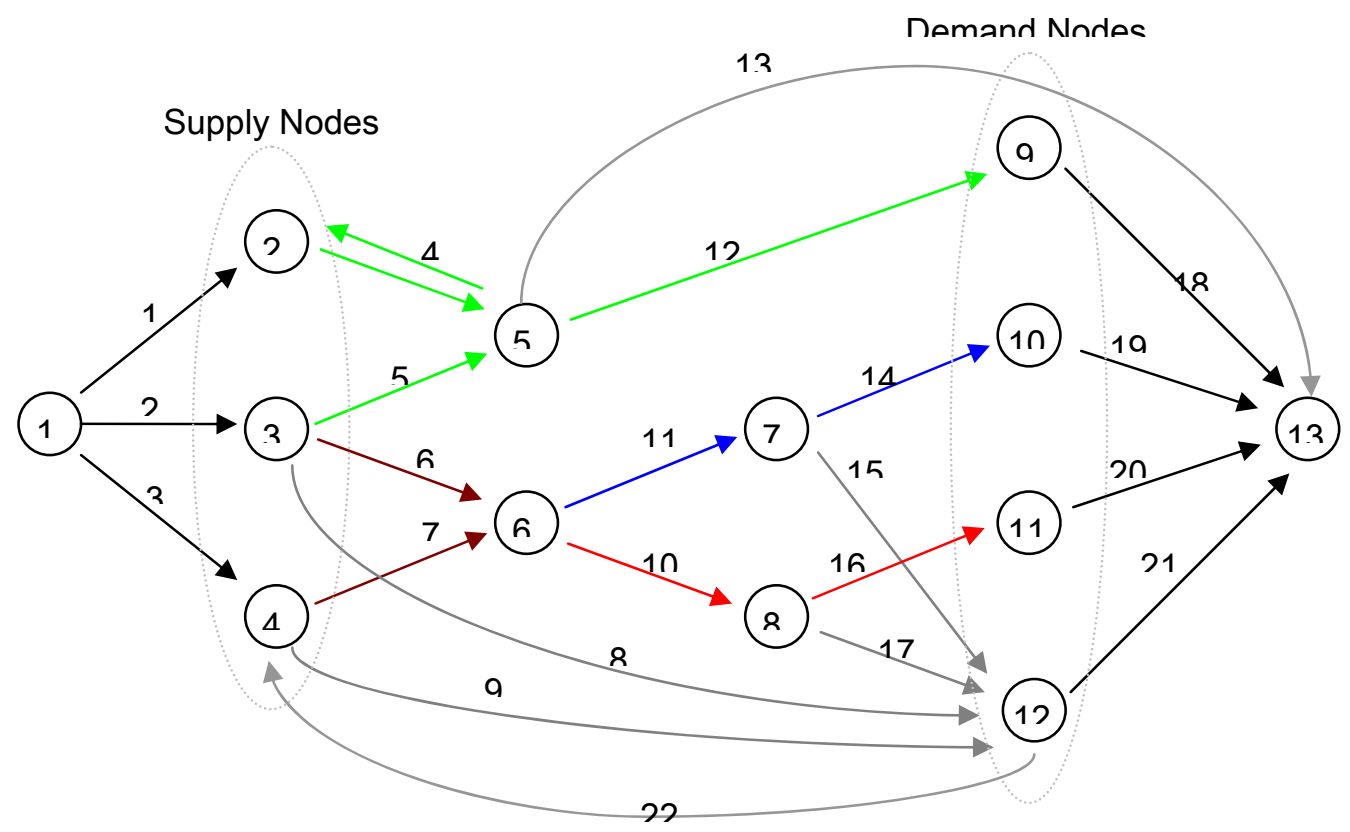

where, Node 1: Supply (Total energy or cost)

Node 2: Grid $(0.1 \$ / \mathrm{kWh}$ for electricity)

Node 3: Engine (2.80 \$/gal for diesel $12 \$ / \mathrm{ft}^{3}$ for natural gas can be converted to $\$ / \mathrm{kWh}$ )

Node 4: Boiler (12 $\$ / \mathrm{ft}^{3}$ for natural gas)

Node 5: Electrical energy (electricity) provided from engine and grid

Node 6: Thermal energy (heat) provided from engine and boiler

Node 7: Cooling equipments of micro-CHP (Energy conversion from heat energy in water to cooling energy in air)

Node 8: Heating equipments of micro-CHP (Energy conversion from heat energy in water to heat energy in air)

Node 9: Electricity demand from building

Node 10: Cooling energy demand from building

Node 11: Heating energy demand from building 
Node 12: Energy loss

Node 13: Supply (Total energy or cost)

A linear programming software CPLEX is used to obtain the optimal solution of the network flow model. An example CPLEX input sheet is shown below. Note that we are going to perform the simulation in MATLAB since this program has limited license access.

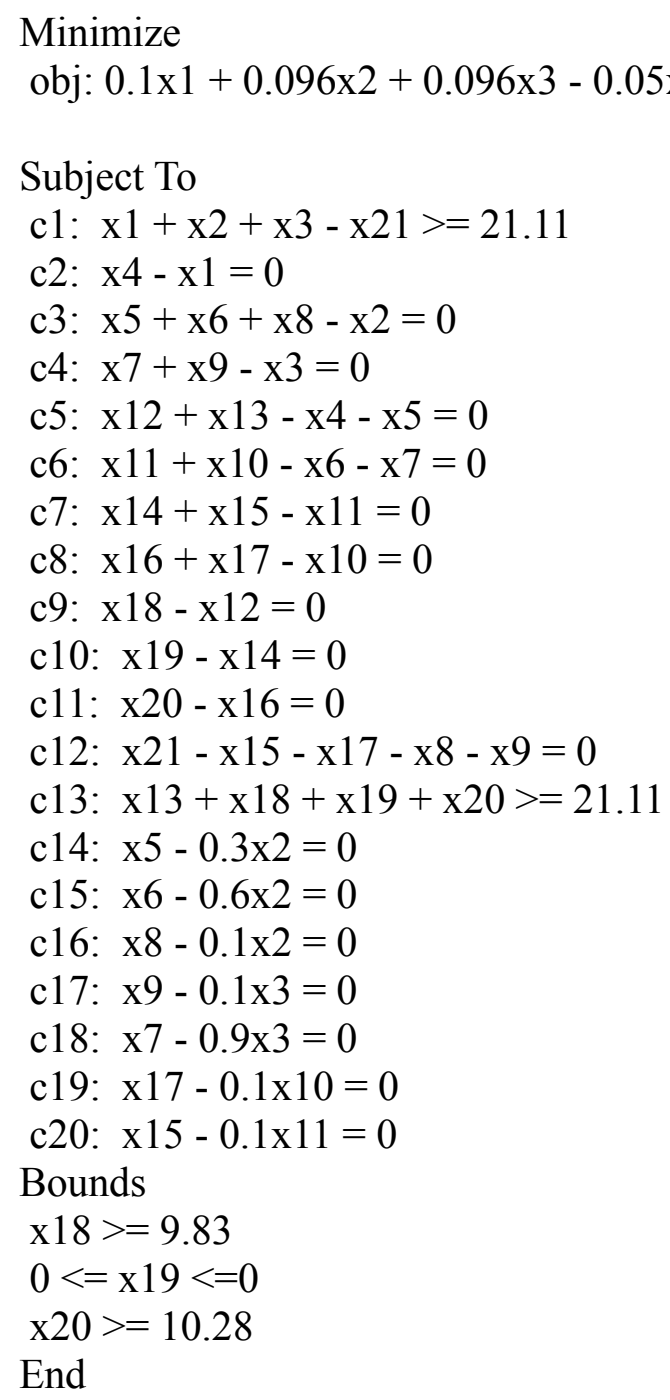


Appendix B-1

\section{Finite Heat Release Model of Dynamic Cl Engine}

Defining units

$$
\mathrm{rev}=2 \pi \cdot \mathrm{rad} \quad \mathrm{RPM}:=\frac{1}{\min } \mathrm{rev} \quad \mathrm{kmol}:=10^{3} \cdot \mathrm{mol} \quad \mathrm{kJ}:=10^{3} \cdot \mathrm{J}
$$

$\Delta$ Defining units

Importing experimental data from data.xls file

Experimental Data:

data :=

\section{data.xls}

\begin{tabular}{|c|c|c|c|}
\hline Crank angle: & $\mathrm{CA}:=$ data $^{\langle 0\rangle}-360$ & \multicolumn{2}{|c|}{$\operatorname{last}(\mathrm{CA})=223$} \\
\hline Pressure data: & $\mathrm{P}_{\mathrm{msd}}:=\operatorname{data}^{\langle 1\rangle}$ & & \\
\hline Burn fraction data: & $\mathrm{BF}:=$ data $^{\langle 2\rangle}$ & i2 := 89.. 223 & $\mathrm{BF}_{\mathrm{i} 2}:=1$ \\
\hline Heat release data: & $\mathrm{HR}:=$ data $^{\langle 3\rangle}$ & & \\
\hline Temperature data: & $\mathrm{T}_{\mathrm{msd}}:=\operatorname{data}^{\langle 4\rangle}$ & & \\
\hline
\end{tabular}

$\Delta$ Importing experimental data from data.xls file

Engine Specification

Engine speed:

$\mathrm{N}_{\mathrm{e}}:=1700 \cdot \mathrm{RPM}$

Intake pressure:

$\mathrm{P}_{1}:=1.81 \mathrm{bar}$

Intake temperature:

$\mathrm{T}_{1}:=(75+273) \mathrm{K} \quad \mathrm{T}_{1}=348 \mathrm{~K}$

Cylinder wall temperature:

$\mathrm{T}_{\mathrm{W}}:=(127+273) \mathrm{K} \quad \mathrm{T}_{\mathrm{W}}=400 \mathrm{~K}$

Compression ratio:

$\mathrm{r}_{\mathrm{C}}:=14.5$ 


\begin{tabular}{|c|c|c|}
\hline Bore of the cylinder: & $\mathrm{b}:=0.13716 \mathrm{~m}$ & \\
\hline Stroke: & $\mathrm{s}_{\mathrm{C}}:=0.1651 \mathrm{~m}$ & \\
\hline Connecting rod length: & $\mathrm{l}_{\mathrm{C}}:=0.26162 \mathrm{~m}$ & \\
\hline Injection starts: & $\theta_{\mathrm{SOI}}:=-22 \cdot \operatorname{deg}$ & \\
\hline Burn duration: & $\theta_{\mathrm{d}}:=23 \mathrm{deg}$ & \\
\hline Intake valve open: & $\theta_{\mathrm{IVO}}:=685 \cdot \operatorname{deg}$ & \\
\hline Intake valve close: & $\theta_{\mathrm{IVC}}:=217 \cdot \operatorname{deg}$ & \\
\hline Exhaust valve open: & $\theta_{\mathrm{EVO}}:=506 \cdot \mathrm{deg}$ & \\
\hline Exhaust valve close: & $\theta_{\mathrm{EVC}}:=10 \cdot \operatorname{deg}$ & \\
\hline Fuel mass flow rate: & $\mathrm{mf}_{\mathrm{dot}}:=86 \frac{\mathrm{gm}}{\mathrm{min}}$ & \\
\hline Air mass flow rate: & mair $_{\text {dot }}:=3942 \frac{\mathrm{gm}}{\mathrm{min}}$ & \\
\hline Actual air-fuel ratio: & $\mathrm{AF}_{\mathrm{a}}:=\frac{\mathrm{mair}_{\mathrm{dot}}}{\mathrm{mf}_{\mathrm{dot}}}$ & $\mathrm{AF}_{\mathrm{a}}=45.837$ \\
\hline Actual fuel-air ratio: & $\mathrm{FA}_{\mathrm{a}}:=\frac{1}{\mathrm{AF}_{\mathrm{a}}}$ & $\mathrm{FA}_{\mathrm{a}}=0.022$ \\
\hline Stoichiometric air-fuel ratio: & $\mathrm{AF}_{\mathrm{S}}:=14.4$ & \\
\hline Stoichiometric fuel-air ratio: & $\mathrm{FA}_{\mathrm{S}}:=0.0697$ & \\
\hline Equivalence ratio: & $\phi:=0.284$ & \\
\hline Lower heating value of diesel: & $\mathrm{LHV}:=42600 \cdot \frac{\mathrm{kJ}}{\mathrm{kg}}$ & \\
\hline Residual gas fraction: & $\mathrm{f}:=0.01$ & \\
\hline
\end{tabular}


Dr. Luck:

$$
\gamma 1(\mathrm{~T}):=1.43540178+\left[\left(0.0000000372954-0.00000000000351737 \cdot \frac{\mathrm{T}}{\mathrm{K}}\right) \cdot \frac{\mathrm{T}}{\mathrm{K}}-0.000129945\right] \cdot \frac{\mathrm{T}}{\mathrm{K}} \quad \gamma 1\left(\mathrm{~T}_{1}\right)=1.395
$$

Zucrow and Hoffman (from Combustion Data Acquisition and Analysis by Brown):

$$
\begin{aligned}
& \mathrm{Cp}(\mathrm{T}):=\mid \begin{array}{l}
3.6359-\frac{1.33736}{1000} \cdot \frac{\mathrm{T}}{\mathrm{K}}+\frac{3.29421}{10^{6}} \cdot\left(\frac{\mathrm{T}}{\mathrm{K}}\right)^{2}-\frac{1.91142}{10^{9}} \cdot\left(\frac{\mathrm{T}}{\mathrm{K}}\right)^{3}+\frac{0.275462}{10^{12}} \cdot\left(\frac{\mathrm{T}}{\mathrm{K}}\right)^{4} \text { if } \mathrm{T}<1000 \mathrm{~K} \\
3.04473+\frac{1.33805}{1000} \cdot \frac{\mathrm{T}}{\mathrm{K}}-\frac{0.488256}{10^{6}} \cdot\left(\frac{\mathrm{T}}{\mathrm{K}}\right)^{2}+\frac{0.0855475}{10^{9}} \cdot\left(\frac{\mathrm{T}}{\mathrm{K}}\right)^{3}-\frac{0.005701327}{10^{12}} \cdot\left(\frac{\mathrm{T}}{\mathrm{K}}\right)^{4} \text { otherwise }
\end{array} \\
& \gamma 2(\mathrm{~T}):=\frac{\mathrm{Cp}(\mathrm{T})}{\mathrm{Cp}(\mathrm{T})-1}
\end{aligned}
$$

Krieger and Borman (1986) (from SAE introduction to internal combustion engines):

$$
\begin{aligned}
& \mathrm{K}_{1}(\mathrm{~T}):=0.692 \cdot \frac{\mathrm{T}}{\mathrm{K}}+39.17 \cdot 10^{-6} \cdot\left(\frac{\mathrm{T}}{\mathrm{K}}\right)^{2}+52.9 \cdot 10^{-9} \cdot\left(\frac{\mathrm{T}}{\mathrm{K}}\right)^{3}-228.62 \cdot 10^{-13} \cdot\left(\frac{\mathrm{T}}{\mathrm{K}}\right)^{4}+277.58 \cdot 10^{-17} \cdot\left(\frac{\mathrm{T}}{\mathrm{K}}\right)^{5} \\
& \mathrm{~K}_{2}(\mathrm{~T}):=3049.33-5.7 \cdot 10^{-2} \cdot \frac{\mathrm{T}}{\mathrm{K}}-9.5 \cdot 10^{-5} \cdot\left(\frac{\mathrm{T}}{\mathrm{K}}\right)^{2}+21.53 \cdot 10^{-9} \cdot\left(\frac{\mathrm{T}}{\mathrm{K}}\right)^{3}-200.26 \cdot 10^{-14} \cdot\left(\frac{\mathrm{T}}{\mathrm{K}}\right)^{4} \\
& \mathrm{u}(\mathrm{T}):=\left(\mathrm{K}_{1}(\mathrm{~T})-\mathrm{K}_{2}(\mathrm{~T}) \cdot \phi\right) \cdot \frac{\mathrm{kJ}}{\mathrm{kg}} \quad \mathrm{R}:=(0.287+0.02 \cdot \phi) \cdot \frac{\mathrm{kJ}}{\mathrm{kg} \cdot \mathrm{K}} \\
& \mathrm{c}_{\mathrm{v}}(\mathrm{T}):=\frac{\mathrm{d}}{\mathrm{dT}} \mathrm{u}(\mathrm{T}) \quad \mathrm{c}_{\mathrm{p}}(\mathrm{T}):=\mathrm{c}_{\mathrm{v}}(\mathrm{T})+\mathrm{R} \quad \gamma 3(\mathrm{~T}):=\frac{\mathrm{c}_{\mathrm{p}}(\mathrm{T})}{\mathrm{c}_{\mathrm{v}}(\mathrm{T})}
\end{aligned}
$$

Heejin:

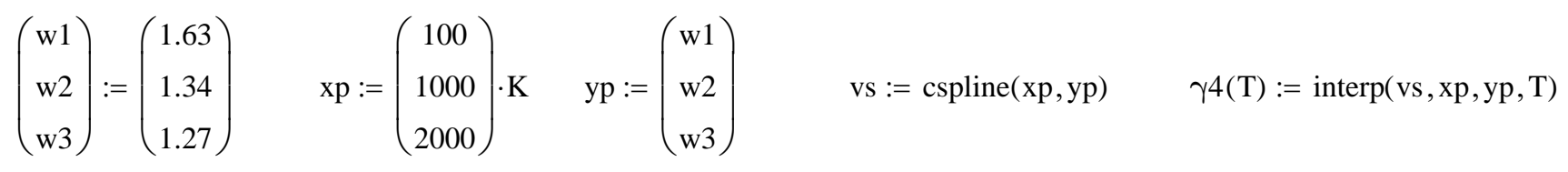


$\gamma(\mathrm{T}, \mathrm{w} 1, \mathrm{w} 2, \mathrm{w} 3):=$ interp $\left[\right.$ cspline $\left.\left[\mathrm{xp},\left(\begin{array}{c}\mathrm{w} 1 \\ \mathrm{w} 2 \\ \mathrm{w} 3\end{array}\right)\right], \mathrm{xp},\left(\begin{array}{c}\mathrm{w} 1 \\ \mathrm{w} 2 \\ \mathrm{w} 3\end{array}\right), \mathrm{T}\right] \quad \gamma(\mathrm{T}):=\gamma(\mathrm{T}, \mathrm{w1}, \mathrm{w} 2, \mathrm{w} 3)$

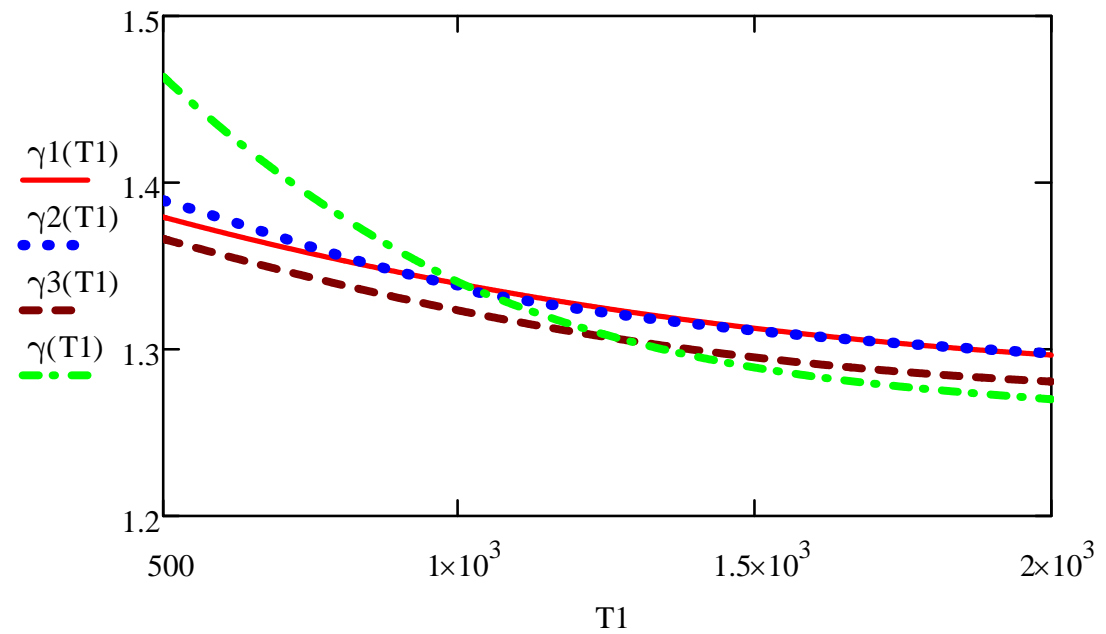

$\lambda(T):=\gamma 1(T)$ 
- The rate of cylinder volume is

$$
\begin{aligned}
& \mathrm{V}_{\mathrm{d}}:=\frac{\pi}{4} \cdot \mathrm{b}^{2} \cdot \mathrm{s}_{\mathrm{C}} \quad \mathrm{V}_{\mathrm{d}}=2.439 \mathrm{~L} \quad \text { : displacement volume } \\
& \mathrm{V}_{1}:=\frac{\mathrm{r}_{\mathrm{c}} \cdot \mathrm{V}_{\mathrm{d}}}{\mathrm{r}_{\mathrm{C}}-1} \quad \mathrm{~V}_{1}=2.62 \mathrm{~L} \quad \text { : volume of cylinder at BDC } \\
& \mathrm{V}_{\mathrm{C}}:=\mathrm{V}_{1}-\mathrm{V}_{\mathrm{d}} \quad \mathrm{V}_{\mathrm{C}}=0.181 \mathrm{~L} \quad \text { : volume of cylinder at TDC } \\
& \mathrm{a}_{\mathrm{C}}:=\frac{\mathrm{s}_{\mathrm{C}}}{2} \quad \mathrm{a}_{\mathrm{C}}=0.083 \mathrm{~m} \quad \text { : crank radius } \\
& \mathrm{y}(\theta):=\mathrm{a}_{\mathrm{C}}+\mathrm{l}_{\mathrm{C}}-\left[\left(\mathrm{l}_{\mathrm{C}}{ }^{2}-\mathrm{a}_{\mathrm{C}}{ }^{2} \cdot \sin (\theta)^{2}\right)^{0.5}+\mathrm{a}_{\mathrm{C}} \cdot \cos (\theta)\right] \quad \text { : instantaneous stroke } \\
& \mathrm{V}(\theta):=\frac{\mathrm{V}_{\mathrm{d}}}{\mathrm{r}_{\mathrm{C}}-1}+\frac{\mathrm{V}_{\mathrm{d}}}{\mathrm{s}_{\mathrm{C}}} \cdot \mathrm{y}(\theta) \\
& \operatorname{dVd} \theta(\theta):=\frac{V_{d}}{2} \cdot \sin (\theta) \cdot\left[1+a_{c} \cdot \cos (\theta) \cdot\left(l_{c}{ }^{2}-a_{C}{ }^{2} \cdot \sin (\theta)^{2}\right)^{-0.5}\right]
\end{aligned}
$$

- The mean piston speed is

$$
\text { Upbar }:=2 \cdot \mathrm{N}_{\mathrm{e}} \cdot \mathrm{s}_{\mathrm{C}} \quad \text { Upbar }=9.356 \frac{\mathrm{m}}{\mathrm{s}}
$$


- A correlation for ignition delay developed by Hardenberg and Hase (1979) is described as

$$
\mathrm{R}_{\text {univ }}:=8.3143 \frac{\mathrm{J}}{\mathrm{mol} \cdot \mathrm{K}} \quad: \text { Universal gas constant }
$$

$\mathrm{CN}:=45 \quad$ : Cetane number $(\mathrm{CN})$ is a measure of the ignition quality of diesel fuel via the $\mathrm{Cl}$ process. Low cetane fuels increase engine deposits resulting in more smoke, increased exhaust emissions and greater engine wear. In North America, diesel at the pump can be found in two $\mathrm{CN}$ ranges: 40-46 for regular diesel, and 45-50 for premium.

$\mathrm{E}_{\mathrm{a}}:=\frac{618840}{\mathrm{CN}+25} \cdot \frac{\mathrm{J}}{\mathrm{mol}} \quad:$ An apparent activation energy for the fuel autoignition process.

$\mathrm{r}_{\mathrm{i}}:=\frac{\mathrm{V}\left(\theta_{\mathrm{IVC}}\right)-\mathrm{V}\left(\theta_{\mathrm{SOI}}\right)}{\mathrm{V}_{\mathrm{C}}} \quad \mathrm{r}_{\mathrm{i}}=11.889 \quad$ : Volumetric compression ratio from IVC to SOI

$$
\mathrm{T}_{\mathrm{i}}:=\mathrm{T}_{1} \cdot \mathrm{r}_{\mathrm{i}} \gamma\left(\mathrm{T}_{1}\right)-1 \quad \mathrm{P}_{\mathrm{i}}:=\mathrm{P}_{1} \cdot \mathrm{r}_{\mathrm{i}} \gamma\left(\mathrm{T}_{1}\right) \quad \text { : Temperature and pressure at IVC }
$$$$
\theta_{\text {id }}:=\left(0.36+0.22 \cdot \frac{\mathrm{Upbar}}{\frac{\mathrm{m}}{\mathrm{s}}}\right) \cdot \exp \left[\left(\mathrm{E}_{\mathrm{a}} \cdot \frac{1}{\mathrm{R}_{\mathrm{univ}} \cdot \mathrm{T}_{\mathrm{i}}}-\frac{1}{17190}\right) \cdot\left(\frac{21.2}{\frac{\mathrm{P}_{\mathrm{i}}}{\mathrm{bar}}-12.4}\right)^{0.63}\right] \cdot \mathrm{deg}
$$

$$
\theta_{\text {id }}=4.961 \cdot \operatorname{deg} \quad t_{i d}:=\frac{\theta_{\text {id }}}{\mathrm{N}_{\mathrm{e}} \cdot 2 \pi} \quad t_{\mathrm{id}}=0.486 \cdot \mathrm{ms}
$$


- Weibe function represent the typical cumulative heat release or "burn fraction" curve for a $\mathrm{Cl}$ engine.

Finding the values of $a$ and $n$ for Weibe function by minimizing error:

$\mathrm{a}:=2 \quad \mathrm{n}:=1 \quad$ Initial guesses

$\mathrm{x}_{\mathrm{b}}(\theta, \mathrm{a}, \mathrm{n}):=1-\exp \left[-\mathrm{a} \cdot\left[\frac{\theta-\left(\theta_{\mathrm{SOI}}+\theta_{\mathrm{id}}\right)}{\theta_{\mathrm{d}}}\right]^{\mathrm{n}+1}\right]$

$\mathrm{x}_{\mathrm{b} \_ \text {min }}(\mathrm{a}, \mathrm{n}):=\mathrm{BF}-\overrightarrow{\mathrm{x}_{\mathrm{b}}(\mathrm{CA}, \mathrm{a}, \mathrm{n})}$

$\operatorname{SSE}(\mathrm{a}, \mathrm{n}):=\sum \mathrm{x}_{\mathrm{b} \_\min }(\mathrm{a}, \mathrm{n})^{2}$

$\left(\begin{array}{c}\mathrm{a} \\ \mathrm{m} \\ \mathrm{n}\end{array}\right):=\operatorname{Minimize}(\operatorname{SSE}, \mathrm{a}, \mathrm{n}) \quad\left(\begin{array}{l}\mathrm{a} \\ \mathrm{n}\end{array}\right)=\left(\begin{array}{c}1.832 \\ 1\end{array}\right)$

$\mathrm{x}_{\mathrm{bal}}(\theta):=\mid \begin{aligned} & \mathrm{x}_{\mathrm{b}}(\theta, \mathrm{a}, \mathrm{n}) \text { if } \theta \geq \theta_{\mathrm{SOI}}+\theta_{\mathrm{id}} \\ & 0 \text { otherwise }\end{aligned}$

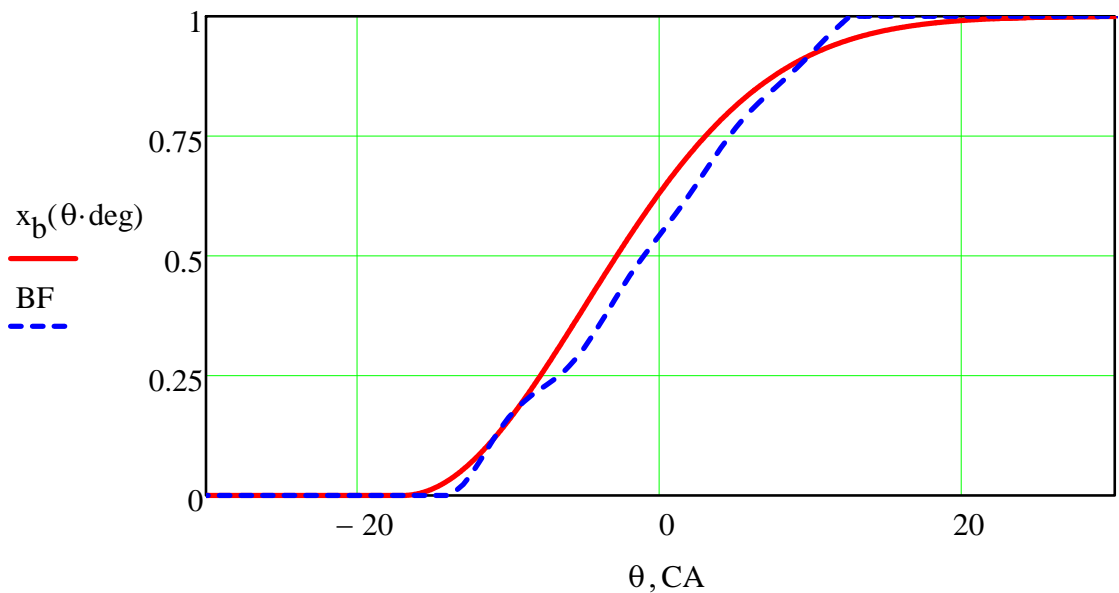


- The rate of heat release as a function of crank angle is obtained as

$$
\begin{aligned}
& \frac{d}{d \theta} Q_{C}=Q_{i n} \cdot\left(\frac{d}{d \theta} x_{b}\right)=(n+1) \cdot a \cdot \frac{Q_{i n}}{\theta_{d}} \cdot\left(1-x_{b}\right) \cdot\left[\frac{\theta-\left(\theta_{\text {SOI }}+\theta_{i d}\right)}{\theta_{d}}\right]^{n} \\
& \text { dxb_d } \theta(\theta):=\frac{(\mathrm{n}+1) \cdot \mathrm{a}}{\theta_{\mathrm{d}}} \cdot\left(1-\mathrm{x}_{\mathrm{b}}(\theta)\right) \cdot\left[\frac{\theta-\left(\theta_{\text {SOI }}+\theta_{\mathrm{id}}\right)}{\theta_{\mathrm{d}}}\right]^{\mathrm{n}} \quad \text { Checking: } \quad \int_{\theta_{\text {SOI }^{+}} \theta_{\text {id }}}^{30 \mathrm{deg}} \mathrm{dxb} \_\mathrm{d} \theta(\theta) \mathrm{d} \theta=1 \\
& \mathrm{~m}_{1}:=\frac{\mathrm{P}_{1} \cdot \mathrm{V}_{1}}{\mathrm{R} \cdot \mathrm{T}_{1}} \quad \mathrm{~m}_{\mathrm{f}}:=\frac{\mathrm{mf}_{\mathrm{dot}}}{\mathrm{N}_{\mathrm{e}}} \quad \mathrm{m}_{\mathrm{f}}=5.059 \times 10^{-5} \mathrm{~kg} \\
& \mathrm{q}_{\mathrm{in}}:=\mid \begin{array}{l}
\frac{\phi \cdot \mathrm{FA}_{\mathrm{S}}}{1+\phi \cdot \mathrm{FA}_{\mathrm{S}}} \cdot \mathrm{LHV} \text { if } \phi \leq 1 \\
\frac{\phi \cdot \mathrm{FA}_{\mathrm{S}}}{1+\phi \cdot \mathrm{FA}_{\mathrm{S}}} \cdot\left[\mathrm{LHV}-3890(\phi-1) \cdot \frac{\mathrm{kJ}}{\mathrm{kg}}\right] \text { otherwise }
\end{array} \\
& \mathrm{Q}_{\mathrm{in}}:=\mathrm{m}_{1} \cdot(1-\mathrm{f}) \cdot \mathrm{q}_{\mathrm{in}} \quad \mathrm{Q}_{\mathrm{in}}=3.812 \cdot \mathrm{kJ} \quad \mathrm{Q}_{\mathrm{in}}:=\mathrm{m}_{\mathrm{f}} \cdot \mathrm{LHV} \cdot 2 \quad \mathrm{Q}_{\mathrm{in}}=4.31 \cdot \mathrm{kJ} \\
& \text { dQc_d } \theta(\theta):=\mid \begin{array}{l}
\mathrm{Q}_{\text {in }} \cdot \mathrm{dxb} \_\mathrm{d} \theta(\theta) \\
0 \text { otherwise }
\end{array} \text { if } \theta \geq \theta_{\text {SOI }}+\theta_{\text {id }} \quad \text { Checking: } \int_{\theta_{\text {SOI }}+\theta_{\text {id }}}^{30 \mathrm{deg}} \text { dQc_d } \theta(\theta) \mathrm{d} \theta=3.81 \cdot \mathrm{kJ}
\end{aligned}
$$

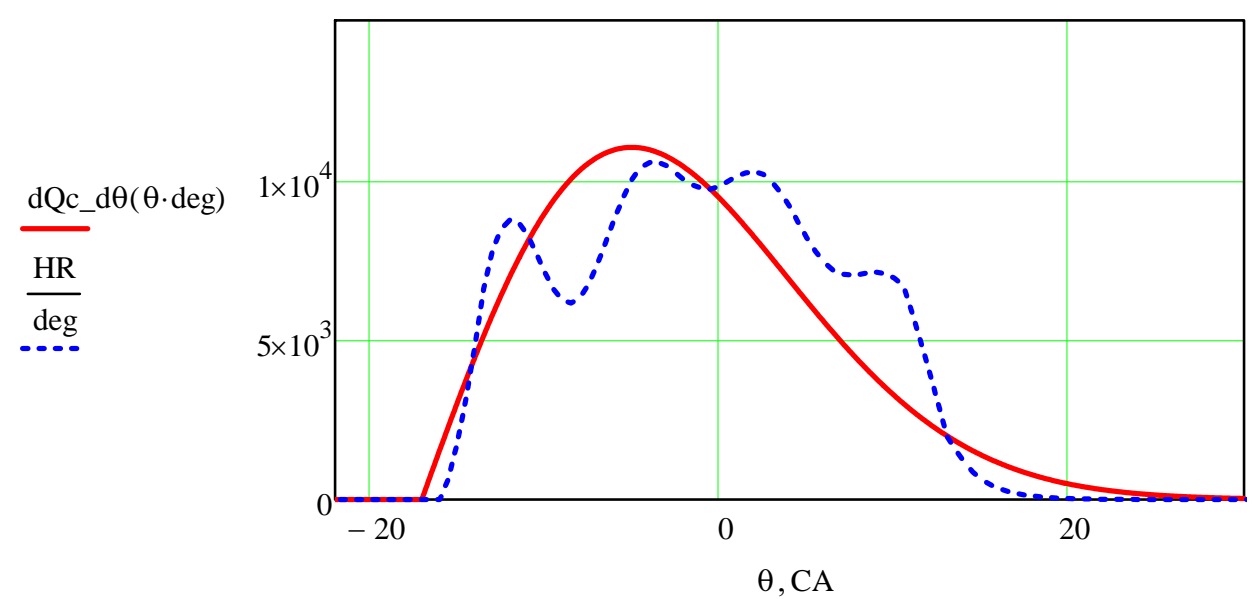


- Watson et al (1981) provide mass fraction burned equation as follows:

Diesel combustion can be divided into two parts: the pre-mixed burning phase and the diffusion burning phase. The pre-mixed phase is a consequence of the mixture prepared during the ignition delay period burning rapidly; the diffusion burning phase accounts for the remainder of combustion.

$$
\begin{aligned}
& \mathrm{KMN}_{\mathrm{N}}:=2+1.25 \cdot 10^{-8} \cdot\left(\theta_{\mathrm{id}}\right)^{2.4} \quad \mathrm{~K}_{2 \mathrm{~N}}:=5000 \quad \mathrm{~K}_{3}:=\frac{14.2}{\phi^{0.644}} \quad \mathrm{~K}_{4}:=0.79 \cdot \mathrm{K}_{3}^{0.25} \\
& \mathrm{f}_{1}(\mathrm{t}):=1-\left(1-\mathrm{t}^{\mathrm{K}_{1}}\right)^{\mathrm{K}_{2}} \quad \text { : pre-mixed burning function } \\
& \mathrm{f}_{\mathrm{A}}(\mathrm{t}):=1-\left[1-\left(\frac{\mathrm{t}}{2}\right)^{\mathrm{K}_{1}}\right]^{\mathrm{K}_{2}} \\
& \mathrm{f}_{2}(\mathrm{t}):=1-\exp \left(-\mathrm{K}_{3} \cdot \mathrm{t} \mathrm{K}_{4}\right) \quad: \text { diffusion burning function } \\
& \mathrm{f}_{22}(\mathrm{t}):=1-\exp \left[-\mathrm{K}_{3} \cdot\left(\frac{\mathrm{t}}{2}\right)^{\mathrm{K}_{4}}\right] \\
& \text { aa }:=0.95 \quad \text { bb }:=0.25 \quad \text { cc }:=0.45 \\
& \beta:=1-\frac{\mathrm{aa} \cdot \phi^{\mathrm{bb}}}{\left(\frac{\mathrm{t}_{\mathrm{id}}}{\mathrm{ms}}\right)^{\mathrm{cc}}} \quad: \text { fraction of fuel burned in the pre-mixed phase } \\
& \operatorname{mfb}(\theta):=\beta \cdot \mathrm{f}_{1}\left[\theta-\left(\theta_{\mathrm{SOI}}+\theta_{\mathrm{id}}\right)\right]+(1-\beta) \cdot \mathrm{f}_{2}\left[\theta-\left(\theta_{\mathrm{SOI}}+\theta_{\mathrm{id}}\right)\right] \\
& \operatorname{dmfb} \_d t(\theta):=Q_{i n} \cdot \frac{d}{d \theta} \operatorname{mfb}(\theta)
\end{aligned}
$$

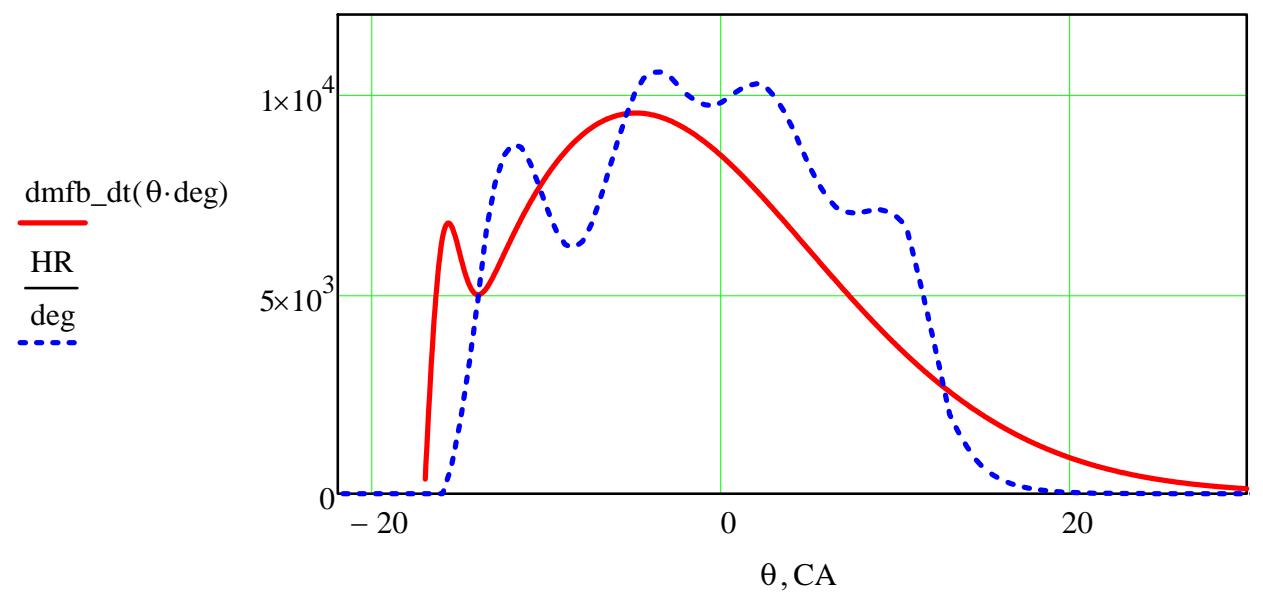


- The rate of heat transfer between the cylinder wall and gas is defined using Woschni's expression.

$$
\begin{aligned}
& \mathrm{R}:=(0.287+0.02 \cdot \phi) \cdot \frac{\mathrm{kJ}}{\mathrm{kg} \cdot \mathrm{K}} \quad: \text { gas constant } \\
& \mathrm{m}_{1 \mathrm{~N}}:=\frac{\mathrm{P}_{1} \cdot \mathrm{V}_{1}}{\mathrm{R} \cdot \mathrm{T}_{1}} \quad \mathrm{~m}_{1}=4.656 \times 10^{-3} \mathrm{~kg} \\
& \mathrm{~T}(\theta, \mathrm{P}):=\frac{\mathrm{P} \cdot \mathrm{kPa} \cdot \mathrm{V}(\theta)}{\mathrm{m}_{1} \cdot \mathrm{R}} \quad \text { : gas temperature in terms of } \theta \text { and } \mathrm{P} \\
& \mathrm{P}_{\mathrm{m}}(\theta, \mathrm{P}):=\mathrm{P}_{1} \cdot\left(\frac{\mathrm{V}_{1}}{\mathrm{~V}(\theta)}\right)^{\gamma(\mathrm{T}(\theta, \mathrm{P}))} \quad: \text { motored cylinder pressure } \\
& \mathrm{C}_{1}:=2.28 \quad \mathrm{C}_{2}:=3.24 \cdot 10^{-3} \\
& \mathrm{U}(\theta, \mathrm{P}):=\mid \begin{array}{l}
\mathrm{C}_{1} \cdot \text { Upbar }+\mathrm{C}_{2}\left(\frac{\mathrm{m}}{\mathrm{sec} \cdot \mathrm{K}}\right) \cdot \mathrm{T}_{1} \cdot \frac{\mathrm{V}_{\mathrm{d}}}{\mathrm{V}_{1} \cdot \mathrm{P}_{1}} \cdot\left(\mathrm{P}_{1}-\mathrm{P}_{\mathrm{m}}(\theta, \mathrm{P})\right) \text { if } \theta_{\mathrm{SOI}}<\theta<30 \mathrm{deg}: \text { average cylinder gas velocity } \\
\mathrm{C}_{1} \cdot \text { Upbar otherwise }
\end{array} \\
& \mathrm{h}_{\mathrm{g}}(\theta, \mathrm{P}):=3.26 \cdot \mathrm{P}^{0.8} \cdot\left(\left|\mathrm{U}(\theta, \mathrm{P}) \cdot \frac{\mathrm{sec}}{\mathrm{m}}\right|\right)^{0.8} \cdot\left(\mathrm{b} \cdot \frac{1}{\mathrm{~m}}\right)^{-0.2} \cdot\left(\mathrm{T}(\theta, \mathrm{P}) \cdot \frac{1}{\mathrm{~K}}\right)^{-0.55} \cdot \frac{\mathrm{W}}{\mathrm{m}^{2} \cdot \mathrm{K}} \quad \text { : convective heat transfer coefficient } \\
& \mathrm{A}_{\mathrm{w}}(\theta):=\pi \cdot \mathrm{b} \cdot \mathrm{y}(\theta)+\frac{\pi}{2} \cdot \mathrm{b}^{2} \quad \text { : exposed cylinder area } \\
& \operatorname{dQhtd} \theta(\theta, P):=\frac{h_{g}(\theta, P) \cdot A_{w}(\theta) \cdot\left(T(\theta, P)-T_{w}\right)}{N_{e}}
\end{aligned}
$$


- The closed-system differential energy equation is

$$
\begin{aligned}
& \delta \mathrm{Q}-\delta \mathrm{W}=\mathrm{dU} \\
& \delta \mathrm{Q}-\mathrm{PdV}=\mathrm{m} \cdot \mathrm{c}_{\mathrm{V}} \cdot \mathrm{dT} \quad<=\quad \mathrm{P} \cdot \mathrm{V}=\mathrm{m} \cdot \mathrm{R} \cdot \mathrm{T}, \quad \mathrm{m} \cdot \mathrm{dT}=\frac{1}{\mathrm{R}} \cdot(\mathrm{P} \cdot \mathrm{dV}+\mathrm{V} \cdot \mathrm{dP}) \\
& \delta \mathrm{Q}-\mathrm{PdV}=\frac{\mathrm{C}_{\mathrm{V}}}{\mathrm{R}} \cdot(\mathrm{P} \cdot \mathrm{dV}+\mathrm{V} \cdot \mathrm{dP}) \\
& \frac{\mathrm{d}}{\mathrm{d} \theta} \mathrm{Q}-\mathrm{P} \cdot \frac{\mathrm{d}}{\mathrm{d} \theta} \mathrm{V}=\frac{\mathrm{C}_{\mathrm{V}}}{\mathrm{R}} \cdot\left(\mathrm{P} \cdot \frac{\mathrm{d}}{\mathrm{d} \theta} \mathrm{V}+\mathrm{V} \cdot \frac{\mathrm{d}}{\mathrm{d} \theta} \mathrm{P}\right) \quad<=\quad \mathrm{Q}=\mathrm{Q}_{\mathrm{C}}-\mathrm{Q}_{\mathrm{HT}} \\
& \frac{\mathrm{d}}{\mathrm{d} \theta} \mathrm{P}=-\gamma \cdot \frac{\mathrm{P}}{\mathrm{V}} \cdot \frac{\mathrm{d}}{\mathrm{d} \theta} \mathrm{V}+\frac{\gamma-1}{\mathrm{~V}} \cdot\left(\frac{\mathrm{d}}{\mathrm{d} \theta} \mathrm{Q}_{\mathrm{C}}-\frac{\mathrm{d}}{\mathrm{d} \theta} \mathrm{Q}_{\mathrm{HT}}\right)
\end{aligned}
$$

- The energy equation is

$$
\begin{aligned}
& \operatorname{dPd} \theta(\theta, \mathrm{P}):=-\gamma(\mathrm{T}(\theta, \mathrm{P})) \cdot \frac{\mathrm{P}}{\mathrm{V}(\theta)} \cdot \mathrm{dVd} \theta(\theta)+\frac{\gamma(\mathrm{T}(\theta, \mathrm{P}))-1}{\mathrm{~V}(\theta)} \cdot\left(\mathrm{dQc} \_\mathrm{d} \theta(\theta)\right) \cdot \frac{1}{\mathrm{kPa}} \\
& \operatorname{dPd} \theta w H T(\theta, \mathrm{P}):=-\gamma(\mathrm{T}(\theta, \mathrm{P})) \cdot \frac{\mathrm{P}}{\mathrm{V}(\theta)} \cdot \operatorname{dVd} \theta(\theta)+\frac{\gamma(\mathrm{T}(\theta, \mathrm{P}))-1}{\mathrm{~V}(\theta)} \cdot\left(\mathrm{dQ} \_\_d \theta(\theta)\right) \cdot \frac{1}{\mathrm{kPa}}-\left(\frac{\gamma(\mathrm{T}(\theta, \mathrm{P}))-1}{\mathrm{~V}(\theta)}\right) \cdot \mathrm{dQhtd} \theta(\theta, \mathrm{P}) \cdot \frac{1}{\mathrm{kPa}}
\end{aligned}
$$

- The energy equations can be solved using the fourth order Runge-Kutta method ( rkfixed in Mathcad).

$$
\begin{aligned}
& \text { Soln }:=\operatorname{rkfixed}\left(\frac{\mathrm{P}_{1}}{\mathrm{kPa}},-180 \mathrm{deg}, 180 \mathrm{deg}, 360, \mathrm{dPd} \theta\right) \quad \text { SolnwHT }:=\operatorname{rkfixed}\left(\frac{\mathrm{P}_{1}}{\mathrm{kPa}},-180 \mathrm{deg}, 180 \mathrm{deg}, 360, \mathrm{dPd} \theta \mathrm{wHT}\right) \\
& \theta_{1}:=\operatorname{Soln}^{\langle 0\rangle} \cdot \frac{360}{2 \pi} \quad \mathrm{P}:=\operatorname{Soln}^{\langle{ }{ }\rangle} \cdot \mathrm{kPa} \quad \max (\mathrm{P})=121.833 \cdot \mathrm{bar} \\
& \theta_{2}:=\text { SolnwHT }^{\langle 0\rangle} \cdot \frac{360}{2 \pi} \quad \text { PwHT }:=\text { SolnwHT }^{\langle 1\rangle} \cdot \mathrm{kPa} \quad \max (\mathrm{PwHT})=114.082 \cdot \mathrm{bar} \\
& \mathrm{i}:=0 \ldots \operatorname{last}(\mathrm{P}) \quad \mathrm{T}_{\mathrm{w} \dot{\mathrm{i}}}:=\frac{\mathrm{P}_{\mathrm{i}} \cdot \mathrm{V}\left(\theta_{\left.1_{\mathrm{i}} \mathrm{deg}\right)}\right.}{\mathrm{m}_{1} \cdot \mathrm{R}} \quad \mathrm{TwHT}_{\mathrm{i}}:=\frac{\mathrm{PwHT}_{\mathrm{i}} \cdot \mathrm{V}\left(\theta_{\left.2_{\mathrm{i}} \mathrm{deg}\right)}\right.}{\mathrm{m}_{1} \cdot \mathrm{R}}
\end{aligned}
$$


- The cylinder gas pressure and temperature profiles are shown below. The effect of heat transfer on cylinder gas pressure and temperature is also included in the figures.
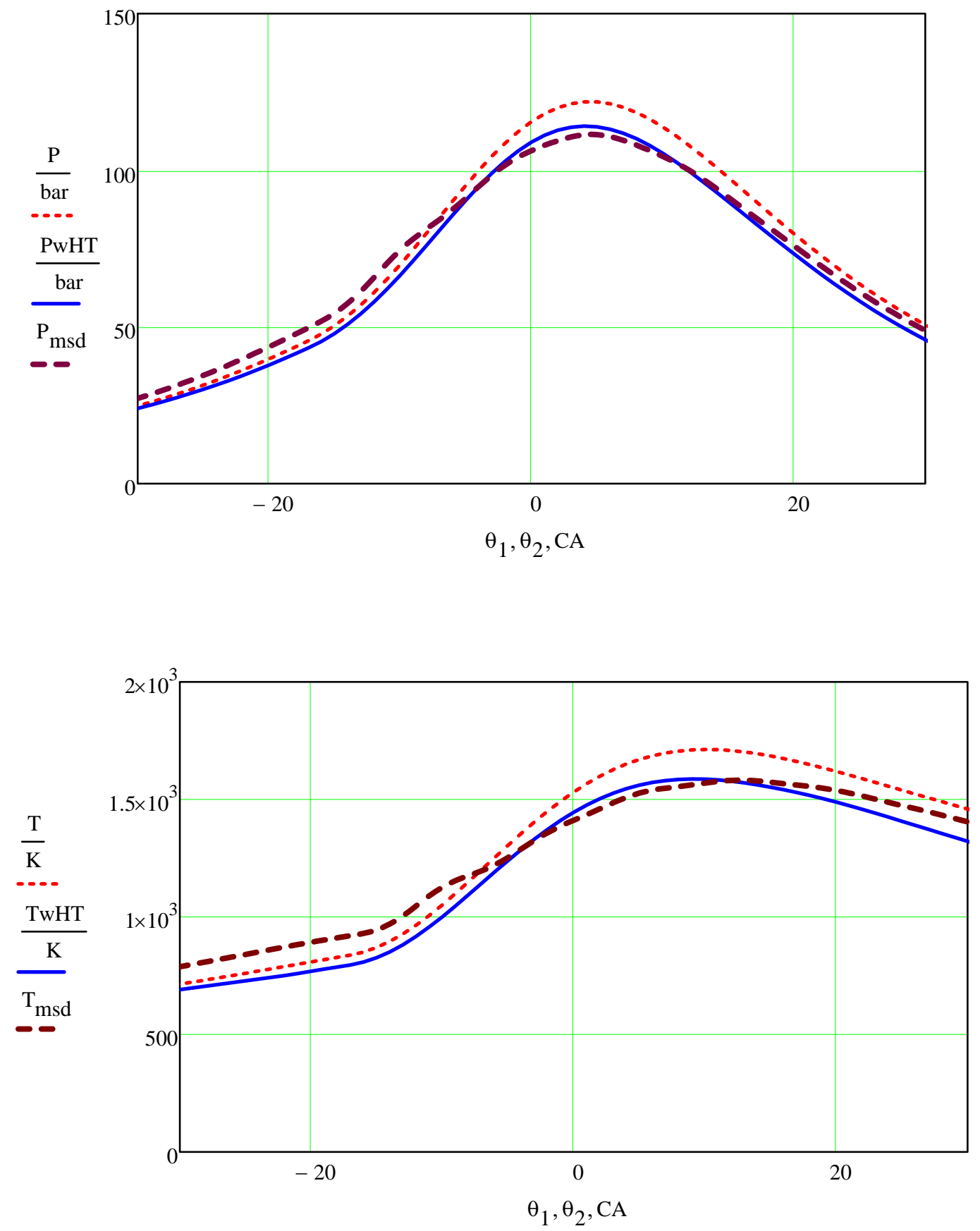
Appendix B-2

\section{Uncertainty Analysis on Dynamic CI Engine}

Importing experimental data from data.xls file

Experimental Data:

data $:=$

\section{data.xls}

\begin{tabular}{|c|c|c|c|}
\hline Crank angle: & $\mathrm{CA}:=\operatorname{data}^{\langle 0\rangle}-360$ & & 223 \\
\hline Pressure data: & $\mathrm{P}_{\mathrm{msd}}:=$ data $^{\langle 1\rangle}$ & & \\
\hline Burn fraction data: & $\mathrm{BF}:=$ data $^{\langle 2\rangle}$ & i2 := 89 .. 223 & $\mathrm{BF}_{\mathrm{i} 2}:=1$ \\
\hline Heat release data: & $\mathrm{HR}:=$ data $^{\langle 3\rangle}$ & & \\
\hline Temperature data: & $\mathrm{T}_{\mathrm{msd}}:=$ data $^{\langle 4\rangle}$ & & \\
\hline
\end{tabular}

Amporting experimental data from data.xls file

$\mathrm{RPM}:=\frac{1}{\min }$ rev $\quad \mathrm{kmol}:=10^{3} \cdot \mathrm{mol} \quad \mathrm{kJ}:=10^{3} \cdot \mathrm{J}$

Engine speed:

Intake pressure:

Intake temperature:

Cylinder wall temperature:

Compression ratio:

Bore of the cylinder:

Stroke:

Connecting rod length:
$\mathrm{N}_{\mathrm{e}}:=\frac{1700}{60}$

$\mathrm{P}_{1}:=181$

$\mathrm{T}_{1}:=(75+273)$

$\mathrm{T}_{1}=348$

$\mathrm{T}_{\mathrm{W}}:=(127+273)$

$\mathrm{T}_{\mathrm{W}}=400$

$\mathrm{r}_{\mathrm{C}}:=14.5$

$\mathrm{b}:=0.13716$

$\mathrm{s}_{\mathrm{C}}:=0.1651$

$\mathrm{l}_{\mathrm{C}}:=0.26162$ 


$$
\begin{aligned}
& \text { Injection starts: } \quad \theta_{\mathrm{SOI}}:=-22 \cdot \operatorname{deg} \\
& \text { Burn duration: } \quad \theta_{\mathrm{d}}:=23 \mathrm{deg} \\
& \text { Intake valve open: } \quad \theta_{\mathrm{IVO}}:=685 \cdot \mathrm{deg} \\
& \text { Intake valve close: } \quad \theta_{\mathrm{IVC}}:=217 \cdot \mathrm{deg} \\
& \text { Exhaust valve open: } \quad \theta_{\mathrm{EVO}}:=506 \cdot \operatorname{deg} \\
& \text { Exhaust valve close: } \quad \theta_{\mathrm{EVC}}:=10 \cdot \mathrm{deg} \\
& \text { Fuel mass flow rate: } \quad \operatorname{mf}_{\text {dot }}:=0.00143 \\
& \text { Air mass flow rate: } \quad \text { mair }_{\text {dot }}:=0.0657 \\
& \text { Actual air-fuel ratio: } \quad \mathrm{AF}_{\mathrm{a}}:=\frac{\mathrm{mair}_{\mathrm{dot}}}{\mathrm{mf}_{\mathrm{dot}}} \quad \mathrm{AF}_{\mathrm{a}}=45.944 \\
& \text { Actual fuel-air ratio: } \quad \mathrm{FA}_{\mathrm{a}}:=\frac{1}{\mathrm{AF}_{\mathrm{a}}} \quad \mathrm{FA}_{\mathrm{a}}=0.022 \\
& \text { Stoichiometric air-fuel ratio: } \quad \mathrm{AF}_{\mathrm{S}}:=14.4 \\
& \text { Stoichiometric fuel-air ratio: } \quad \mathrm{FA}_{\mathrm{S}}:=0.0697 \\
& \text { Equivalence ratio: } \quad \phi:=\frac{\mathrm{FA}_{\mathrm{a}}}{\mathrm{FA}_{\mathrm{S}}} \quad \phi=0.312 \\
& \text { Lower heating value of diesel: } \quad \text { LHV }:=42600 \\
& \text { Residual gas fraction: } \quad \mathrm{f}:=0.01 \\
& \text { Universal gas constant: } \quad \mathrm{R}_{\mathrm{univ}}:=8.3143 \\
& \text { Activation energy: } \quad \mathrm{E}_{\mathrm{a}}:=8840.571 \\
& \text { Weibe function coefficients: } \quad \mathrm{a}:=1.832 \quad \mathrm{n}:=1 \\
& \text { Coefficients for specific heat ratio: } \left.\quad \text { xp }:=\left(\begin{array}{c}
500 \\
1000 \\
2000
\end{array}\right) \quad \text { yp :=( } \begin{array}{c}
1.389 \\
1.336 \\
1.298
\end{array}\right)
\end{aligned}
$$


Nominal values for each variables:

$$
\mathrm{z}:=\left(\begin{array}{c}
\mathrm{P}_{1} \\
\mathrm{~N}_{\mathrm{e}} \\
\mathrm{T}_{\mathrm{W}} \\
\mathrm{r}_{\mathrm{C}} \\
\theta_{\mathrm{SOI}} \\
\theta_{\mathrm{d}} \\
\theta_{\mathrm{IVC}} \\
\mathrm{mf}_{\mathrm{dot}} \\
\mathrm{mair}_{\mathrm{dot}} \\
\mathrm{FA}_{\mathrm{S}} \\
\mathrm{LHV} \\
\mathrm{a} \\
\mathrm{n} \\
\mathrm{P}_{1} \\
\mathrm{~T}_{1} \\
\mathrm{~b} \\
\mathrm{~s}_{\mathrm{C}} \\
\mathrm{l}_{\mathrm{C}}
\end{array}\right)
$$

\begin{tabular}{|r|r|}
\hline & \multicolumn{1}{|c|}{0} \\
\hline 0 & 181 \\
\hline 1 & 28.333 \\
\hline 2 & 400 \\
\hline 3 & 14.5 \\
\hline 4 & -0.384 \\
\hline 5 & 0.401 \\
\hline 6 & 3.787 \\
\hline 7 & $1.43 \cdot 10-3$ \\
\hline 8 & 0.066 \\
\hline 9 & 0.07 \\
\hline 10 & $4.26 \cdot 10^{4}$ \\
\hline 11 & 1.832 \\
\hline 12 & 1 \\
\hline 13 & 181 \\
\hline 14 & 348 \\
\hline 15 & 0.137 \\
\hline 16 & 0.165 \\
\hline 17 & 0.262 \\
\hline
\end{tabular}

Standard deviation for each variables:

$$
\mathrm{u}_{\mathrm{Z}}:=\left(\begin{array}{c}
0 \% \\
\mathrm{~N}_{\mathrm{e}} \cdot 1 \% \\
\mathrm{~T}_{\mathrm{W}} \cdot 2.5 \% \\
\mathrm{r}_{\mathrm{C}} \cdot 3.5 \% \\
1 \mathrm{deg} \\
1 \mathrm{deg} \\
1 \mathrm{deg} \\
\mathrm{mf}_{\mathrm{dot}} \cdot 1 \% \\
\mathrm{mair}_{\mathrm{dot}} \cdot 1 \% \\
\mathrm{FA}_{\mathrm{S}} \cdot 1 \% \\
\mathrm{LHV} \cdot 1 \% \\
\mathrm{a} \cdot 1 \% \\
\mathrm{n} \cdot 1 \% \\
\mathrm{P}_{1} \cdot 9 \% \\
\mathrm{~T}_{1} \cdot 1.3 \% \\
\mathrm{~b} \cdot 1 \% \\
\mathrm{~s}_{\mathrm{C}} \cdot 1 \% \\
\mathrm{l}_{\mathrm{C}} \cdot 1 \%
\end{array}\right)
$$

Program to find $\mathrm{dPd} \theta$ : 


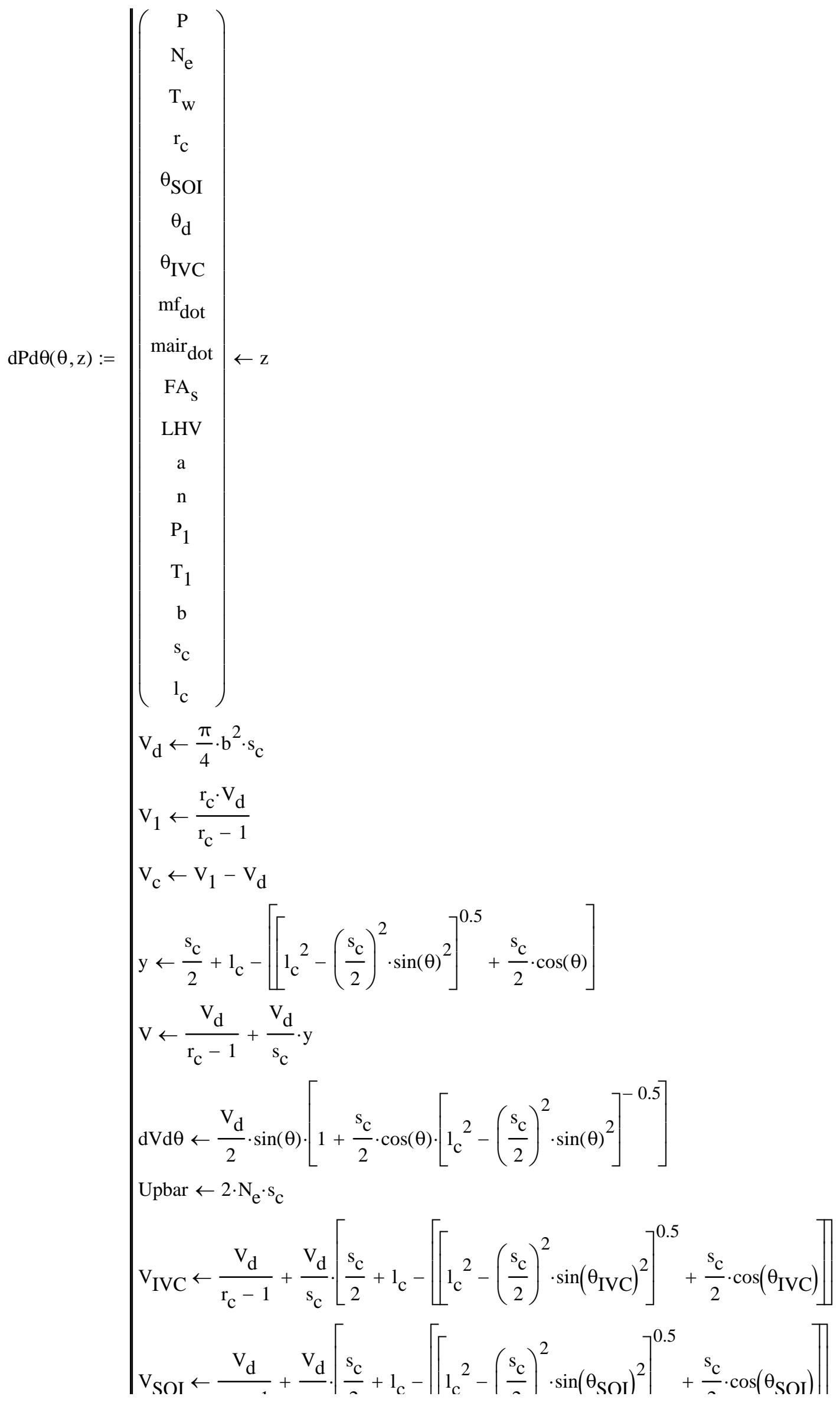




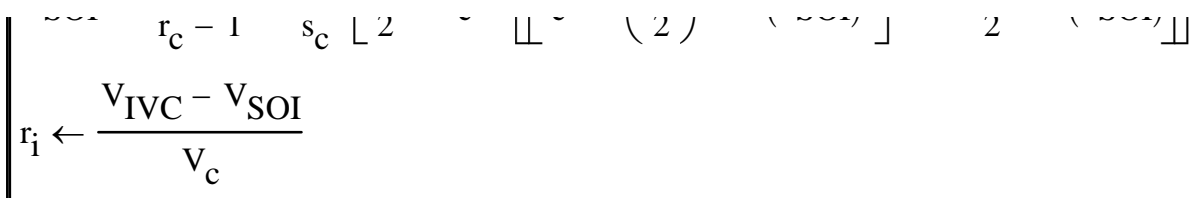

$$
\begin{aligned}
& \phi \leftarrow \frac{\mathrm{mf}_{\mathrm{dot}}}{\text { mair }_{\mathrm{dot}}} \cdot \frac{1}{\mathrm{FA}_{\mathrm{S}}} \\
& \mathrm{R} \leftarrow 0.287+0.02 \cdot \phi \\
& \mathrm{m}_{1} \leftarrow \frac{\mathrm{P}_{1} \cdot \mathrm{V}_{1}}{\mathrm{R} \cdot \mathrm{T}_{1}} \\
& \mathrm{~T} \leftarrow \frac{\mathrm{P} \cdot \mathrm{V}}{\mathrm{m}_{1} \cdot \mathrm{R}} \\
& \gamma \leftarrow \text { interp(cspline(xp, yp), xp, yp, } T \text { ) } \\
& \gamma_{\mathrm{T} 1} \leftarrow \text { interp }\left(\text { cspline(xp, yp), xp, yp, } \mathrm{T}_{1}\right) \\
& \mathrm{T}_{\mathrm{i}} \leftarrow \mathrm{T}_{1} \cdot \mathrm{r}_{\mathrm{i}}{ }_{\mathrm{T} 1^{-1}} \\
& \mathrm{P}_{\mathrm{i}} \leftarrow \mathrm{P}_{1} \cdot \mathrm{r}_{\mathrm{i}}^{\gamma_{\mathrm{T} 1}} \\
& \theta_{\text {id }} \leftarrow(0.36+0.22 \cdot \text { Upbar }) \cdot \exp \left[\left(\mathrm{E}_{\mathrm{a}} \cdot \frac{1}{\mathrm{R}_{\text {univ }} \cdot \mathrm{T}_{\mathrm{i}}}-\frac{1}{17190}\right) \cdot\left(\frac{21.2}{\frac{\mathrm{P}_{\mathrm{i}}}{100}-12.4}\right)^{0.63}\right] \cdot \mathrm{deg} \\
& \mathrm{x}_{\mathrm{b}} \leftarrow 1-\exp \left[-\mathrm{a} \cdot\left[\frac{\theta-\left(\theta_{\mathrm{SOI}}+\theta_{\mathrm{id}}\right)}{\theta_{\mathrm{d}}}\right]^{\mathrm{n}+1}\right] \\
& \mathrm{dxb}_{-} \mathrm{d} \theta \leftarrow \frac{(\mathrm{n}+1) \cdot \mathrm{a}}{\theta_{\mathrm{d}}} \cdot\left(1-\mathrm{x}_{\mathrm{b}}\right) \cdot\left[\frac{\theta-\left(\theta_{\text {SOI }}+\theta_{\mathrm{id}}\right)}{\theta_{\mathrm{d}}}\right]^{\mathrm{n}} \\
& \mathrm{Q}_{\text {in }} \leftarrow \mathrm{m}_{1} \cdot(1-\mathrm{f}) \cdot \frac{\phi \cdot \mathrm{FA}_{\mathrm{S}}}{1+\phi \cdot \mathrm{FA}_{\mathrm{S}}} \cdot \mathrm{LHV} \\
& \mathrm{dQc} \_\mathrm{d} \theta \leftarrow \mid \begin{array}{l}
\mathrm{Q}_{\mathrm{in}} \cdot \mathrm{dxb} \_\mathrm{d} \theta \text { if } \theta \geq \theta_{\text {SOI }}+\theta_{\text {id }} \\
0 \text { otherwise }
\end{array} \\
& \mathrm{P}_{\mathrm{m}} \leftarrow \mathrm{P}_{1} \cdot\left(\frac{\mathrm{V}_{1}}{\mathrm{~V}}\right)^{\gamma} \\
& \mathrm{U} \leftarrow \mid 2.28 \cdot \mathrm{Upbar}+3.24 \cdot 10^{-3} \cdot \mathrm{T}_{1} \cdot \frac{\mathrm{V}_{\mathrm{d}}}{\mathrm{V}_{1} \cdot \mathrm{P}_{1}} \cdot\left(\mathrm{P}_{1}-\mathrm{P}_{\mathrm{m}}\right) \text { if } \theta_{\mathrm{SOI}}<\theta<30 \mathrm{deg} \\
& \text { 2.28-Upbar otherwise } \\
& \mathrm{h}_{\mathrm{g}} \leftarrow 3.26 \cdot \mathrm{P}^{0.8} \cdot(|\mathrm{U}|)^{0.8} \cdot(\mathrm{b})^{-0.2} \cdot(\mathrm{T})^{-0.55} \cdot \frac{1}{1000} \\
& \mathrm{~A}_{\mathrm{w}} \leftarrow \pi \cdot \mathrm{b} \cdot \mathrm{y}+\frac{\pi}{2} \cdot \mathrm{b}^{2} \\
& h_{g} \cdot A_{w} \cdot\left(T-T_{w}\right)
\end{aligned}
$$




$$
\mid \begin{aligned}
& \operatorname{dQhtd} \theta \leftarrow \frac{\mathrm{N}}{N_{e}} \\
& \operatorname{dPd} \theta \leftarrow-\gamma \cdot \frac{P}{V} \cdot d V d \theta+\frac{\gamma-1}{V} \cdot d Q c \_d \theta-\left(\frac{\gamma-1}{V}\right) \cdot d Q h t d \theta
\end{aligned}
$$


Solving ODE to determine the pressure:

$$
\mathrm{D}(\theta, \mathrm{z}):=\left(\begin{array}{c}
\mathrm{dPd} \theta(\theta, \mathrm{z}) \\
0 \\
0 \\
0 \\
0 \\
0 \\
0 \\
0 \\
0 \\
0 \\
0 \\
0 \\
0 \\
0 \\
0 \\
0 \\
0 \\
0
\end{array}\right)
$$

$\mathrm{z}=\left(\begin{array}{c}\mathrm{P} \\ \mathrm{N}_{\mathrm{e}} \\ \mathrm{T}_{\mathrm{W}} \\ \mathrm{r}_{\mathrm{C}} \\ \theta_{\mathrm{SOI}} \\ \theta_{\mathrm{d}} \\ \theta_{\mathrm{IVC}} \\ \mathrm{mf}_{\mathrm{dot}} \\ \mathrm{mair}_{\mathrm{dot}} \\ \mathrm{FA}_{\mathrm{S}} \\ \mathrm{LHV} \\ \mathrm{a} \\ \mathrm{n} \\ \mathrm{P}_{1} \\ \mathrm{~T}_{1} \\ \mathrm{~b} \\ \mathrm{~s}_{\mathrm{C}} \\ \mathrm{l}_{\mathrm{C}}\end{array}\right) \quad\left(\begin{array}{cc}\mathrm{P} & 0 \\ \mathrm{~N}_{\mathrm{e}} & 1 \\ \mathrm{~T}_{\mathrm{W}} & 2 \\ \mathrm{r}_{\mathrm{C}} & 3 \\ \theta_{\mathrm{SOI}} & 4 \\ \theta_{\mathrm{d}} & 5 \\ \theta_{\mathrm{IVC}} & 6 \\ \mathrm{mf}_{\mathrm{dot}} & 7 \\ \mathrm{mair}_{\mathrm{dot}} & 8 \\ \mathrm{FA}_{\mathrm{S}} & 9 \\ \mathrm{LHV} & 10 \\ \mathrm{a} & 11 \\ \mathrm{n}_{1} & 12 \\ \mathrm{P}_{1} & 13 \\ \mathrm{~T}_{1} & 14 \\ \mathrm{~b} & 15 \\ \mathrm{~s}_{\mathrm{C}} & 16 \\ \mathrm{l}_{\mathrm{C}} & 17\end{array}\right)$

$$
\begin{aligned}
& \text { Soln }:=\operatorname{rkfixed}\left(\mathrm{z}_{\text {initial }},-180 \mathrm{deg}, 180 \cdot \operatorname{deg}, 360, \mathrm{D}\right) \\
& \theta:=\operatorname{Soln}^{\langle 0\rangle} \cdot \frac{360}{2 \pi} \quad \mathrm{P}:=\operatorname{Soln}^{\langle 1\rangle}
\end{aligned}
$$

Determining sensitivities for each variables:

$$
\operatorname{Sen}(\mathrm{z} 1):=\left\{\begin{array}{l}
\text { for } \mathrm{i} \in 0 \text {.. last }(\mathrm{z}) \\
\begin{array}{l}
\Delta \mathrm{z} \leftarrow 0 \cdot \mathrm{z} 1 \\
\Delta \mathrm{z}_{\mathrm{i}} \leftarrow \mathrm{z} 1_{\mathrm{i}} \\
\mathrm{S} 1 \leftarrow \operatorname{rkfixed}\left(\mathrm{z}_{\text {initial }}+\Delta \mathrm{z},-180 \mathrm{deg}, 180 \cdot \mathrm{deg}, 360, \mathrm{D}\right)^{\langle 1\rangle} \\
\left.\mathrm{S} 2 \leftarrow \operatorname{rkfixed}\left(\mathrm{z}_{\text {initial }}-\Delta \mathrm{z},-180 \mathrm{deg}, 180 \cdot \mathrm{deg}, 360, \mathrm{D}\right)\right)^{\langle 1\rangle} \\
\text { Sen } \left.{ }_{\mathrm{i}}\right\rangle \leftarrow \frac{\mathrm{S} 1-\mathrm{S} 2}{2 \cdot \Delta \mathrm{z}_{\mathrm{i}}}
\end{array}
\end{array}\right.
$$


Sensitivity $_{\mathrm{u}}:=\operatorname{Sen}\left(\mathrm{u}_{\mathrm{z}}\right)$

$$
\begin{aligned}
& \mathrm{i}:=1 . . \operatorname{last}(\mathrm{z}) \quad \mathrm{O}_{\mathrm{z}}{ }_{\mathrm{i}\rangle}{ }:=\left(\text { Sensitivity }_{\mathrm{u}}\langle\mathrm{i}\rangle\right)^{2} \cdot\left(\mathrm{u}_{\mathrm{z}_{\mathrm{i}}}\right)^{2} \\
& \text { Uncertainty: } \quad \mathrm{U}_{\mathrm{P}}:=\sqrt{\left.\sum_{\mathrm{i}=0}^{\text {last }(\mathrm{z})} \mathrm{O}_{\mathrm{z}}^{\langle i}\right\rangle}
\end{aligned}
$$

Uncertainty Percentage Contribution: $\quad \mathrm{UPC}^{\langle i\rangle}:=\frac{\left.\mathrm{O}_{\mathrm{z}}^{\langle i}\right\rangle}{\mathrm{U}_{\mathrm{P}}^{2}}$

Uncertainty Magnification Factors: $\quad \mathrm{UMF}^{\langle i\rangle}:=\overline{\left(\frac{\mathrm{z}_{\mathrm{i}}}{\mathrm{P}} \cdot \sqrt{\mathrm{O}_{\mathrm{z}}^{\langle\mathrm{i}}}\right)}$

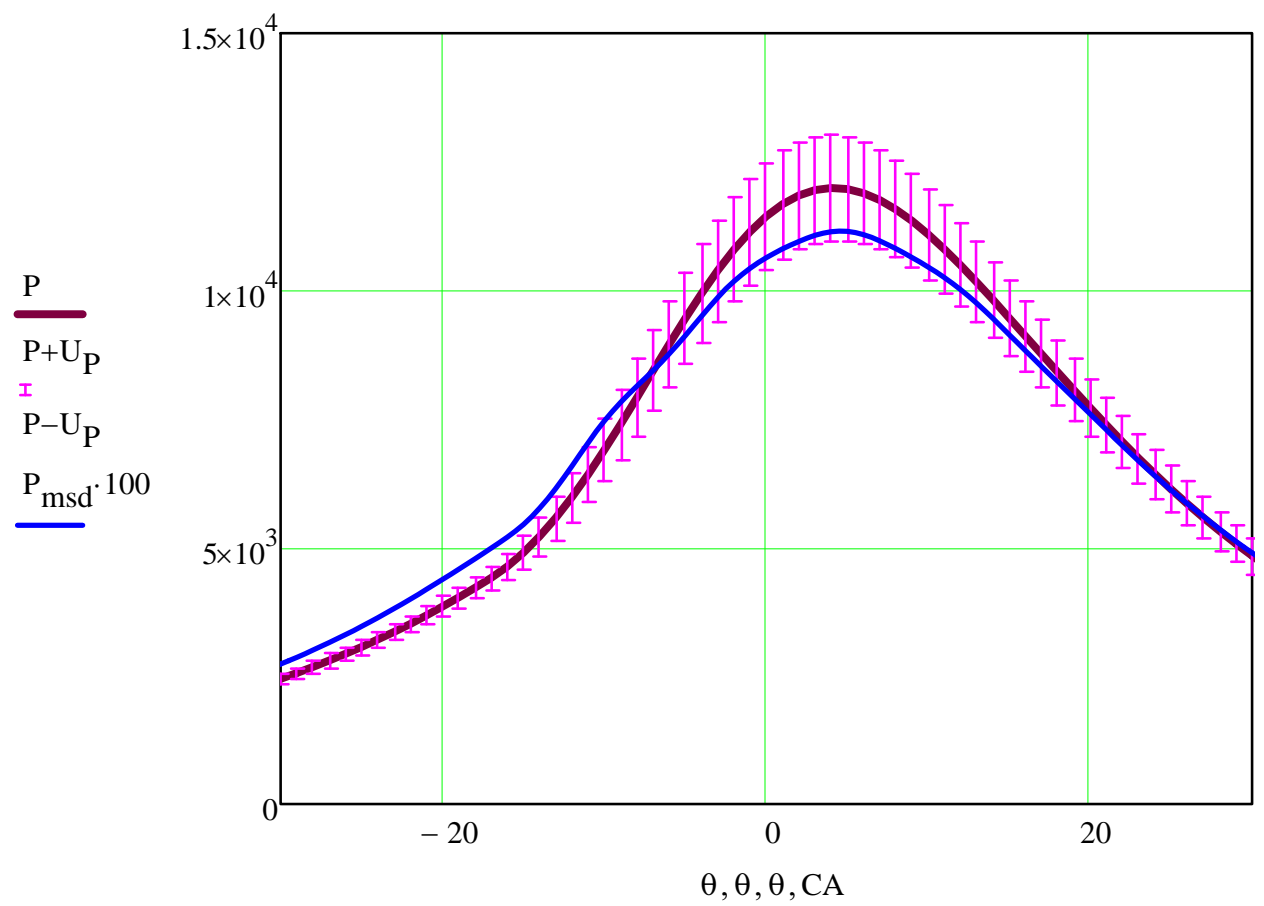




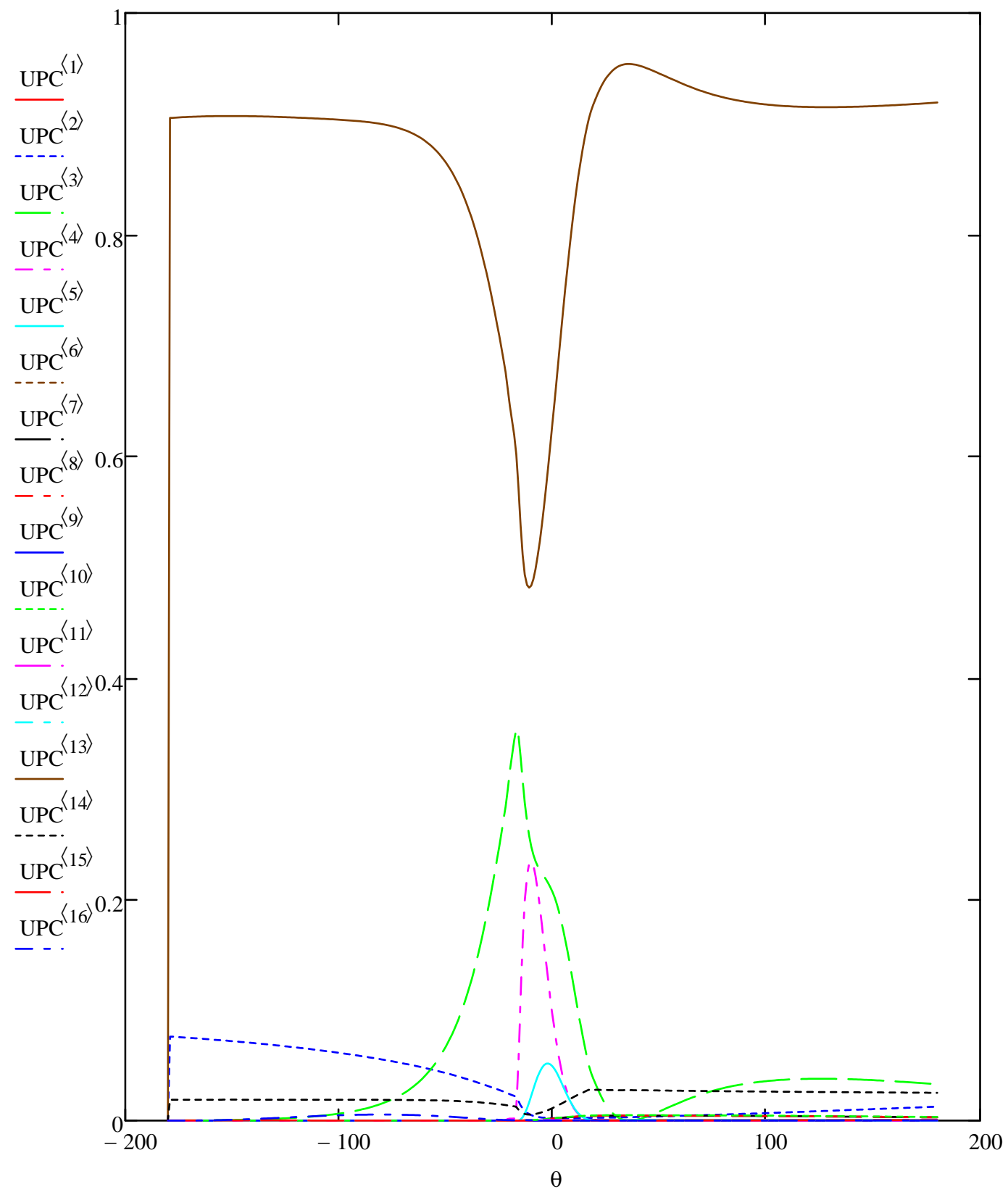

$\left(\begin{array}{cc}\mathrm{P} & 0 \\ \mathrm{~N}_{\mathrm{e}} & 1 \\ \mathrm{~T}_{\mathrm{w}} & 2 \\ \mathrm{r}_{\mathrm{C}} & 3 \\ \theta_{\mathrm{SOI}} & 4 \\ \theta_{\mathrm{d}} & 5 \\ \theta_{\mathrm{IVC}} & 6 \\ \mathrm{mf}_{\mathrm{dot}} & 7 \\ \mathrm{mair}_{\mathrm{dot}} & 8 \\ \mathrm{FA}_{\mathrm{S}} & 9 \\ \mathrm{LHV} & 10 \\ \mathrm{a} & 11 \\ \mathrm{n} & 12 \\ \mathrm{P}_{1} & 13 \\ \mathrm{~T} 1 & 14 \\ \mathrm{~b} & 15 \\ \mathrm{~s}_{\mathrm{C}} & 16 \\ \mathrm{l}_{\mathrm{C}} & 17\end{array}\right)$




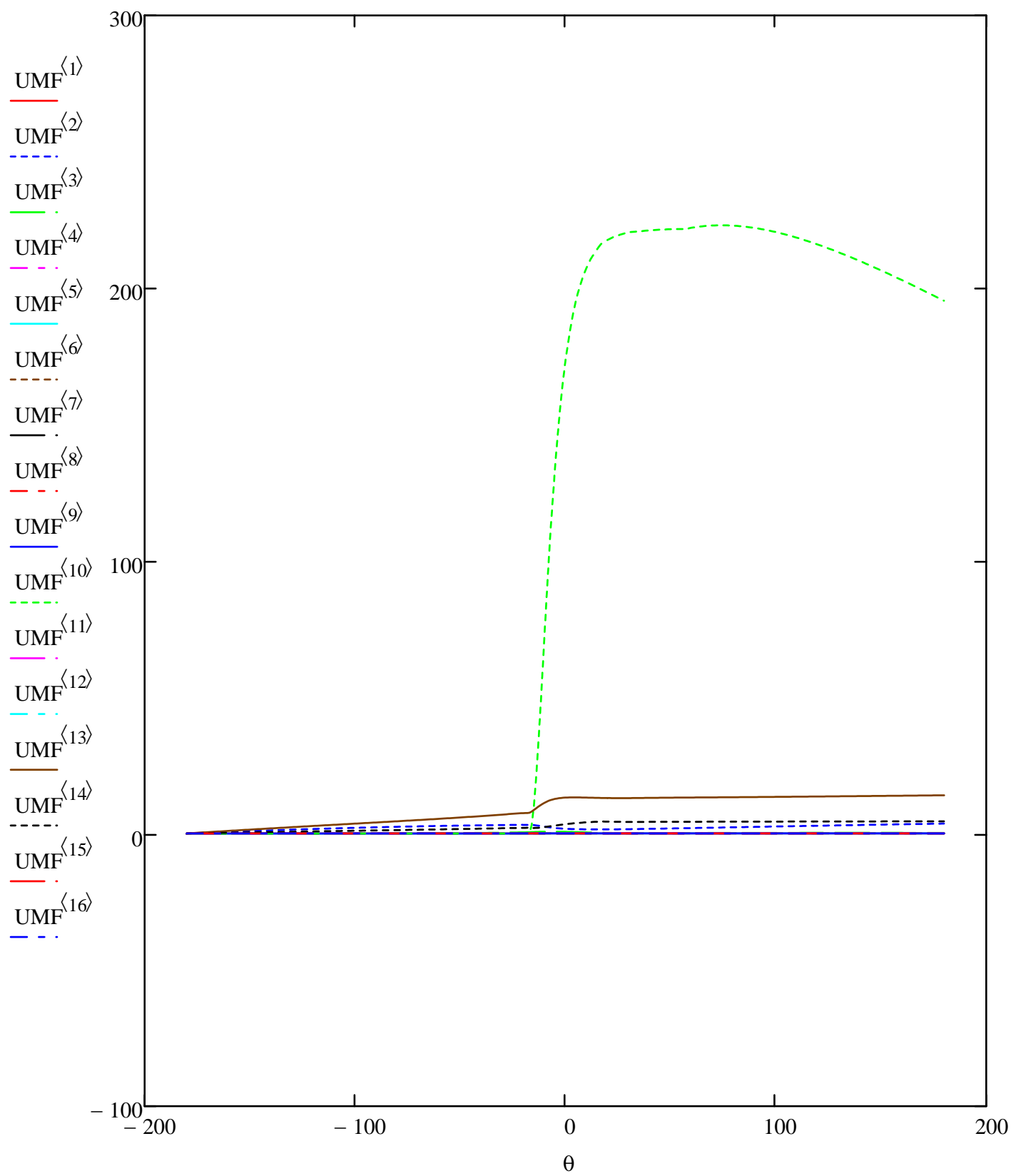

$\mathrm{z}_{1}:=\mathrm{z} \cdot 1 \% \quad \mathrm{z}_{2}:=\mathrm{z} \cdot 10 \%$

$\mathrm{i}:=0$.. last( $\mathrm{z})$

Sen $_{\text {normalized }}\left\langle\mathrm{i}_{\rangle}\right\rangle=\frac{\operatorname{Sen}\left(\mathrm{z}_{1}\right)^{\langle\mathrm{i}\rangle}}{\mathrm{P}}$ 


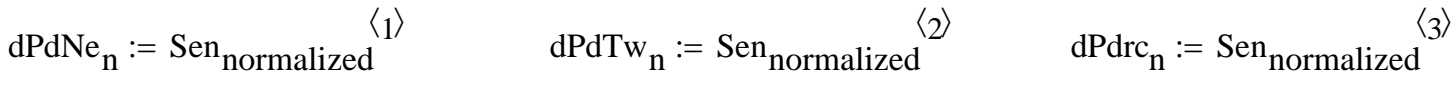

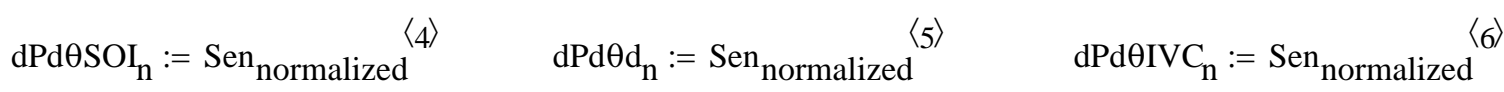

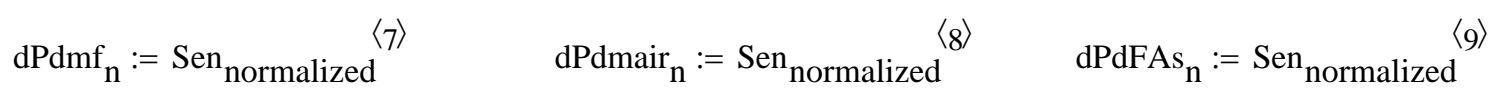

$$
\begin{aligned}
& \mathrm{dPdLHV}_{\mathrm{n}}:=\text { Sen }_{\text {normalized }}^{\langle 10\rangle} \quad \mathrm{dPda}_{\mathrm{n}}:=\text { Sen }_{\text {normalized }}^{\langle 11\rangle} \quad \mathrm{dPdn}_{\mathrm{n}}:=\text { Sen }_{\text {normalized }}\langle 12\rangle \\
& \mathrm{dPdP}_{\mathrm{n}}:=\text { Sen }_{\text {normalized }}^{\langle 13\rangle} \quad \mathrm{dPdT}_{\mathrm{n}}:=\text { Sen }_{\text {normalized }}\langle 14\rangle \quad \mathrm{dPdb}_{\mathrm{n}}:=\text { Sen }_{\text {normalized }}\langle 15\rangle \\
& \mathrm{dPdsc}_{\mathrm{n}}:=\operatorname{Sen}_{\text {normalized }}\langle 16\rangle \quad \operatorname{dPdlc}_{\mathrm{n}}:=\text { Sen }_{\text {normalized }}\langle 17\rangle
\end{aligned}
$$




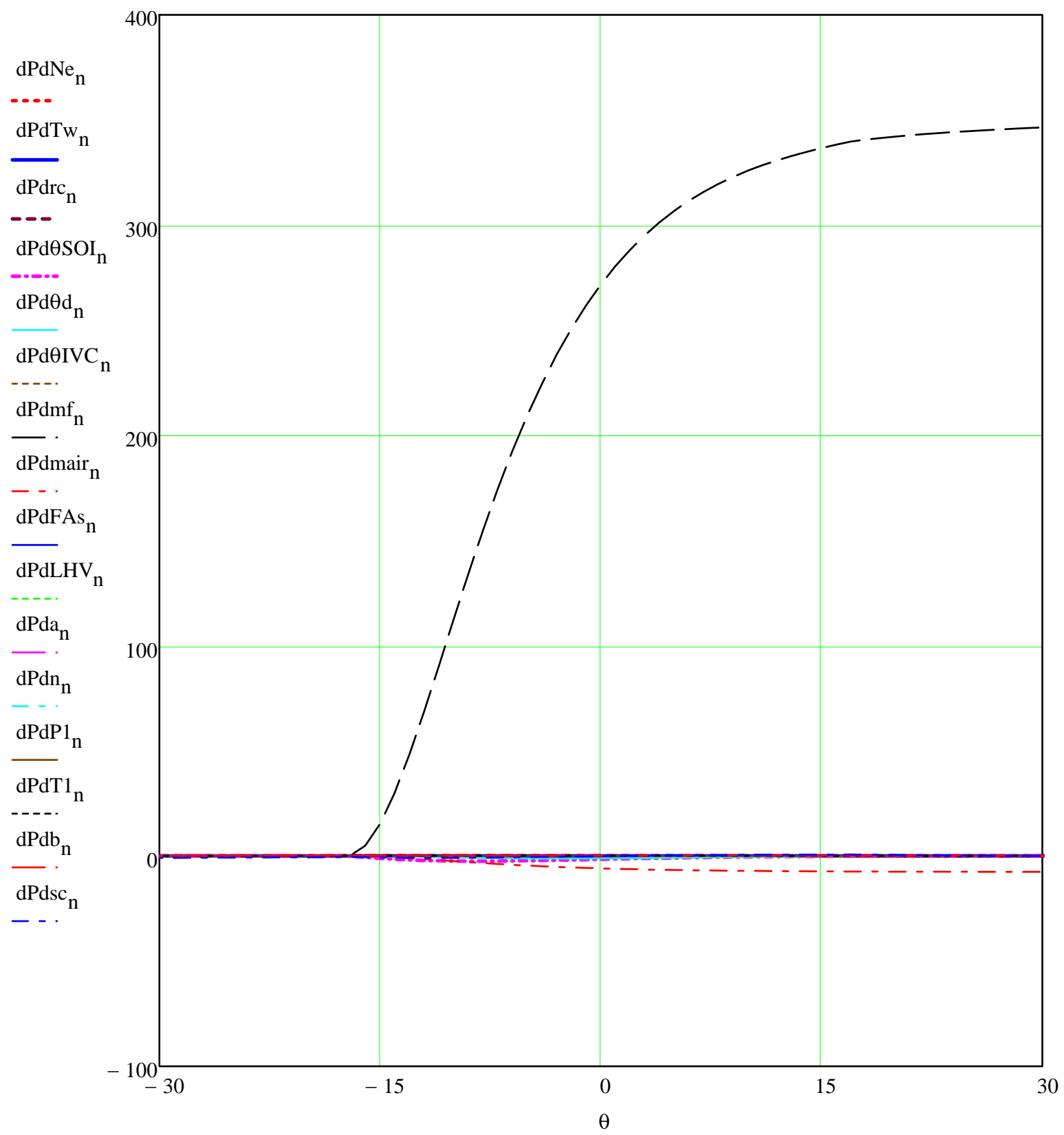




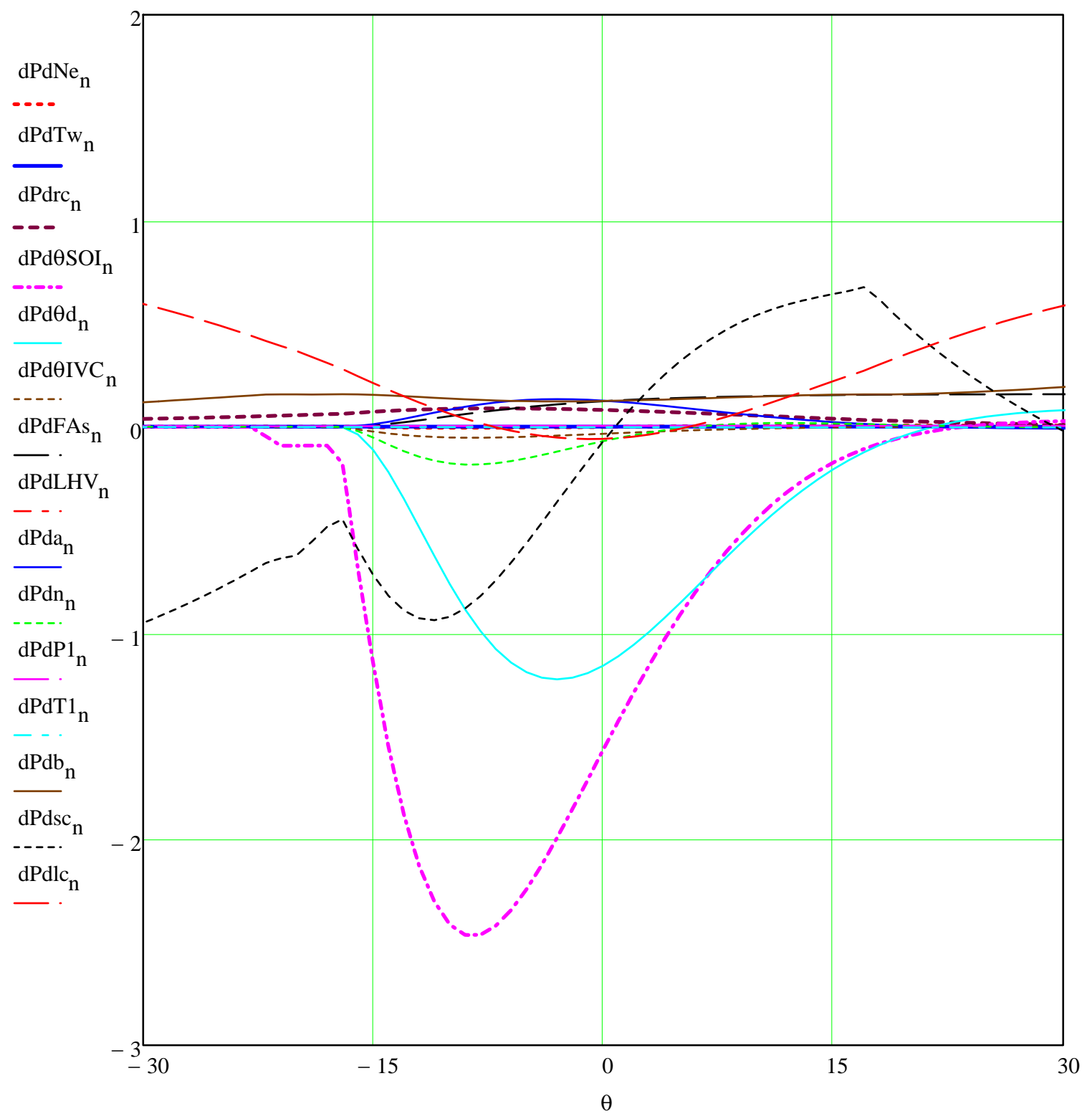




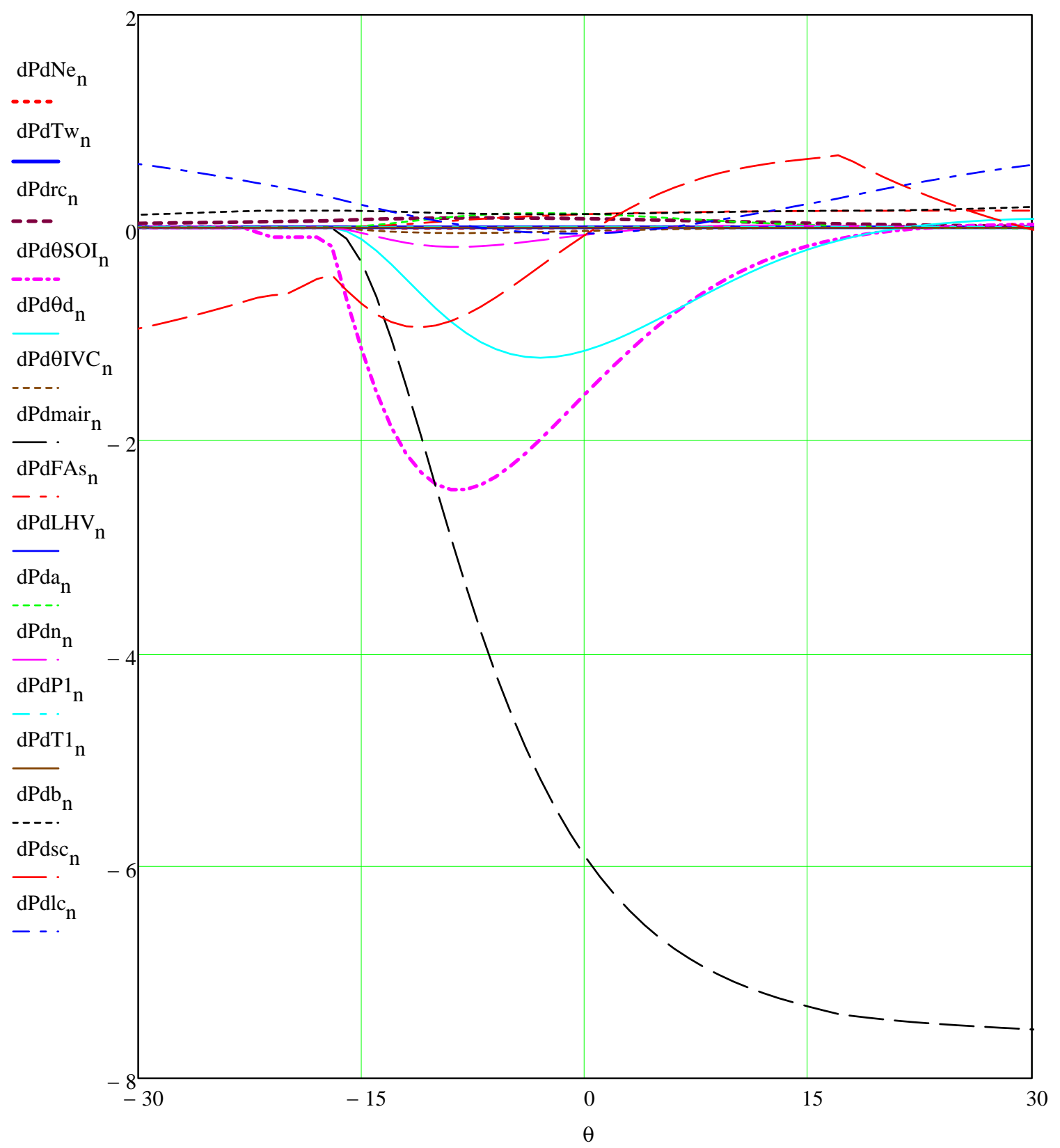


Sensitivity $:=\operatorname{Sen}\left(z_{1}\right) \quad$ Sensitivity $_{d}:=\operatorname{Sen}\left(z_{2}\right)$

$\mathrm{dPdNe}:=$ Sensitivity $\left.{ }^{\langle}\right\rangle \quad \mathrm{dPdNe} 2:=$ Sensitivity $_{\mathrm{d}}\left\langle{ }_{1}\right\rangle \quad \mathrm{dPdTw}:=$ Sensitivity $\left.{ }_{2}\right\rangle \quad \operatorname{dPdTw} 2:=$ Sensitivity $_{\mathrm{d}}\left\langle{ }^{2}\right\rangle$

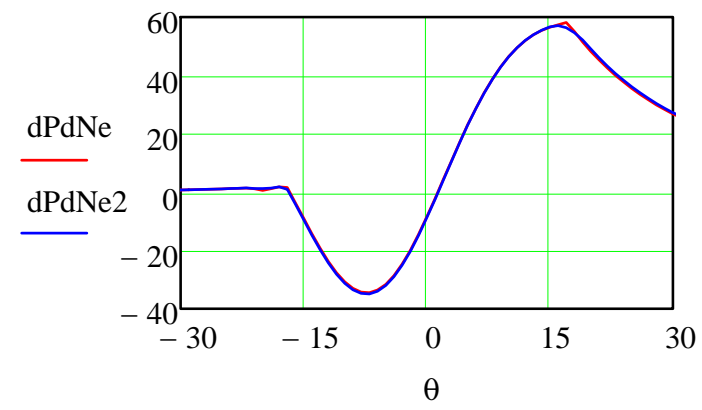

dPdrc := Sensitivity ${ }^{\langle 3\rangle} \quad$ dPdrc2 $:=$ Sensitivity $_{\mathrm{d}}\langle 3\rangle$

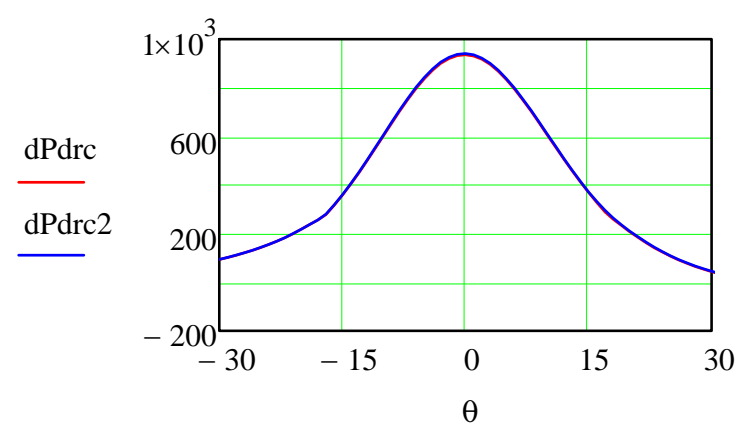

$\mathrm{dPd} \theta \mathrm{d}:=$ Sensitivity $^{\langle 5\rangle} \mathrm{dPd} \theta \mathrm{d} 2:=$ Sensitivity $_{\mathrm{d}}\langle 5\rangle$

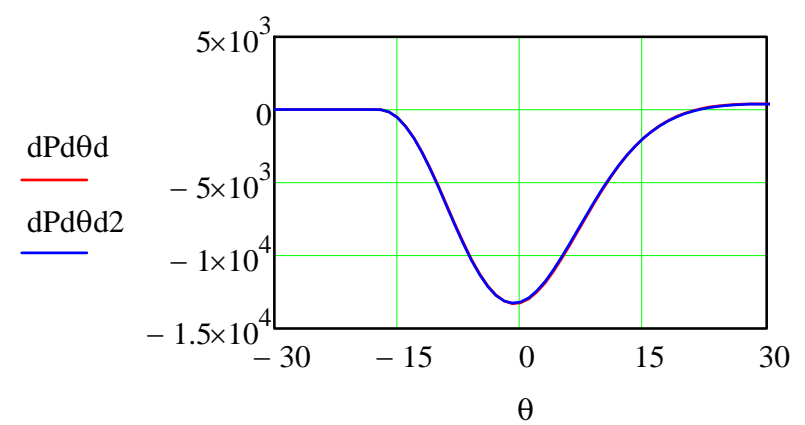

$\operatorname{dPdmf}:=$ Sensitivity $^{\langle 7\rangle} \operatorname{dPdmf} 2:=$ Sensitivity $\left._{\mathrm{d}}{ }{ }\right\rangle$

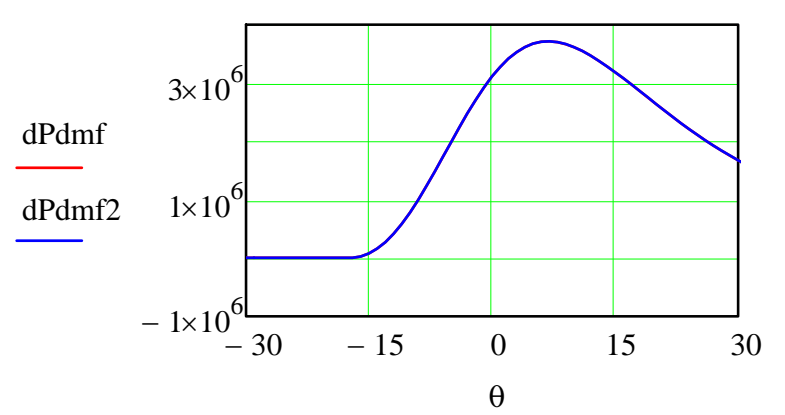

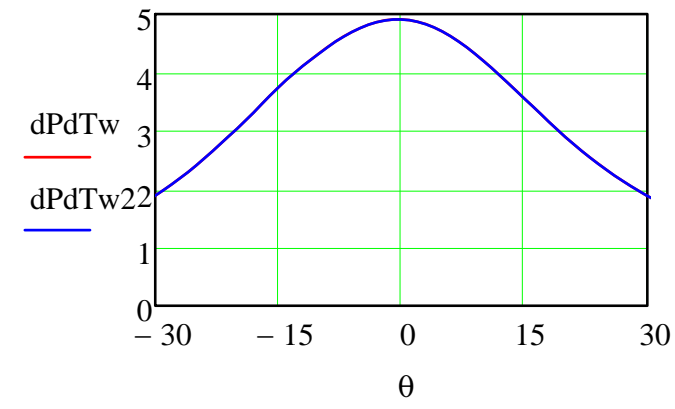

$\operatorname{dPd} \theta$ SOI $:=$ Sensitivity $^{\langle 4\rangle} \operatorname{dPd} \theta$ SOI2 $:=$ Sensitivity $_{\mathrm{d}}\langle 4\rangle$

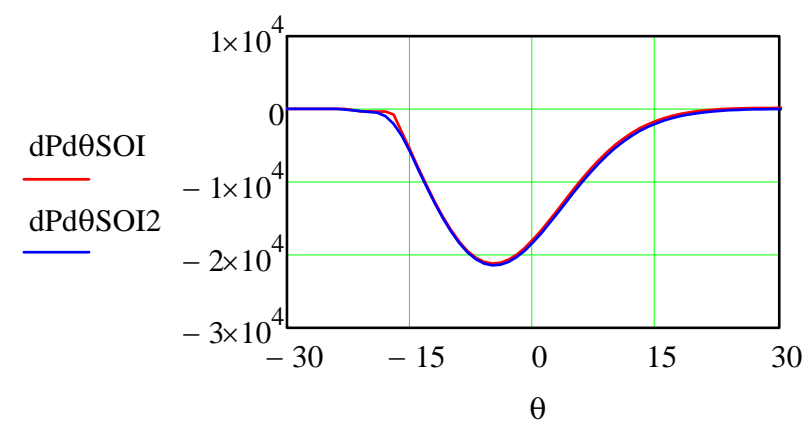

$\operatorname{dPd} \theta I V C:=$ Sensitivity $^{\langle{ }\rangle} \operatorname{dPd} \theta$ IVC2 $:=$ Sensitivity $_{\mathrm{d}}\langle{ }\rangle$

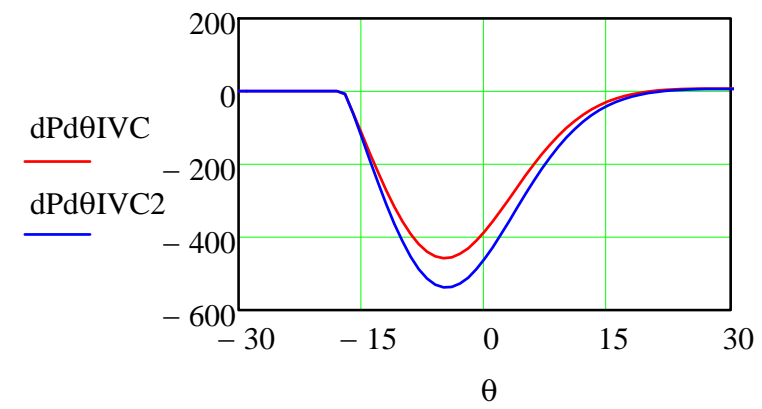

$\operatorname{dPdmair}:=$ Sensitivity $^{\langle{ }\rangle} \quad \mathrm{dPdmair}:=$ Sensitivity $_{\mathrm{d}}\langle 8\rangle$

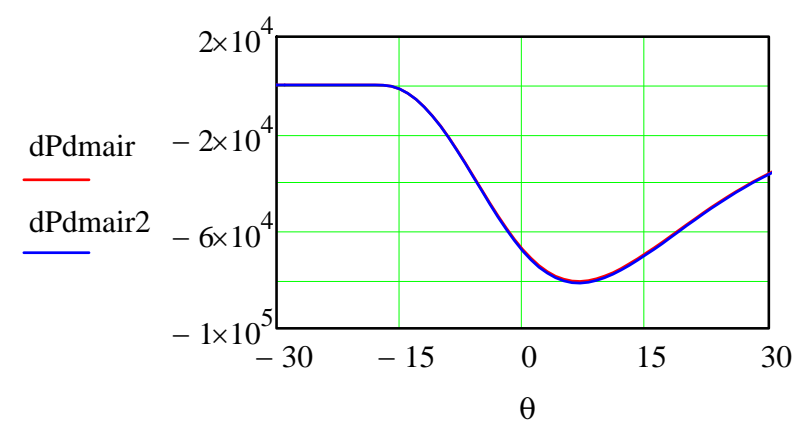


dPdFAs $:=$ Sensitivity $^{\langle 9\rangle}$ dPdFAs2 $:=$ Sensitivity $_{d}\langle 9\rangle$

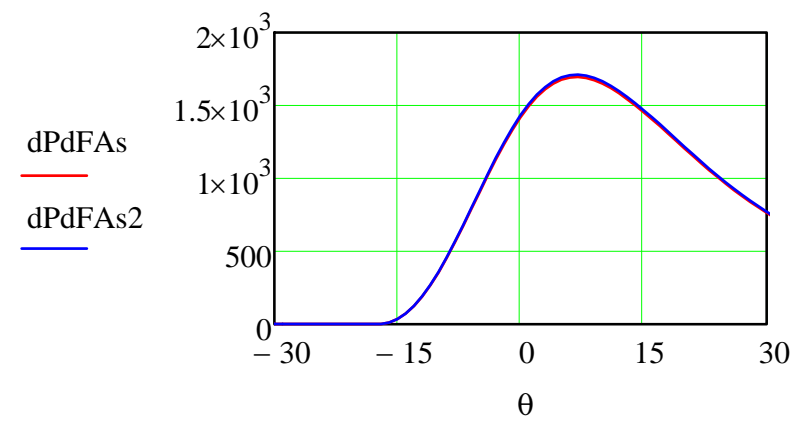

$\mathrm{dPda}:=$ Sensitivity ${ }^{\langle 11\rangle} \quad \mathrm{dPda} 2:=$ Sensitivity $_{\mathrm{d}}\langle 11\rangle$

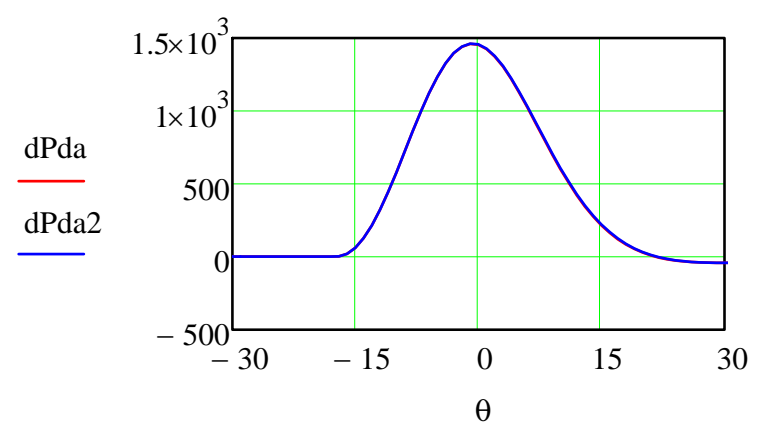

$\mathrm{dPdP} 1:=$ Sensitivity ${ }^{\langle 3\rangle} \quad \mathrm{dPdP} 12:=$ Sensitivity $_{\mathrm{d}}\langle 13\rangle$

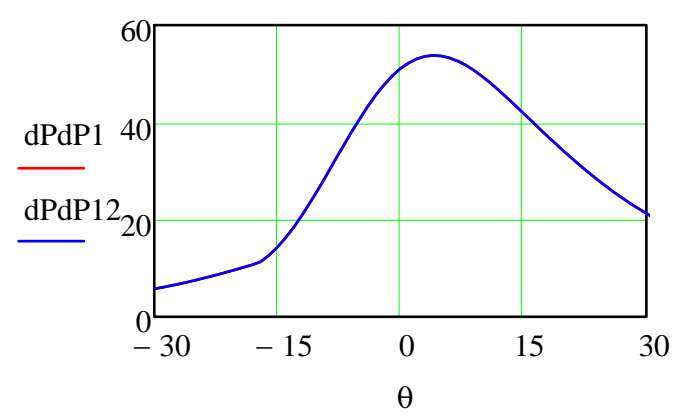

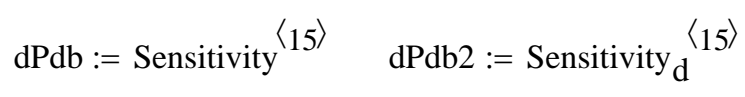

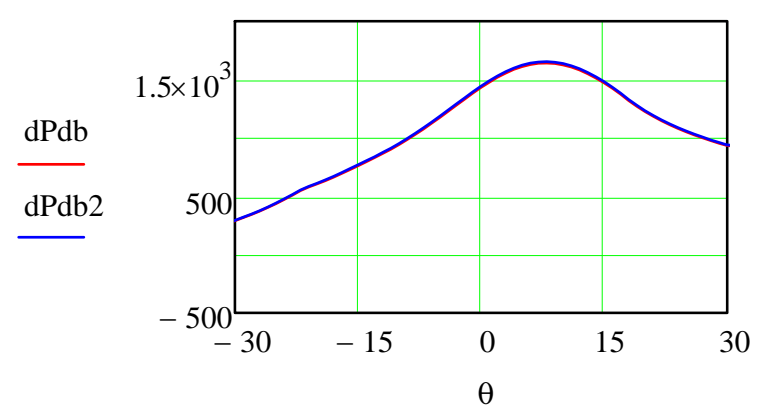

dPdLHV $:=$ Sensitivity ${ }^{\langle 0\rangle}$ dPdLHV2 $:=$ Sensitivity $_{\mathrm{d}}\langle 10\rangle$

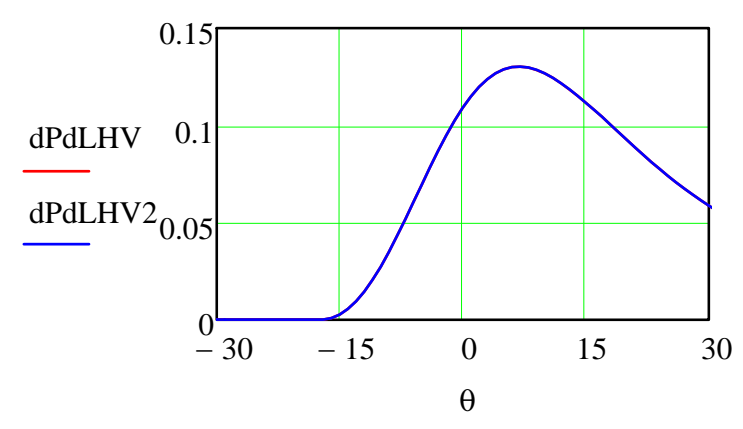

$\operatorname{dPdn}:=$ Sensitivity $^{\langle 12\rangle} \operatorname{dPdn} 2:=$ Sensitivity $_{\mathrm{d}}\langle 12\rangle$

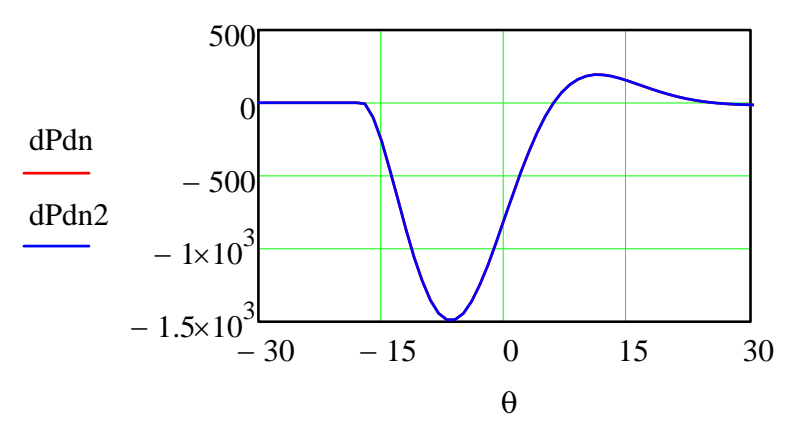

$\operatorname{dPdT} 1:=$ Sensitivity $^{\langle 14\rangle} \quad \mathrm{dPdT}_{2}:=$ Sensitivity $_{\mathrm{d}}\langle 14\rangle$

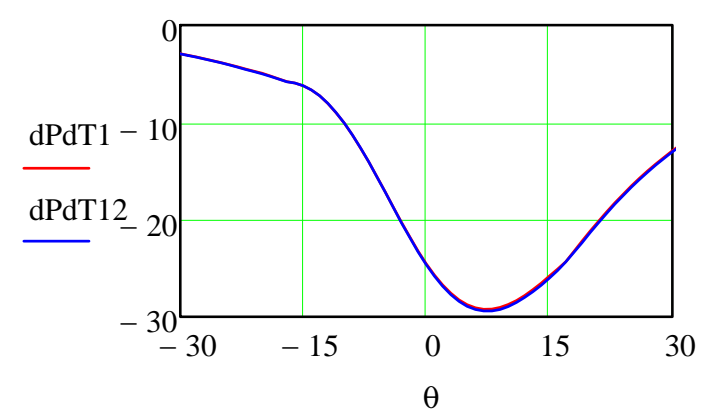

dPdsc $:=$ Sensitivity $^{\langle 16\rangle} \quad \mathrm{dPdsc}:=$ Sensitivity $_{\mathrm{d}}\left\langle{ }_{16}\right\rangle$

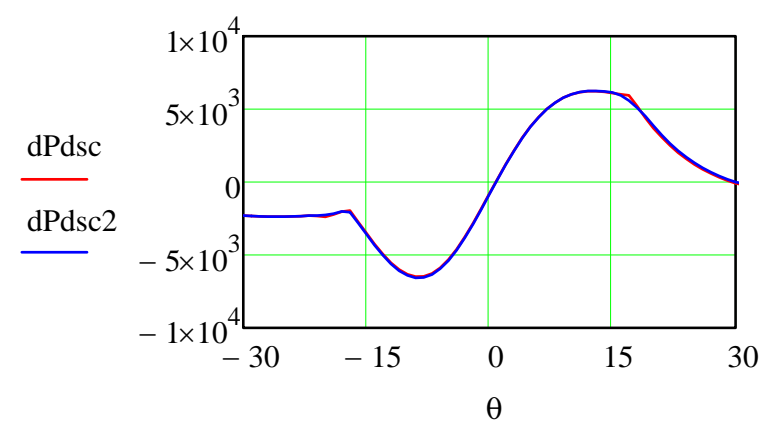




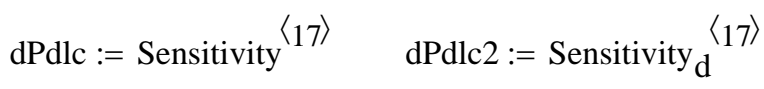

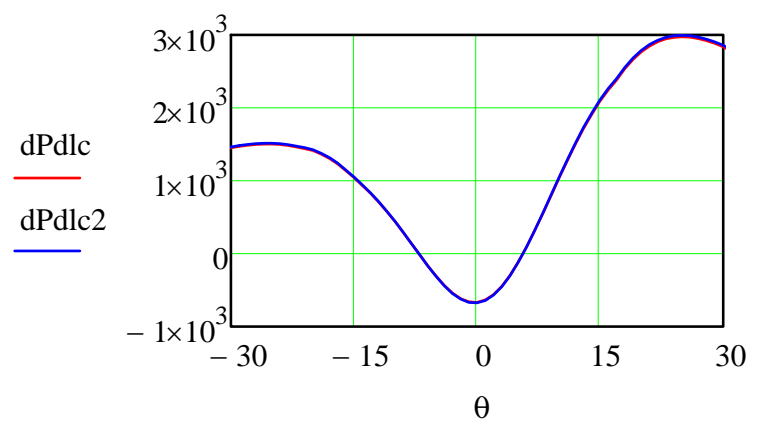




$\left(\begin{array}{cc}\mathrm{P} & 0 \\ \mathrm{~N}_{\mathrm{e}} & 1 \\ \mathrm{~T}_{\mathrm{W}} & 2 \\ \mathrm{r}_{\mathrm{C}} & 3 \\ \theta_{\mathrm{SOI}} & 4 \\ \theta_{\mathrm{d}} & 5 \\ \theta_{\mathrm{IVC}} & 6 \\ \mathrm{mf}_{\mathrm{dot}} & 7 \\ \mathrm{mair}_{\mathrm{dot}} & 8 \\ \phi & 9 \\ \mathrm{LHV}^{\mathrm{L}} & 10 \\ \mathrm{a} & 11 \\ \mathrm{n} & 12 \\ \mathrm{P}_{1} & 13 \\ \mathrm{~T} 1 & 14 \\ \mathrm{~b} & 15 \\ \mathrm{~s}_{\mathrm{C}} & 16 \\ \mathrm{l}_{\mathrm{C}} & 17\end{array}\right)$

